\section{"Wth National Libraiy \\ of Canada}

Canadian Theses Service

Ottawa, Canada

K1A ON4
Bibliothèque nationale

du Canada

Service des thèses canadiennes

\section{NOTICE}

The quality of this microform is heavily dependent upon the quality of the original thesis submitted for microfilming. Every effort has been made to ensure the highest quality of reproduction possible.

If pages are missing, contact the university which granted the degree.

Some pages may have indistinct print especially if the original pages were typed with a poor typewriter ribbon or if the university sent us an inferior photocopy.

Reproduction in full or in part of this microform is governed by the Canadian Copyright Act, R.S.C. 1970, c. C-30, and subsequent amendments.

\begin{abstract}
AVIS
La qualité de celte microforme dépend grandement de la qualité de la thèse soumise au microfilmage. Nous avons tout fait pour assurer une qualité supérieure de reproduction.

S'il manque des pages, veuillez communiquer avec l'université qui a conféré le grade.

La qualité d'impression de certaines pages peut laisser à désirer, surtout si les pages originales ont été dactylographiées à l'aide d'un ruban usé ou si l'université nous a fait parvenir une photocopie de qualité intérieure.
\end{abstract}

La reproduction, méme partielle, de cette microforme est soumise à la Loi canadienne sur le droit d'auteur, SRC 1970 , c. C-30, et ses amendements subséquents. 


\title{
Strontium Extraction by Aluminothermic Reduction
}

by

\author{
Joseph Langlais
}

A Thesis submitted to the Faculty of Graduate Studies in partial fulfilment

of the requirements of the degree of Master of Engineering

Department of Mining and Metallurgical Engineering

McGill University, Montreal, Canada

CJoseph Langlais, April 1991 
National Library

of Canada

Bibliothèque nationale

du Canada

Canadian Theses Service

Service des thèses canadiennes

Ottawa, Canada

K1A ONA

The author has granted an irrevocable nonexclusive licence allowing the National Library of Canada to reproduce, loan, distribute or sell copies of his/her thesis by any means and in any form or format, making this thesis available to interested persons.

The author retains ownership of the copyright in his/her thesis. Neither the thesis nor substantial extracts from it may be printed or otherwise reproduced without his/her permission.
L'auteur a accordé une licence irrévocable et non exclusive permettant à la Bibliothèque nationale du Canada de reproduire, prêter. distribuer ou vendre des copies de sa thèse de quelque manière et sous quelque forme que ce soit pour mettre des exemplaires de cette thèse à la disposition des personnes intéressées.

L'auteur conserve la propriété du droit d'auteur qui protège sa thèse. Ni la thèse ni des extraits substantiels de celle-ci ne doivent être imprimés ou autrement reproduits sans son autorisation. 
... et les souvenirs se perdront dans l'oublie comme une larme dans la pluie ...

the author 


\section{RÉSUMÉ}

Un procédé de réduction métallo-thermique communément appelé "Fusion-LixiviationEvaporation" est sous développement pour l'extraction du strontium et d'autres métaux du Groupe IA ou IIA. Le métal à extraire est réduit et lixivié à partir du minérai ou du concentré par un excès de métal liquide agissant comme réducteur. Lors du procédé, le métal d'interêt extrait du matériel mère sera dissous dans l'excès de solvent métallique puis subséquemment sera extrait sous forme de vapeur par distillation sous vide. Le métal sera condensé et récupéré à l'état métallique.

Un programme expérimental comportant huit expériences a été conduit. La procédure expérimentale consistait à fondre l'aluminium réducteur dans un creuset d'alumine et d'ajouter les réactifs (e.g., $\mathrm{SrCO}_{3}, \mathrm{Mg}$ ou $\mathrm{Bi}$ ). Ces derniers étaient mélangés à l'aide d'un agitateur sous un atmosphère d'argon pour minimizer l'oxidation. L'interprétation de la cinétique impliquait un échantillonnage à toutes les 20 minutes. Les expériences furent conduites sous les mêmes conditions: température $\left(1000^{\circ} \mathrm{C}\right)$, pression $(1 \mathrm{~atm}$.), agitation, masses des réactants, atmosphère d'argon et temps (1 heure).

Le programme expérimental était divisé en deux étapes dont la première consistait à varier le ratio molaire Magnésium/Strontium de 1 à 10 et d'en observer les effets sur le recouvrement du strontium dans la phase liquide. Le magnesium avait pour effet de diminuer la tension de surface de l'aluminium liquide et d'augmenter son affinité pour l'oxygène. La seconde étape consistait à ajouter du bismuth à l'aluminium pour diminuer la tension de surface, sans toutefois altérer son affinité pour l'oxygène. Il a été trouvé que le recouvrement de strontium dans le lingot métallique augmentait avec l'addition de magnésium ce qui n'était pas le cas avec l'ajout de bismuth. Les resultats ont démontrés un recouvrement de strontium de $51.3 \%$ pour un ratio molaire de 10Mg:Sr. 


\section{$\underline{\text { ABSTRACT }}$}

The Melt-Leach-Evaporation (MLE) process is under developement for the extraction of valuable Group IA or IIA metals of the Periodic Table, such as lithium, calcium, magnesium and strontium. The process consists of mixing and contacting the value metal source material, which might be an ore or concentrate, with an excess of molten metal which is acting as a reductant and lixiviant. In the process, the value metal extracted from the source material is dissolved in the excess molten metallic solvent and is subsequently extracted as a vapour by vacuum distillation. The vapour is condensed and recuperated in the metallic state.

An experimental program involving eight experiments was carried out. The experimental procedure consisted in essence of melting the aluminum reductant in a crucible and adding the source material, $\mathrm{SrCO}_{3}$, and other reactant $(\mathrm{Mg}$ or $\mathrm{Bi})$. The reactants were mixed together by an impeller and were held under an argon atmosphere to minimize oxidation. Samples were taken every twenty minutes for kinetic analysis. The experiments were carried out under the same conditions of temperature $\left(1000^{\circ} \mathrm{C}\right)$, pressure $(1 \mathrm{~atm}$.), stirring intensity, reactant masses, argon atmosphere and time (1 hour).

The experimental program was divided into two parts. The first part was concerned with the effect of changing the $\mathrm{Mg}: \mathrm{Sr}$ molar ratio on the recovery of strontium into the molten phase. Magnesium was added to the melt to lower the surface tension of aluminum and to increase the oxygen affinity of the melt. The second part investigated the effect of lowering the surface tension, without altering the oxygen affinity, on strontium recovery. In the second set of experiments, bismuth was added to the melt to lower the surface tension. The strontium recovery to the metal ingot was found to increase with magnesium addition. This was not observed with Bi addition. The results showed a strontium recovery of $51.3 \%$ at $10 \mathrm{Mg}: \mathrm{Sr}$ molar ratio. 


\section{ACKNOLEDGEMENTS}

The author wishes to express his deepest gratitude to his research director, Professor Ralph Harris, for his guidance, valuable suggestions, constant encouragement, freedom and his advice during the course of this investigation and during the preparation and writing of this thesis.

Thanks to all students and staff members of the Department of Mining and Metallurgical Engineering at McGill University for their assistance, patience and encouragement throughout this research program.

The author would also like to thank all members of Dr. Harris' group: Robert Selby, Zhou Wang, Liu Jin and the foundry laboratory technician, Robert Paquette, for their helpful assistance in all aspects of the project.

I would like to thank my family for their love and infinite generosity.

A special thank you to my wife, Johanne, for her love, emotional support, encouragement and outstanding patience. 


\section{TABLE OF CONTENTS}

I. INTRODUCTION $\ldots \ldots \ldots \ldots \ldots \ldots \ldots \ldots \ldots \ldots \ldots \ldots \ldots \ldots \ldots \ldots$

I.1 MELT-LEACH-EVAPORATION PROCESS $\ldots \ldots \ldots \ldots \ldots \ldots \ldots 1$

1.2.1 THE METAL STRONTIUM $\ldots \ldots \ldots \ldots \ldots \ldots \ldots \ldots \ldots \ldots \ldots \ldots \ldots \ldots$

I.2.2 THE ELEMENT STRONTIUM $\ldots \ldots \ldots \ldots \ldots \ldots \ldots \ldots \ldots \ldots 4$

I.2.3 STRONTIUM OCCURRENCE $\ldots \ldots \ldots \ldots \ldots \ldots \ldots \ldots \ldots \ldots$

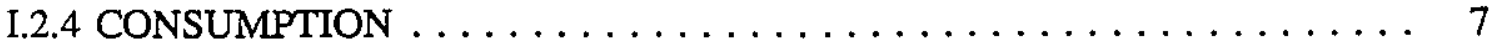

I.3 CHARACTERISTICS AND USES OF STRONTIUM $\ldots \ldots \ldots \ldots \ldots 10$

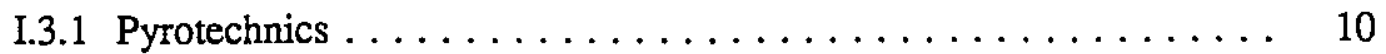

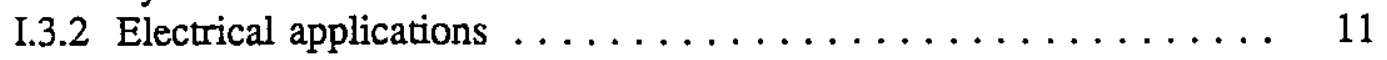

I.3.3 Glass and Ceramics Industries $\ldots \ldots \ldots \ldots \ldots \ldots \ldots \ldots \ldots$

I.3.4 Paints and Rubber Industries $\ldots \ldots \ldots \ldots \ldots \ldots \ldots \ldots \ldots$

I.3.5 Metallurgical Industries $\ldots \ldots \ldots \ldots \ldots \ldots \ldots \ldots \ldots, 12$

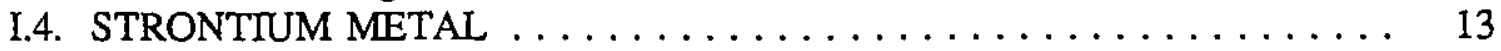

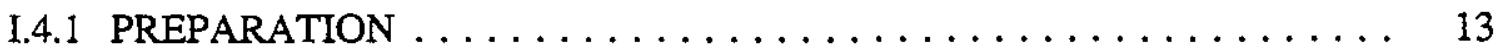

II. THEORETICAL BACKGROUND AND LITERATURE SURVEY $\ldots \ldots \ldots \ldots 14$

II.1 METALLOTHERMIC REDUCTION PROCESS $\ldots \ldots \ldots \ldots \ldots \ldots .14$

II.2 STRONTIUM METAL PRODUCTION BY METALLOTHERMIC

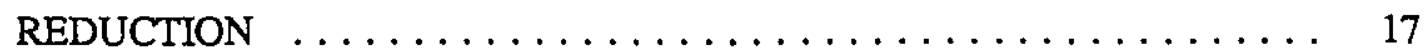

$\Pi$ II.3 STRONTTUM COMPOUNDS $\ldots \ldots \ldots \ldots \ldots \ldots \ldots \ldots \ldots \ldots \ldots \ldots$

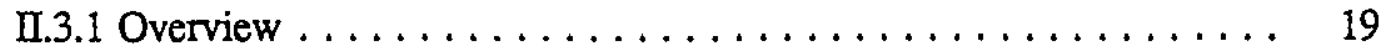

II.3.2 Preparation . . . . . . . . . . . . . . . . . 19

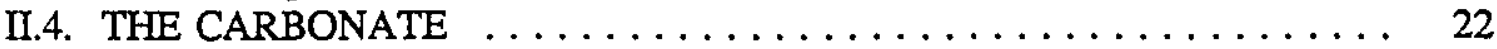

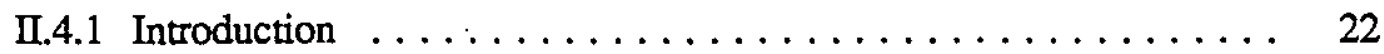

II.4.2 Crystallography ..................... 22

II.4.3 Summary of Carbonate Decomposition ............. 23

II.5 INTERFACIAL PHENOMENA $\ldots \ldots \ldots \ldots \ldots \ldots \ldots \ldots \ldots \ldots \ldots$

II.5.1 Surface Tensions of Metals ................. 25

III. PHYSICAL PROPERTIES OF THE METALS OF CONCERN

TO THIS WORK (Al, $\mathrm{Mg}, \mathrm{Sr}$ and $\mathrm{Bi}) \ldots \ldots \ldots \ldots \ldots \ldots \ldots \ldots \ldots \ldots$

III.1 PHYSICAL PROPERTIES OF LIQUID ALUMINUM $\ldots \ldots \ldots \ldots \ldots, 31$

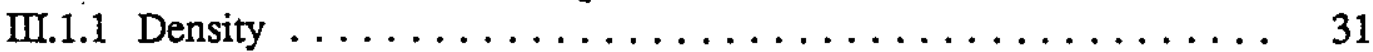

III.1.2 Surface Tension ..................... 32

III.1.3 Vapour Pressure $\ldots \ldots \ldots \ldots \ldots \ldots \ldots \ldots \ldots \ldots \ldots . \ldots \ldots$

III.2 PHYSICAL PROPERTIES OF LIQUID STRONTIUM $\ldots \ldots \ldots \ldots \ldots .35$

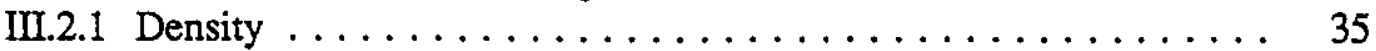

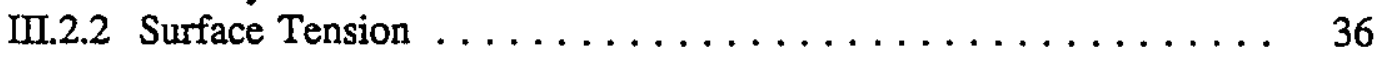

III.2.3 Vapour Pressure $\ldots \ldots \ldots \ldots \ldots \ldots \ldots \ldots \ldots \ldots \ldots . \quad 36$

III.3 PHYSICAL PROPERTIES OF LIQUID MAGNESIUM $\ldots \ldots \ldots \ldots .38$ 
III.3.1 Density $\ldots \ldots \ldots \ldots \ldots \ldots \ldots \ldots \ldots \ldots \ldots \ldots \ldots, 38$

III.3.2 Surface Tension ....................... 38

III.3.3 Vapour Pressure ...................... 39

III.4 PHYSICAL PROPERTIES OF LIQUID BISMUTH $\ldots \ldots \ldots \ldots \ldots \ldots, 41$

III.4.1 Density . ........................ 41

III.4.2 Surface Tension ....................... 41

III.4.3 Vapour Pressure $\ldots \ldots \ldots \ldots \ldots \ldots \ldots \ldots \ldots \ldots \ldots, 42$

IV. THERMODYNAMIC SIMULATION OF $\mathrm{SrCO}_{3}$ REDUCTION $\ldots \ldots \ldots \ldots$

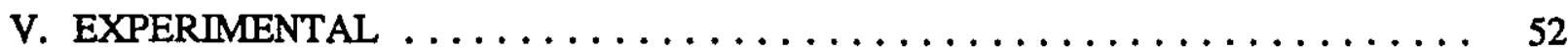

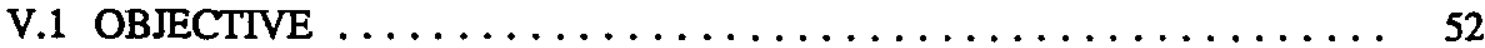

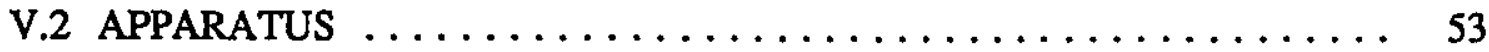

V.2.1 Induction Furnace $\ldots \ldots \ldots \ldots \ldots \ldots \ldots \ldots \ldots \ldots, 53$

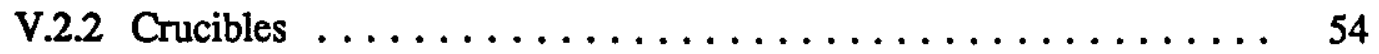

V.2.3 Impeller ......................... 55

V.2.4 Impeller Drive and Support Carriage $\ldots \ldots \ldots \ldots \ldots \ldots \ldots 56$

V.2.5 Thermocouples ...................... 57

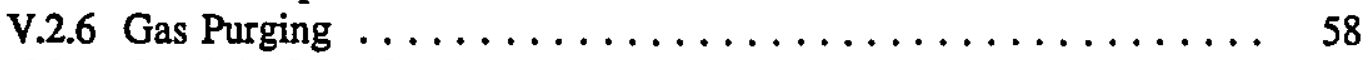

V.2.7 Crucible Cap (Condenser) $\ldots \ldots \ldots \ldots \ldots \ldots \ldots \ldots \ldots$

V.2.8 Sampling Method $\ldots \ldots \ldots \ldots \ldots \ldots \ldots \ldots \ldots \ldots, 60$

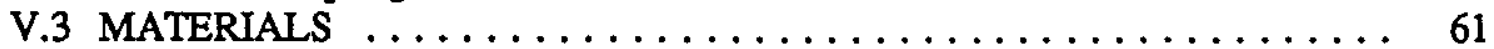

V.4 EXPERIMENTAL PREPARATION $\ldots \ldots \ldots \ldots \ldots \ldots \ldots \ldots \ldots, 62$

V.4.1 Experimental Parameters .................... 62

V.5 EXP. RIMENTAL PROCEDURES FOR REDUCTION EXPERIMENTS .. 63

V.5.1 Preparation of Experiments . . . . . . . . . . . . . . 63

V.5.2 Experimental Procedures $\ldots \ldots \ldots \ldots \ldots \ldots \ldots \ldots, 65$

V.6 EXPERIMENTAL PROGRAM $\ldots \ldots \ldots \ldots \ldots \ldots \ldots \ldots \ldots \ldots 6$

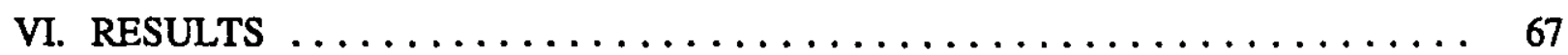

VI.1 REACTION PRODUCTS $\ldots \ldots \ldots \ldots \ldots \ldots \ldots \ldots \ldots \ldots \ldots \ldots$

VI.2 XRD ANALYSIS OF POWDER RESIDUE $\ldots \ldots \ldots \ldots \ldots \ldots \ldots, 76$

VI.3 ATOMIC ABSORPTION ASSAYS $\ldots \ldots \ldots \ldots \ldots \ldots \ldots \ldots .78$

VI.3.1 Sample Preparation ..................... 79

V1.3.2 Atomic Absorption Results ................. 79

VI.4 OPTICAL MICROSCOPE EXAMINATIONS $\ldots \ldots \ldots \ldots \ldots \ldots \ldots 83$

VI.5 SCANNING ELECTRON MICROSCOPE ANALYSIS . . . . . . . 86

VII. Calculations ............................... 90

VII.1 EXAMPLE CALCULATIONS OF CHEMICAL ASSAYS . . . . . . . 90

VII.2 SAMPLING AND ANALYTICAL ERRORS ............. 93

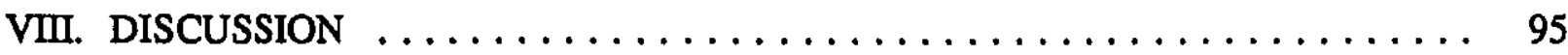

VIII.1 INTRODUCTION $\ldots \ldots \ldots \ldots \ldots \ldots \ldots \ldots \ldots \ldots \ldots, 95$ 
VIII.1.2 DISCUSSION OF THE EXPERIMENTAL PROGRAM AS PERFORMED $\ldots \ldots \ldots \ldots \ldots \ldots, 96$

VIII.1.3 DISCUSSION OF THE EXPERIMENTAL PROCEDURE ....................... 96

VIII.2 COMPARISON OF INGOT ASSAYS $\ldots \ldots \ldots \ldots \ldots \ldots \ldots \ldots, 97$

VIII.3 MASS BALANCES $\ldots \ldots \ldots \ldots \ldots \ldots \ldots \ldots \ldots \ldots \ldots$

VIII.4 THE EFFECT OF METAL SOLUTE ADDITIONS ON

THE DROSS AND POWDER PRODUCT ASSAYS . ........ 102

VIII.4.1 Effect of Magnesium Addition............... 102

VIII.5 STRONTIUM RECOVERY FROM $\mathrm{SrCO}_{3}$ VS. $\mathrm{Mg}$ and Bi ADDITION ........................ 106

VIII.5.1 Distribution to Reaction Products ......................... 110

VIII.6 DISCUSSION OF XRD RESULTS $\ldots \ldots \ldots \ldots \ldots \ldots \ldots \ldots \ldots, 114$

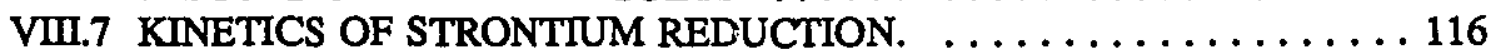

VIII.8 VACUUM DISTILLATION OF STRONTIUM FROM ALUMINUM ALlOYS . ...................... 119

VIII.9 DISCUSSION OF THE THERMODYNAMIC SIMULATION OF THE EXPERIMENTS $\ldots \ldots \ldots \ldots \ldots \ldots \ldots, 122$

IX. THERMODYNAMIC EVALUATION OF THE MLE PROCESS INVOLVING ALUMINOTHERMIC REDUCTION OF $\mathrm{SrCO}_{3} \ldots \ldots \ldots \ldots \ldots \ldots \ldots \ldots, 125$

X. CONCLUSIONS AND SUGGESTIONS FOR FUTURE WORKS $\ldots \ldots \ldots \ldots, 131$

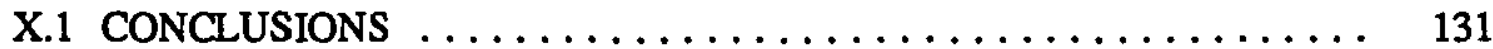

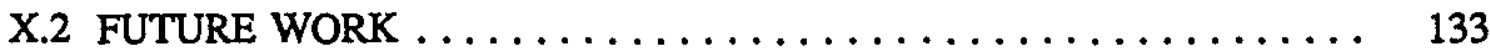

X.3 CONTRIBUTION TO KNOWLEDGE $\ldots \ldots \ldots \ldots \ldots \ldots \ldots \ldots .135$

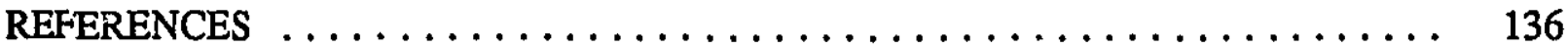

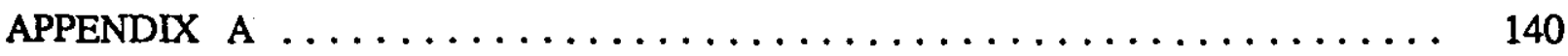

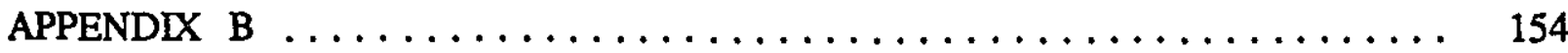




\section{LIST OF TABLES}

Page No.

Table I

The Alkali Elements

Table II

The Alkaline-Earth Elements

Table III

The Physical Properties of Strontium

4

Table IV

World Celestite Production (by Country)

Table V

U.S. Distribution of Primary Strontium Compounds

Table VI

Typical Metal Reductants

Table VII

Typical Surface Tension for Metals, $\gamma_{L o}$

Table VIII

Selected Surface Tension Values

28

Table IX

Surface Tension Values for each Experiment

29

Table X

Classification of Pure Aluminum

Table XI

Density of Liquid Aluminum versus Temperature

32

Table XII

Surface Tension of Liquid Aluminum versus Temperature

33

Table XIII

Vapour Pressure of Liquid Aluminum

Table XIV

Density of Liquid Strontium vs. Temperature

Table XV

Surface Tension of Liquid Strontium vs. Temperature

Table XVI

Vapour Pressure of Liquid Strontium

Table XVII

Density of Liquid Magnesium versus Temperature

Table XVIII

Surface Tension of Magnesium versus Temperature

Table XIX

Vapour Pressure of Liquid Magnesium

Table XX

Density of Liquid Bismuth versus Temperature 
Table XXI

Table XXII

Table XXII

Table XXIII

Table XXIV

Table XXV

Table XXVI

Tabie XXVII

Table XXVIII

Table XXIX

Table XXX

Table XXXI

Table XXXII

Table XXXIII

Table XXXIV

Table XXXV

Table XXXVI

Table XXXVII

Table XXXVIII

Table XXXIX
Surface Tension of Liquid Bismuth versus Temperature

Vapour Pressure of Liquid Bismuth

Strontium and Metal Reductant Properties

46

Thermodynamic data for the Dissolution of Metallic

Species in Aluminum

48

$F^{*} A * C * T$ Prediction of Reaction Products Al-Mg

Alloy at $1273 \mathrm{~K}$ and $1 \mathrm{~atm}$.

$\mathrm{F}^{*} \mathrm{~A} \mathrm{C}^{*} \mathrm{~T}$ Prediction of Reaction Products Al-Ca

Alloy at $1273 \mathrm{~K}$ and $1 \mathrm{~atm}$.

$F^{*} A * C * T$ Prediction of Reaction Products Al-Na

Alloy at $1273 \mathrm{~K}$ and $1 \mathrm{~atm}$.

$\mathrm{F}^{*} \mathrm{~A} \mathrm{C}^{*} \mathrm{~T}$ Prediction of Reaction Products Al-Na

Alloy at $1273 \mathrm{~K}$ and 1 atm.

Experimental Program

Mass Balance for the Reaction Products

69

XRD Results for Powder Residue

77

Data of Standards and Ingots Assays

80

Assays of Ingot

80

Assays of Dross $\quad 81$

Assays of Powder

81

Strontium Assays from Kinetics $\quad 82$

SEM Assay of Intermetallic (Weight \%)

86

Example of Linear Regression Results from QUATTRO PRO

90

Comparison of assay results

97

Mass Balance for Strontium 
Table XL

1

Table XII
Mass Balance for Magnesium

99

Table XLII
Mass Balance for Bismuth

100

Volatility Coefficient for Various Solute Metals, $\Phi_{i}$ 


\section{LIST OF FIGURES}

Page No.

Figure 1 Celestite crystals $\quad 6$

$\begin{array}{llc}\text { Figure } 2 & \text { Strontianite crystals } & 6\end{array}$

Figure $3 \quad$ Schematic representation of horizontal retort (Pidgeon process) 15

$\begin{array}{lll}\text { Figure } 4 & \text { Schematic representation of solid-solid processing } & 16\end{array}$

Figure 5 Schematic representation of the possible current strontium $\begin{array}{ll}\text { production method } & 18\end{array}$

Figure 6 Schematic representation of the carbonate ion structure 22

$\begin{array}{lll}\text { Figure } 7 & \text { Contact Angle } & 26\end{array}$

Figure 8 Surface tensions for aluminum with solute metals at 50 to $80^{\circ} \mathrm{C}$ above the liquidus 28

Figure 9 Schematic of the Possible Reaction Mechanism with Magnesium present in the Aluminum Reductant

$\begin{array}{lll}\text { Figure } 10 & \text { Ellingham Diagram } & 45\end{array}$

Figure 11 Strontium Extraction with $\mathrm{Mg}, \mathrm{Ca}$ and $\mathrm{Na}$ Additions 47

Figure 12 Tocco Induction Furnace and Generator 53

Figure 13 Bonded Alumina Crucible with Thermocouples in place 54

Figure 14 Schematic of the Impeller and the Skeleton 55

$\begin{array}{lll}\text { Figure } 15 & \text { Alumina Inpeller } & 55\end{array}$

Figure 16 Schematic Representation of the Apparatus 56

$\begin{array}{lll}\text { Figure } 17 & \text { Temperature Variance with Time } & 57\end{array}$

$\begin{array}{lll}\text { Figure } 18 & \text { Condenser Cap for the Crucible } & 59\end{array}$ 
Figure 19 Schematic of the sampling method

Figure $20 \quad$ Drying and firing program of alumina cement 64

Figure 21 Size Fraction of the Powder Residue for Experiments 0 to 5

Figure 22 Size Fraction of the Powder Residue for Experiments 6 to $8 \quad 68$

$\begin{array}{lll}\text { Figure } 23 & \text { Condensate (Experiments } 1 \text { to } 5) & 70\end{array}$

Figure $24 \quad$ White plume escaping by the shaft hole 71

$\begin{array}{lll}\text { Figure } 25 & \text { Powder residue } & 71\end{array}$

$\begin{array}{lll}\text { Figure } 26 & \text { Dross } & 72\end{array}$

$\begin{array}{lll}\text { Figure } 27 & \text { Dross on top of the melt and powder on the crucible wall } & 73\end{array}$

$\begin{array}{lll}\text { Figure } 28 & \text { Mass of reaction products for each experiment } & 74\end{array}$

Figure $29 \quad$ Metal ingot (Mg addition)

$\begin{array}{lll}\text { Figure } 30 \quad \text { Metal ingot (Bismuth addition) } & 75\end{array}$

Figure 31 Microstructure of the ingot for Experiment 0 (0Mg:Sr) 83

Figure 32 Microstructure of the ingot for Experiment 3 (6Mg:Sr) 84

Figure 33 Microstructure of the ingot for Experiment 5 (10Mg:Sr) 84

Figure 34 Microstructure of the ingot for Experiment $8(6 \mathrm{Wt} \% \mathrm{Bi}) \quad 85$

$\begin{array}{lll}\text { Figure } 35 & \text { Dross Surface }(1500 \mathrm{X}) & 87\end{array}$

Figure $36 \quad$ Condensate for Experiments 1 to 5 (350 X) 88

Figure 37 Condensate for Experiments 6 to $8(350 \mathrm{X}) \quad 89$

$\begin{array}{lll}\text { Figure } 38 & \text { Calibration Curve } & 91\end{array}$

Figure $39 \quad$ Strontium Concentration in Dross and Powder (Mg Addition) 103

Figure $40 \quad$ Strontium Concentration in Dross and Powder (Bi Addition) 104 
Figure 41 Magnesium Concentration in Reaction Products

Figure 42 Bismuth Concentration in Reaction Products

Figure 43 Strontium Recovery vs. Mg:Sr Molar Ratio

Figure 44 Strontium Recovery with Bismuth Addition

Figure 45 Strontium Distribution to Reaction Products

Figure 46 Magnesium Distribution to Reaction Products

Figure 47 Bismuth Distribution to Reaction Products

Figure 48 Schematic Representation Stagnant Zone of $\mathrm{SrCO}_{3}$

Figure 49 Strontium Recovery to the Melt as a function of Time and $\mathrm{Mg}$ Additions

Figure 50 Stontium Recovery to the Melt as a function of Time and Bismuth Additions

Figure 51 Experimental and Predicted Sr Recovery from $\mathrm{SrCO}_{3}$ (Magnesium Addition)

Figure 52 Experimental and Predicted Sr Recovery (Bismuth Addition)

Figure $53 \mathrm{Sr}$ Extraction from $\mathrm{SrCO}_{3}$ vs. Temperature

Figure 54 Sr Extraction from $\mathrm{SrCO}_{3}$ vs. Log P

Figure 55 Pressure and Temperature Dependence at 100\% Sr Extraction

Figure 56 Sr Extraction vs. Al:Sr Molar Ratio

Figure 57 Sr Extraction from $\mathrm{SrCO}_{3}$ vs. $\mathrm{Mg}: \mathrm{Sr}$ Molar Ratio and Temperature Variation

Figure B.1 Phase diagram of Al-Mg-Sr alloys at $673 \mathrm{~K}$

Figure B.2 Al-Mg Binary Phase Diagram

Figure B.3 Al-Sr Binary Phase Diagram 
$\begin{array}{lll}\text { Figure B.4 Mg-Sr Binary Phase Diagram } & 157\end{array}$

1 Figure B.5 Al-Bi Binary Phase Diagram 158

$\begin{array}{lll}\text { Figure B.6 Bi-Sr Binary Phase Diagram } & 159\end{array}$ 


\section{INTRODUCTION}

\section{I.1 MELT-LEACH-EVAPORATION PROCESS}

The Melt-Leach-Evaporation (MLE) ${ }^{(1)}$ process is under developement for the extraction of valuable Group IA or IIA metals of the Periodic Table, such as lithium, calcium, magnesium and strontium. The process consists of mixing and contacting the value metal source material, which might be an ore or concentrate, with an excess of molten metal which is acting as a reductant and lixiviant. In the process, the value metal extracted from the source material is dissolved in the excess molten metallic solvent and is subsequently extracted as a vapour by vacuum distillation (Ref. 2 to 7). The vapour is condensed and recuperated in the metallic state.

The MLE process presents many advantages over existing pyrometallurgical methods which use metallic reductants for the production of some alkaline-earth metals, such as beryllium, magnesium, calcium, strontium and barium. For example, MLE improves materials handling and production rates as compared to solid state powder processes such as the Pidgeon process which uses vacuum retorts because in MLE, an excess of molten reductant is employed in order to form a more easily handled molten alloy mixture of the reductant and the extracted metallic species.

The subject of this thesis is the extraction of strontium from strontium carbonate $\left(\mathrm{SrCO}_{3}\right)$ by metallothermic reduction using an excess of aluminum as the molten metallic reductant. This subject is representative of the extraction step of the MLE process. The vacuum distillation of strontium from the molten alloy was not examined experimentally in this thesis. 


\section{I.2.1 THE METAL STRONTIUM}

Until recently, strontium was one of the less important elements from the productionvolume point of view. This situation has been changed, however, by the discovery of various commercial uses for strontium. Strontium has found increased application in the automobile and aerospace industries since the 1970's resulting in growing demand for the metal. Strontium is a reactive metal making it difficult and costly to produce except under carefully controlled processes. Strontium is a silvery white metal that occurs naturally as celestite $\left(\mathrm{SrSO}_{4}\right)$ and strontianite $\left(\mathrm{SrCO}_{3}\right)$. Stontianite was first discovered in 1790 by Adair Crawford ${ }^{(8)}$, and was long thought to be a barium mineral. This discovery was confirmed two years later by T.C. Hope ${ }^{(9)}$. The mineral was named strontianite because it was found near Strontian, a small town in Argyllshire, Scotland. In 1808 , Sir Humphrey Davy ${ }^{(9)}$ produced strontium metal but only in the form of a mercury amalgam. Only some fifty years later, was R. Bunsen ${ }^{(9)}$ was able to produce a small quantity of strontium metal by electrolysis of fused chloride. The alkali and alkaline-earth metals are presented in Tables I and II.

Table I The Alkali Elements

\begin{tabular}{|l|c|c|c|}
\hline ELEMENTS & SYMBOL & ATOMIC No. & ATOMIC WEIGHT \\
\hline Lithium & $\mathrm{Li}$ & 3 & 6.941 \\
Sodium & $\mathrm{Na}$ & 11 & 22.989 \\
Potassium & $\mathrm{K}$ & 19 & 39.098 \\
Rubidium & $\mathrm{Rb}$ & 37 & 85.468 \\
\hline
\end{tabular}


Table II The Alkaline-Earth Elements

\begin{tabular}{|l|c|c|c|}
\hline ELEMENTS & SYMBOL & ATOMIC No. & ATOMIC WEIGHT \\
\hline Beryllium & $\mathrm{Be}$ & 4 & 9.012 \\
Magnesium & $\mathrm{Mg}$ & 12 & 24.305 \\
Calcium & $\mathrm{Ca}$ & 20 & 40.080 \\
Strontium & $\mathrm{Sr}$ & 38 & 87.620 \\
Barium & $\mathrm{Ba}$ & 56 & 137.330 \\
\hline
\end{tabular}




\section{I.2.2 THE ELEMENT STRONTIUM}

Strontium is a divalent element of the group IIA of the Periodic Table (a group that also includes beryllium, magnesium, calcium, barium and radium). The elements of this group are termed alkaline-earth metals because their oxides have chemical properties intermediate between the hydroxides of alkali-metals, i.e., sodium and potassium, and the oxides of earth metals, i.e., magnesium, aluminum and iron. The strontium physical properties are summarized in Table III.

Table III The Physical Properties of Strontium ${ }^{(10)}$

\begin{tabular}{|c|c|c|}
\hline PROPERTIPS & VALUES & Ref. \\
\hline ATOMIC WEIGHT & 87.62 & 9 \\
\hline OXIDATION STATE & 2 & 9 \\
\hline ELECTRON CONFIGURATION & {$[\mathrm{Kr}] 5 \mathrm{~s}^{2}$} & 9 \\
\hline MELTING POINT $\left({ }^{\circ} \mathrm{C}\right)$ & 768 & 9 \\
\hline BOLING POINT $\left({ }^{\circ} \mathrm{C}\right)$ & 1377 & 9 \\
\hline DENSITY $\left(\mathrm{g} / \mathrm{cm}^{3}\right)$ & 2.6 & 9 \\
\hline COVALENT RADIUS ( $(\AA)$ & 1.91 & 9 \\
\hline ATOMIC RADIUS $(\AA)$ & 2.45 & 9 \\
\hline FIRST IONIZATION POTENTIAL (eV) & 5.695 & 9 \\
\hline ATOMIC VOLUME $\left(\mathrm{cm}^{3} / \mathrm{mol}\right)$ & 33.7 & 9 \\
\hline SPECIFIC HEAT CAPACITY $(\mathrm{J} / \mathrm{g} \cdot \mathrm{K})$ & 0.30 & 9 \\
\hline HEAT OF FUSION $(\mathrm{kJ} / \mathrm{mol})$ & 8.30 & 9 \\
\hline HEAT OF VAPORIZATION $(\mathrm{kJ} / \mathrm{mol})$ & 144.0 & 9 \\
\hline CRYSTAL STRUCTURE & $\mathrm{CFC}$ & 9 \\
\hline
\end{tabular}

Strontium represents $0.02-0.03 \%$ of the earth's crust and is the fifth most abundant metallic ion in seawate ${ }^{(11,12)}$ after $\mathrm{Na}, \mathrm{Mg}, \mathrm{Ca}$, and $\mathrm{K}$. The pure metal is silvery white and is slightly alkaline. The alkaline-earth elements are strongly electropositive. The common 
bivalence is explained by the presence of two electrons in the outer ( $\mathrm{s}$ ) shell of each neutral atom.

\section{I.2.3 STRONTIUM OCCURRENCE}

Celestite (strontium sulfate, $\mathrm{SrSO}_{4}$ ) is the main ore of strontium, Figure 1. The celestite crystals are commonly tabular and closely resemble those of barite. The only other natural source of strontium is strontianite (strontium carbonate, $\mathrm{SrCO}_{3}$ ), Figure 2. Radiating fibrous and granular forms of the mineral are encountered for both celestite and strontianite.

The natural carbonate, less abundant and not so widespread in its occurrence, is uneconomical to mine. Furthermore, $\mathrm{SrCO}_{3}$ generally occurs with calcite and lead sulfide, and for most uses, these impurities are detrimental.

Both terms, celestite and celestine, are employed to describe the strontium sulphate mineral. Celestine is derived from the original German world "coelestin" ("coelestine" in English texts) which was introduced by Werner in 1798. In the Chemical Index of Minerals, $2^{\text {nd }}$ Edition 1955 , celestine was stated to be the preferred spelling. However, the term celestite is the form currently most widely accepted in English-speaking countries. Celestite has a theoretical strontium oxide content of 56.4 percent. It has a hardness of 3-3.5 according to the Mohs'scale and a high specific gravity of approximately 3.96 . The mineral is usually white but other colour such as blue and less commonly red, green and brown have also been observed. The crystallographic form of celestite and strontianite is orthorhombic often showing a tabular habit. Strontianite has a theoretical strontium oxidi content of 70.1 percent. It has a hardness of 3.5-4 (Mohs'scale) and a specific gravity of 3.7 . 


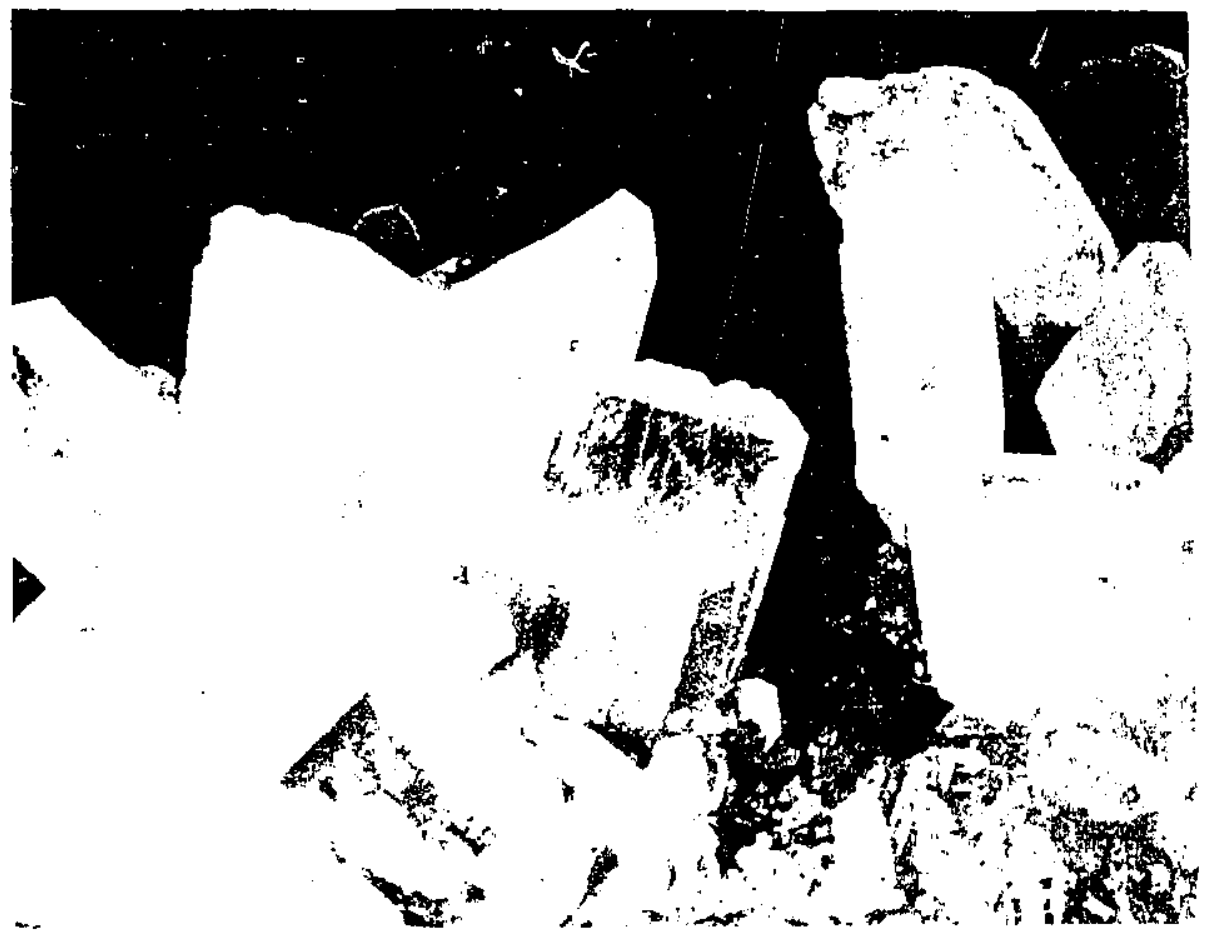

Figure 1 Celestite crystals

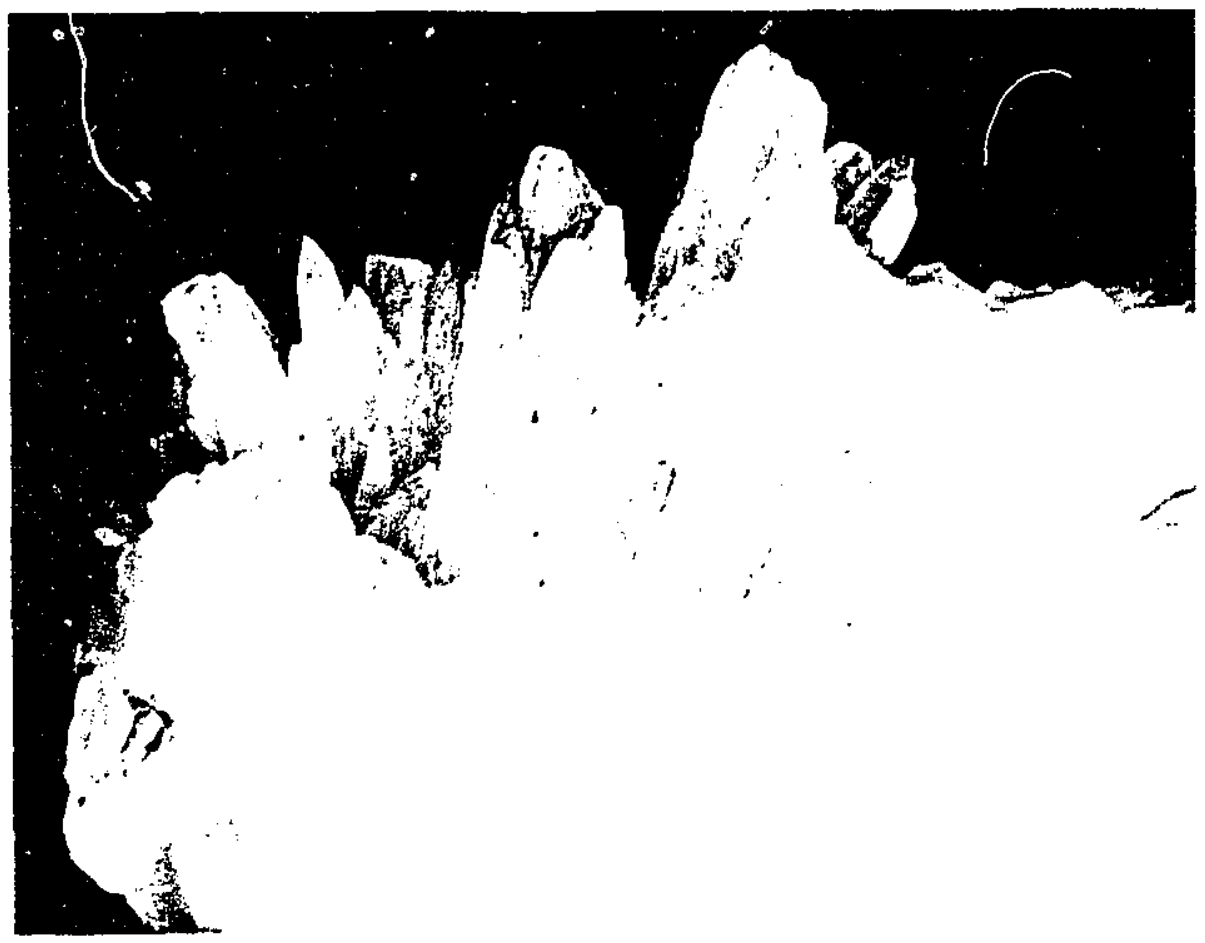

Figure 2 Strontianite crystals 


\section{I.2.4 CONSUMPTION}

Although strontium minerals have not been mined in U.S since $1959^{(13)}$, the United States is a major producer and consumer of strontium compounds. Production of celestite is principally in Mexico, Turkey, Spain and Iran followed by the United Kingdom and Cyprus. In $1988^{(13)}$, celestite was mined in twelve countries from large, high grade, sedimentary deposits. The sulfate mineral is converted into strontium carbonate, the most popular strontium compound. Most other compounds containing strontium are derived from it. Other countries of production as well as the main producers are listed in Table IV. Mexico and Spain represent nearly two-thirds of the word celestite production. The U.S imports of strontium minerals were about 42,000 short tons in 1987-88. Imports of strontium compounds increased by about $45 \%$ between 1987 and $1988^{(13)}$. Imports of strontium carbonate from Mexico increased by nearly $300 \%$ in 1988 . This year was the first full year of production at a new carbonate facility in Torreon, Coahuila State, Mexico.

Table IV World Celestite Production (by Country)

\begin{tabular}{|l|r|r|r|r|r|r||}
\hline \multicolumn{1}{|c|}{ Country } & \multicolumn{1}{c|}{1976} & \multicolumn{1}{c|}{1983} & \multicolumn{1}{c|}{1984} & 1985 & \multicolumn{1}{c|}{1986} & \multicolumn{1}{c|}{1987} \\
\hline Algeria & 7147 & 6000 & 6000 & 6000 & 6000 & 6000 \\
Argentina & 2264 & 742 & 441 & 1084 & 1249 & 1100 \\
Canada & 13200 & - & - & - & - & - \\
Cyprus & - & - & - & 1543 & 8119 & 8000 \\
Iran & 6000 & 24251 & 23149 & 27558 & 24251 & 24250 \\
Italy & 700 & 456 & 2866 & 5083 & 5144 & 195 \\
Mexico & 24424 & 41343 & 35264 & 33601 & 26774 & 68597 \\
Pakistan & 665 & 149 & 622 & 791 & 1099 & 1100 \\
Spain & 9100 & 38000 & 29760 & 46848 & 38030 & 38000 \\
Turkey & 7000 & 42808 & 38600 & 38600 & 38600 & 38600 \\
UK & 5952 & 13340 & 17750 & 25353 & 15543 & 16500 \\
\hline \multicolumn{1}{|c|}{ TOTAL } & 76522 & 167089 & 154452 & 186461 & 164809 & 202642 \\
\hline
\end{tabular}


Mexico: Mexico supplied 99\% of the U.S celestite imports from 1976 through 1980 . The main producer is Minera Valenciana. The headquarters is located in Torreon with mines in the Paila district. The celestite is found as lens-shaped bodies concordant with bedding of the gently dipping Cretaceous limestone host rock. The thickness of the lenses varies with an average of two meters. The ore is mined underground. Chemical Products Corp. (CPC) ${ }^{(14)}$ of Cartersville, GA, is the bigger U.S. producer of strontium compounds from the celestite ore. About 2000 stpy $^{(15)}$ are consumed by low lead electrolytic zinc manufactirers in Canada and US.

Spain: The producer of celestite in Spain is the company, Bruno SA, Madrid, which exploits the Aurora Mine in Montevive. The mine is open pit. The celestite is mined from the baritic gypsiferous host rocks. Recent expansion at the Aurora Mine has increased its capacity to 40,000 stpy, with a typical $\mathrm{SrSO}_{4}$ assay of 93 to $94 \%$. Deposits reported by the Spanish Government near Fortuna in Murcia, called Nuestra Senora, indicate possibilities of extracting celestite ore with $98 \% \mathrm{SrSO}_{4}$ grade.

Turkey: Barit Moden Turk is the largest producer of celestite in Turkey. Its Silvas operation is expanding production from the current 20,000 stpy to 40,000 stpy capacity.

Canada: The Kaiser Chemical Co. attempted to develop an open pit mine at Lock Lommond, Cape Breton County, Nova Scotia. The ore averaging 50 to $60 \% \mathrm{SrSO}_{4}$ was upgraded to $88 \%$ $\mathrm{SrSO}_{4}$ by froth flotation. The mineralization occurs in rocks of the lower Windsor group of mississippian age as gently dipping mantos concordant to bedding of the host rocks of limestone 
and gypsum. The open pit mine operations started in September 1969 and were followed in March 1971 by the first production of celestite concentrates. The production continued until its closure in August 1976 because of celestite ore quality and process probiems.

United States: All known deposits of United States are uneconomic in today's markets. Historically production has been sporadic and brief. The U.S manufacturers of strontium compounds depend on imports of celestite. Furthermore, strong competition from Italy and West Germany is present in the U.S market for finished strontium compounds.

The present world needs are satisfied by mining of celestite from well-established sources abroad. Moreover, other deposits are known and could be exploited in order to meet new or expanded requirements. 


\section{I.3 CHARACTERISTICS AND USES OF STRONTIUM}

Strontium is principally used in the form of compounds. The strontium compounds are used mainly in pyrotechnic, electronic, glass, ceramic and paint industries. Other important uses of strontium compounds and strontium metal are found in the metallurgical industry. Table $\mathrm{V}$, shows the U.S. estimated distribution of uses of primary strontium compounds ${ }^{(16)}$.

Table Y U.S. Distribution of Primary Strontium Compounds

\begin{tabular}{|c|c|c|c|}
\hline End Use (in Percent) & 1985 & 1986 & 1987 \\
\hline $\begin{array}{l}\text { Electrolytic Production of Zinc } \\
\text { Ferrite Ceramic Magnets } \\
\text { Pigments and Fillers } \\
\text { Pyrotechnics and Signals } \\
\text { Television Picture Tubes } \\
\text { Other }\end{array}$ & $\begin{array}{c}6 \\
12 \\
8 \\
15 \\
52 \\
7\end{array}$ & $\begin{array}{c}6 \\
11 \\
7 \\
12 \\
60 \\
4\end{array}$ & $\begin{array}{c}5 \\
11 \\
5 \\
13 \\
63 \\
3\end{array}$ \\
\hline TOTAL & 100 & 100 & 100 \\
\hline
\end{tabular}

\subsubsection{Pyrotechnics}

The celestite is first transformed to carbonate, the chemical from which most other strontium compounds are derived. Most of the chemical compounds derived from strontium have a brilliant crimson flame when burning. This peculiarity makes them useful in making marine distress flares, fireworks, tracer ammunition and signal flares ${ }^{(13)(17)}$. Strontium compounds usually comprise less than 10 mass\% of fireworks but this proportion may be much higher in other pyrotechnics. 


\subsubsection{Electrical applications}

Strontium chloride compound is used to produce the phosphors in the activated coatings for fluorescent lighting and colour television screens. Permanent ceramic magnets using strontium hexaferrite $\left(\mathrm{SrO}_{6} \mathrm{Fe}_{2} \mathrm{O}_{3}\right)$ are used in DC motors and telecummunications. Other applications are in radio, television sets, oscillators, lifting equipment, magnetic separators. The ceramic magnets are use to replace conventional metallic magnets where saving in size and weight and higher efficiency are required. Strontium titanate, stannate and zirconate are found applications such as ceramic dielectric material for electrical capacitors.

\section{I.3.3 Glass and Ceramics Industries}

Strontium compounds incorporated in glass reduce the emission of secondary X-ray during operation of colour television tubes. Several other types of glass such as; iridescent, optical and leadless crystal glasses use also strontium compounds. In glazes, replacement of $\mathrm{Ca}$ or $\mathrm{Ba}$ compounds by Sr compounds increases the complexity of the system and decreases the fusion point.

\section{I.3.4 Paints and Rubber Industries}

In paints, celestite is used as a brightening and whitening agent. Strontium sulfide has been utilized for many years as the phosphorescent pigment in luminous paints. Strontium 
chromate has been used as anti-corrosive primer, particularly applied to zinc, magnesium and aluminum, and in alloys used for aircraft where high heat, water and alkali resistance are needed. Solvent based water soluble resins bearing strontium chromate are used in stoving primers and surfacers for road vehicles and aircraft. The main advantages of using the strontium salt are nontoxicity, non-flammability, non-gelation of acid media and also that water can be used as a diluent. In the rubber industry, strontium compounds may be used as filler. A filler is used to reinforce or modify physical properties, impart certain processing properties or simply reduce the cost.

\section{I.3.5 Metallurgical Industries}

Strontium metal and alloys have been used as getters to remove traces of gases from electronic tubes and as a scavenger in metallurgy to purify other metals. It has been also used in very small quantities to improve the hardness and durability of lead and copper. The use of strontium-silicon as inoculant has been developed in the production of high quality iron casting.

Strontium metal is also used as a modifier. Strontium modifies the eutectic silicon in hypo and hyper eutectic aluminum/silicon casting alloys from coarse platelet to fine fiber form. This gives over $80 \%$ improvement in as-cast ductility, which permits selection of a tempering treatment to greatly improve tensile strength while retaining adequate ductility. It also enhances feeding in the mold. Strontium carbonate permits the production of high purity (low lead) electrolytic zinc by a process patented by the American Smelting and Refining Company. The process requires 2.8 to $3.3 \mathrm{~kg} \mathrm{SrCO}$ per ton of zinc produced. 


\section{I.4. STRONTIUM METAL}

\section{I.4.1 PREPARATION}

Metallic strontium was first produced by fused sali electrolysis of strontium chloride. Many attempts were made in order to develop this process. The deposited metal had the tendency to migrate into the fused electrolyte rending the method unsatisfactory ${ }^{(18 \times 19)}$ although processes similar to this for the electrolytic production of calcium have been used. The most effective method for strontium production is the metallothermic reduction of its oxide. Strontium oxide is reduced thermally with aluminum according to the following reaction:

$$
3 \mathrm{SrO}+2 \mathrm{Al} \rightarrow 3 \mathrm{Sr}+\mathrm{Al}_{2} \mathrm{O}_{3}
$$

The reaction is endothermic and the equilibrium is continually and favorably shifted to the right by using high vacuum. This process is possible because of the high volatility of the alkaline earth metals (high vapour pressure). The gaseous metal is condensed in a colder area of the apparatus.

Small quantities of strontium can be obtained by decomposition of the corresponding azides.

$$
\operatorname{Sr}\left(N_{3}\right)_{2} \rightarrow S r+3 N_{2}
$$

The reaction, Equation 2, is conducted under vacuum. However, the method yields a finely divided black metal powder highly contaminated with nitride (>10\%) and ignites immediately on contact with air. 


\section{THEORETICAL BACKGROUND AND LITERATURE SURVEY}

\section{II.1 METALLOTHERMIC REDUCTION PROCESS}

The metallothermic process is concerned with the preparation of metals and alloys by reduction of their oxides or halides with metals. Generally, these reactions can be expressed by the equation:

$$
A X+B \rightarrow A+B X
$$

where $\mathrm{X}$ is oxygen, chlorine, or fluorine and $\mathrm{A}$ and $\mathrm{B}$ are two metals. The principal characteristic is that the reducing metal is converted to a solid or a liquid product and not to a gas as in other reduction processes, e.g., where carbon or hydrogen produce $\mathrm{CO}, \mathrm{CO}_{2}$ and $\mathrm{H}_{2} \mathrm{O}$. Metallothermic reduction is used when reduction by carbon, hydrogen or by electrolysis from aqueous solution is not possible. The metals mainly used as a reductant are aluminum, calcium, ferrosilicon, magnesium and sodium, Table VI. The Pidgeon process for the production of magnesium is the most widely known. Magnesium is produced by the reduction of magnesia (in dolomite) using ferrosilicon as reductant. The process takes place in a vacuum retort, Figure 3. 


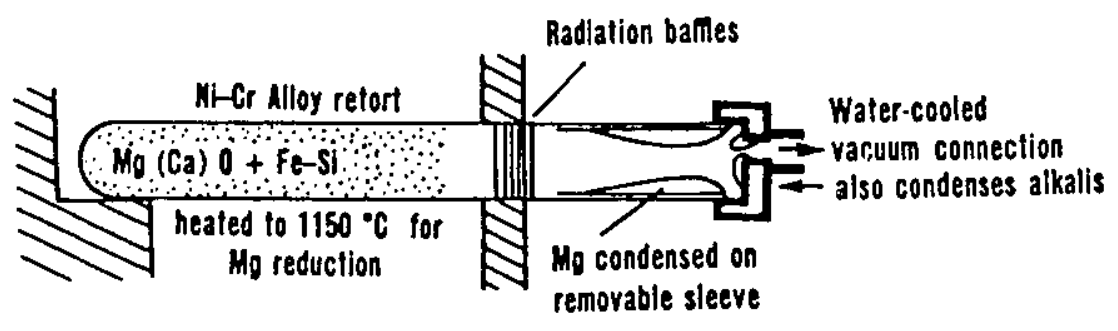

Figure 3 Schematic representation of horizontal retort for the reduction of magnesia in dolomite with ferrosilicon (Pidgeon process)

Table VI Typical Metal Reductants

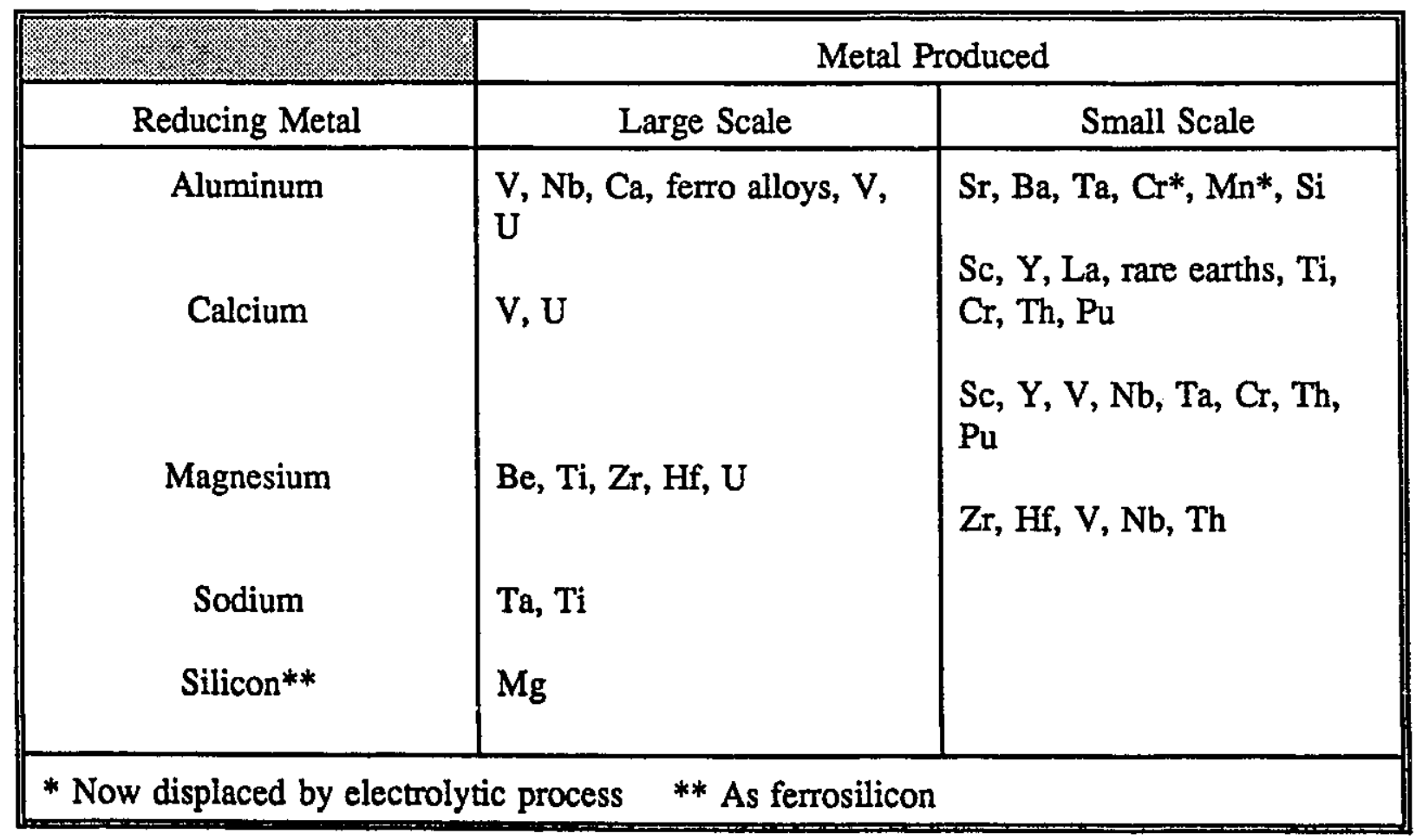


When aluminum is employed as a reducing agent, the process is called "Aluminothermic" reduction and "Calciothermic" when calcium is used. In general the process is a batch process involving solid reactants. The general steps involved in solid-solid reactions are presented in Figure 4.

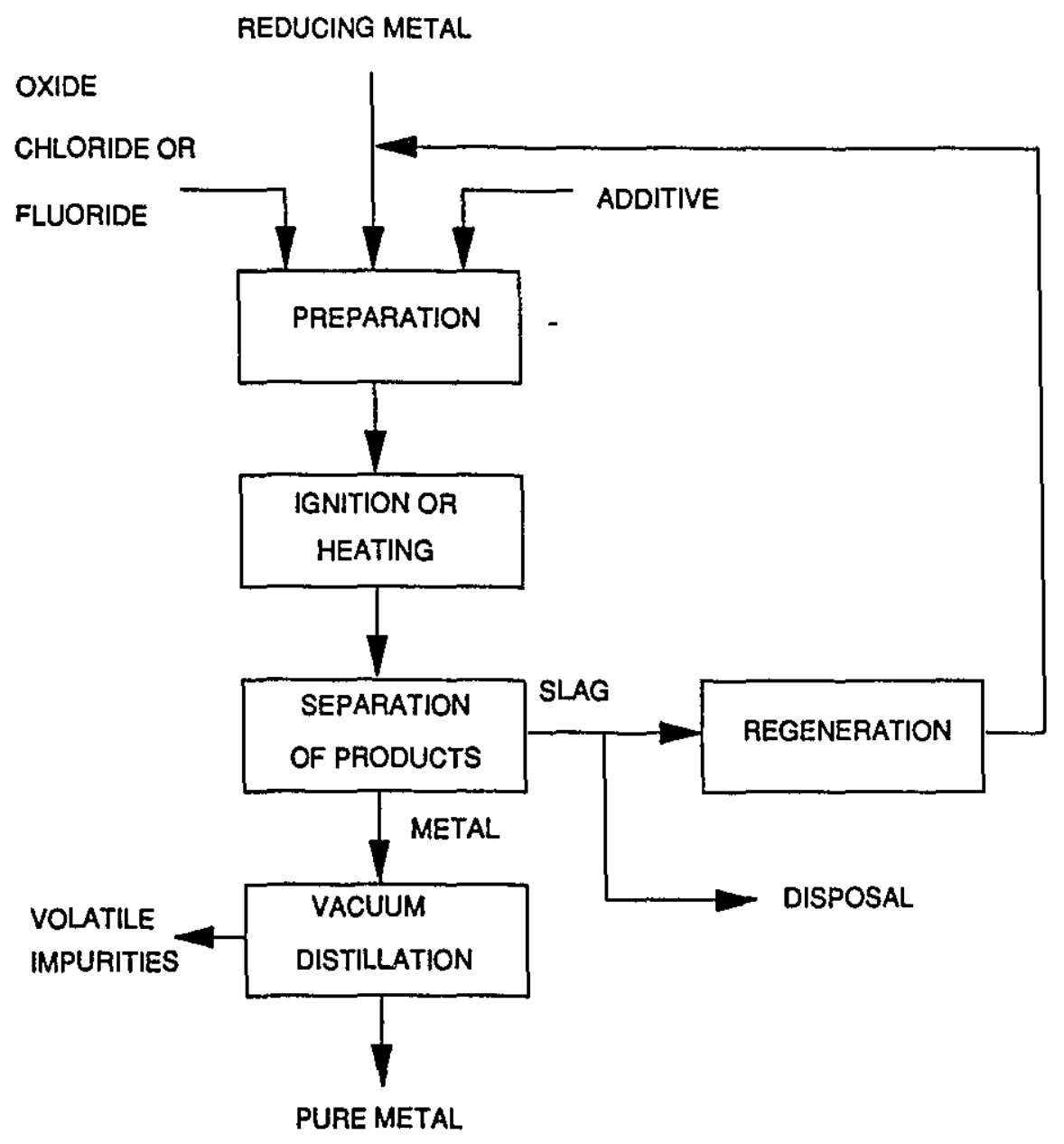

Figure 4 Schematic representation of solid-solid processing 


\section{II.2 STRONTIUM METAL PRODUCTION BY METALLOTHERMIC REDUCTION}

On an industrial scale, strontium is produced only by the thermal method under vacuum. This process, originally described by Guntz and Benoit ${ }^{(19 \times 20)(21)}$ permits the preparation of strontium by reduction of its oxide with aluminum powder. The most systematic investigation of the thermal process for the reduction of alkali metals was made by Gvalesian and Pazukhin ${ }^{(22)}$. In particular, they studied the influence of charge's composition, temperature, briquetting pressure and the size of the reducer on the extraction of $\mathrm{Ba}$ and $\mathrm{Sr}$.

Another process, known as the Pidgeon Process ${ }^{(23)}$ after its inventor, was developed commercially for the production of magnesium in Canada after World War II and has operated for about 30 years. This process has recently been displaced by the Magnetherm Process ${ }^{(23)(24)}$. A method similar to the Pidgeon Process is currently used in the production of strontium by Timminco Metals in Ontario, Canada. Equation 1 is the basis for today's process. Complete details on the actual strontium production route is unknown. However, the actual process could be schematically described by Figure 5 below.

The strontium production method is batch wise using powder reactants in a vacuum retort. The inherent disadvantages of the retorting process include high labour requirements and low production rates due to the slow heating and cooling of the vacuum retort and slow heat transfer into the solid reactants. 


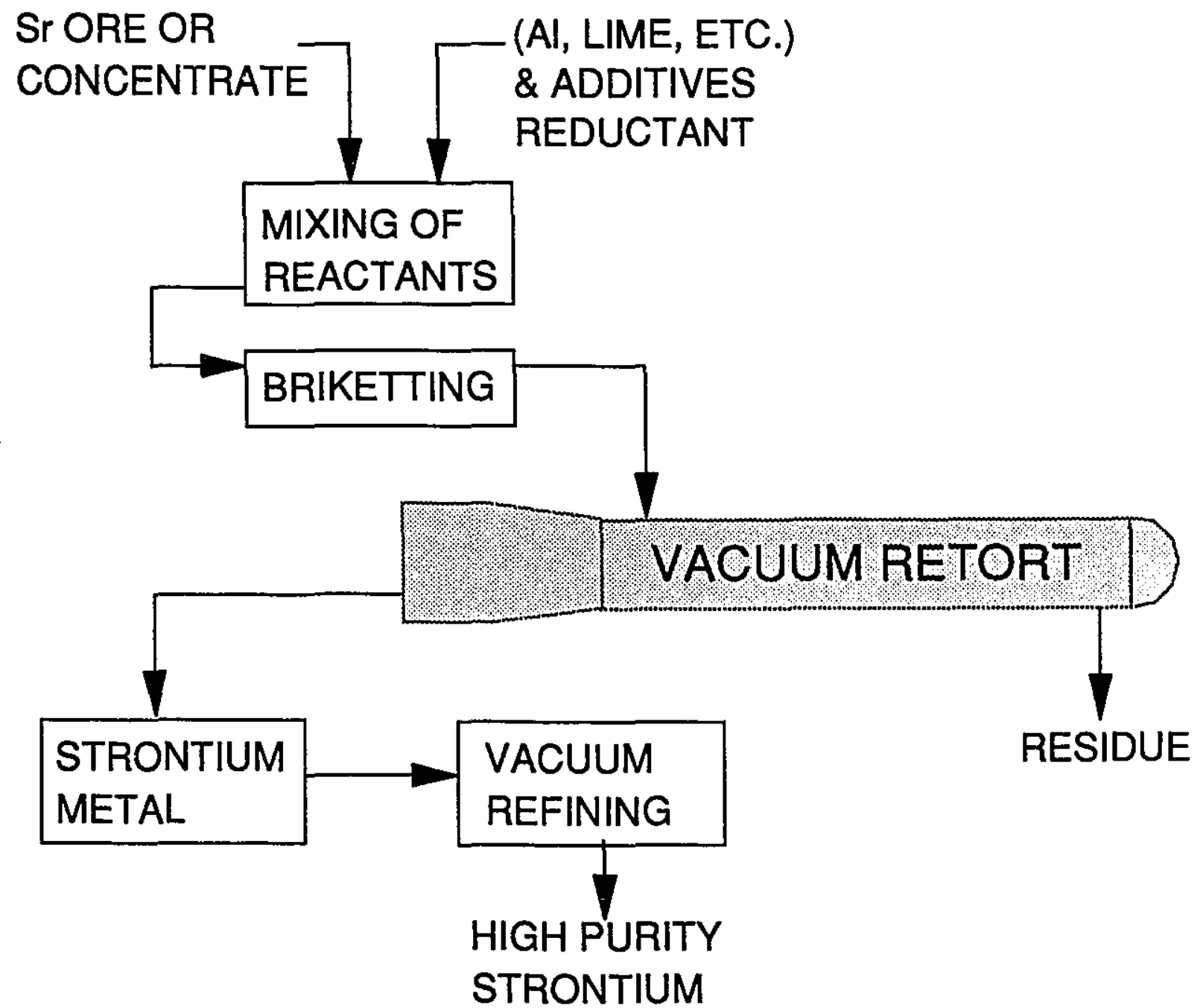

Figure 5 Schematic representation of the possible current strontium production method 


\section{II.3 STRONTIUM COMPOUNDS}

\section{I.3.1 Overview}

Nearly $75 \%{ }^{(13)}$ of strontium in U.S is consumed in the carbonate form by the ceramic and glass industries. Other compounds are mainly used in pyrotechnics, electronics and paint industries. Minor amounts of strontium compounds are used in electrolytic zinc manufacturing. Small quantities are consumed in greases, soaps, alloys and pharmaceuticals.

\section{II.3.2 Preparation}

Most uses of strontium require a compound in the form of the carbonate. Other salts are generally derived from the pure carbonate.

The Carbonate: They are many processes and variants existing for the production of strontium carbonate. However two basic processes for the carbonate production from the strontium sulfate ore are presented here. The starting material is generally a high grade celestite ore at $95 \% \mathrm{SrSO}_{4}$ or better. The ore is finely ground and incorporated to a hot solution of sodium carbonate. This slurry is then agitated and the following double reactions gradually take place.

$$
\mathrm{SrSO}_{4}+\mathrm{Na}_{2} \mathrm{CO}_{3} \rightarrow \downarrow \mathrm{SrCO}_{3}+\mathrm{Na}_{2} \mathrm{SO}_{4}
$$

The reactions taking place depend on many parameters such as: time, temperature and concentration. The precipitated carbonate containing impurities (iron, calcium, barium and silica) is then separated by conventional means, such as decantation, filtering and washing. Depending on the purity of the starting celestite material, reaction and washing efficiency, $\mathrm{SrCO}_{3}$ could assay 
92 percent or better. For uses where higher purity is required, the process may continue in order to obtain higher final product purity.

Another current method for the production of strontium carbonate commercially is the reduction method with carbon ${ }^{(25)}$. Celestite ore is crushed, ground and mixed with ground coke prior being conveyed to the kilns. In the kilns, the celestite is reduced to soluble strontium sulfide. The product, known as black ash, is the result of the following reaction.

$$
\mathrm{SrSO}_{4(s)}+2 \mathrm{C}_{(s)} \rightarrow \mathrm{SrS}_{(s)}+2 \mathrm{CO}_{2(8)}
$$

The soluble strontium sulfide produced is then dissolved in water. Undissolved solids are removed as muds by decantation and filtration. The muds are washed, centrifuged and discarded. The filtrate, a saturated solution of $\mathrm{SrS}$, is sent to a tank where soda ash is added to cause precipitation of strontium carbonate crystals by the following equation.

$$
S r S_{(l)}+\mathrm{Na}_{2} \mathrm{CO}_{3(s)} \rightarrow \mathrm{SrCO}_{3(s)}+\mathrm{Na}_{2} \mathrm{~S}_{(l)}
$$

Depending on the original purity of the celestite ore, reaction and washing efficiencies, a final product analyzing $92 \%$ or better $\mathrm{SrCO}_{3}$ can be obtained. Higher strontium purity can be obtained by dissolving the undried $\mathrm{SrCO}_{3}$ filter cake with hydrochloric acid. The strontium chloride solution is then treated with necessary reagents to precipitate soluble impurities, such as calcium, barium, iron and aluminum. The solution is filtered to separate the impurities from the solution. Carbonation is then performed with soda ash followed by washing, filtering, drying and grinding to a fine powder. The final carbonate analyzes $99 \% \mathrm{SrCO}_{3}$ or better.

From the pure strontium carbonate, other strontium salts are prepared by reacting it with the acid of the desired salt. Strontium nitrate for example is produced directly from the crude 
carbonate by reacting it with nitric acid followed by filtration of the crystallized precipitate.

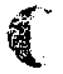




\section{II.4. THE CARBONATE}

\section{II.4.1 Introduction}

Some of the orthorhombic carbonates are aragonite, which is a common polymorph of calcium carbonate $\left(\mathrm{CaCO}_{3}\right)$, and the rarer isomorphs, strontianite $\left(\mathrm{SrCO}_{3}\right)$, witherite $\left(\mathrm{BaCO}_{3}\right)$, and cerussite $\left(\mathrm{PbCO}_{3}\right)$. These minerals played important roles in the discovery of polymorphism and isomorphism ${ }^{(26)}$ by Mitscherlich in 1822 and Wollaston in 1812, respectively.

Many studies on orthorhombic carbonates yield information on the temperatures and pressures of crystallization, fluid chemistry, source material and isotopic age.

\section{II.4.2 Crystallography}

The carbonate ion is a well-defined entity in which the three oxygens are arranged in the same plane with the carbon atom, Figure 6. The distance between the oxygen and carbon is 1.30 $\pm 0.01 \AA$ with a bond angle of $120^{\circ}$. This value of the $\mathrm{C}-\mathrm{O}$ distance was calculated by Pauling ${ }^{(27)}$ on the basis of the resonance structures.

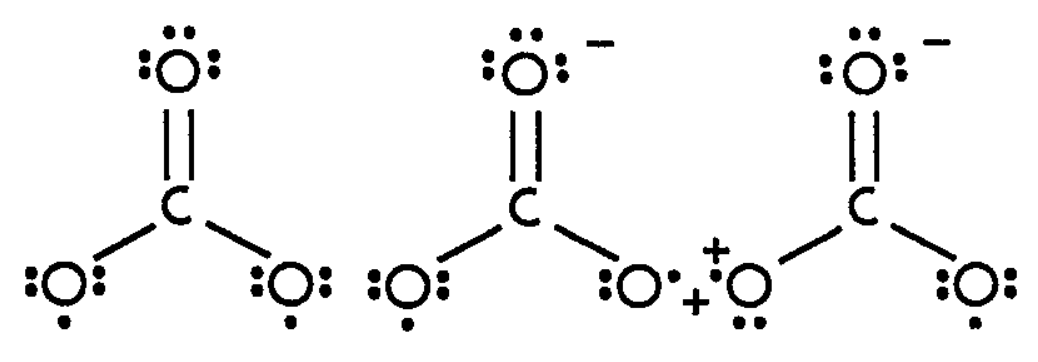

Figure 6 Schematic representation of the carbonate ion structure 
The resonance energy is $176 \mathrm{~kJ}(42 \mathrm{kcal})$ per mole. The orthorhombic carbonate, strontianite undergoes polymorphic transitions at high temperatures and pressures. Strontianite $\left(\gamma-\mathrm{SrCO}_{3}\right)$ transforms to a disordered calcite (rhombohedral, $\left.\beta-\mathrm{SrCO}_{3}\right)$ structure at elevated temperature. The transition temperature for strontianite has been reported at $930^{\circ} \mathrm{C}$ by Rapoport and Pistorius ${ }^{(2)}$ in 1967 and can be expressed as

$$
T\left({ }^{\circ} \mathrm{C}, \mathrm{SrCO}_{3}\right)-930+9.10 P+0.0081 P^{2}-0.00135 P^{3}
$$

where $\mathrm{P}$ is in kilobars. At higher temperatures $\left(1416^{\circ} \mathrm{C}\right)$, the rhombohedral phase of $\mathrm{SrCO}_{3}$ undergoes a cubic phase transition.

\section{II.4.3 Summary of Carbonate Decomposition}

The term decomposition applies to a chemical process and is used, in general, to signify the breakdown of one or more constituents of the reactant into simpler atomic groupings. Decomposition processing implying a temperature increase is known as thermal decomposition. Decomposition of all carbonates results in the evolution of $\mathrm{CO}_{2}$. The decomposition product is the corresponding oxice or a basic carbonate which decomposes with further evolution of $\mathrm{CO}_{2}$ as the temperature is raised. The oxides of some metals are unstable in the same temperature range of the corresponding carbonates. Therefore, the decomposition takes place according to the following reaction,

$$
\mathrm{MCO}_{3}=\mathrm{MO}+\mathrm{CO}_{2(8)}
$$


where $\mathrm{M}$, represents the metallic element. However, if the carbonates and oxide coexist as pure solid, the decomposition is generally quit simple. The reaction is described by the overail stoichiometry (e.g., $\mathrm{MCO}_{3}=\mathrm{MO}+\mathrm{CO}_{2}$ ) and the equilibrium pressure of $\mathrm{CO}_{2}$ is a function of temperature only. The dissociation of $\mathrm{SrCO}_{3}$ at a temperature of $1270^{\circ} \mathrm{C}$ and a carbon dioxide partial pressure of 1.12 atmosphere would result in the fusion of the oxide (SrO) and the remaining carbonate. However, the decomposition of strontium carbonate below this temperature and pressure would yield to the formation of strontium oxide (SrO) plus carbon dioxide $\left(\mathrm{CO}_{2}\right)$. 


\section{II.5 INTERFACIAL PHENOMENA}

The surface property with the most extensive technical significance is that of wetting. The MLE process, the subject of investigation in this thesis, involves solid/liquid interaction implying surface chemistry and wetting. The chemical rates of reaction depend on the nature of the interfaces and the mechanisms of the reaction while the transport rates to and from the interfaces are determined by flow and mixing in the two phases. Therefore, without good wetting, the chemical and the transport rates are greatly reduced. In the extreme case where the wetting between the solid oxide and the liquid reductant is non-existant, reaction would simply not occur.

\section{II.5.1 Surface Tensions of Metals}

The surface tensions of liquid metals are high; typical values are listed in Table VII. For comparison, the surface tension for water at $20^{\circ} \mathrm{C}$ is 72 dyne $\mathrm{cm}^{-1}$ while values ranging from 17 to 45 dyne $\mathrm{cm}^{-1}$ are observed for most organic liquids. Many solutes in liquid metals can act as surface active agents (corresponding to soaps in water) which lower the surface tension. Measurement of the contact angle, $\theta$, is the most generally applicable technique to determine the wetting between solid and liquid. The contact angle, $\theta$, is always measured in the liquid phase,

Figure 7. When the liquid phase sits as a near-spherical droplet on the solid surface, $\theta$ is large, and in the limit reaches $180^{\circ}$. If the liquid phase tends to wet the solid surface, $\theta$ then is small and in the limit reaches $0^{\circ}$. 
Table VII Typical Surface Tension for Metals, $\boldsymbol{\gamma}_{L G}$

\begin{tabular}{||l|c|r|r||}
\hline Metal & Atomic Number & $\begin{array}{r}\text { Melting Point } \\
\left({ }^{\circ} \mathrm{C}\right)\end{array}$ & $\begin{array}{c}\gamma_{\text {Lo }} \\
(\text { dyne/cm })\end{array}$ \\
\hline Lithium & 3 & 180 & 398 \\
Sodium & 11 & 98 & 191 \\
Iron & 26 & 1537 & 1872 \\
Zinc & 30 & 420 & 782 \\
Silver & 47 & 961 & 903 \\
Tin & 50 & 232 & 544 \\
Barium & 56 & 714 & 277 \\
Gold & 79 & 1063 & 1140 \\
Mercury & 80 & -38 & 498 \\
Lead & 82 & 327 & 468 \\
\hline
\end{tabular}

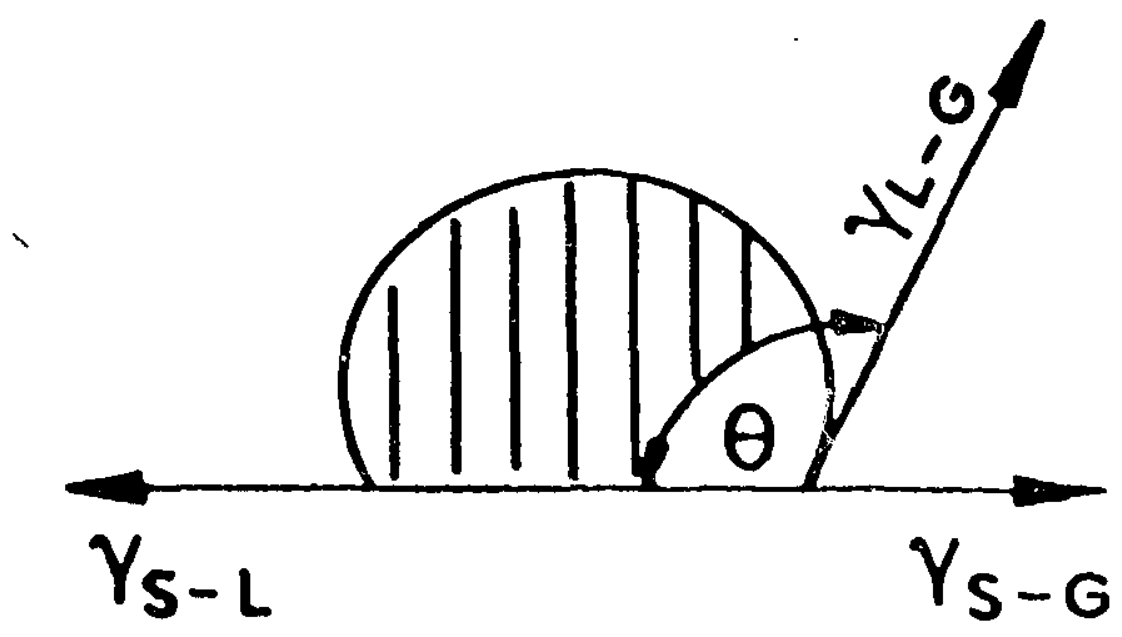

Figure 7 Contact Angle 
The two limits represent the conditions for complete non-wetting and complete wetting respectively. Suppose that a liquid, $\mathrm{L}$, rests on a solid surface, $\mathrm{S}$, in contact with an inert gas, G. At equilibrium, the liquid drop and the solid surface will meet at an angle $\theta$, such that

$$
\gamma_{S G}=\gamma_{S L}+\gamma_{L G} \cos \theta
$$

where, $\gamma_{S G}, \gamma_{S L}$ and $\gamma_{L G}$ are the surface tension between solid and gas, solid and liquid and liquid and gas respectively. Therefore, the theoretical contact angle can be expressed by the following equation;

$$
\cos \theta=\left[\frac{\gamma_{S G}-\gamma_{S L}}{\gamma_{L G}}\right]
$$

Using this equation, the contact angle between a solid with either liquid aluminum, aluminum-magnesium alloy or aluminum-bismuth alloy can be compared. Taking $\gamma_{s G}$ as constant, Equation (10) may be rewritten as follows;

$$
\cos \theta=\left[\frac{\gamma_{S G}-f\left(\gamma_{S L}\right)}{\gamma_{L G}}\right]
$$

Selected surface tension values for liquid metals are listed in Table VIII.

The surface tension, $\gamma_{S L}$, varies proportionally with the surface tension, $\gamma_{L G}$. Therefore, by increasing $\gamma_{L G}$, the contact angle, $\theta$, also increases. Lower contact angle implies better wetting of the solid surface. Figure 8, shows the effects of solute metals on the surface tension, $\gamma_{L G}$, of aluminum. If the wetting process reflects a reduction of an oxide film, the presence of metals dissolved in aluminum which have a greater affinity for oxygen than aluminum would 
Table VIII Selected Surface Tension Values

\begin{tabular}{|l|c|c|}
\hline Metal & $\begin{array}{c}\gamma_{\mathrm{LO}} \\
\text { (dyne/cm) }\end{array}$ & $\begin{array}{c}\gamma_{\text {sL }} \\
\text { (dyne/cm) }\end{array}$ \\
\hline Magnesium & 559 & 56 \\
Aluminum & 914 & 91 \\
Silicon & 865 & 86 \\
Calcium & 361 & 36 \\
Strontium & 303 & 30 \\
Bismuth & 378 & 38 \\
\hline
\end{tabular}

decreases the surface tension, $\gamma_{L G}$, of aluminum.

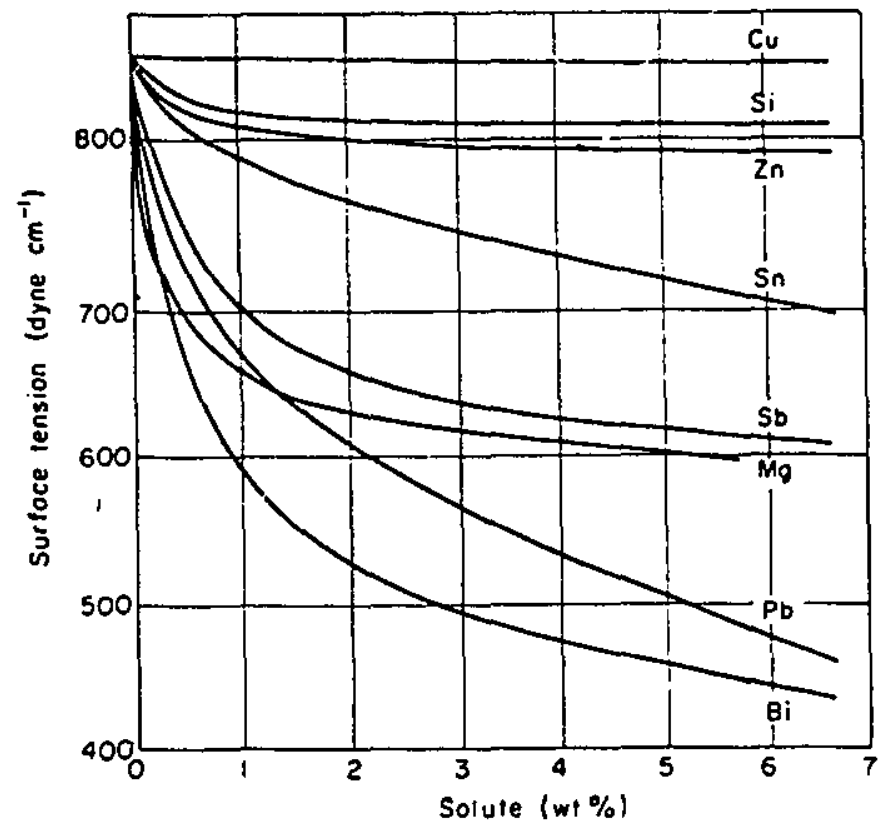

Figure 8 Surface tensions for aluminum with solute metals at 50 to $80{ }^{\circ} \mathrm{C}$ above the liquidus ${ }^{(28)}$

The values of surface tension which were obtained during the experimental program by magnesium and bismuth additions to the liquid $\mathrm{Al}$ are listed in Table IX and can be seen to be less than that for pure aluminum. Therefore, magnesium and bismuth improve the wetting between solids and the liquid metal. Moreover, magnesium has a greater oxygen affinity than aluminum and thus possibly reduces or at least interacts with the impervious aluminum oxide 
Table IX Surface Tension Values for each Experiment

\begin{tabular}{|c|c|c|c|c|c|c|}
\hline Exp. \# & $\begin{array}{c}\text { Metal } \\
\text { Addition }\end{array}$ & $\begin{array}{c}\text { Mg:Sr } \\
\text { Molar } \\
\text { Ratio }\end{array}$ & $\begin{array}{c}\text { Mg Add. } \\
\text { (wt\%) }\end{array}$ & $\begin{array}{c}\text { Bi:Sr } \\
\text { Molar } \\
\text { Ratio }\end{array}$ & $\begin{array}{c}\text { Bi Add. } \\
\text { (wt\%) }\end{array}$ & $\begin{array}{c}\gamma_{\text {LG }} \\
\text { (dyne/cm) }\end{array}$ \\
\hline 0 & - & - & - & - & - & 860 \\
1 & $\mathrm{Mg}$ & 2 & 1.8 & - & - & 640 \\
2 & $\mathrm{Mg}$ & 4 & 3.5 & - & - & 610 \\
3 & $\mathrm{Mg}$ & 6 & 5.1 & - & - & 600 \\
4 & $\mathrm{Mg}$ & 8 & 6.7 & - & - & $590^{(6)}$ \\
5 & $\mathrm{Mg}$ & 10 & 8.3 & - & - & $580^{(6)}$ \\
6 & $\mathrm{Bi}$ & - & - & 0.13 & 1 & 590 \\
7 & $\mathrm{Bi}$ & - & - & 0.39 & 3 & 495 \\
8 & $\mathrm{Bi}$ & - & - & 0.78 & 6 & 440 \\
\hline \multicolumn{7}{|l}{} \\
\hline
\end{tabular}

film on its surface thereby improving wetting. Figure 9, shows a schematic representation in which the impervious aluminum oxide layer was reduced by magnesium contained in the molten reductant. The strontium oxide could then be reduced by the molten reductant and "freely" dissolve in it. 


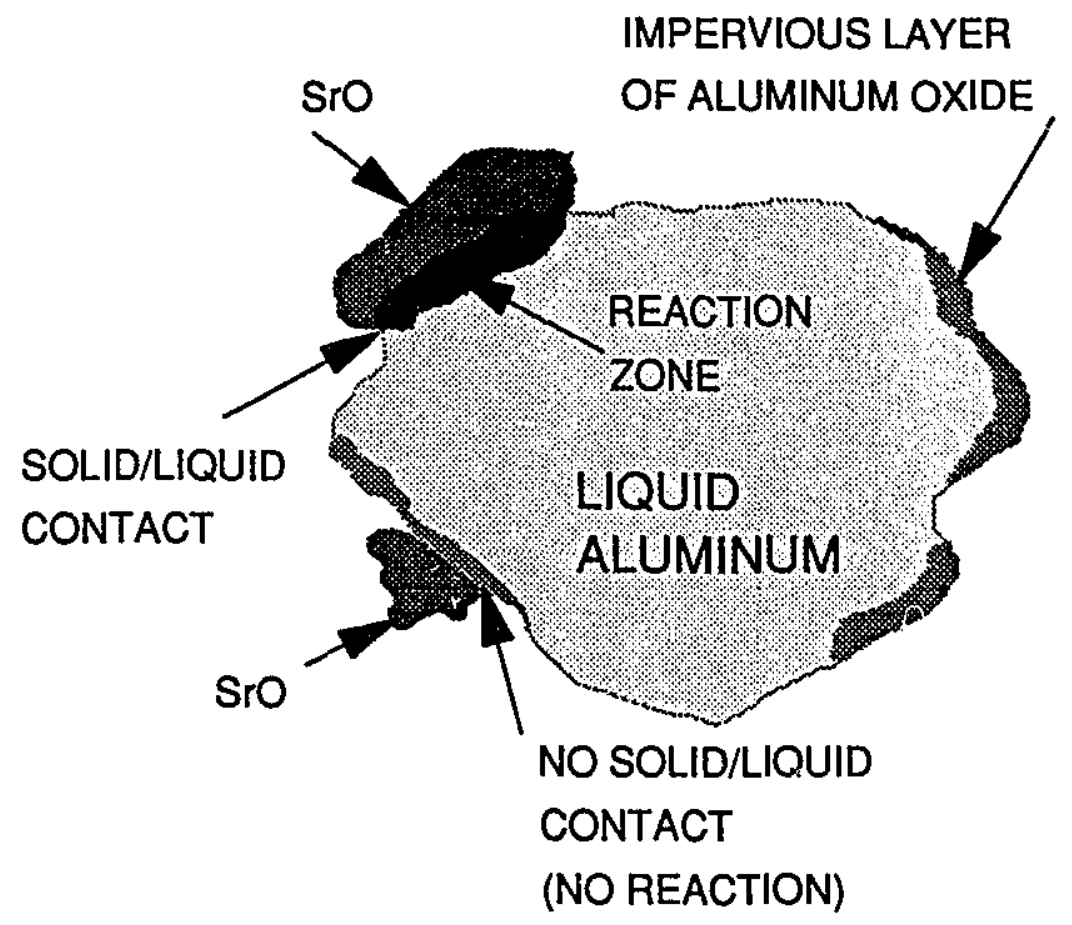

Figure 9 Schematic of the Possible Reaction Mechanism with Magnesium present in the Aluminum Reductant 


\section{PHYSICAL PROPERTIES OF THE METALS OF CONCERN}

\section{TO THIS WORK (Al, $\mathrm{Mg}, \mathrm{Sr}$ and $\mathrm{Bi})$}

\section{III.1 PHYSICAL PROPERTIES OF LIQUID ALUMINUM}

There is no generally fixed nomenclature for the various degrees of purity of aluminum. However, the following classification is appropriate, Table $\mathbf{X}$.

Table X Classification of Pure Aluminum ${ }^{(29)}$

\begin{tabular}{||c|c|}
\hline Aluminum (\%) & Designation \\
\hline $99.50-99.79$ & Commercial Purity \\
$99.80-99.949$ & High Purity \\
$99.95-99.9959$ & Super Purity \\
$99.9960-99.9990$ & Extreme Purity \\
Over 99.9990 & Ultra Purity \\
\hline
\end{tabular}

The following properties are concerned with aluminum of $99.95 \%$ purity or greater.

\section{III.1.1 Density}

The theoretical density, based on lattice spacing, is $2698.72 \mathrm{~kg} / \mathrm{m}^{3}$. The density of molten aluminum at a particular temperature may be determined by the following equation:

$$
\rho_{T}=\rho_{m}+\left[T-T_{m}\right]\left[\frac{\partial \rho}{\partial T}\right]
$$


where $\rho_{m}$ : Density at melting point, $\mathrm{g} / \mathrm{cm}^{3}$

$\rho_{\mathrm{T}}$ : Density at a higher temperature

The value of $\rho_{\mathrm{m}}$ given by Smithells $\mathrm{s}^{(30)}$ is $2.385 \mathrm{~g} / \mathrm{cm}^{3}$ for molten aluminum and the value $\partial \rho / \partial T$ is given as $-2.8 \times 10^{-4} \mathrm{~g} / \mathrm{cm}^{3} \cdot \mathrm{K}$. The densities of pure molten aluminum at various temperatures are presented in Table XI.

Table XI Density of Liquid Aluminum versus Temperature

\begin{tabular}{|c|c|}
\hline Temperature $(\mathrm{K})$ & $\rho\left(\mathrm{g} / \mathrm{cm}^{3}\right)$ \\
\hline $933.25(\mathrm{mp})$ & 2.385 \\
950 & 2.380 \\
1000 & 2.366 \\
1050 & 2.352 \\
1100 & 2.338 \\
1150 & 2.324 \\
1200 & 2.310 \\
1250 & 2.296 \\
1273 & 2.290 \\
\hline
\end{tabular}

\section{III.1.2 Surface Tension}

The surface tension, $\sigma$, of most liquids may be represented over temperature ranges by the linear equation

$$
\sigma_{T}=\sigma_{m}+\left[T-T_{m}\right]\left[\frac{\partial \sigma}{\partial T}\right]
$$


where $\sigma_{\mathrm{m}}:$ Surface tension at melting point, $\mathrm{N} / \mathrm{m}$

$\sigma_{\mathrm{T}}:$ Surface tension at a higher temperature

The value of $\sigma_{\mathrm{m}}$ given by Smithells ${ }^{(30)}$ is $9.14 \times 10^{-1} \mathrm{~N} / \mathrm{m}$ and the value for $\partial \sigma / \partial T$ is given as $-3.5 \times 10^{-4} \mathrm{~N} / \mathrm{m} \cdot \mathrm{K}$. Some values of the aluminum surface tension versus temperature are listed in Table XII.

Table XII Surface Tension of Liquid Aluminum versus Temperature

\begin{tabular}{|c|c|c|}
\hline Temperature $(\mathrm{K})$ & $\sigma(\mathrm{N} / \mathrm{m})$ & $\sigma$ (dyne/cm) \\
\hline $933.25(\mathrm{mp})$ & 0.914 & 914 \\
950 & 0.908 & 908 \\
1000 & 0.891 & 891 \\
1050 & 0.873 & 873 \\
1100 & 0.856 & 856 \\
1150 & 0.838 & 838 \\
1200 & 0.821 & 821 \\
1250 & 0.803 & 803 \\
1273 & 0.795 & 795 \\
\hline
\end{tabular}

\section{III.1.3 Vapour Pressure}

JANAF tables suggest a boiling point for aluminum of $2767 \mathrm{~K}$ and a heat of vaporization equal to $69.5 \mathrm{kcal} / \mathrm{mole}$ for the determination of the aluminum vapour pressure. Thermochemical data, on liquid and gaseous aluminum, yield the calculated values shown in Table XIII. 
Table XIII Vapour Pressure of Liquid Aluminum

\begin{tabular}{|c|c|}
\hline Temperature (K) & Vapour Pressure (atm) \\
\hline $933.25(\mathrm{mp})$ & $6.52 \mathrm{E}-12$ \\
1000 & $7.4 \mathrm{E}-11$ \\
1200 & $3.7 \mathrm{E}-08$ \\
1273 & $2.4 \mathrm{E}-07$ \\
1400 & $3.0 \mathrm{E}-06$ \\
1600 & $7.8 \mathrm{E}-05$ \\
1800 & $9.8 \mathrm{E}-04$ \\
2200 & 0.007 \\
2200 & 0.037 \\
2400 & 0.143 \\
2600 & 0.442 \\
2700 & 0.728 \\
\hline
\end{tabular}




\section{III.2 PHYSICAL PROPERTIES OF LIQUID STRONTIUM}

The density and the surface tension of the liquid strontium are determined in a region of high temperature between the melting point $768^{\circ} \mathrm{C}$ and $1000^{\circ} \mathrm{C}$.

\section{III.2.1 Density}

The equation for the density of liquid strontium varying with temperature is given by Equation $14^{(31)}$. The change in density with temperature is listed in Table XIV.

$$
\rho=2.648-2.62 \times 10^{-4} T
$$

where $\rho:$ Density, $\mathrm{g} / \mathrm{cm}^{3}$

$\mathrm{T}:$ Temperature, $\mathrm{K}$

Table XIV Density of Liquid Strontium vs. Temperature

\begin{tabular}{|c|c|}
\hline Temperature (K) & $\rho\left(\mathrm{g} / \mathrm{cm}^{3}\right)$ \\
\hline $1041(\mathrm{mp})$ & 2.38 \\
1050 & 2.37 \\
1100 & 2.36 \\
1150 & 2.35 \\
1200 & 2.33 \\
1250 & 2.32 \\
1273 & 2.31 \\
\hline
\end{tabular}




\section{III.2.2 Surface Tension}

Data found in literature on the surface tension of molten strontium differ rather significantly. The values given here were taken over a larger temperature interval ${ }^{(31)}$ and may allow a better determination of the temperature coefficients of the measured properties. The surface tension is given by the following equation ${ }^{(31)}$ and values are listed in Table XV.

$$
\sigma=392-0.085 T
$$

where $\sigma:$ Surface Tension, dyne/cm

$\mathrm{T}$ : Temperature, $\mathrm{K}$

Table XV Surface Tension of Liquid Strontium vs. Temperature

\begin{tabular}{|c|c|}
\hline Temperature $(\mathrm{K})$ & $\sigma($ dyne/cm) \\
\hline $1041(\mathrm{mp})$ & 304 \\
1050 & 303 \\
1100 & 299 \\
1150 & 294 \\
1200 & 290 \\
1250 & 286 \\
1273 & 284 \\
\hline
\end{tabular}

\section{III.2.3 Vapour Pressure}

The vapour pressure can be calculated for a large temperature range between the melting point and the boiling point using the Equation $16^{(30)}$. The Table XVI presents the strontium 
vapour pressure variation with temperature. The list includes the melting temperature and the experimental temperature (1273 K).

$$
\log P=-\frac{9000}{T}-1.31 \log T+12.63
$$

Table XVI Vapour Pressure of Liquid Strontium

\begin{tabular}{|c|c|}
\hline Temperature (K) & Vapour Pressure (atm) \\
\hline $1041(\mathrm{mp})$ & $1.42 \mathrm{E}-03$ \\
1050 & $1.66 \mathrm{E}-03$ \\
1100 & $3.83 \mathrm{E}-03$ \\
1150 & $8.20 \mathrm{E}-03$ \\
1200 & $1.64 \mathrm{E}-02$ \\
1250 & $3.11 \mathrm{E}-02$ \\
1273 & $4.09 \mathrm{E}-02$ \\
\hline
\end{tabular}




\section{III.3 PHYSICAL PROPERTIES OF LIQUID MAGNESIUM}

\section{III.3.1 Density}

The equation for the liquid magnesium density versus temperature is given below ${ }^{(32)}$.

$$
\rho=1.834-2.647 \times 10^{-4} T
$$

where $\rho$ : Density, $\mathrm{g} / \mathrm{cm}^{3}$

$\mathrm{T}$ : Temperature, $\mathrm{K}$

The error is said to be in the range of $\pm 0.0014 \mathrm{~g} / \mathrm{cm}^{3}$. The density change with temperature for liquid magnesium is listed in Table XVII.

Table XVII Density of Liquid Magnesium versus Temperature

\begin{tabular}{|c|c|}
\hline Temperature $(\mathrm{K})$ & $\rho\left(\mathrm{g} / \mathrm{cm}^{3}\right)$ \\
\hline $922(\mathrm{mp})$ & 1.590 \\
950 & 1.583 \\
1000 & 1.569 \\
1100 & 1.543 \\
1200 & 1.516 \\
1273 & 1.503 \\
\hline
\end{tabular}

\section{III.3.2 Surface Tension}

The surface tension of magnesium obeys the following formula ${ }^{(11)}$. 


$$
\sigma=721-0.149 T
$$

where $\sigma:$ Surface Tension, $\mathrm{erg} / \mathrm{cm}^{2}$

$\mathrm{T}$ : Temperature, $\mathrm{K}$

The change in magnesium surface tension with temperature is shown in Table XVIII.

Table XVIII Surface Tension of Magnesium versus Temperature

\begin{tabular}{|c|c|}
\hline Temperature (K) & $\sigma($ dyne/cm) \\
\hline $922(\mathrm{mp})$ & 584 \\
950 & 579 \\
1000 & 572 \\
1100 & 557 \\
1200 & 542 \\
1273 & 531 \\
\hline
\end{tabular}

\section{III.3.3 Vapour Pressure}

The vapour pressure for magnesium is calculated using Equation $19^{(30)}$. The calculated values cover a range of temperature, Table XIX, between the melting point and the experimental temperature used for the reduction process $(1273 \mathrm{~K})$.

$$
\log P=-\frac{7550}{T}-1.41 \log T+12.79
$$


Table XIX Vapour Pressure of Liquid Magnesium

\begin{tabular}{|c|c|}
\hline Temperature (K) & Vapour Pressure (atm) \\
\hline $922(\mathrm{mp})$ & $3.47 \mathrm{E}-03$ \\
950 & $5.80 \mathrm{E}-03$ \\
1000 & $1.35 \mathrm{E}-02$ \\
1100 & $5.72 \mathrm{E}-02$ \\
1200 & $1.89 \mathrm{E}-01$ \\
1273 & $3.99 \mathrm{E}-01$ \\
\hline
\end{tabular}




\section{III.4 PHYSICAL PROPERTIES OF LIQUID BISMUTH}

\section{III.4.1 Density}

The density of molten bismuth can be calculated according to an equation of the same form as that used for liquid aluminum i.e., Equation 12. Values for $\rho_{\mathrm{m}}$ and $\partial \rho / \partial T$ are 10.068 $\mathrm{g} / \mathrm{cm}^{3}$ and $-1.33 \times 10^{-3} \mathrm{~g} / \mathrm{cm}^{3} \cdot \mathrm{K}$, respectively. Table XX shows the density of liquid bismuth change with temnerature.

Table XX Density of Liquid Bismuth versus Temperature

\begin{tabular}{|c|c|}
\hline Temperature $(\mathrm{K})$ & $\rho\left(\mathrm{g} / \mathrm{cm}^{3}\right)$ \\
\hline $544.42(\mathrm{mp})$ & 10.068 \\
600 & 9.994 \\
700 & 9.861 \\
800 & 9.728 \\
900 & 9.595 \\
1000 & 9.462 \\
1100 & 9.329 \\
1273 & 9.099 \\
\hline
\end{tabular}

\section{III.4.2 Surface Tension}

Using a similar equation as that for aluminum (Equation 13), the surface tension of liquid bismuth can be calculated using the appropriate values for $\sigma_{\mathrm{m}}$ and $\partial \sigma / \partial T$. Their values, given by Smithells, are $3.78 \times 10^{-1} \mathrm{~N} / \mathrm{m}$ and $-7 \times 10^{-5} \mathrm{~N} / \mathrm{m} \cdot \mathrm{K}$, respectively. Table XXI shows the effect 
of temperature on the surface tension of liquid bismuth.

Table XXI Surface Tension of Liquid Bismuth versus Temperature

\begin{tabular}{|c|c|c|}
\hline Temperature $(\mathrm{K})$ & $\sigma(\mathrm{N} / \mathrm{m})$ & $\sigma$ (dyne/cm) \\
\hline $544.52(\mathrm{mp})$ & 0.378 & 378 \\
600 & 0.374 & 374 \\
700 & 0.367 & 367 \\
800 & 0.360 & 360 \\
900 & 0.353 & 353 \\
1000 & 0.346 & 346 \\
1100 & 0.339 & 339 \\
1273 & 0.327 & 327 \\
\hline
\end{tabular}

\section{III.4.3 Vapour Pressure}

The Equation $20^{(30)}$ was used to determine the change of the bismuth vapour pressure with temperature. The calculated values are listed in Table XXII below.

$$
\log P=-\frac{10400}{T}-1.26 \log T+12.35
$$


Table XXII Vapour Pressure of Liquid Bismuth

\begin{tabular}{|c|c|}
\hline Temperature $(\mathrm{K})$ & Vapour Pressure (atm) \\
\hline $544.52(\mathrm{mp})$ & $8.36 \mathrm{E}-14$ \\
600 & $4.32 \mathrm{E}-12$ \\
700 & $1.06 \mathrm{E}-09$ \\
800 & $6.48 \mathrm{E}-08$ \\
900 & $1.55 \mathrm{E}-06$ \\
1000 & $1.95 \mathrm{E}-05$ \\
1100 & $1.52 \mathrm{E}-04$ \\
1273 & $2.44 \mathrm{E}-03$ \\
\hline
\end{tabular}




\section{THERMODYNAMIC SIMULATION OF $\mathrm{SrCO}_{3}$ REDUCTION}

The first step concerning metallothermic reduction, is the choice of the metal reductant. The choice of the reductant can be simplified by using the Ellingham Diagram, Figure 10. The diagram gives the Standard Gibbs energy of formation of metal oxides as a function of temperature. From experience of industrial metallothermic reduction processes, aluminum appears to have been the best choice. Nevertheless, the choice of a particular metal reductant should take into account the following:

a) The metal should have a strong affinity for oxygen. Based on thermodynamic considerations, aluminum, silicon, calcium and magnesium are the most suitable for reducing oxides.

b) The metal should be easily obtained at high purity and at low cost. This requirement is satisfied by aluminum, magnesium and sodium. High purity silicon and calcium are expensive.

c) The metal should have a high boiling point for temperature and pressure flexibility.

d) The metal should be easy to handle (no need of inert atmosphere). 


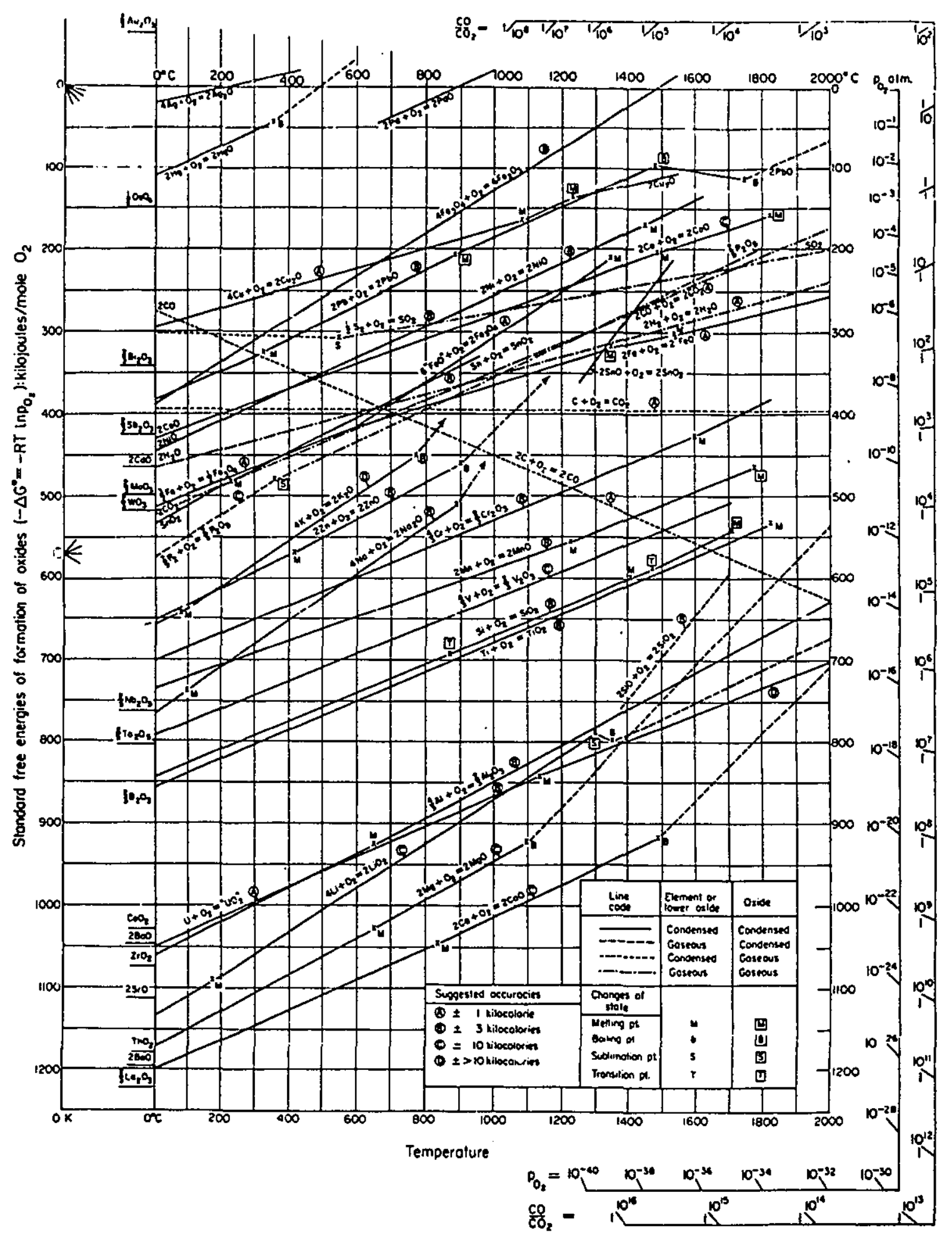

Figure 10 Ellingham Diagram ${ }^{(33)}$ 
Table 22 shows some properties of strontium and possible metal reductant.

Table XXII Strontium and Metal Reductant Properties

\begin{tabular}{|c|c|c|c|c|c|}
\hline & \multicolumn{5}{|c|}{ METAL } \\
\hline PROPERTY & $\mathrm{Sr}$ & $\mathrm{Al}$ & $\mathrm{Mg}$ & $\mathrm{Ca}$ & $\mathrm{Si}$ \\
\hline MELTING PONNT $\left(^{\circ} \mathrm{C}\right)$ & 768 & 660 & 649 & 839 & 1412 \\
BOILING POING $\left({ }^{\circ} \mathrm{C}\right)$ & 1377 & 2520 & 1090 & 1484 & 3267 \\
PRICE (CAN \$ $/ \mathrm{kg})$ & 26 & 1.69 & 3.61 & 9.75 & 1.63 \\
\hline
\end{tabular}

The Ellingham Diagram shows that aluminum and silicon are not suitable for the reduction of strontium oxide at unit activities and ambient pressure. Calcium and magnesium could reduce strontium oxide but they cannot be used as a bulk metal due to the cost, reactivity and high vapour pressure. Therefore, the addition of a solute metal such as $\mathrm{Mg}$ or $\mathrm{Ca}$ into an alloy with aluminum would increase the overall oxygen affinity of the melt and this aluminum alloy would be an ideal reducing agent for the reduction of strontium oxide for the following reasons:
a) Low Cost
b) Low Melting Point
c) High Boiling Point
d) Low Vapour Pressure

The results of a thermodynamic simulation of the $\mathrm{SrCO}_{3}$ reduction using $\mathrm{F}^{*} \mathrm{~A}^{*} \mathrm{C}^{*} \mathrm{~T}^{(34)}$ 
considering $\mathrm{Mg}$ and $\mathrm{Ca}$ in an alloy mixture with aluminum are summarized in Figure 11. The prediction shows that magnesium additions are thermodynamically superior to calcium additions for the reduction of $\mathrm{SrCO}_{3}$. The figure also includes strontium extraction with $\mathrm{Na}$ additions for purposes of comparison.

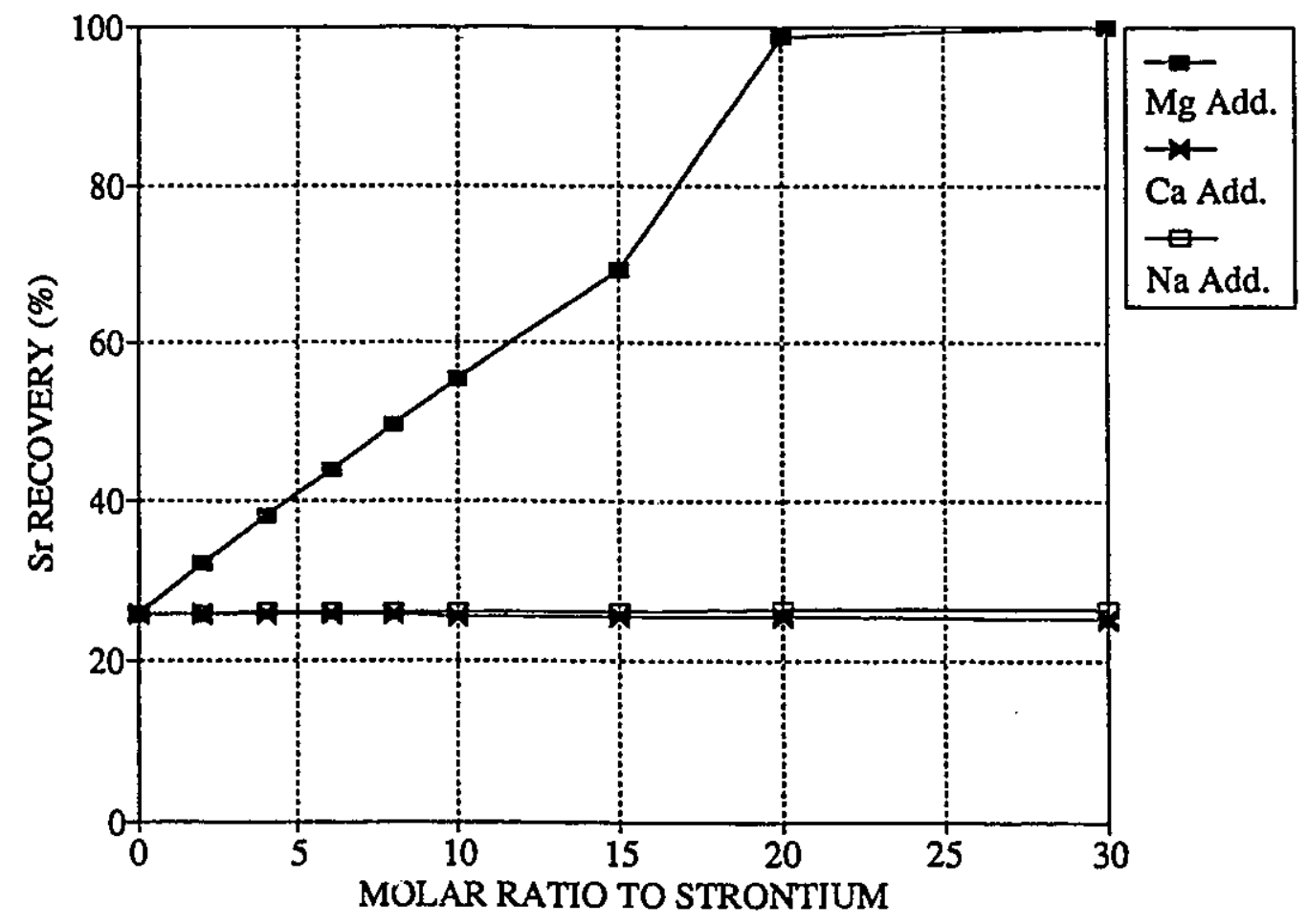

Figure 11 Strontium Extraction with $\mathrm{Mg}, \mathrm{Ca}$ and $\mathrm{Na}$ Additions

In the simulation, the $\mathrm{F}^{*} \mathrm{~A}^{*} \mathrm{C}^{*} \mathrm{~T}$ thermodynamic database which was used to perform the thermodynamic calculations includes many subroutines. The EQUILIB routine, used for heterogeneous equilibrium calculations, predicts the most stable compounds formed from reaction of specific reactants at a certain temperature and pressure. EQUILIB was used to simulate strontium carbonate reduction by an aluminum alloy containing either magnesium, calcium, sodium or bismuth. Thermodynamic data for dissolved species was obtained and included in the 
$\mathrm{F}^{*} \mathrm{~A}{ }^{*} \mathrm{C}^{*} \mathrm{~T}$ database using the DATAENTRY routine. The data needed included the free energy of dissolution in liquid aluminum of the dissolved metallic species. Table XXIII shows the data used to create the private data base.

Table XXIII Thermodynamic data for the Dissolution of Metallic Species in Aluminum ${ }^{(3)(36)(37)}$ (e.g., $\mathrm{Sr} \rightarrow \underline{\mathrm{Sr}}_{\mathrm{A})}$ )

\begin{tabular}{|l|c|}
\hline Metallic Species & $\Delta \mathrm{G}^{\circ}(\mathrm{kJ} /$ Mole $)$ \\
\hline Strontium & $-35.000+11.478 \mathrm{~T}$ \\
Magnesium & $-14.538-1.254 \mathrm{~T}$ \\
Bismuth & $22.213+6.376 \mathrm{~T}$ \\
Calcium & $-43.472+28.409 \mathrm{~T}$ \\
Silicon & $40.158+28.409 \mathrm{~T}$ \\
\hline
\end{tabular}

The thermodynamic calculations were performed using the following inputs to the EQUILIB routine.

$$
\begin{aligned}
& \mathrm{SrCO}_{3}+100 \mathrm{Al}+<\mathrm{A}>\mathrm{Mg}= \\
& \mathrm{SrCO}_{3}+100 \mathrm{Al}+<A>\mathrm{Ca}= \\
& \mathrm{SrCO}_{3}+100 \mathrm{Al}+<\mathrm{A}>\mathrm{Na}= \\
& \mathrm{SrCO}_{3}+100 \mathrm{Al}+<\mathrm{A}>\mathrm{Bi}=
\end{aligned}
$$

The complete output obtained from $\mathrm{F}^{*} \mathrm{~A}{ }^{*} \mathrm{C} * \mathrm{~T}$ for the magnesium and bismuth additions is given in Appendix B. The EQUILIB program outputs the most stable products resulting from the reaction. The reaction products for each input are shown in Tables XXIV to XXVII. 
Table XXIV F*A*C*T Prediction of Reaction Products

Al-Mg Alloy at $1273 \mathrm{~K}$ and $1 \mathrm{~atm}$.

\begin{tabular}{|c|c|c|c|c|c|c|}
\hline , : & \multicolumn{6}{|c|}{ PRODUCTS (Mole) } \\
\hline$\langle A\rangle$ & Sr & $\mathrm{Mg}$ & $\mathrm{MgO}$ & $\mathrm{Al}_{2} \mathrm{O}_{3}$ & $\mathrm{SrO} \cdot \mathrm{Al}_{2} \mathrm{O}_{3}$ & $\mathrm{Al}_{4} \mathrm{C}_{3}$ \\
\hline 0 & 0.26 & 0.00 & 0.00 & 0.00 & 0.74 & 0.33 \\
\hline 2 & 0.32 & 1.74 & 0.25 & 0.01 & 0.68 & 0.33 \\
\hline 4 & 0.38 & 3.50 & 0.49 & 0.01 & 0.62 & 0.33 \\
\hline 6 & 0.44 & 5.27 & 0.73 & 0.01 & 0.56 & 0.33 \\
\hline 8 & 0.50 & 7.08 & 0.96 & 0.01 & 0.50 & 0.33 \\
\hline 10 & 0.55 & 8.81 & 1.19 & 0.01 & 0.45 & 0.33 \\
\hline 20 & 0.98 & 17.07 & 2.13 & 0.01 & 0.01 & 0.33 \\
\hline 30 & 1.00 & 27.00 & 2.31 & 0.01 & 0.00 & 0.33 \\
\hline
\end{tabular}

Table XXIV shows that the strontium extraction increased with increasing the $\mathrm{Mg}: \mathrm{Sr}$ molar ratio. On the other hand, the amount of $\mathrm{SrO} \cdot \mathrm{Al}_{2} \mathrm{O}_{3}$ decreased as the total amount of strontium extraction increased. At $10 \mathrm{Mg}: \mathrm{Sr}$ molar ratio, the strontium extraction was predicted to be greater than 55\%. By increasing the amount of magnesium, i.e., 30Mg:Sr molar ratio, $100 \%$ strontium extraction was predicted. The amounts of aluminum oxide, $\mathrm{Al}_{2} \mathrm{O}_{3}$, and aluminum carbide, $\mathrm{Al}_{4} \mathrm{C}_{3}$, present in the products were constant across the range of input to the simulation process. The amount of magnesium, as a product, increased proportionally with the quantity added as reactant. Similarly, the amount of magnesium oxide, $\mathrm{MgO}$, produced increased as more magnesium was added to the system. The amount of other products predicted remained constant over the entire range of the simulation. Table XXV shows the products obtained with calcium addition. It can be seen that all the calcium was predicted to form $\mathrm{CaAl}_{4}$ and $\mathrm{CaAl}_{2}$. The other products obtained from the thermodynamic simulation with $\mathrm{Ca}$ addition $\left(\mathrm{Al}_{2} \mathrm{O}_{3}, \mathrm{SrO} \cdot \mathrm{Al}_{2} \mathrm{O}_{3}\right.$ and $\mathrm{Al}_{4} \mathrm{C}_{3}$ ) were essentially the same that those predicted with $\mathrm{Mg}, \mathrm{Na}$ and $\mathrm{Bi}$ additions. 
Table XXV $\mathrm{F}^{*} \mathrm{~A} * \mathrm{C}^{*} \mathrm{~T}$ Prediction of Reaction Products $\mathrm{Al}-\mathrm{Ca}$ Alloy at $1273 \mathrm{~K}$ and $1 \mathrm{~atm}$.

\begin{tabular}{|c|c|r|r|c|c|c|}
\hline & \multicolumn{7}{|c|}{ PRODUCTS (Mole) } \\
\hline$<\mathrm{Ar}>$ & \multicolumn{1}{|c|}{$\mathrm{Sr}$} & \multicolumn{1}{c|}{$\mathrm{CaAl}_{4}$} & \multicolumn{1}{c|}{$\mathrm{CaAl}_{2}$} & $\mathrm{Al}_{2} \mathrm{O}_{3}$ & $\mathrm{SrO}^{\prime} \mathrm{Al}_{2} \mathrm{O}_{3}$ & $\mathrm{Al}_{4} \mathrm{C}_{3}$ \\
\hline 0 & 0.26 & 0.00 & 0.00 & 0.01 & 0.74 & 0.33 \\
2 & 0.26 & 1.38 & 0.61 & 0.01 & 0.74 & 0.33 \\
4 & 0.26 & 2.72 & 1.27 & 0.01 & 0.74 & 0.33 \\
6 & 0.26 & 4.01 & 1.99 & 0.01 & 0.74 & 0.33 \\
8 & 0.26 & 5.23 & 2.76 & 0.01 & 0.74 & 0.33 \\
10 & 0.26 & 6.37 & 3.63 & 0.01 & 0.74 & 0.33 \\
20 & 0.25 & 9.95 & 10.04 & 0.00 & 0.74 & 0.33 \\
30 & 0.25 & 8.34 & 21.66 & 0.00 & 0.74 & 0.33 \\
\hline
\end{tabular}

Table XXVI and XXVII are concerned with sodium and bismuth additions, respectively.

Table XXVI $\mathrm{F}^{*} \mathrm{~A}^{*} \mathrm{C}^{*} \mathrm{~T}$ Prediction of Reaction Products Al-Na Alloy at $1273 \mathrm{~K}$ and $1 \mathrm{~atm}$.

\begin{tabular}{|c|c|c|c|c|c||}
\hline \hline & \multicolumn{5}{|c|}{ PRODUCTS (Mole) } \\
\hline$<\mathrm{A}>$ & $\mathrm{Sr}$ & $\mathrm{Na}$ & $\mathrm{Al}_{2} \mathrm{O}_{3}$ & $\mathrm{SrO}^{2} \mathrm{Al}_{2} \mathrm{O}_{3}$ & $\mathrm{Al}_{4} \mathrm{C}_{3}$ \\
\hline 0 & 0.26 & 0.0 & 0.01 & 0.74 & 0.33 \\
2 & 0.26 & 2.0 & 0.01 & 0.74 & 0.33 \\
4 & 0.26 & 4.0 & 0.01 & $0.7 c_{4}$ & 0.33 \\
6 & 0.26 & 6.0 & 0.01 & 0.74 & 0.33 \\
8 & 0.26 & 8.0 & 0.01 & 0.74 & 0.33 \\
10 & 0.26 & 10.0 & 0.01 & 0.74 & 0.33 \\
20 & 0.26 & 20.0 & 0.02 & 0.74 & 0.33 \\
30 & 0.26 & 30.0 & 0.02 & 0.74 & 0.33 \\
\hline
\end{tabular}


Table XXVII F*A*C*T Prediction of Reaction Products

Al-Na Alloy at $1273 \mathrm{~K}$ and $1 \mathrm{~atm}$.

\begin{tabular}{|r|c|c|c|c|c|c||}
\hline $\begin{array}{r}\text { Equiv. } \\
\text { (Wt\%) }\end{array}$ & $<\mathrm{A}>$ & $\mathrm{Sr}$ & $\mathrm{Bi}$ & $\mathrm{Al}_{2} \mathrm{O}_{3}$ & $\mathrm{SrO}^{2} \cdot \mathrm{Al}_{2} \mathrm{O}_{3}$ & $\mathrm{Al}_{4} \mathrm{C}_{3}$ \\
\hline 0.00 & 0.00 & 0.26 & 0.00 & 0.01 & 0.74 & 0.33 \\
1.13 & 0.05 & 0.26 & 0.05 & 0.01 & 0.74 & 0.33 \\
2.23 & 0.10 & 0.26 & 0.10 & 0.01 & 0.74 & 0.33 \\
4.37 & 0.20 & 0.26 & 0.20 & 0.01 & 0.74 & 0.33 \\
3.37 & 0.40 & 0.26 & 0.40 & 0.01 & 0.74 & 0.33 \\
15.45 & 0.80 & 0.26 & 0.80 & 0.01 & 0.74 & 0.33 \\
18.60 & 1.00 & 0.26 & 1.00 & 0.01 & 0.74 & 0.33 \\
\hline
\end{tabular}

The addition of sodium and bismuth did not improve the strontium extraction. Moreover, the addition did not lead to the formation of $\mathrm{Na}$ or $\mathrm{Bi}$ compounds. The amount of $\mathrm{Na}$ and $\mathrm{Bi}$ added as reactant was equal to the amount of free sodium and bismuth predicted as products. The other products and the amounts were the same for both the $\mathrm{Na}$ and $\mathrm{Bi}$ additions. 


\section{EXPERIMENTAL}

\section{V.1 OBJECTIVE}

The experimental program consisted of two parts and involved a total of eight experiments. The first part, Experiments 0 to 5, was concerned with the effect of changing the $\mathrm{Mg}: \mathrm{Sr}$ molar ratio on the recovery of strontium into the molten phase. Magnesium was added to the melt to lower the surface tension of aluminum and to increase the oxygen affinity of the melt. The second part, Experiments 6 to 8 , investigated the effect of lowering the surface tension, without altering the oxygen affinity, on strontium recovery. In the second set of experiments, bismuth was added to the melt to lower the surface tension. The results for strontium recovery with magnesium addition or bismuth addition are discussed. The experimental procedure consisted in essence of melting the aluminum reductant in a crucible and adding the source material, $\mathrm{SrCO}_{3}$. The reartants were mixed together by an impeller and were held under an argon atmosphere to minimize oxidation. Samples were taken every twenty minutes for kinetic analysis. The experiments were carried out under the same conditions of temperature, pressure, stirring intensity, reactant masses, argon atmosphere and time. 


\section{V.2 APPARATUS}

\section{V.2.1 Induction Furnace}

Experiments were carried out in a $30 \mathrm{~kW}$, Tocco induction furnace, Figure 12.

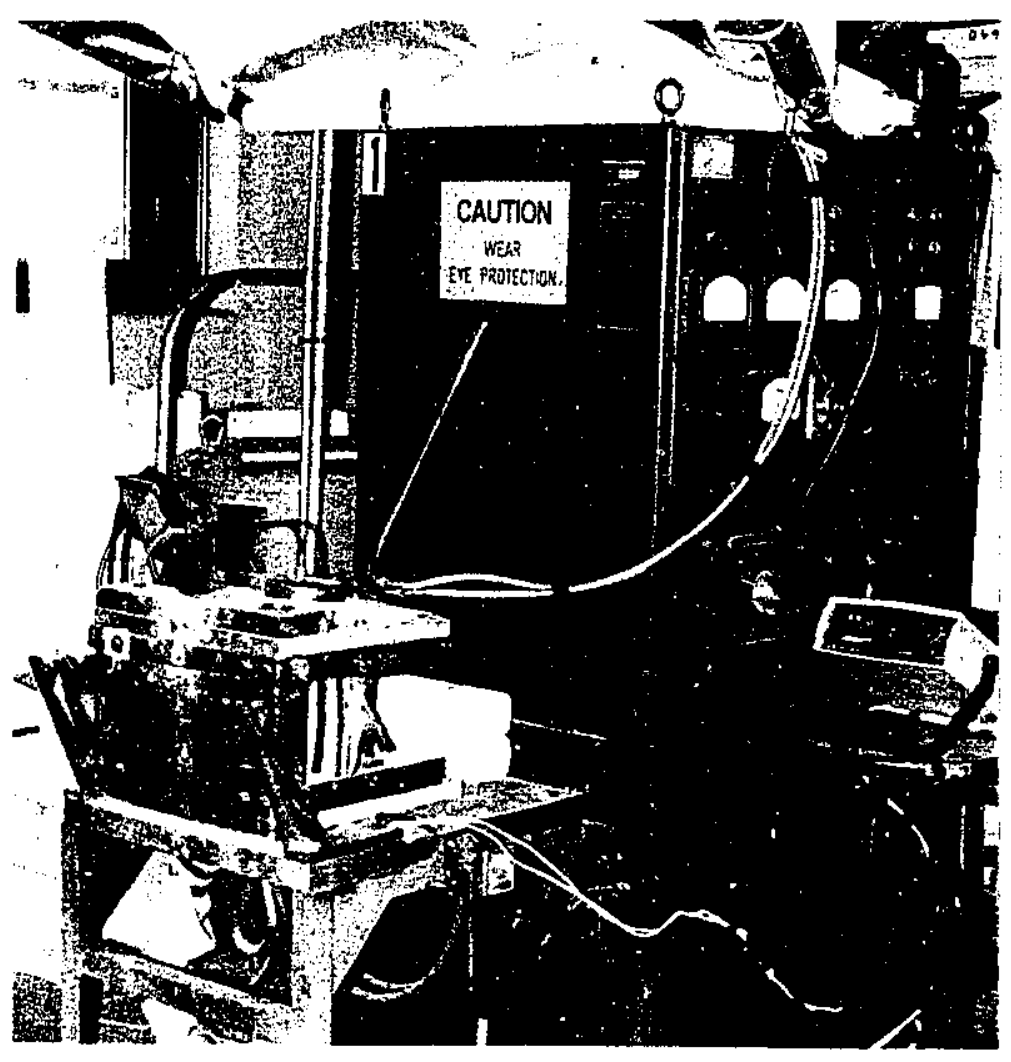

Figure 12. Tocco Induction Furnace and Generator

The coil diameter was approximately 10 inches. The furnace was equipped with flexible lends providing cooling water. These flexible connections permitted tilting capabilities for casting the melt. Power was supplied by a $30 \mathrm{~kW}, 440 \mathrm{~V}, 68 \mathrm{~A}$ generator.

\footnotetext{
"Manufactured by Inductotherm Inc., Rancocas, N.J.
} 


\section{V.2.2 Crucibles}

8

The crucibles used in all experiments were made of alumina ${ }^{b}$ and had the external dimensions of $20 \mathrm{crn}$ height with a diameter of $11.5 \mathrm{~cm}$. The internal dimensions were $18.5 \mathrm{~cm}$ height with a diameter of $9.4 \mathrm{~cm}$.

Molifications were performed on the crucibles in order to install two thermocouples in the bottom, Figure 13.

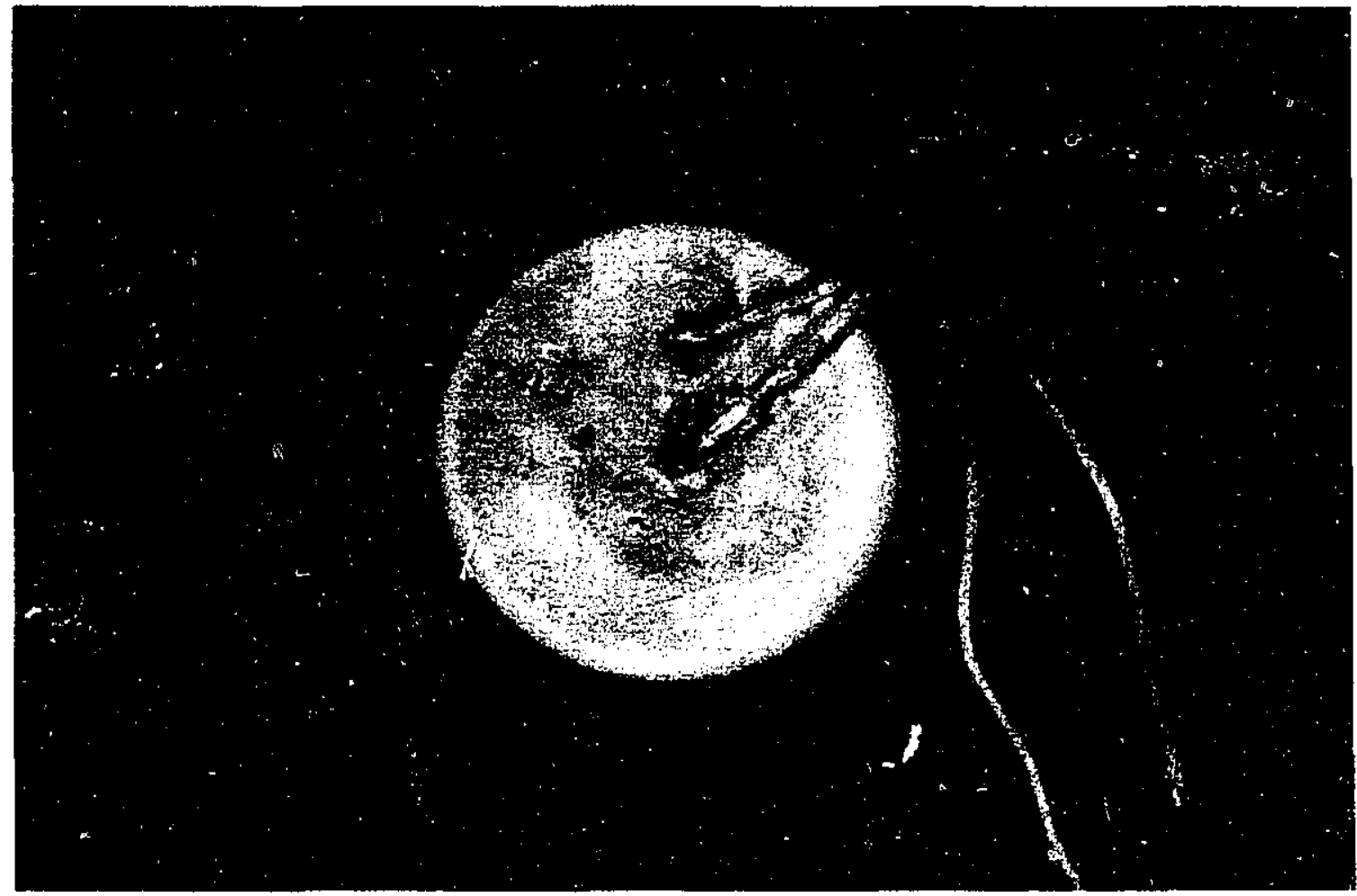

Figure 13. Bonded Alumina Crucible with Thermocouples in place

b LECO Instrument, Longeuil, Qc 


\section{V.2.3 Impeller}

The impellers were made of high temperature refractory cement ${ }^{c}$ bonded onto a steel mesh skeleton welded on a $1.9 \mathrm{~cm}$ steel shaft, Figures 14 and 15.

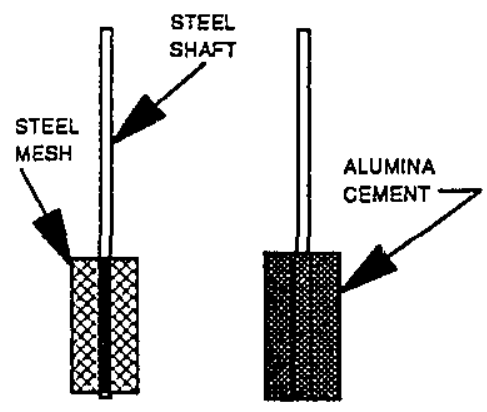

Figure 14. Schematic of the Impeller and the Skeleton

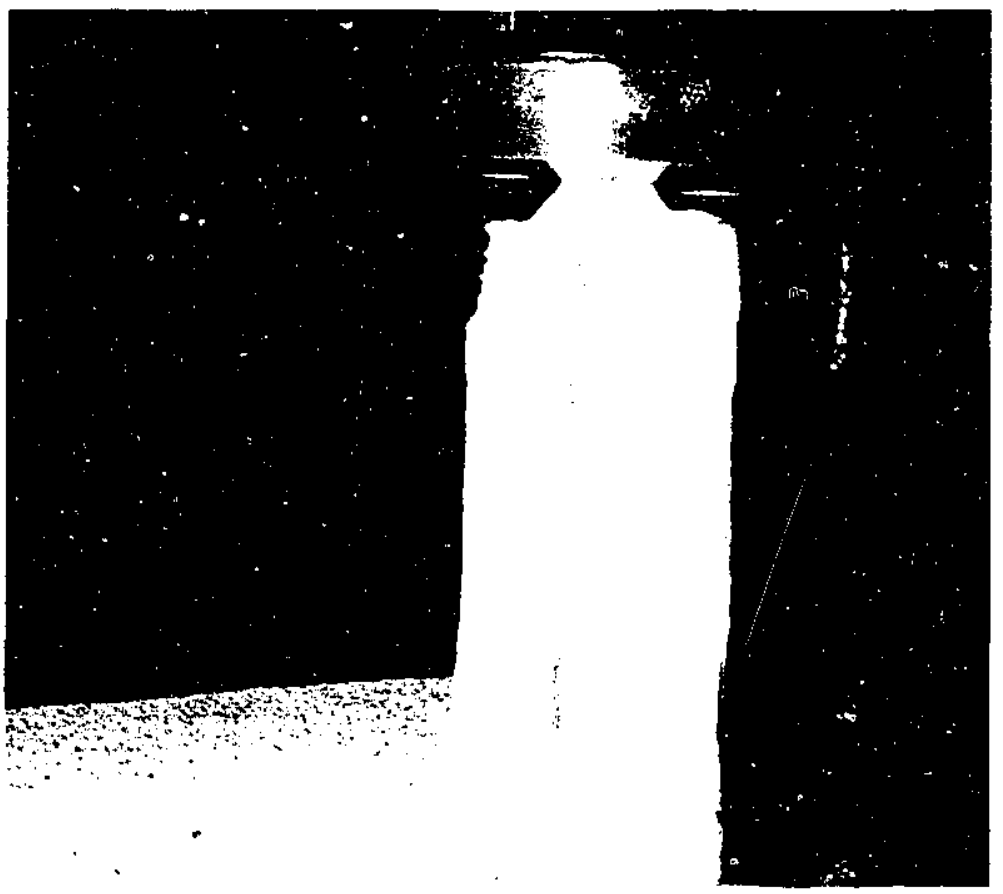

Figure 15 Alumina impeller

c Greencast 97, Supplied by: A.P. Green, Montreal, Qc 


\section{V.2.4 Impeller Drive and Support Carriage}

The impeller was driven by chain which was coupled to a gearbox with a 7.5 to 1 ratio driven by a $0.25 \mathrm{HP}, 115 \mathrm{~V}$ electric motor. The maximum impeller speed provided by the assembly was 150 RPM. These components were assembled on a bogey in a way to permit raising, and lowering of the shaft support to which the impeller was attached, Figure 16.
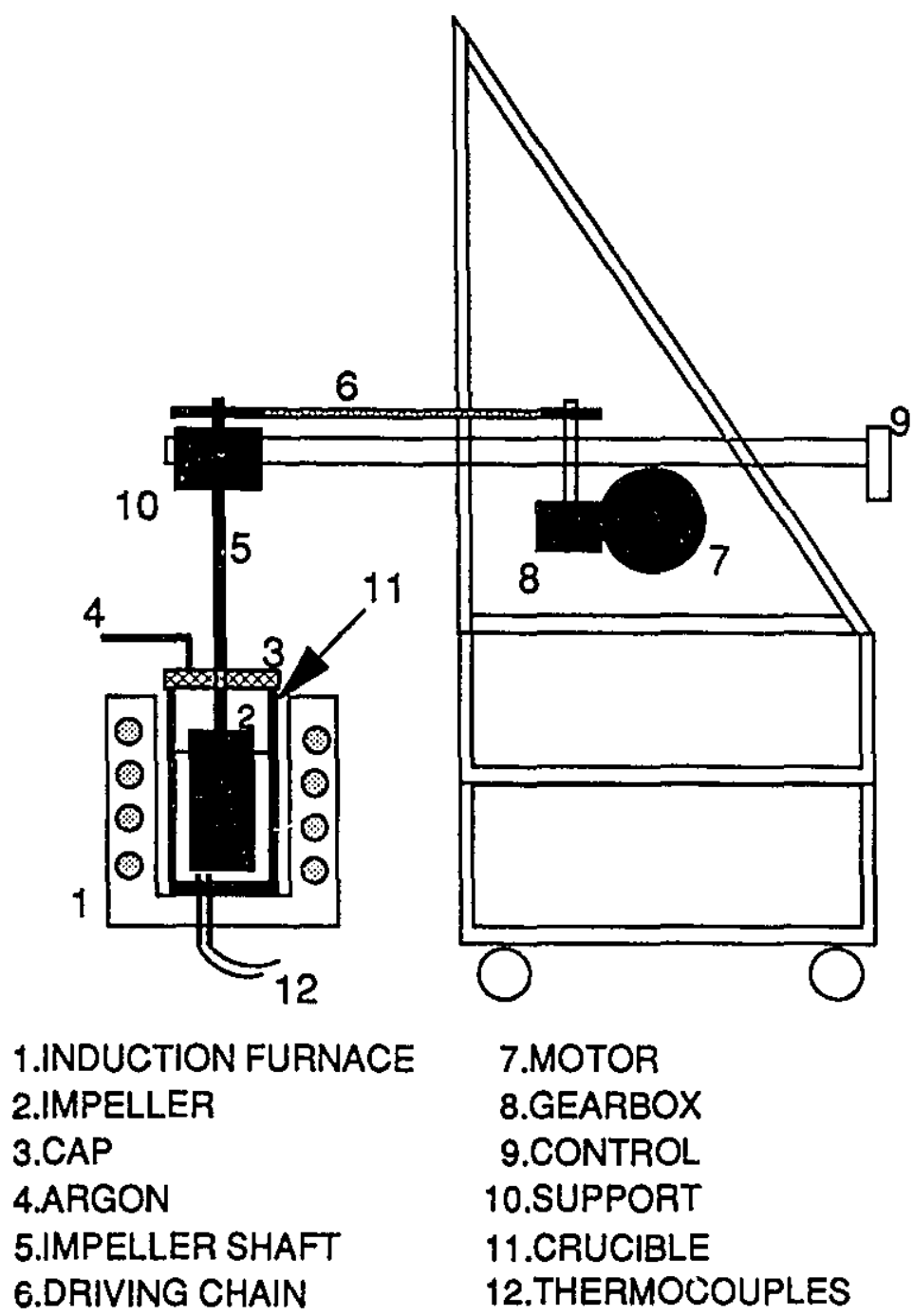

Figure 16. Schematic Representation of the Apparatus 


\section{V.2.5 Thermocouples}

Two thermocouples (one operational and one backup) were installed at the bottom of the crucible to provide continuous temperature measurement. Temperature measurements were checked with a handheld Omega type $\mathrm{K}$ thermocouple. Figure 13 showed the thermocouple setup in the crucible. It was possible to maintain the temperature relatively constant around the target temperature, the Figure 17, by manual adjustment of the power input on the basis of the temperature readings.

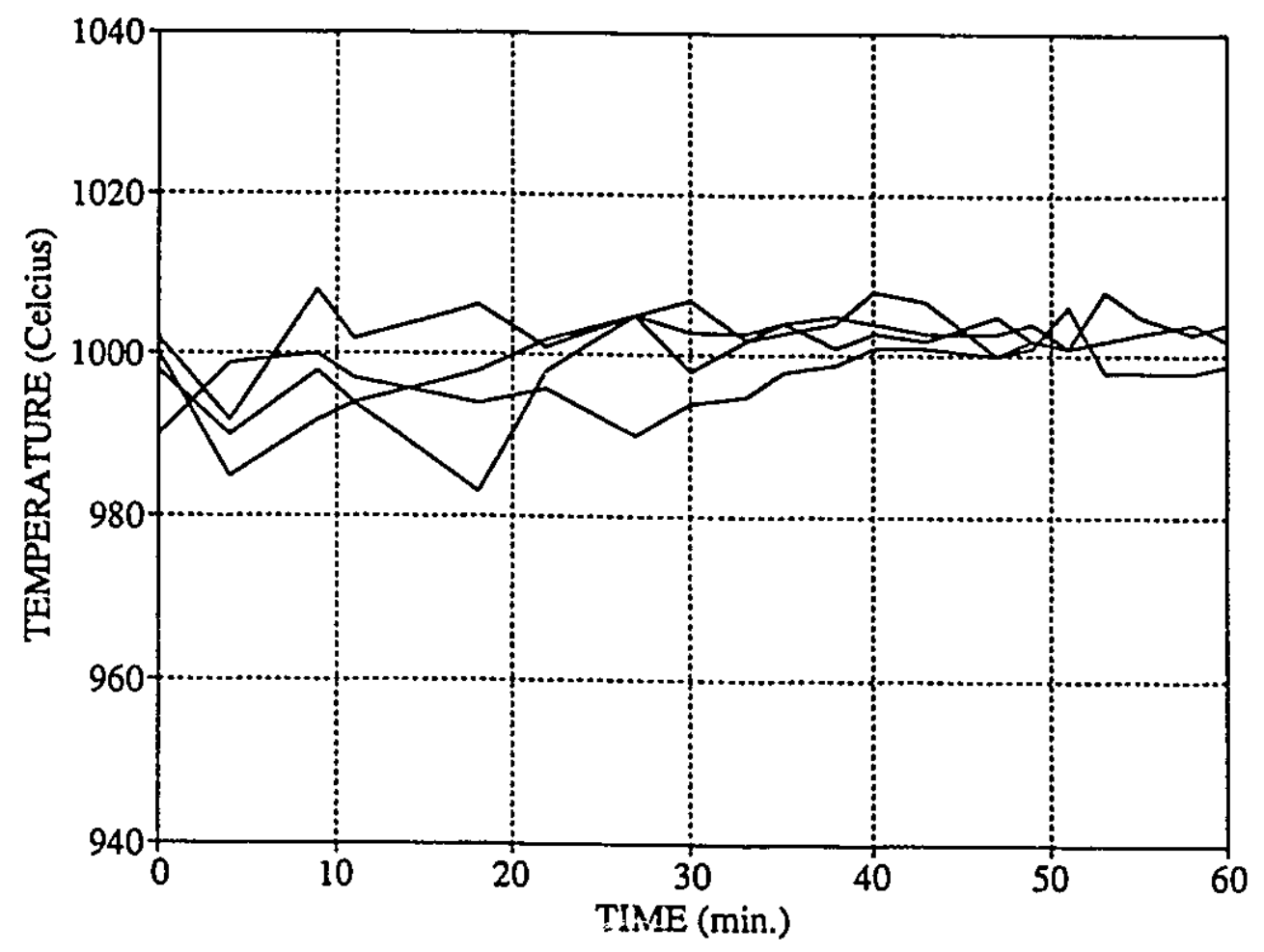

Figure 17 Temperature Variance with Time 


\section{V.2.6 Gas Purging}

A flow of argon ${ }^{d}$ over the melt was used in order to prevent oxidation of the melt surface. The argon gas was prepurified at $99.998 \%$ with less than $10 \mathrm{ppm}$ oxygen and water vapour. A Cole Parmer flowmeter, size \#3, with a $0.3175 \mathrm{~cm}$ diameter stainless steel ball was used to monitor and control the flow rate. The fraction of gas purged from the crucible every minute was calculated using the Equation 23 below $^{(38)}$.

$$
x=1-\exp \left[-\frac{Q}{V} t\right]
$$

where

$\mathrm{x}$ : Fraction of gas purged from the system

Q: Volume flow rate of the gas, $\left(\mathrm{cm}^{3} / \mathrm{s}\right)$

V: Volume to purge, $\left(\mathrm{cm}^{3}\right)$

t: Time of purging, (s)

The free volume (total volume of the crucible minus the volume of the impeller and the reactants) inside the crucible during the experiment was approximately $475 \mathrm{~cm}^{3}$ and the volume flow rate was $25 \mathrm{~cm}^{3} / \mathrm{s}$. Thus the fraction of gas purged every minute from the system was $95.8 \%$.

\footnotetext{
d Supplied by Welding Products Ltd., Montreal, Qc
} 


\section{V.2.7 Crucible Cap (Condenser)}

The crucible cap was made of brass. Three holes were drilled through the cap, one for the impeller shaft, one for the argon inlet and the last one for different utilities such as; viewport, temperature measurement, charging and sampling, Figure 18. The crucible cap acted as a condenser to condense volatile species which might escape. Cold water was circulated in a copper spiral tube soldered on top of the cap. The condenser offered a cold surface over the melt.

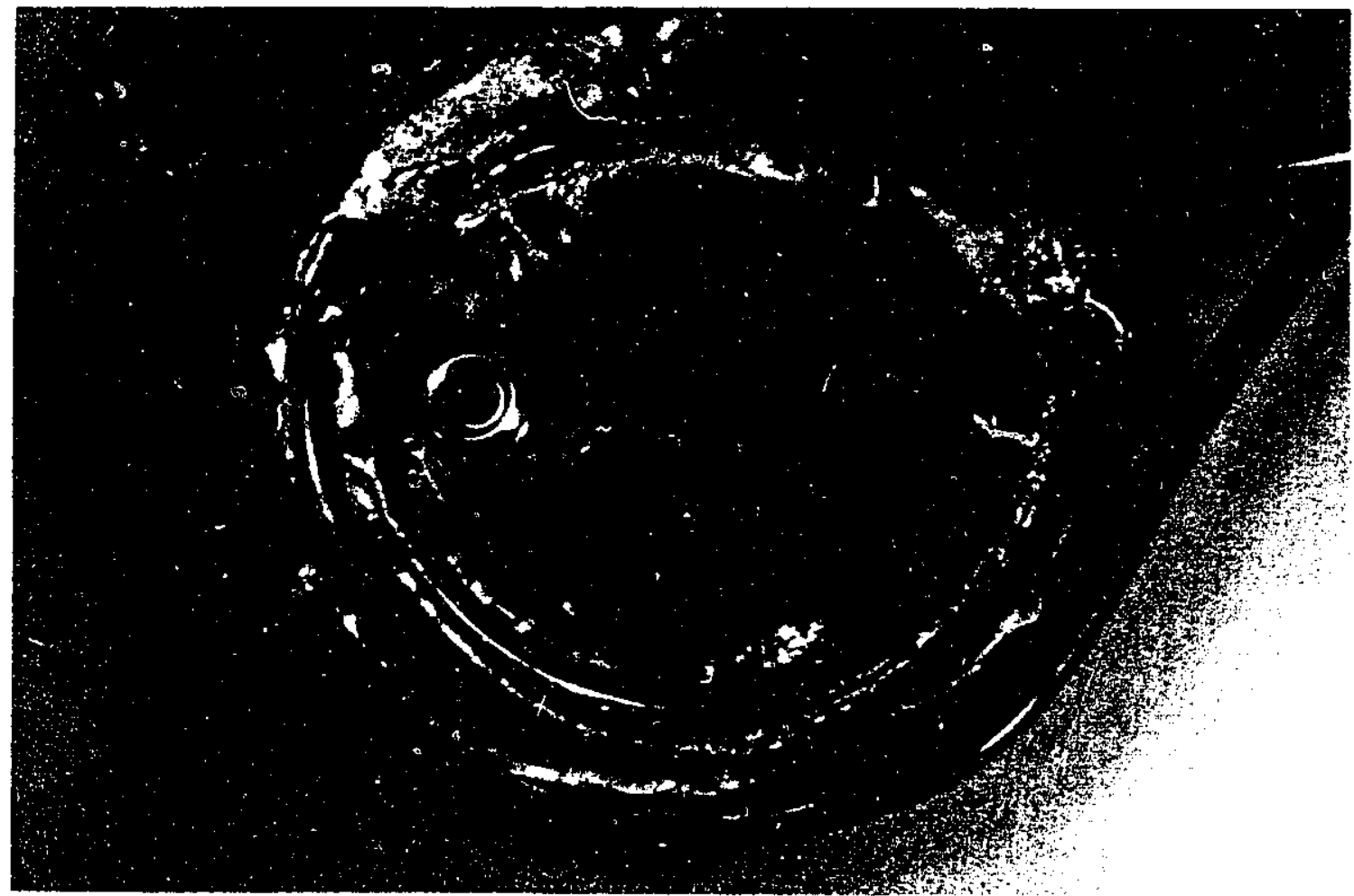

Figure 18 Condenser Cap for the Crucible 


\section{V.2.8 Sampling Method}

The sampling technique used during the experiments consisted of aspiration of the molten metal into a glass tube, Figure 19. The sample thus taken was immediately plunged in cold water to freeze the sample and to break the glass surrounding the frozen metal. The samples

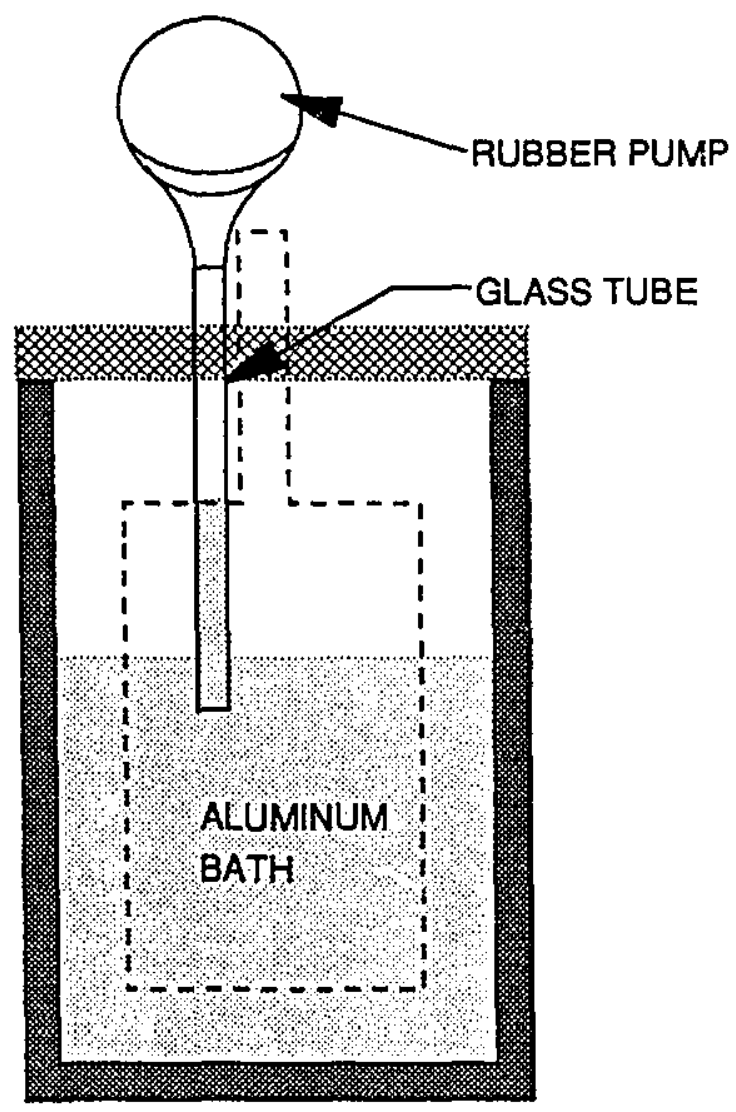

Figure 19 Schematic of the sampling method

extracted from the melt had an average mass of 20 grams. The size of the glass tubes used was $0.635 \mathrm{~cm} \mathrm{I.D} \mathrm{and} 40 \mathrm{~cm}$ long. The sampling was performed through the utility hole on the crucible cap. 


\section{V.3 MATERIALS}

The reactants used in the experiments were as follows:

Aluminume: Commercial grade at $99.97 \%$ purity

Magnesium': Commercial grade at $99.9 \%$ purity

Bismuth ${ }^{8}$ - Pure granules of bismuth with nominal composition of $99.9 \%$

$\mathrm{SrCO}_{3}{ }^{\mathrm{b}}: \quad$ Pure precipitated $\mathrm{SrCO}_{3}$, Grade AnalaR

- Supplied by ALCOA, Pittsburg, U.S.A.

I Supplied by Timminco, Haley, Ontario

- Supplied by American Chemicals Ltd.

a Supplied by BDH Chemicals Inc., Montreal, Qc 


\section{V.4 EXPERIMENTAL PREPARATION}

\section{V.4.1 Experimental Parameters}

The following parameters were controlled in order to maintain the consistent conditions for all experiments.
a) Melt temperature:
$1273 \mathrm{~K}$
b) Amount of aluminum (reductant):
$914.6 \mathrm{~g}$
c) Mixing rate:
$150 \mathrm{rpm}$
d) Argon volume flow rate:
$25 \mathrm{~cm}^{3} / \mathrm{s}$
e) Reaction time:
1 hour

Parameters which were changed from one experiment to another were the amount of magnesium and bismuth added. The amount of magnesium added was increased gradually and was reported as the molar ratio of magnesium to strontium. The amount of bismuth added was determined by calculation to lower the surface tension to the same extent as the magnesium additions. Additionally, one experiment was performed with a larger amount of bismuth to lower the surface tension much below the value reached with magnesium. 


\section{V.5 EXPERIMENTAL PROCEDURES FOR REDUCTION EXPERIMENTS}

\section{V.5.1 Preparation of Experiments}

The following procedures were followed during the preparation of an experiment:

1) The alumina crucible was placed in the furnace and surrounded with coarse silica sand which provided packing and insulation. Alumina cement was then used to cover the silica sand and secure the crucible for tilting and casting of the melt.

2) The internal surface of the condenser was cleaned to offer a good condensing surface and avoid contamination.

3) The impeller fabrication was delicate. The drying and firing procedures had to be performed precisely as recommended by the supplier. Bad procedure resulted in impeller failure socn after the immersion in the melt. Furthermore, the firing procedure eliminated the risk of explosion due to moisture trapped in the cement. Figure 20 below shows the program followed for this particular alumina cement.

The letter " $\mathrm{A}$ " designates the drying period of 24 hours at room temperature. The heating rate is represented by the letters $B, D$ and $F$ was $40^{\circ} \mathrm{C} / \mathrm{hr}$. The temperature was maintained for half an hour between each step (C: $120^{\circ} \mathrm{C}, \mathrm{E}: 260^{\circ} \mathrm{C}$ and G: $540^{\circ} \mathrm{C}$ ). After the final step, the power was turned off to permit slow cooling $(\mathrm{H})$. 


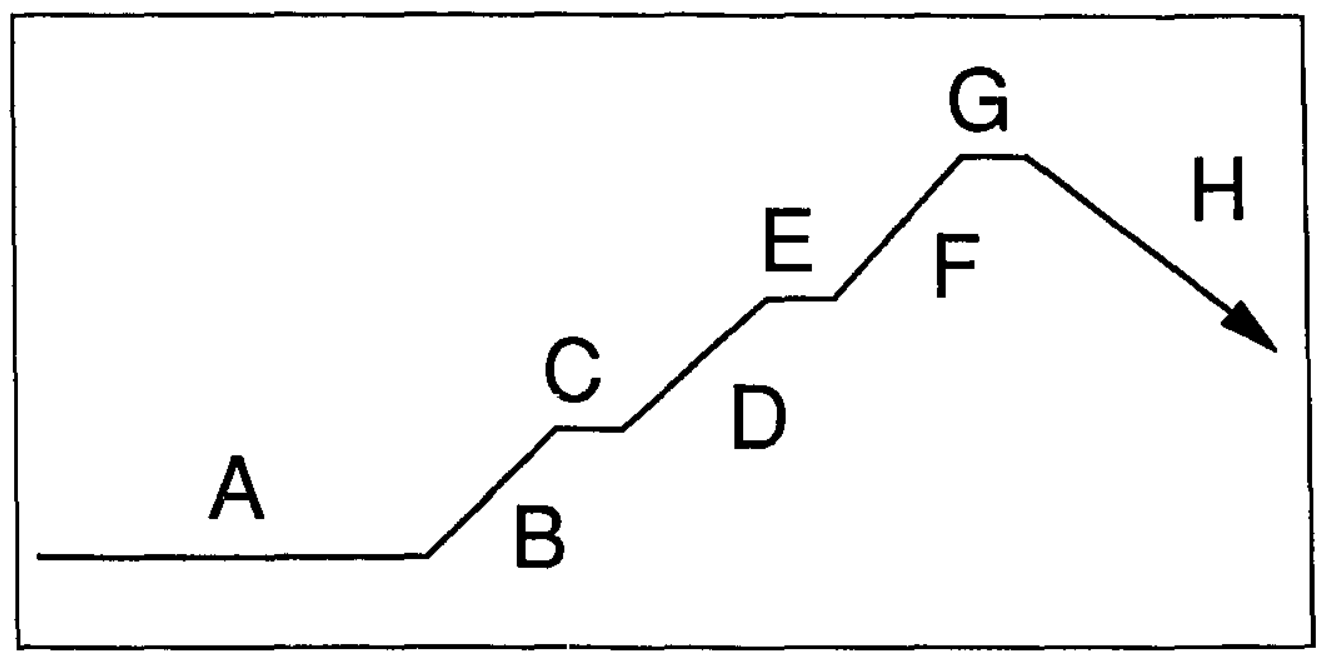

Figure 20 Drying and firing program of alumina cement 


\section{V.5.2 Experimental Procedures}

Charging for the first set of experiments consisted of loading the crucible with the aluminum cut in small pieces for faster melting. The furnace power was set to $30 \mathrm{~kW}$ and the material was completely melted after approximately 30 minutes. The time to reach the target temperature of $1000^{\circ} \mathrm{C}$ took another 30 minutes. Once the target temperature was reached, small pieces of magnesium were added and the impeller with the crucible cap were put in place and the stirring started. During melting, argon was continuously flushed inside the reactor to minimize oxidation. The immersion of the cold impeller slightly lowered the melt temperature. Once the temperature reached $1000^{\circ} \mathrm{C}$ again, the furnace was set at about $19 \mathrm{~kW}$, the strontium carbonate was added via the utility hole. At this point, the reduction experiment began for one hour. To keep the tsmperature stable, measurements were taken every two to three minutes and checked with a handheld thermocouple each 10 minutes. The furnace power was periodically adjusted in order to keep the target temperature. For the kinetic studies, samples were taken at twenty minute intervals via the utility hole. Sixty minutes after the strontium carbonate addition, stirring was stopped, the power shut off and the crucible cap, the impeller and the bogey removed. The crucible cap was reinstalled and argon gas kept flowing untii the temperature liached $750^{\circ} \mathrm{C}$. At the end of stirring, the upper part of the crucible was found to be covered by a powdered reaction product and other viscous materials which were scrapped out and placed in a container. The melt was then poured into a steel mold. After cooling of the crucible, thin metal films which had clung on the crucible wall and on the impeller and solidified were removed and added to the products. Before running another experiment, the impeller was 
repaired with alvwina cement.

\section{V.6 EXPERIMENTAL PROGRAM}

The experimental program consisted of two sets of experiments. The first set involved magnesium addition while the second set consisted of adding bismuth to the aluminum melt. These experiments are listed in Table XXVIII.

Table XXVMI Experimental Program

\begin{tabular}{|c|c|c|c|c|c|c|c|c||}
\hline & \multicolumn{3}{|c|}{ REACTANTS (g) } & \multicolumn{3}{c|}{ REACTANTS (mole) } & $\begin{array}{c}\text { Molar } \\
\text { Ratio }\end{array}$ & Add. \\
\hline Exp.\# & $\mathrm{Al}$ & $\mathrm{Mg}$ & $\mathrm{SrCO} 3$ & $\mathrm{Al}$ & $\mathrm{Mg}$ & $\mathrm{SrCO} 3$ & $\mathrm{Mg}: \mathrm{Sr}$ & $\mathrm{Wt} \%$ \\
\hline 0 & 914.6 & 0 & 50 & 33.9 & 0 & 0.34 & 0 & 0 \\
1 & 914.6 & 16.5 & 50 & 33.9 & 0.68 & 0.34 & 2 & 1.8 \\
2 & 914.6 & 32.9 & 50 & 33.9 & 1.35 & 0.34 & 4 & 3.5 \\
3 & 914.6 & 49.4 & 50 & 33.9 & 2.03 & 0.34 & 6 & 5.1 \\
4 & 914.6 & 66.0 & 50 & 33.9 & 2.72 & 0.34 & 8 & 6.7 \\
5 & 914.6 & 82.4 & 50 & 33.9 & 3.39 & 0.34 & 10 & 8.3 \\
\hline Exp.\# & $\mathrm{Al}$ & $\mathrm{Bi}$ & $\mathrm{SrCO}$ & $\mathrm{Al}$ & $\mathrm{Bi}$ & $\mathrm{SrCO} 3$ & $\mathrm{Bi}: \mathrm{Sr}$ & $\mathrm{Wt} \%$ \\
\hline 6 & 914.6 & 9.2 & 50 & 33.9 & 0.04 & 0.34 & 0.12 & 1 \\
7 & 914.0 & 27.7 & 50 & 33.9 & 0.13 & 0.34 & 0.38 & 3 \\
8 & 914.6 & 55.4 & 50 & 33.9 & 0.26 & 0.34 & 0.76 & 6 \\
\hline
\end{tabular}




\section{RESULTS}

\section{VI.1 REACTION PRODUCTS}

The reduction products under the present experimental conditions, fall into four main product categories:

- Ingot

- Dross

- Powder Residue

- Condensate

The powder residue and the dross were separated by screening. All products larger than 10 mesh in size were included in the dross which aiso included the thin layer of metal scrapped from the crucible walls and the impeller. The size fraction less than 10 mesh was included in the powder residue. Figures 21 and 22 present the masses of the powder residue versus the size. 
FRACTION PASSING VS. SIZE

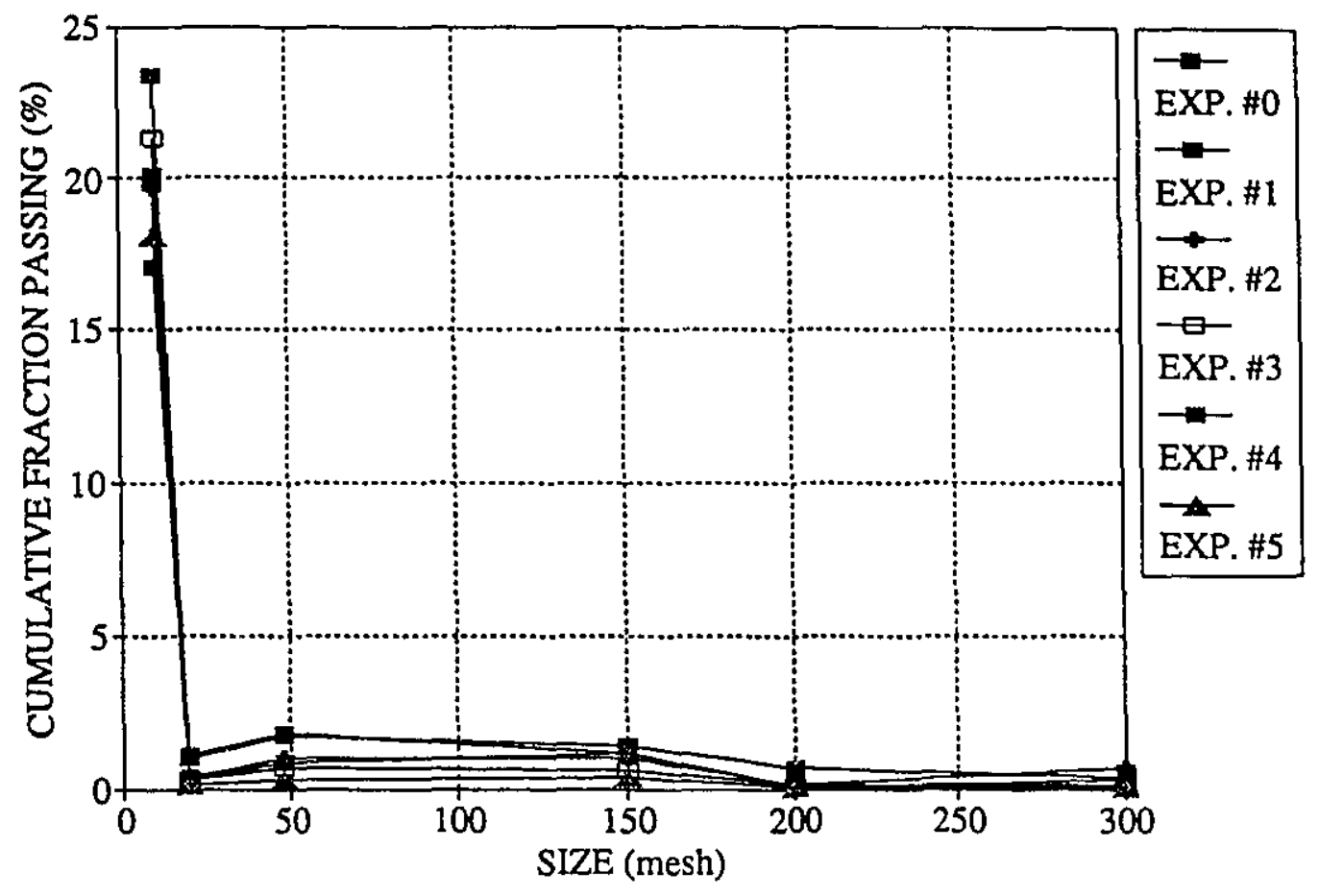

Figure 21 Size Fraction of the Powder Residue for Experiments 0 to 5 FRACTION PASSING VS. SIZE

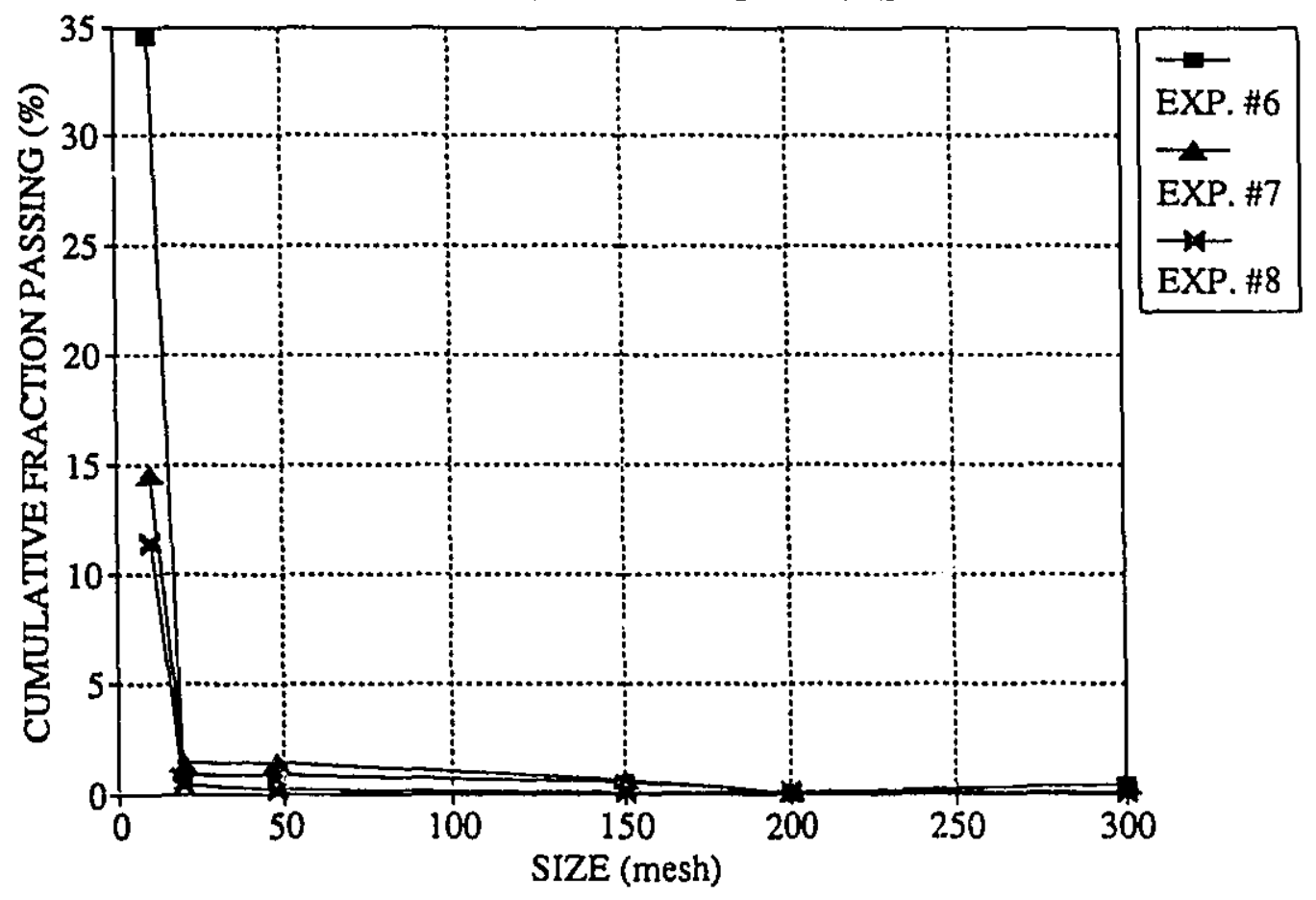

Figure 22 Size Fraction of the Powder Residue for Experiments 6 to 8 
Table XXIX shows the overall mass balance for each experiment. It also presents the difference (in percentage) between the original masses and the total of the product masses which is an indication of material losses. The experiment numbered " 0 " stands for the control experiment for which the melt contained no magnesium or bismuth addition.

Table XXIX Mass Balance for the Reaction Products

\begin{tabular}{|c|c|c|c|c|c|c|c|}
\hline \multirow[t]{2}{*}{ Exp.\# } & \multirow{2}{*}{$\begin{array}{c}\text { Mass of } \\
\text { Reactants (g) }\end{array}$} & \multicolumn{6}{|c|}{ Mass of Reaction Products (g) } \\
\hline & & Ingot ${ }^{*}$ & Dross & $\begin{array}{l}\text { Powder } \\
\text { Residue }\end{array}$ & Cond. & Total & $\begin{array}{l}\text { Diff. } \\
(\%)\end{array}$ \\
\hline 0 & 964.6 & 699.8 & 153.5 & 46.3 & - & 899.6 & -6.7 \\
\hline 1 & 981.1 & 722.6 & 191.8 & 41.2 & 0.5 & 956.1 & -2.6 \\
\hline 2 & 997.5 & 751.0 & 191.6 & 30.9 & 0.8 & 974.3 & -2.3 \\
\hline 3 & 1014.0 & 754.7 & 209.5 & 18.0 & 0.8 & 983.0 & -3.1 \\
\hline 4 & 1030.6 & 749.5 & 237.0 & 26.0 & 0.8 & 1013.3 & -1.7 \\
\hline 5 & 1046.0 & 823.3 & 184.4 & 9.1 & 0.8 & 1017.6 & -2.7 \\
\hline 6 & 973.8 & 578.0 & 316.6 & 23.7 & - & 918.3 & -5.7 \\
\hline 7 & 992.3 & 826.6 & 142.2 & 38.3 & 0.1 & 1007.2 & 1.5 \\
\hline 8 & 1019.0 & 942.9 & 115.0 & 7.2 & 0.1 & 1065.2 & 4.5 \\
\hline
\end{tabular}

The difference in percent was computed according to the mass of the reactants (Mass In) and the sum of the masses of the reaction products (Mass Out), Equation 24.

$$
\text { DIFF. (\%) }\left[\frac{\text { Mass of Products Mass of Reactants }}{\text { Mass of Reactants }}\right] \times 100
$$

Visual observations of tiic reaction products are presented in Figures 23 to 30 .

A condensate was found on the surface of the condenser facing the melt. For Experiments 1 to 5, the condensate was white and relatively thick (1 to $2 \mathrm{~mm}$ ). The condensate for Experiments 
6 to 8 was yellowish and a very small quantity was found, Figure 23 .

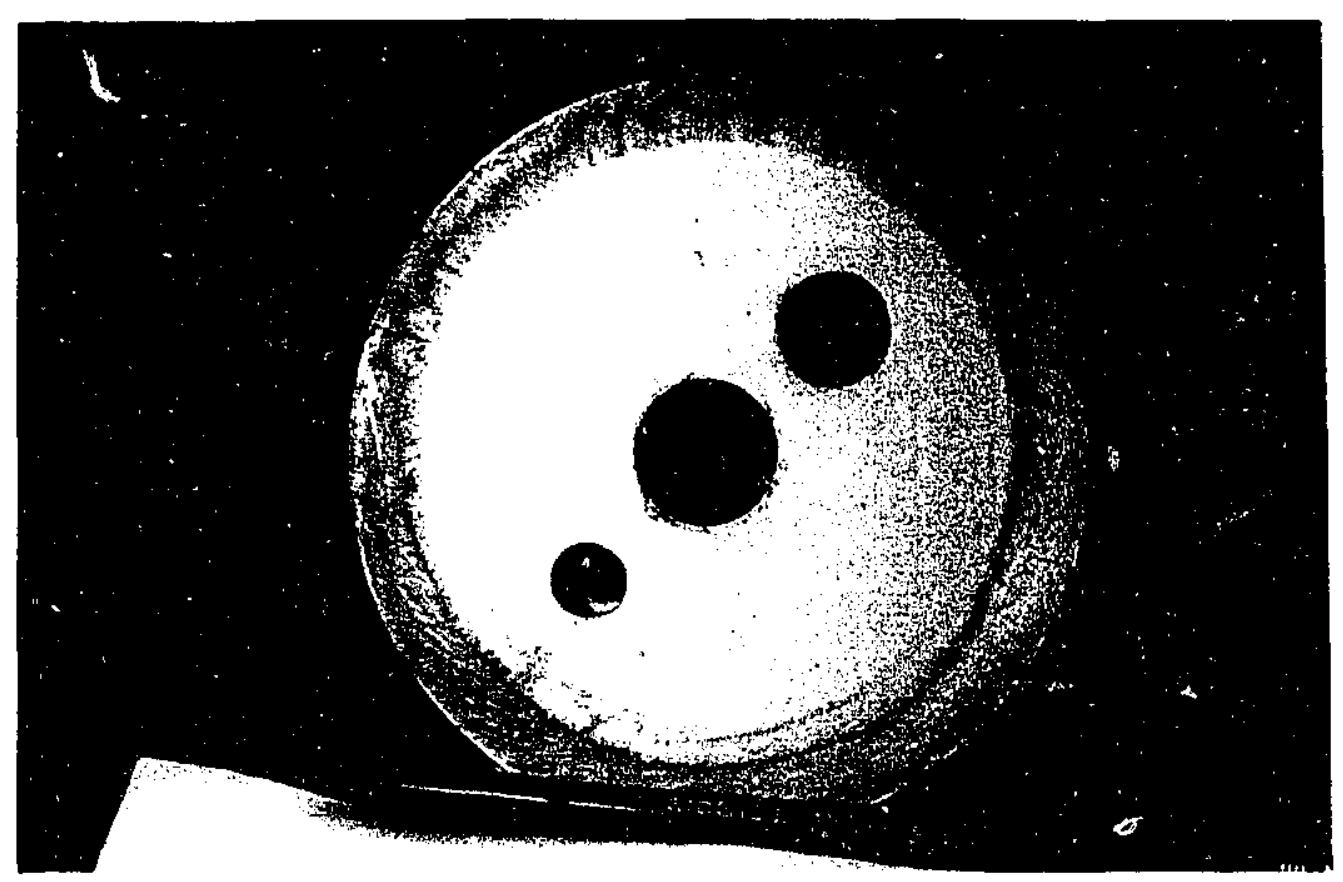

Figure 23 Condensate (Experiments 1 to 5)

Furthermore, during the experiments where magnesium was added, a white plume emerged from the crucible through the space around the impeller shaft, Figure 24. Obviously, this white plume did not condense and was part of material losses. It can be seen in Table XXIX that the masses of condensate recuperated in the magnesium addition experiments are similar. A similar observation can be made for the bismuth addition experiments.

The powder residue consisted of a mixture of aggregates and particles of vaiious sizes and shapes. This powder residue consisted of metallic droplets, porous metallic pieces, agglomerates, unreacted material, pieces of impellers and fine black powder, Figure 25. 


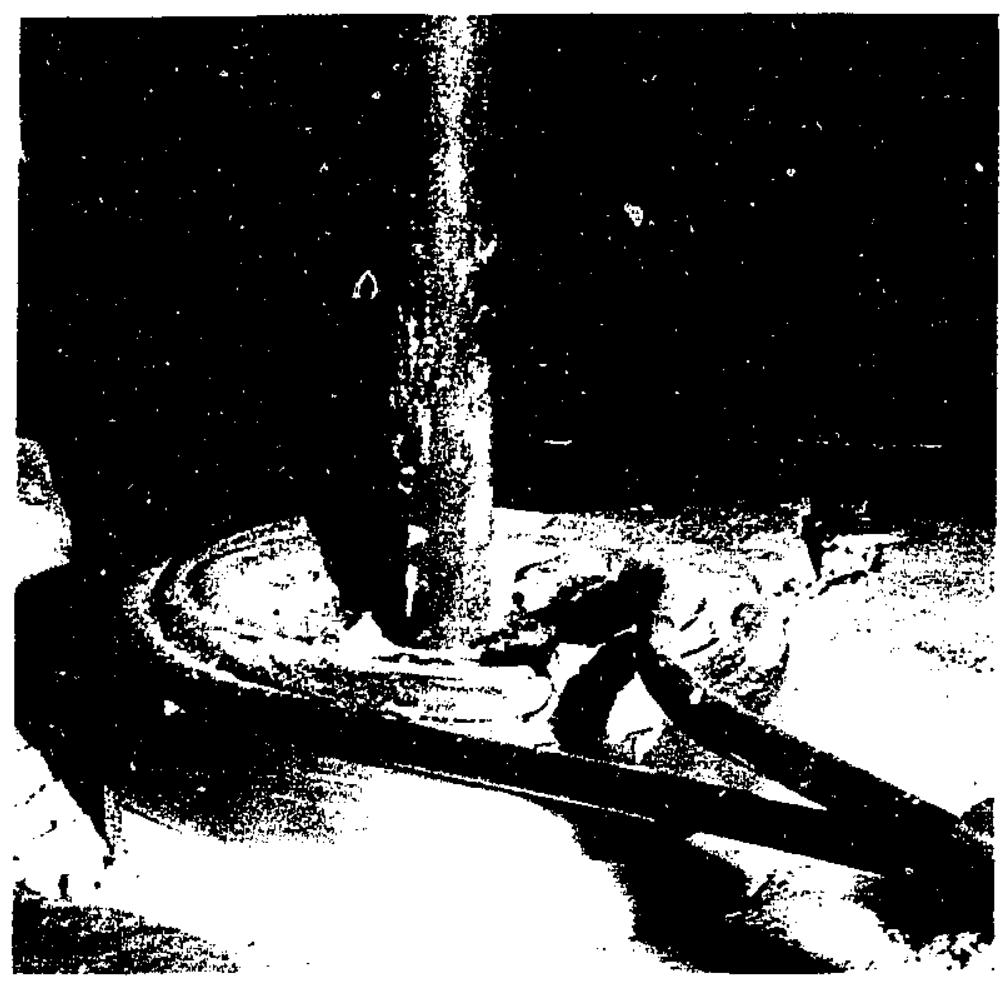

Figure 24 White plume escaping by the shaft hole

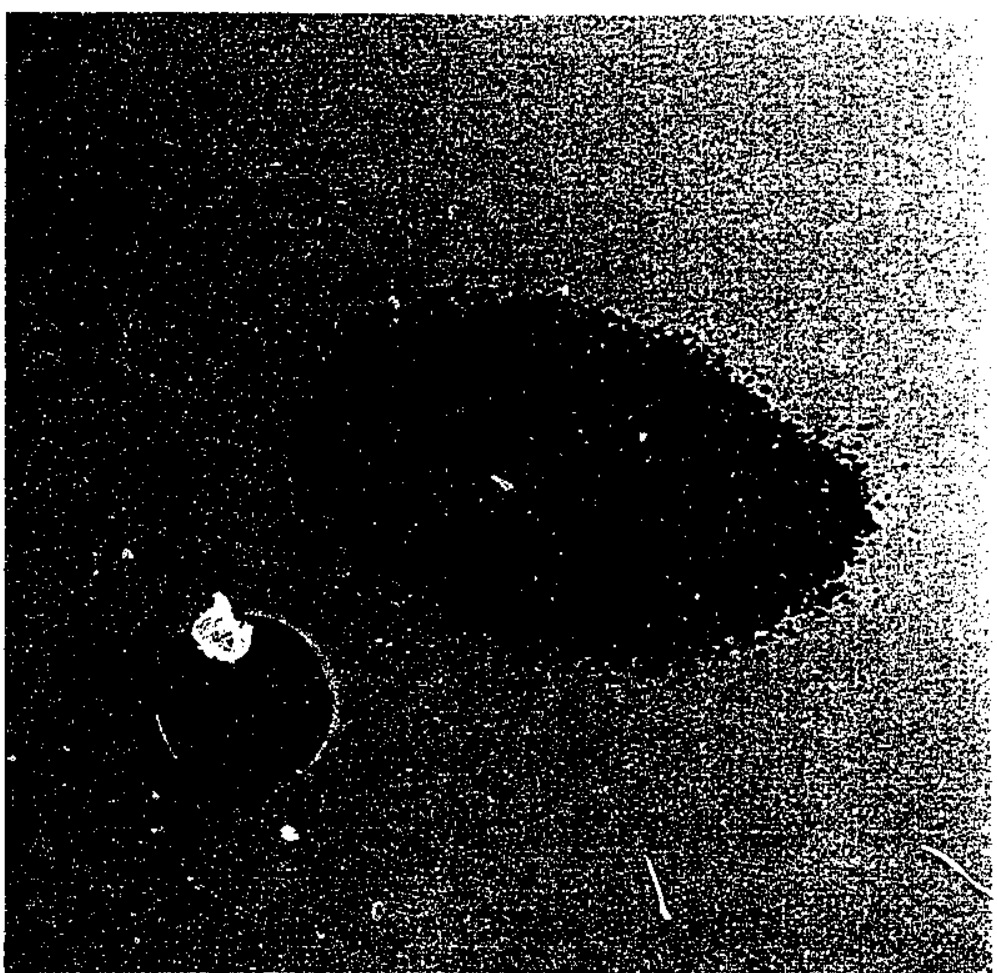

Figure 25 Powder residue 
The powder residue was found on the upper part of the crucible wall. The physical appearance of the powder residue obtained from the experiments was relatively sinilar. The amount of powder residue produced was almost the same for Experiments 0 to 8. Experiment 0 produced the most powder residue. This could be explained by the higher surface tension of the aluminum melt (no solute metal addition) which resulted in less solid wetted by the liquid. The dross consisted in irregular shapes of porous metal with material trapped in cavities and folds or embedded in the surface, Figure 26. Similar porous nature was observed for the dross obtained in each experiment.

Figure 26 Dross

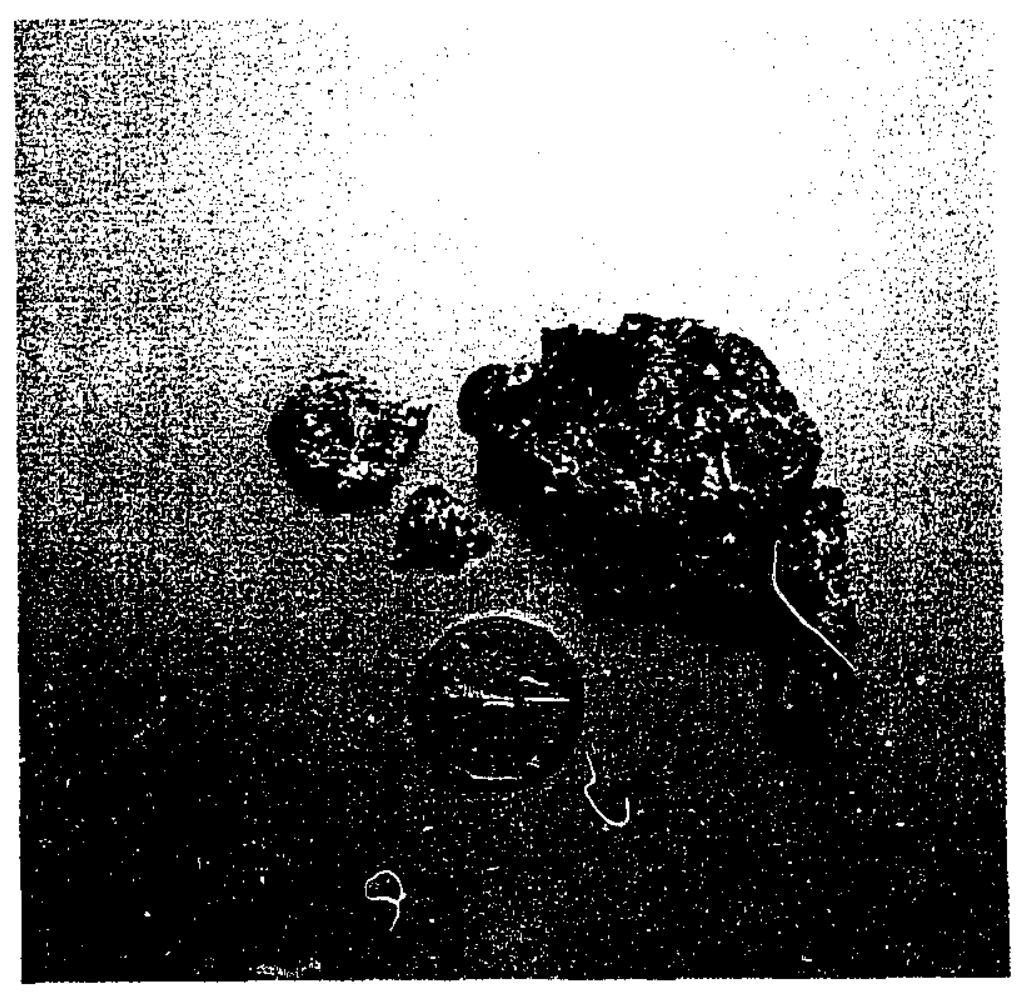

The dross was mainly recovered from the top of the melt prior to pour and from the crucible walls after pouring, Figure 27. The porous structure was possibly created by $\mathrm{CO}_{2}$ evolution from the carbonate dissociation, Equation 8. 


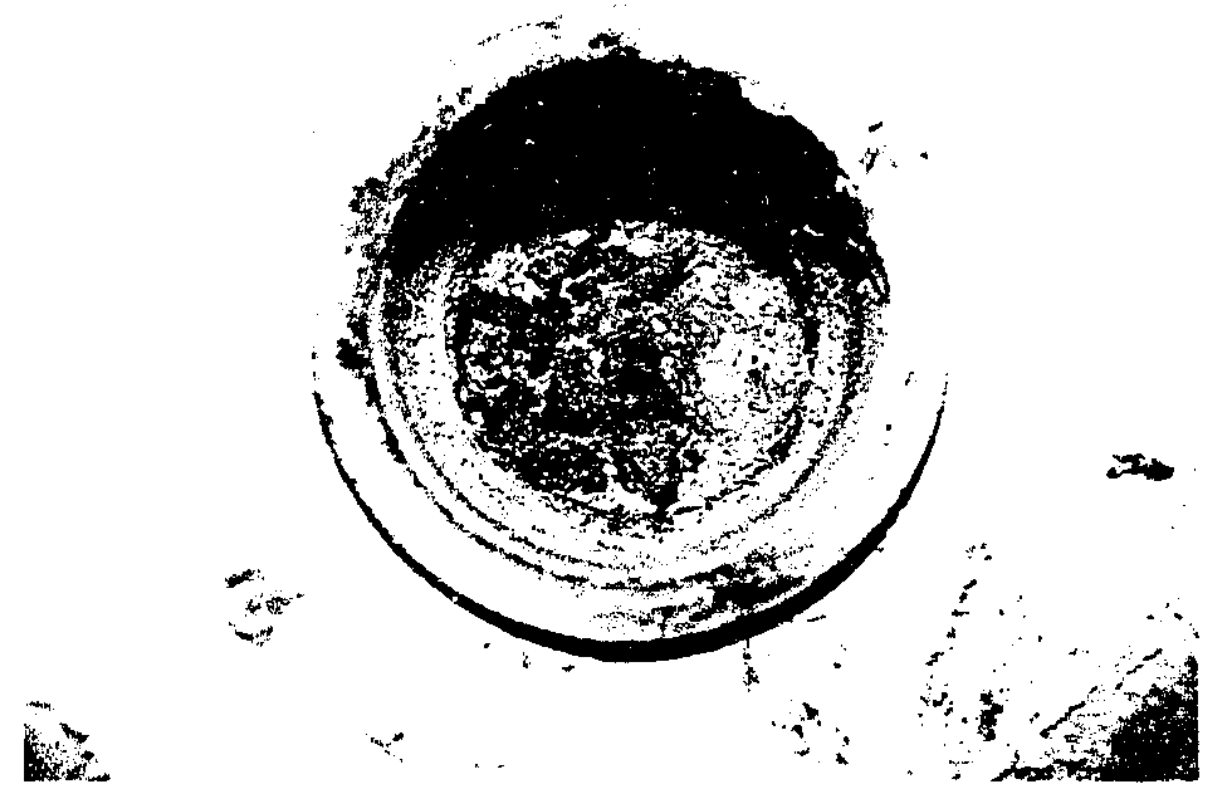

Figure 27 Dross on top of the melt and powder $\cdots \cdots$ crucible wall

The masses of powder residue produced were similar for the majority of the experiments. Similarly, the masses of dross produced were ralatively similar. At the end of each experiment, the molten bath was cast into a small ingot. The ingot masses were roughly the same for Experiments 0 to 5 and varied increasingly from Experiment 6 to 8, Figure 28.

During pouring, some material was trapped in the ingot or embedded in the surface. Depending on the metallic addition, $\mathrm{Mg}$ or $\mathrm{Bi}$, the ingot displayed different surface appearances, shiny or dull, respectively, Figure 29 and 30. 


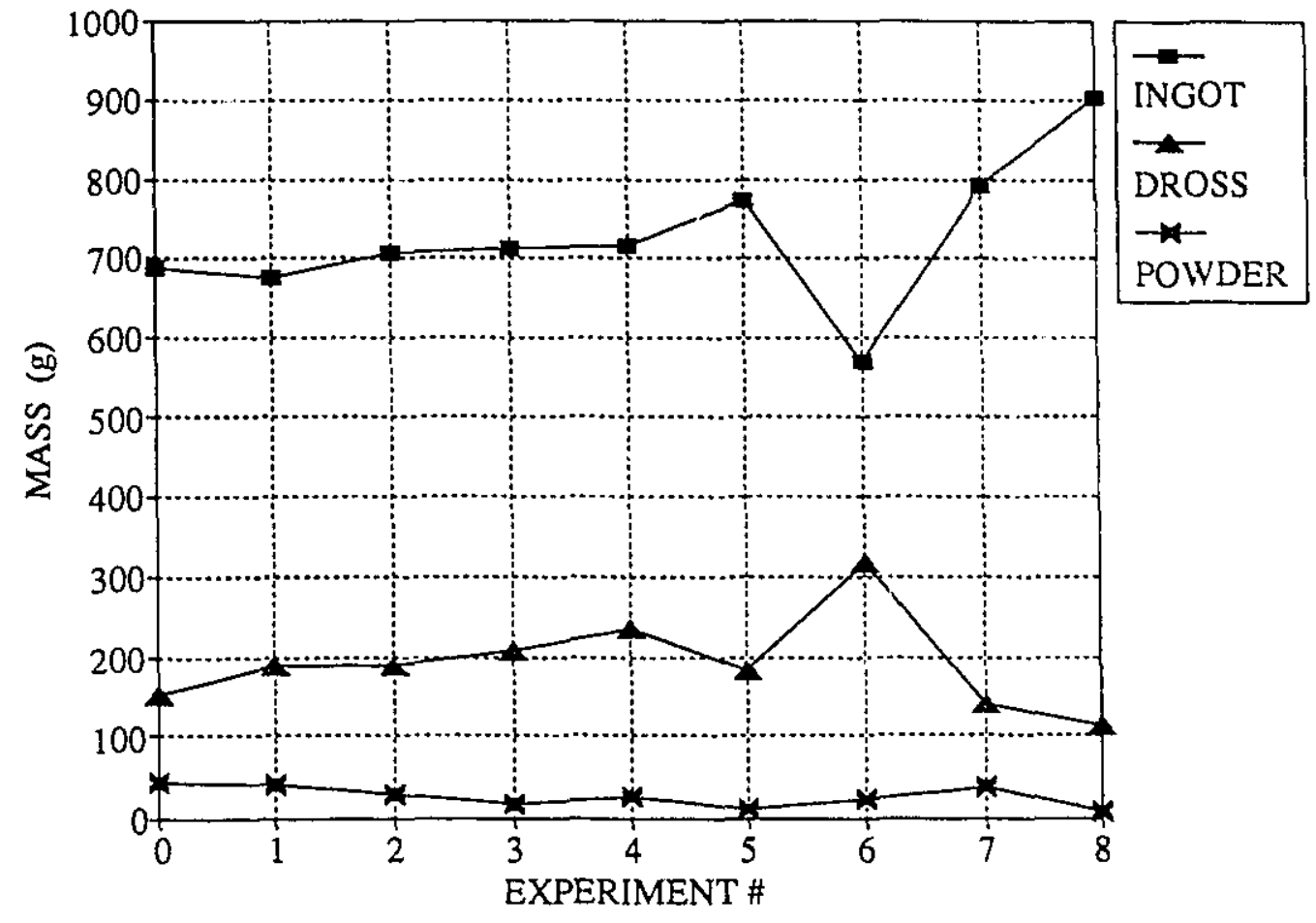

Figure 28 Mass of reaction products for each experiment

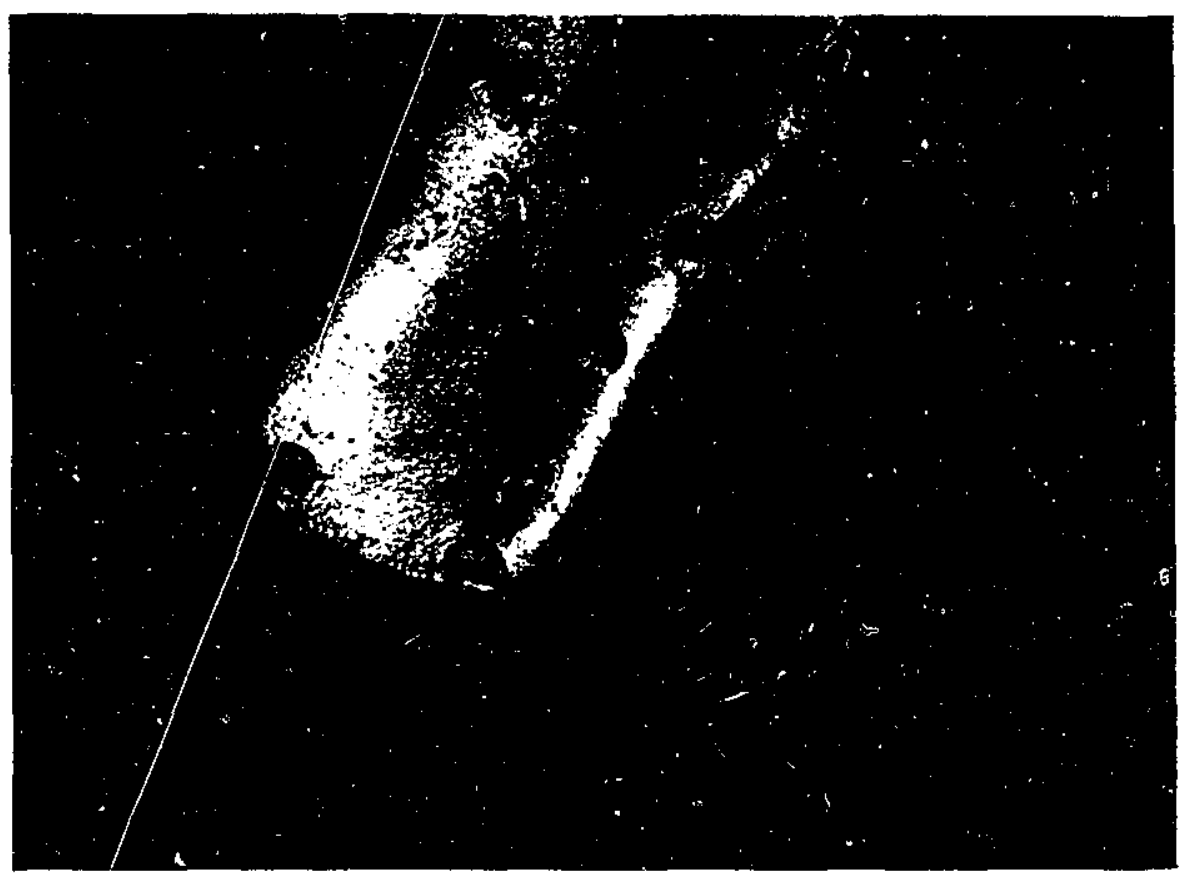

Figure 29 Metal ingot ( $\mathrm{Mg}$ addition) 


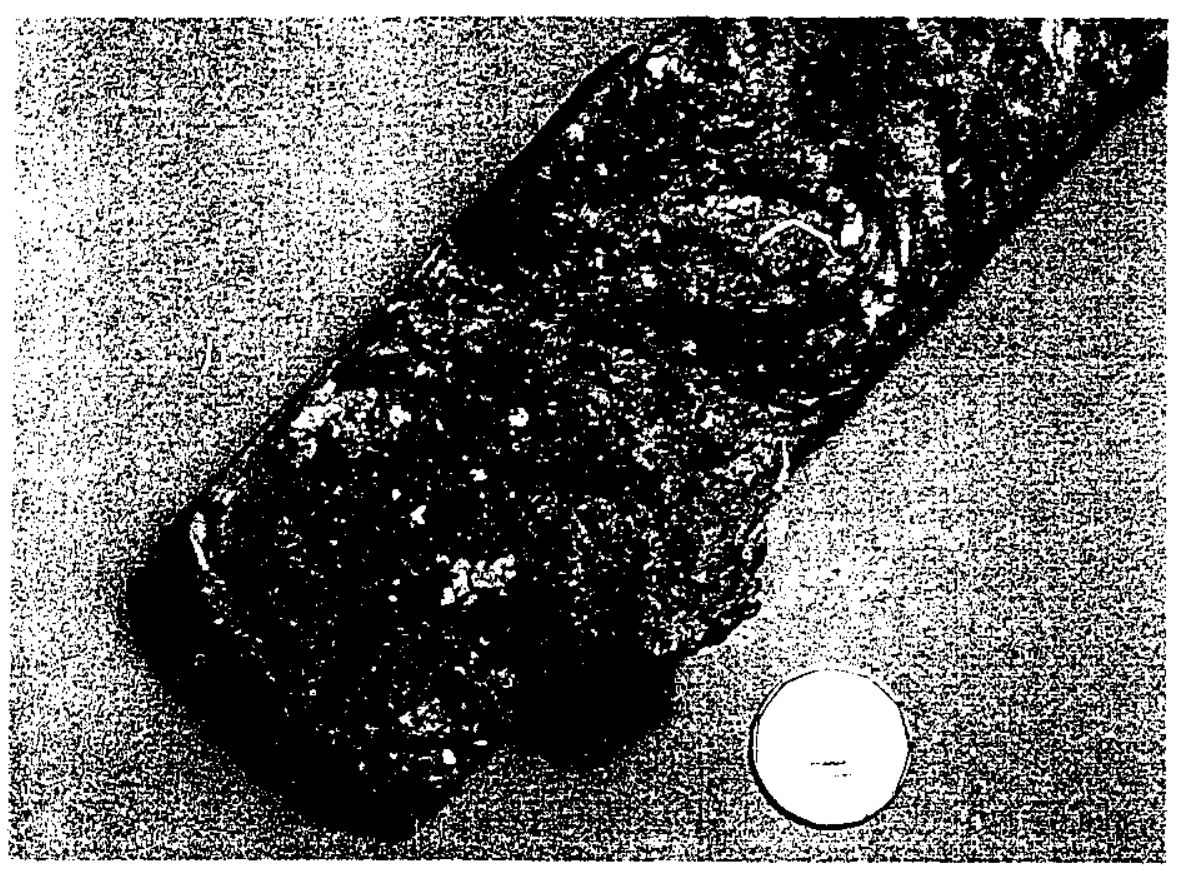

Figure 30 Metal ingot (L,ismuth addition) 


\section{VI.2 XRD ANALYSIS OF POWDER RESIDUE}

The powder residue was analyzed by X-Ray Diffraction (XRD) for qualitative identification of the crystalline compounds. The automated Phillips APD 1700(39) system searched various combinations of the more intense diffraction lines until a match was found. All species that "scored high erough" to be positively identified by the Phillips system are noted by an asterisk* and are tabulated by name, compound formula and identification number, Table $\mathrm{XXX}$. The XRD analysis showed that the powder residue was composed of various compounds. The compounds present in the powder residue included: Strontium Carbonate, Aluminum, Alumina, Aluminum Carbide, Spinel, Strontium Oxide, Periclase and Bismuth Oxide.

XRD analysis was also performed on the condensate. Results showed only the presence of synthetic periclase and bismuth oxide in Experiments 1 to 5 and 6 to 8, respectively. The condensates were obviously formed by evaporation of the respective metal followed by condensation and oxidation. Some metallic vapour escaped through various openings in the crucible cap. There was no evidence of strontium metal or strontium compounds in the condensate. 
Table XXX XRD Results for Powder Residue

\begin{tabular}{|c|c|c|c|c|c|c|}
\hline & \multicolumn{5}{|c|}{ EXPERIMENT \# } \\
\hline SPECIES & 0 & 1 & 3 & 5 & 6 & 8 \\
\hline Aluminum, Al 4-787 & $*$ & $*$ & $*$ & $*$ & $*$ & $*$ \\
\hline $\begin{array}{c}\text { Strontianite, Syn. SrCO3 } \\
\text { 5-418 }\end{array}$ & $*$ & $*$ & $*$ & $*$ & $*$ & $*$ \\
\hline $\begin{array}{c}\text { Corundum, Syn. Al2O3 } \\
10-173\end{array}$ & $*$ & $*$ & $*$ & $*$ & $*$ & $*$ \\
\hline $\begin{array}{c}\text { Aluminum Carbide } \\
\text { Al4C3 11-629 }\end{array}$ & $*$ & $*$ & $*$ & $*$ & $*$ & $*$ \\
\hline $\begin{array}{c}\text { Spinel, Syn. } \\
\text { MgO Al2O3 21-1152 }\end{array}$ & $*$ & $*$ & $*$ & $*$ & & \\
\hline $\begin{array}{c}\text { Strontium Oxide } \\
\text { SrO 27-1304 }\end{array}$ & $*$ & & $*$ & & \\
\hline $\begin{array}{c}\text { Periclase, Syn. } \\
\text { MgO 4-829 }\end{array}$ & & $*$ & & & & \\
\hline $\begin{array}{c}\text { Bismuth Oxide } \\
\text { Bi2O3 18-244 }\end{array}$ & & & & & $*$ & $*$ \\
\hline \multicolumn{2}{|c|}{ Positively Identified } & & & \\
\hline
\end{tabular}




\section{VI.3 ATOMIC ABSORPTION ASSAYS}

Atomic absorption spectrophotometry was used to chemically assay all reaction products. This method is well suited to the determination of strontium and many other metals and is very sensitive although the spectral and chemical interferences for the element to be analyzed must be known. Literature reveals that the results obtained are rigorously dependent on the analytical conditions. Possible interferences encountered with atomic absorption are; spectral interferences, ionization interferences, refractory compound formation, matrix effects and physical characteristics of the solution. Therefore, it is important to know the characteristics of each element to prepare standard and sample in order to obtain optimum results.

During strontium analysis, care had to be taken in order to minimize interferences and the depression due to the absorbance by aluminum. Previous research ${ }^{(40)}$ found that alkali metals added to a strontium solution will enhance the signal. All solutions were prepared with $\mathrm{HCl}$ and $\mathrm{H}_{2} \mathrm{SO}_{4}$ which showed no effect on the absorbance of strontium ${ }^{(40)}$. The interference caused by aluminum was controlled by adding $1 \% \mathrm{w} / \mathrm{v}\left(2.67 \mathrm{~g}\right.$ of $\mathrm{LaCl}_{3} 7 \mathrm{H}_{2} \mathrm{O}$ per $100 \mathrm{ml}$ of solution $)$ lanthanum ${ }^{(40 \times 41 \times 42)}$. The presence of magnesium had positive interference for strontium analysis ${ }^{(41)(42)(43 \times 44)}$. Bismuth had no effect on the strontium assays ${ }^{(45)}$. 


\section{VI.3.1 Sample Preparation}

The sampling method was different for each reaction product obtained. The samples from the ingots were cbtained by drilling to produce shavings from various areas in order to prevent or minimize segregation. Pieces of dross were taken randomly and cut into smaller ones to form the sample. The powder residue was mixed and a small sample withdrawn randomly and cumulatively to obtain the sample. The condensate was collected from the crucible cap (condenser) by brushing off the very fine dust.

\section{VI.3.2 Atomic Absorption Results}

Tables $\mathrm{XXX1}$ to $\mathrm{XXXV}$ list the results for the reaction product assays. Table XXXI presents an example of data obtained from a particular set of strontium standards as well as the assay for the ingot samples. This table also indicates the mean $(\bar{x})$ and the standard deviation (s), according to Equation 25:

$$
\text { Standard Deviation }=s=\sqrt{\frac{\sum_{i}\left(x_{i}-\bar{x}\right)^{2}}{(n-1)}}
$$

The concentrations, $\mathrm{C}$ and the error in concentration, $\Delta \mathrm{C}$, were determined according to the method presented in Chapter VII below. 
Table XXXI Data of Standards and Ingots Assays

\begin{tabular}{|c|ccc|c|c|}
\hline $\begin{array}{c}\text { Standard } \\
\text { ppm of Sr }\end{array}$ & Absorbance $(\mathrm{x})$ & $\begin{array}{c}\text { Average } \\
(\mathrm{x})\end{array}$ & $\begin{array}{c}\text { Standard } \\
\text { Deviation (s) }\end{array}$ \\
\hline 0 & 0.004 & 0.005 & 0.005 & 0.005 & 0.001 \\
2 & 0.098 & 0.099 & 0.099 & 0.099 & 0.001 \\
4 & 0.201 & 0.199 & 0.203 & 0.201 & 0.002 \\
8 & 0.397 & 0.398 & 0.399 & 0.398 & 0.001 \\
\hline 0 & 0.041 & 0.039 & 0.042 & 0.040 & 0.002 \\
1 & 0.026 & 0.027 & 0.027 & 0.027 & 0.001 \\
2 & 0.045 & 0.046 & 0.045 & 0.045 & 0.001 \\
3 & 0.055 & 0.055 & 0.056 & 0.055 & 0.001 \\
4 & 0.062 & 0.064 & 0.063 & 0.063 & 0.001 \\
5 & 0.098 & 0.101 & 0.098 & 0.099 & 0.002 \\
6 & 0.046 & 0.046 & 0.048 & 0.046 & 0.001 \\
7 & 0.023 & 0.025 & 0.024 & 0.024 & 0.001 \\
8 & 0.043 & 0.044 & 0.043 & 0.043 & 0.001 \\
\hline
\end{tabular}

Table XXXII Assays of Ingot

\begin{tabular}{|c|c|c|c|c|c|c|c|}
\hline Exp. \# & $\begin{array}{c}\mathrm{Mg}: \mathrm{Sr} \\
\text { Molar } \\
\text { Ratio }\end{array}$ & $\begin{array}{c}\mathrm{C}_{\mathrm{Sr}} \\
(\mathrm{wt} \%)\end{array}$ & $\begin{array}{c}\Delta \mathrm{C}_{\mathrm{Sr}} \\
(\mathrm{wt} \%)\end{array}$ & $\begin{array}{c}\text { Rel. Err. } \\
(\%)\end{array}$ & $\begin{array}{c}\mathrm{C}_{\mathrm{Mg}_{\mathrm{g}}} \\
(\mathrm{wt} \%)\end{array}$ & $\begin{array}{c}\Delta \mathrm{C}_{\mathrm{Mg}} \\
(\mathrm{wt} \%)\end{array}$ & $\begin{array}{c}\text { Rel. Err. } \\
(\%)\end{array}$ \\
\hline 0 & 0 & 0.08 & 0.007 & 8.3 & - & - & - \\
1 & 2 & 0.53 & 0.047 & 9.0 & 1.24 & 0.169 & 13.6 \\
2 & 4 & 0.93 & 0.047 & 5.1 & 2.79 & 0.169 & 6.0 \\
3 & 6 & 1.09 & 0.047 & 4.3 & 4.46 & 0.178 & 4.0 \\
4 & 8 & 1.26 & 0.048 & 3.8 & 5.33 & 0.169 & 3.2 \\
5 & 10 & 1.97 & 0.068 & 3.4 & 7.49 & 0.179 & 2.4 \\
\hline Exp.\# & Bi Add. & $\mathrm{C}_{\mathrm{Sr}}$ & $\Delta \mathrm{C}_{\mathrm{Sr}}$ & Rel. Err. & $\mathrm{C}_{\mathrm{Bl}}$ & $\Delta \mathrm{C}_{\mathrm{Bl}}$ & Rel. Err. \\
& $(\mathrm{wt} \%)$ & $(\mathrm{wt} \%)$ & $(\mathrm{wt} \%)$ & $(\%)$ & $(\mathrm{wt} \%)$ & $(\mathrm{wt} \%)$ & $(\%)$ \\
\hline 6 & 1 & 0.95 & 0.048 & 5.0 & 0.87 & 0.194 & 22.3 \\
7 & 3 & 0.48 & 0.048 & 9.8 & 2.61 & 0.153 & 5.9 \\
8 & 6 & .0 .85 & 0.048 & 5.6 & 5.08 & 0.153 & 3.0 \\
\hline
\end{tabular}


Table XXXIII Assays of Dross

\begin{tabular}{|c|c|c|c|c|c|c|c|}
\hline Exp. \# & $\begin{array}{c}\text { Mg:Sr } \\
\text { Molar } \\
\text { Ratio }\end{array}$ & $\begin{array}{c}\mathrm{C}_{\mathrm{Sr}} \\
(\mathrm{wt} \%)\end{array}$ & $\begin{array}{c}\Delta \mathrm{C}_{\mathrm{Sr}} \\
(\mathrm{wt} \%)\end{array}$ & $\begin{array}{c}\text { Rel. Err. } \\
(\%)\end{array}$ & $\begin{array}{c}\mathrm{C}_{\mathrm{Mg}_{\mathrm{g}}} \\
(\mathrm{wt} \%)\end{array}$ & $\begin{array}{c}\Delta \mathrm{C}_{\mathrm{Mg}_{\mathrm{g}}} \\
(\mathrm{wt} \%)\end{array}$ & $\begin{array}{c}\text { Rel. Err. } \\
(\%)\end{array}$ \\
\hline 0 & 0 & 5.15 & 0.134 & 2.6 & - & - & - \\
1 & 2 & 6.34 & 0.066 & 1.0 & 3.33 & 0.333 & 9.9 \\
2 & 4 & 6.66 & 0.122 & 1.8 & 4.34 & 0.345 & 7.9 \\
3 & 6 & 6.46 & 0.095 & 1.5 & 4.83 & 0.338 & 7.0 \\
4 & 8 & 7.04 & 0.107 & 1.5 & 5.81 & 0.326 & 5.6 \\
5 & 10 & 7.39 & 0.152 & 2.1 & 6.44 & 0.342 & 5.3 \\
\hline Exp.\# & Bi Add. & $\mathrm{C}_{\mathrm{Sr}}$ & $\Delta \mathrm{C}_{\mathrm{St}}$ & Rel. Err. & $\mathrm{C}_{\mathrm{Bl}}$ & $\Delta \mathrm{C}_{\mathrm{B}}$ & Rel. Err. \\
& $(\mathrm{wt} \%)$ & $(\mathrm{wt} \%)$ & $(\mathrm{wt} \%)$ & $(\%)$ & $(\mathrm{wt} \%)$ & $(\mathrm{wt} \%)$ & $(\%)$ \\
\hline 6 & 1 & 5.27 & 0.094 & 1.8 & 0.62 & 0.055 & 8.9 \\
7 & 3 & 8.56 & 0.110 & 1.3 & 0.83 & 0.070 & 8.4 \\
8 & 6 & 12.38 & 0.110 & 0.9 & 0.76 & 0.070 & 9.2 \\
\hline
\end{tabular}

Table XXXIV Assays of Powder

\begin{tabular}{|c|c|c|c|c|c|c|c||}
\hline Exp. \# & $\begin{array}{c}\text { Mg:Sr } \\
\text { Molar } \\
\text { Ratio }\end{array}$ & $\begin{array}{c}\mathrm{C}_{\mathrm{Sr}} \\
(\mathrm{wt} \%)\end{array}$ & $\begin{array}{c}\Delta \mathrm{C}_{\mathrm{Sr}} \\
(\mathrm{wt} \%)\end{array}$ & $\begin{array}{c}\text { Rel. Err. } \\
(\%)\end{array}$ & $\begin{array}{c}\mathrm{C}_{\mathrm{Mg}_{\mathrm{g}}} \\
(\mathrm{wt} \%)\end{array}$ & $\begin{array}{c}\Delta \mathrm{C}_{\mathrm{Mg}_{8}} \\
(\mathrm{wt} \%)\end{array}$ & $\begin{array}{c}\text { Rel. Err. } \\
(\%)\end{array}$ \\
\hline 0 & 0 & 11.26 & 1.40 & 3.7 & - & - & - \\
1 & 2 & 37.42 & 1.39 & 3.8 & 2.98 & 0.421 & 14.1 \\
2 & 4 & 42.21 & 1.61 & 2.3 & 4.60 & 0.410 & 8.9 \\
3 & 6 & 50.83 & 1.18 & 5.7 & 4.36 & 0.422 & 9.7 \\
4 & 8 & 24.59 & 1.40 & 11.0 & 7.22 & 0.422 & 5.8 \\
5 & 10 & 33.29 & 3.65 & 6.4 & 13.52 & 1.127 & 8.3 \\
\hline Exp.\# & Bi Add. & $\mathrm{C}_{\mathrm{Sr}}$ & $\Delta \mathrm{C}_{\mathrm{Sr}}$ & Rel. Err. & $\mathrm{C}_{\mathrm{Bl}}$ & $\Delta \mathrm{C}_{\mathrm{Bl}}$ & Rel. Err. \\
& $(\mathrm{wt} \%)$ & $(\mathrm{wt} \%)$ & $(\mathrm{wt} \%)$ & $(\%)$ & $(\mathrm{wt} \%)$ & $(\mathrm{wt} \%)$ & $(\%)$ \\
\hline 6 & 1 & 21.72 & 1.39 & 6.4 & 5.27 & 1.05 & 19.9 \\
7 & 3 & 24.58 & 1.18 & 4.8 & 5.12 & 1.07 & 21.0 \\
8 & 6 & 37.96 & 6.98 & 18.4 & 16.26 & 3.88 & 23.9 \\
\hline
\end{tabular}


Table XXXV Strontium Assays from Kinetics

\begin{tabular}{|c|c|c|c|c||}
\hline \hline Exp.\# & $\begin{array}{c}\text { Mg:Sr } \\
\text { Molar Ratio }\end{array}$ & 20 minutes & 40 minutes & 60 minutes \\
\cline { 3 - 5 } & & $\mathrm{C}_{\mathrm{Sr}}(\mathrm{wt} \%)$ & $\mathrm{C}_{\mathrm{Sr}}$ (wt\%) & $\mathrm{C}_{\mathrm{Sr}}$ (wt\%) \\
\hline 0 & 0 & 0.12 & 0.17 & 0.08 \\
1 & 2 & 0.29 & 0.37 & 0.53 \\
2 & 4 & 0.25 & 0.34 & 0.93 \\
3 & 6 & 0.24 & 0.49 & 1.09 \\
4 & 8 & 0.15 & 0.57 & 1.26 \\
5 & 10 & 0.33 & 0.72 & 1.97 \\
\hline Exp.\# & Bi Add. & & & \\
& (wt\%) & & & \\
\hline 6 & 1 & 0.29 & 0.62 & 0.95 \\
7 & 3 & 0.26 & 0.73 & 0.49 \\
8 & 6 & 0.36 & 0.57 & 0.85 \\
\hline
\end{tabular}




\section{VI.4 OPTICAL MICROSCOPE EXAMINATIONS}

Polished ingot saniples were examined under an optical microscope in order to visualize the change in the microstructure $w$. The change in the strontium content. Figures 31 to 34 show the microstructure of the ingots (Magnitication 350X). It can be observed that more intermetallic phases were present in the satuple as tha $\mathrm{Mg}: \mathrm{Sr}$ molar ratio increased. The presence of intermetallic phasec wa; also observed for the bismuth addit:ons but in very small quantity. SEM analysis confirmed the presence of strontium in the intermetallic phases (see nexi Section). This impiies that surontient carbonate was reduced to strontium which dissolved into the aluminummagnesium reductant. It can be seen that increasing the $\mathrm{Mg}: \mathrm{Sr}$ molar ratio improved the extraction while bismuth additions did not.

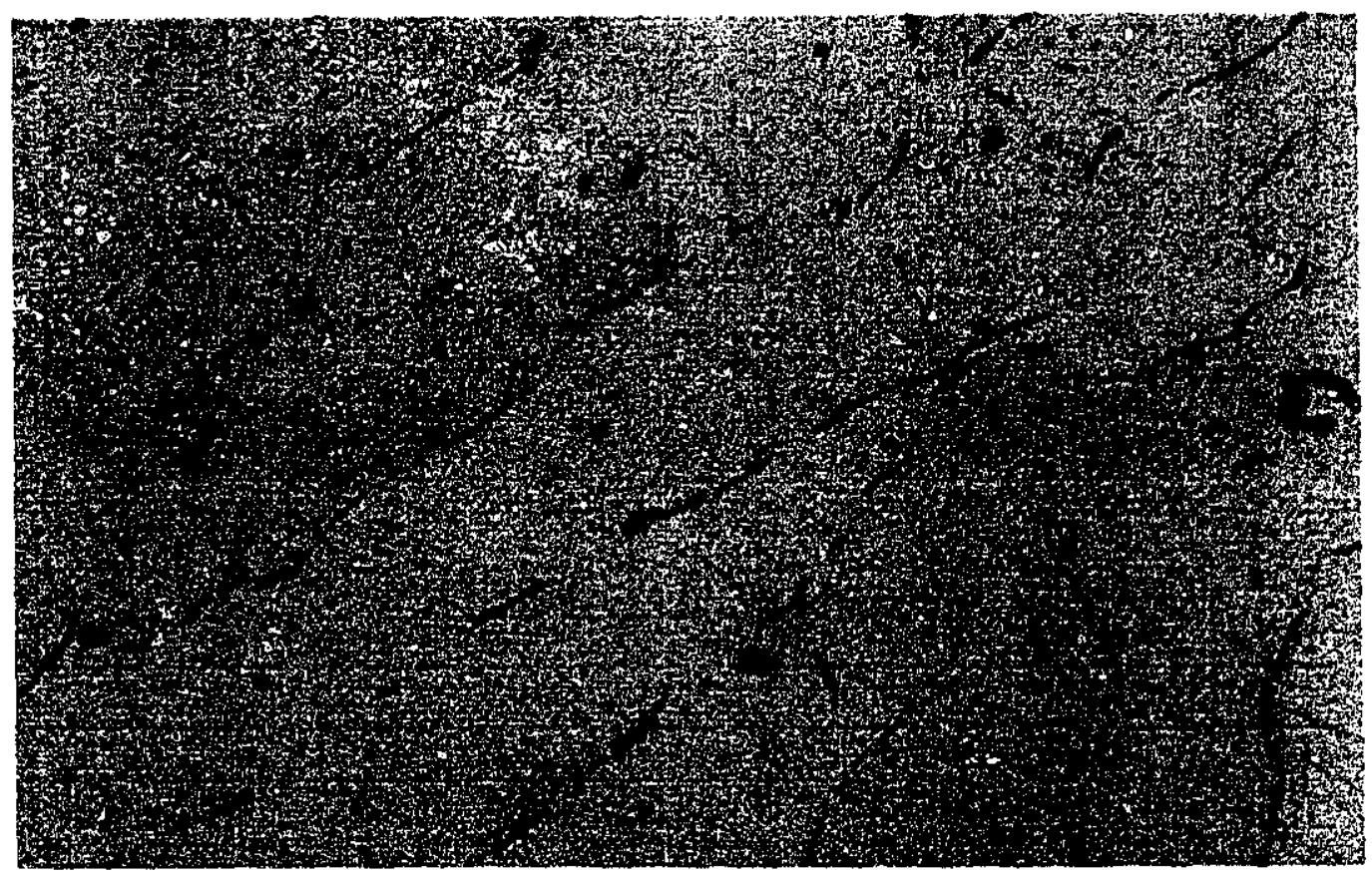

Figure 31 Microstructure of the ingot for Experiment 0 (0Mg:Sr) 


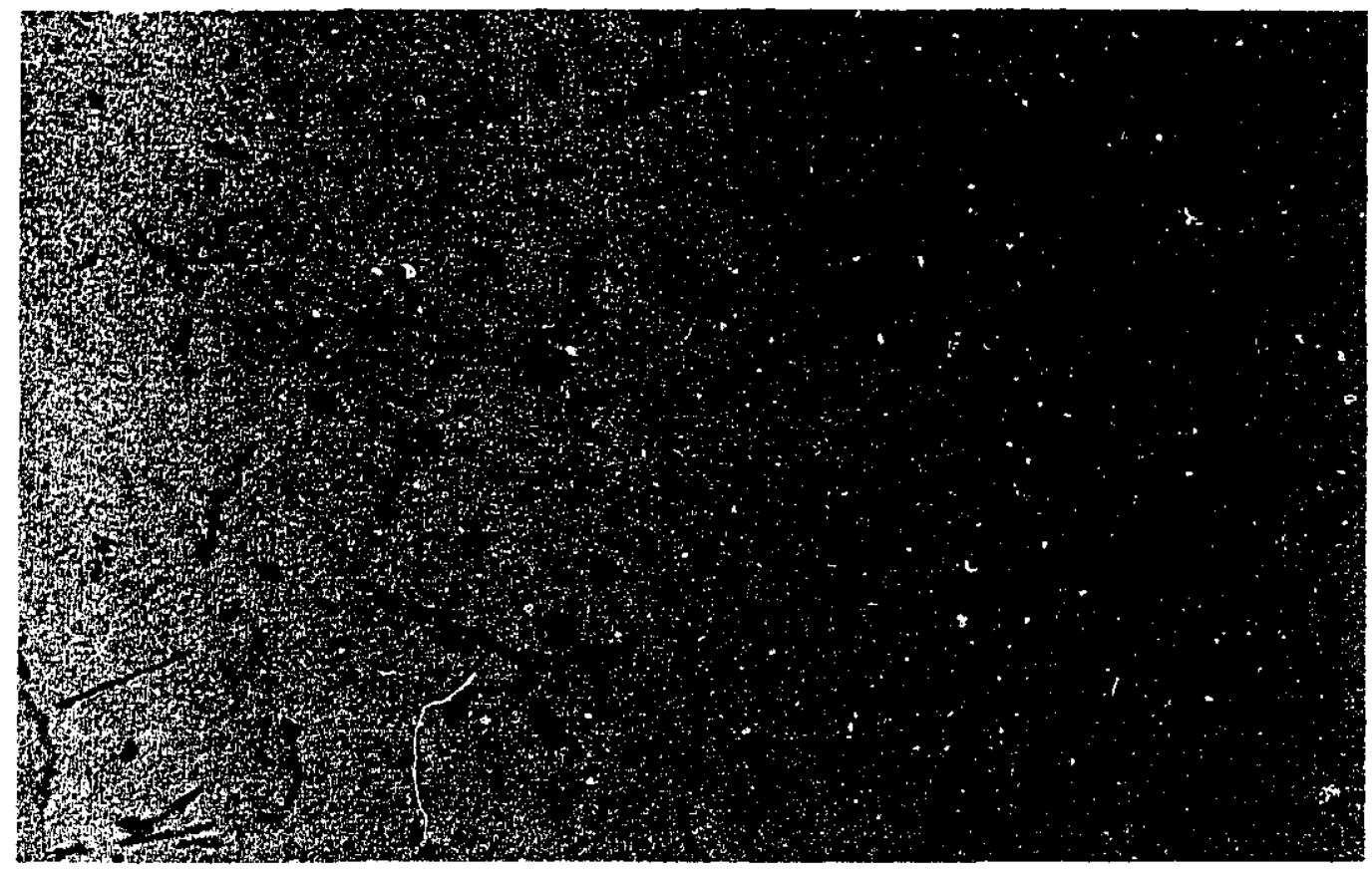

Figure 32 Microstructure of the ingot for Experiment 3 (6Mg:Sr)

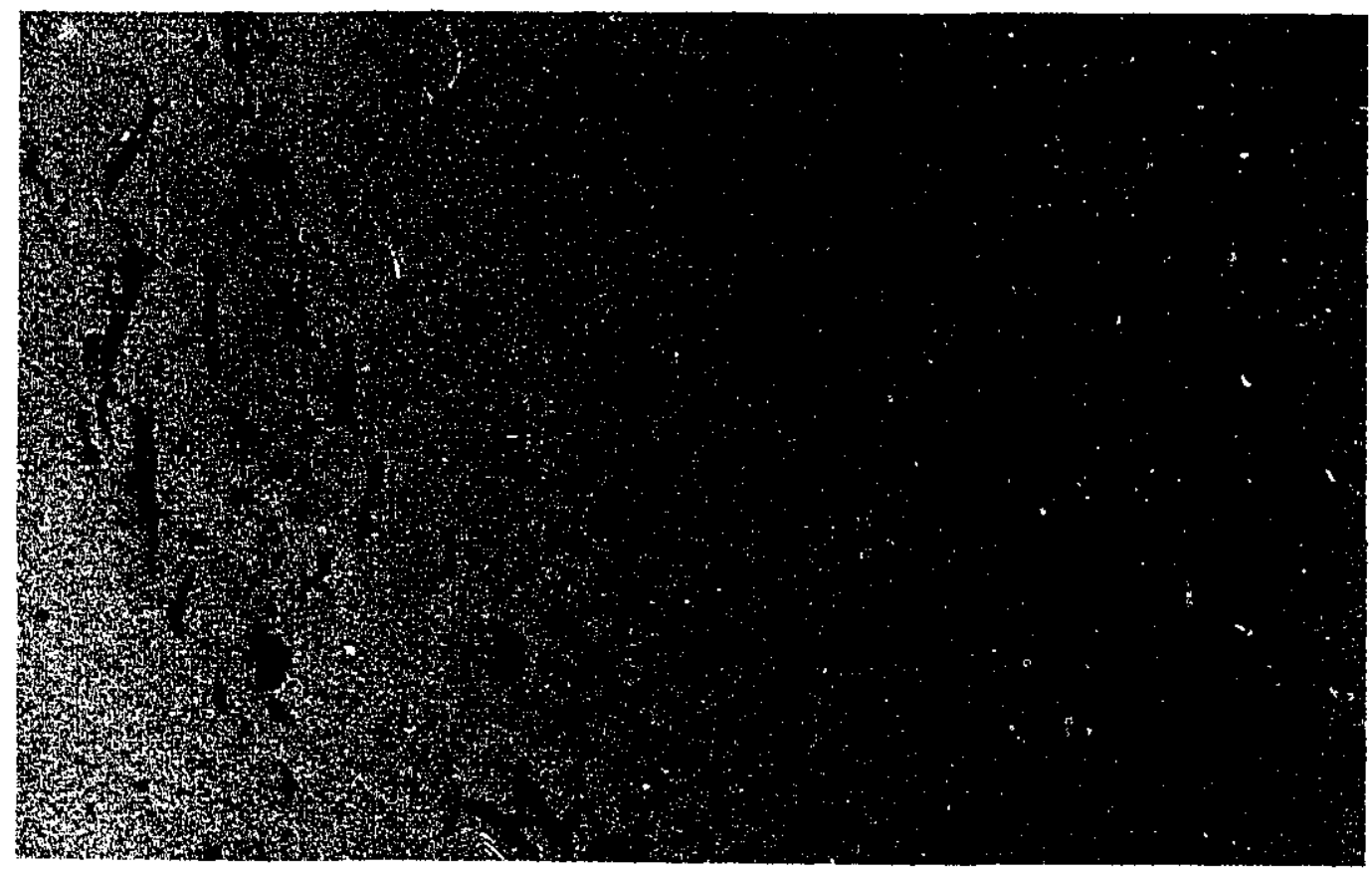

Figure 33 Microstructure of the ingot for Experiment 5 (10Mg:Sr) 


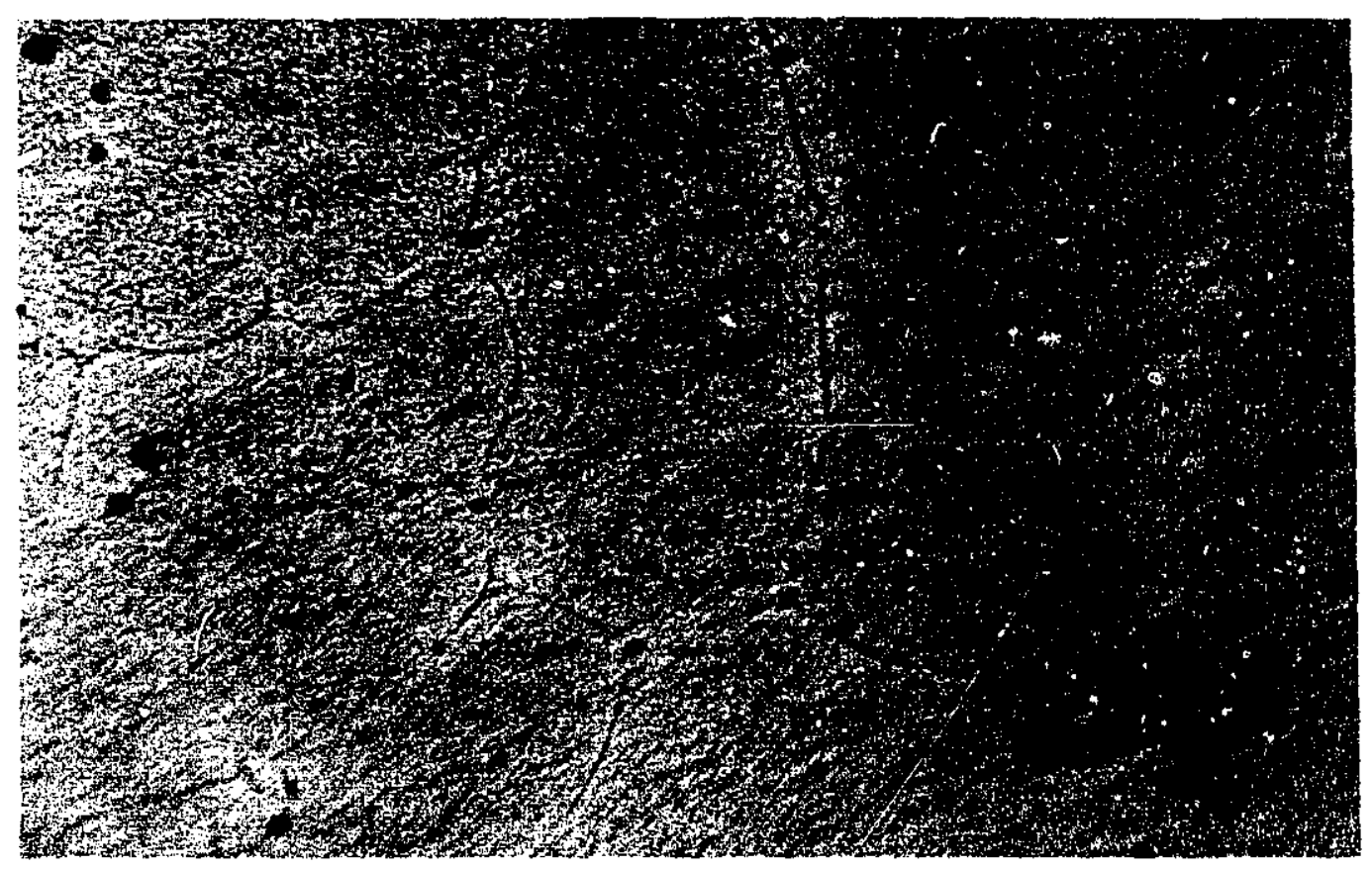

Figure 34 Microstructure of the ingot for Experiment 8 (6 Wt\% Bi) 


\section{VI.5 SCANNING ELECTRON MICROSCOPE ANALYSIS}

The scanning electron microscope used was a JEOL JSM-T300(4) linked to the SQ program of the Tracor Northern TN-5400 software analysis system ${ }^{(47)}$. This system permitted analysis of small areas on the sample surface. The major drawback of this instrument is the detector which is protected with a beryllium window making oxygen detection impossible ${ }^{(48)}$. Therefore, it was not possible to differentiate between pure species and compounds formed with oxygen. The SEM was used to examine the reaction products in order to find evidence of reaction between the strontium source material and the molten reductant. Qualitative and semiquatitative results have been obtained from the study.

The analysis of the ingot from Experiment 5 was performed to obtain more information about the intermetallic phase observed under the optical microscope. Table XXXVI gives the average semi-quantitative analysis results obtained. The phase observed was presumably intermetallic since it created relief during polishing (intermetallic usually shows poor ductility) permitting observation according to the optical microscope principles ${ }^{(49)}$.

Table XXXVI SEM Assay of Intermetallic (Weight \%)

\begin{tabular}{|c|c|c|}
\hline ALUMINUM & MAGNESIUM & STRONTIUM \\
\hline 76.5 & 1.2 & 22.3 \\
\hline
\end{tabular}


It was found that some strontium was present in the intermetallic but the intermetallic itself was not identified. Possible intermetallics which could be formed with stontium in presence of aluminum and magnesium are identified in phase diagrams, Appendix B.

The powder residue examinations did not show details of the possible interface between the solid and the liquid phase. Observation of distinct reaction zones between the strontium source material (solid) and the reductant (liquid) could have brought other valuable information concerning the reaction mechanisms. However, the dross residue showed interesting details. Figure 35 shows the surface of a piece of dross.

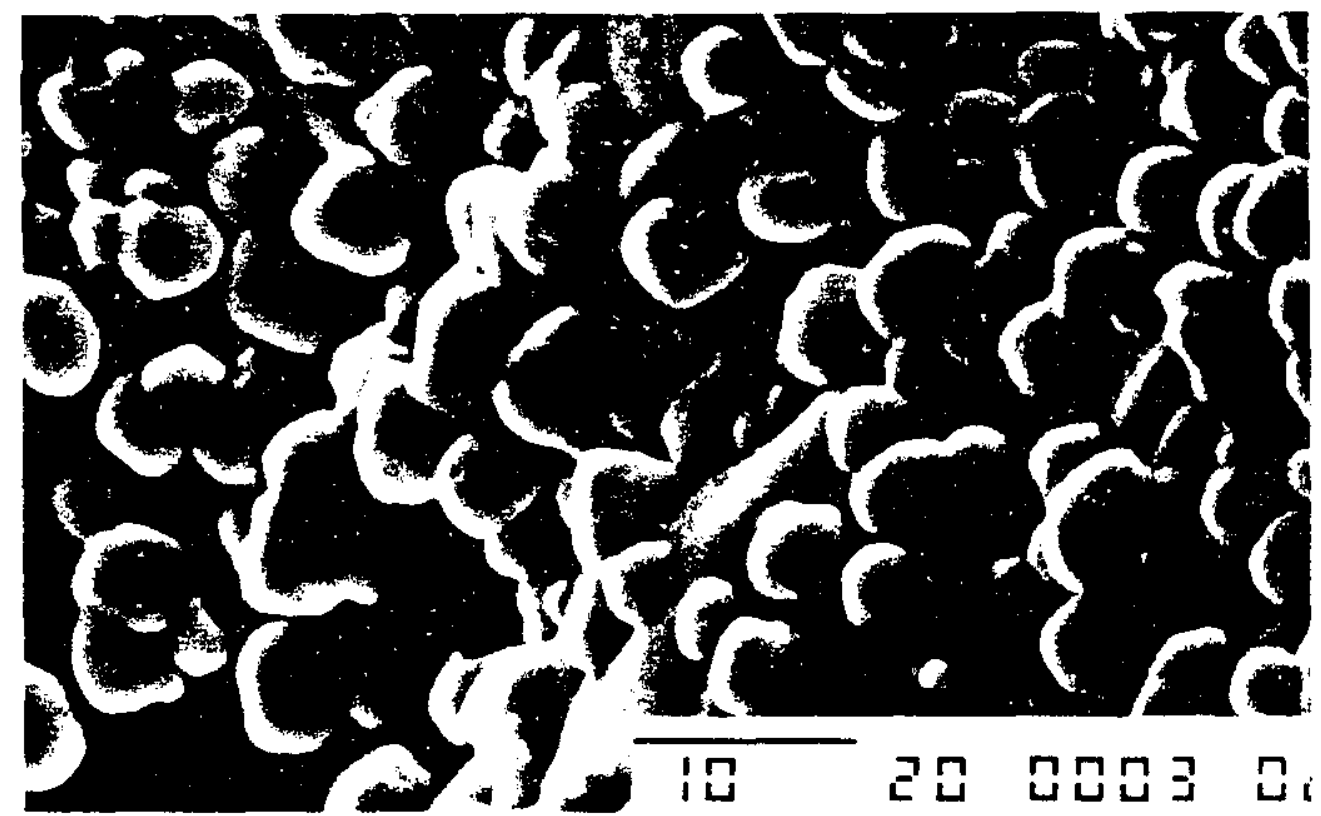

Figure 35 Dross Surface $(1500 \mathrm{X})$

Small particles averaging $5 \mu \mathrm{m}$ in diameter were observed on the dross surface. Spot analysis on the SEM showed that the particles were aluminum. These particles could have been formed during the mixing and under the magnetic field of the furnace. Furthermore, these droplets were certainly oxidized during the process. The aluminum oxide layer on the droplet 
surface and/or the melt surface prevented wetting of the droplets at this temperature ${ }^{(50)}$. These particles or nodules were found on the surface of the dross, in its cavities and folds and trapped inside. The particles which were free became part of the powder product and were recuperated at the end of the experiment. Figures 36 and 37 show the condensate obtained with magnesium addition (Experiments 0 to 5) and bismuth addition (Experiments 6 to 8), respectively. The condensate obtained with magnesium and with bismuth addition presented the same physical appearance when observed with the SEM. The condensates were made of very fine paiticles.

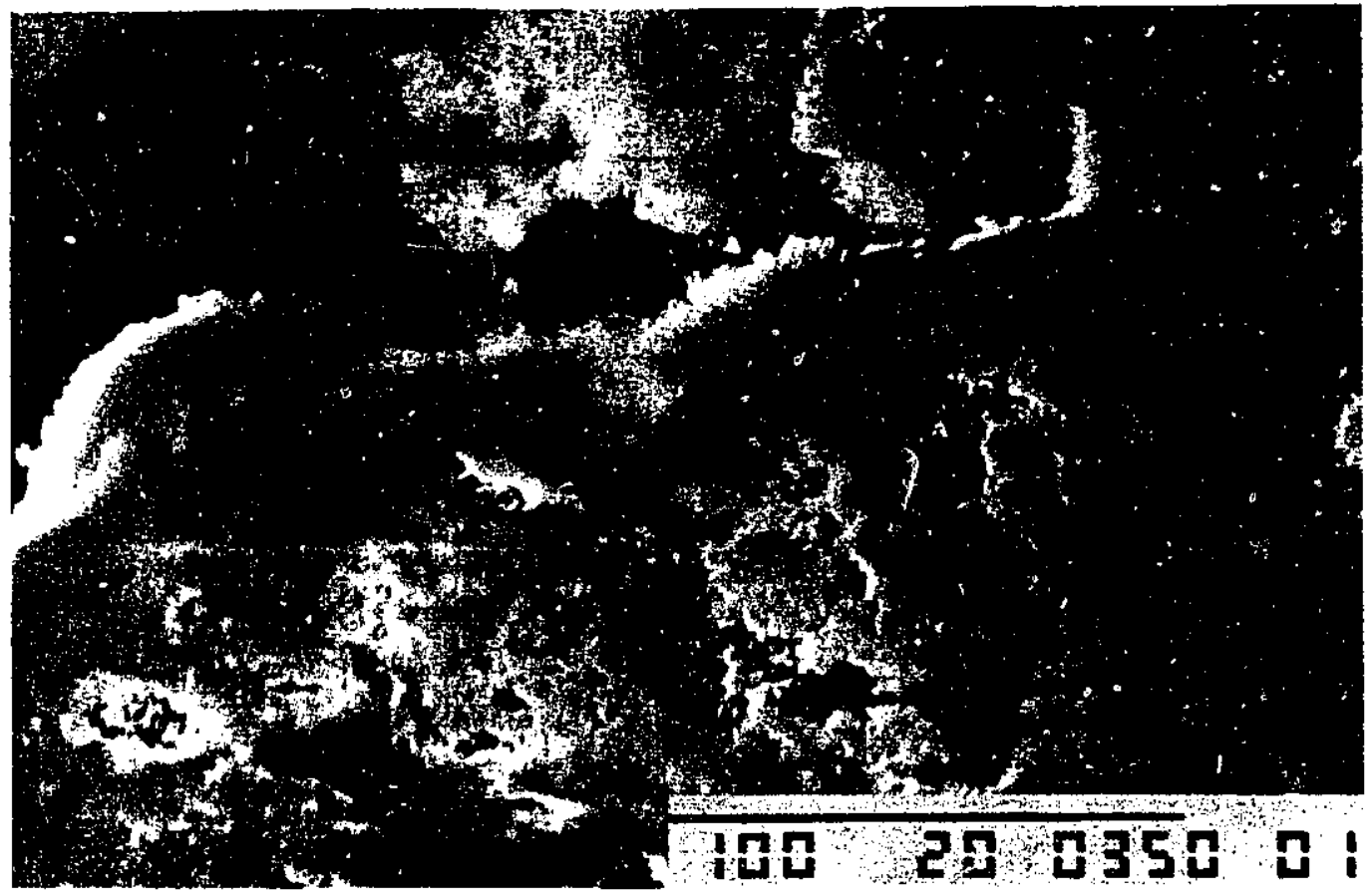

Figure 36 Condensate for Experiments 1 to 5 (350 X) 


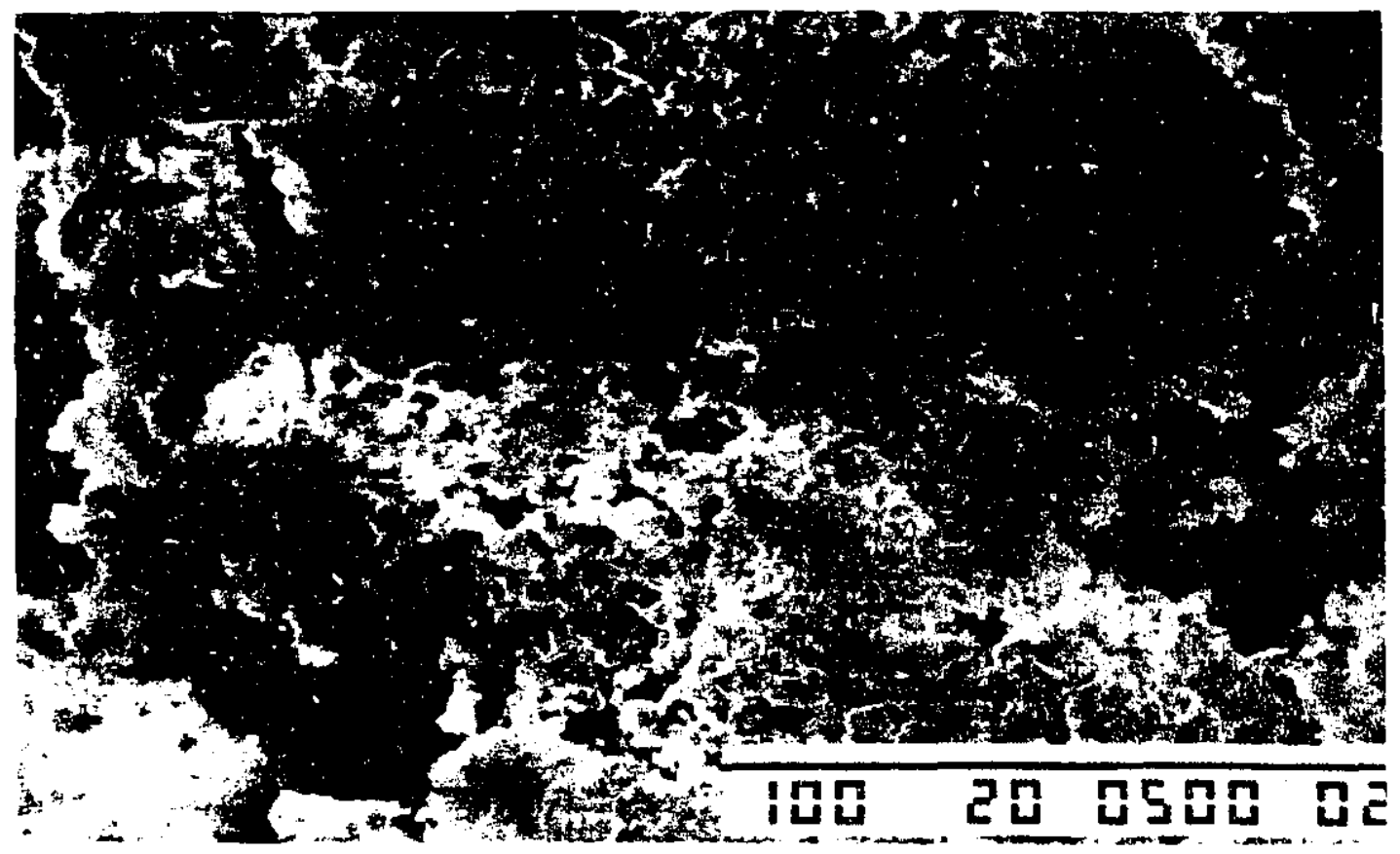

Figure 37 Condensate for Experiments 6 to 8 (350 X) 


\section{CALCULATIONS}

\section{VII.1 EXAMPLE CALCULATIONS OF CHEMICAL ASSAYS}

The method of least squares which was available as a suoroutine in the spreadsheet package, QUATTRO $\mathrm{PRO}^{(51)}$, was used in the calibration of the Atomic Absorption Spectrophotometer to find the "best-fit" line between the concentration ( $X$ values) and the absorbance readings ( $Y$ values). The method of least squares assumes that the errors in the $y$ values are substantially greater than the errors in the $x$-values ${ }^{(52)}$. An example of a calibration curve derived from the regression lines is shown in Figure 38. Table XXXVII shows the linear regression results obtained from data in Table XXXI.

Table XXXVII Example of Linear Regression Results from QUATTRO PRO ${ }^{(51)}$

\begin{tabular}{|l|c|}
\hline Constant $(\mathrm{b})$ & 0.000 \\
Standard Error of Y Estimate $(\Delta \mathrm{Y})$ & 0.001 \\
R Squared & 0.999 \\
Number of Observations & 3 \\
Degrees of Freedom & 2 \\
Slope $(\mathrm{m})$ & 0.049 \\
Standard Error of Slope $(\Delta \mathrm{m})$ & 0.001 \\
\hline
\end{tabular}




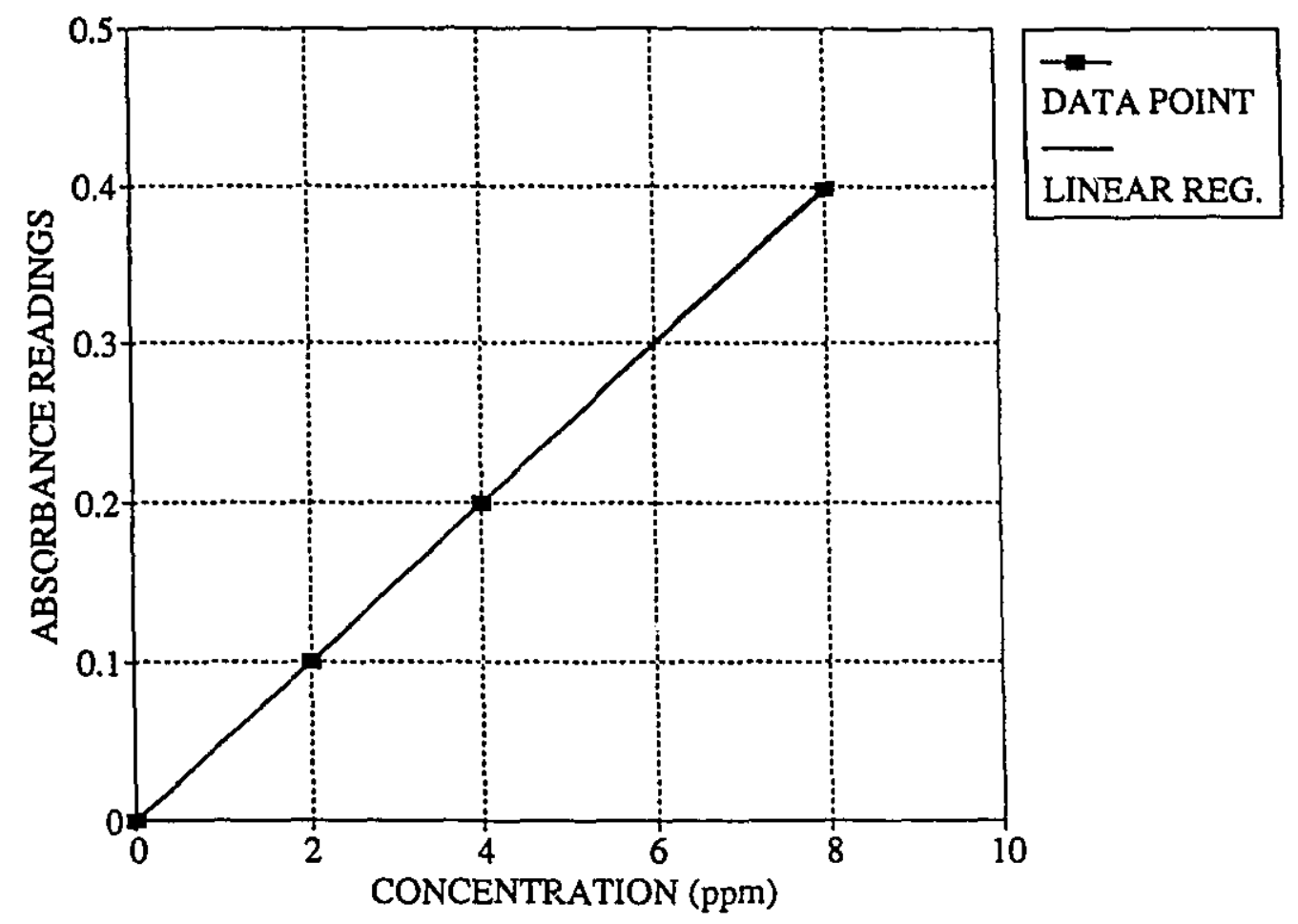

Figure 38 Calibration Curve

The unknown concentration of a species in a solution was determined from its absorbance readings in the A.A. In the calculation the $y$-intercept was forced to zero, the absorbance of a distilled water solution. The equation of the line is then represented by

$$
Y=m X
$$

where $\mathrm{m}$ is the slope and the concentration and the absorbance are $\mathrm{X}$ and $\mathrm{Y}$, respectively. Rearranging the Equation 26, the concentration of the sample solutions was determined according to

$$
X-\frac{Y}{m}
$$


However, to calculate the sample assays from the concentrations obtained with the atomic absorption, other calculations were required. These calculations were performed by taking into account the dilution factor, sample mass and the solution volumes. The following calculations, performed for the ingot from the Experiment 4, determined strontium concentration.

From Table XXXI, the absorbance, Y, obtained was 0.063 , thus the strontium concentration of the original sample was determined as follows:

i) Strontium concentration of the solution

From Table XXXVII, $\mathrm{m}=0.05$

Using Equation $26, \mathrm{X}=0.063 / 0.05=1.26 \mathrm{ppm} \mathrm{Sr}$ or $1.26 \mathrm{mg} \mathrm{Sr} / \mathrm{h}$

ii) Dilution factor

The solution was diluted 10 times, thus the initial solution concentration was

$10 \times 1.26 \mathrm{mg} \mathrm{Sr} / 1=12.6 \mathrm{mg} \mathrm{Sr} / 1$

The volume of the initial solution was 1 liter, therefore

1 liter $\times 12.6 \mathrm{mg} \mathrm{Sr} / 1=12.6 \mathrm{mg}$ of Sr

iii) Sample mass

The solution was obtained by dissolving $1002.7 \mathrm{mg}$ of sample which gives the concentration of the original sarnple as

$(12.6 \mathrm{mg} \mathrm{Sr} / 1002.7 \mathrm{mg}) * 100=1.26 \mathrm{wt} \% \mathrm{Sr}$ 


\section{VII.2 SAMPLING AND ANALYTICAL ERRORS}

Many factors contributed to the overall error in the sample assays. The sampling operation is one which could influence the final assay results. However, random sampling and preparation of a composite sample were two ways to obtain representative samples of the material for analysis ${ }^{(53)}$. Another factor was the analytical error. This had two components: the error in the calibration curve and the error in repeated absorbance readings for anyone particular solution. From the linear regression obtained from QUATTRO PRO ${ }^{(51)}$, Table XXXVII, the standard deviation for the calibration curve was given by the standard error of the y-estimate which was 0.0014 units of absorbance. Using the following equation, the standard deviation for the calibration curve can be converted to a standard deviation in the concentration.

$$
\Delta C_{R E G}=\left(\frac{S_{Y}}{m}\right)
$$

where $\Delta \mathrm{C}_{\mathrm{REG}}$, is the stanciard deviation in concentration due to the standard deviation of the calibration curve, $S_{Y}$ is the standard deviation of the $y$-estimate and $m$ is the slope of the calibration curve obtained from the regression.

The data for Experiment 4 indicated the standard deviation for strontium concentration readings, $S_{Y}$, to be $0.028 \mathrm{ppm}$.

By replacing $S_{Y}$ in Equation 32 by the error in the solution absorbance readings, Table $\mathrm{XXXI}$, the standard deviation in the concentration readings can be determined. For Experiment 4, the standard deviation of the readings was 0.001 which yields a standard deviation in the concentration of $0.02 \mathrm{ppm}$. Therefore, the total error in the concentration, $\Delta \mathrm{C}$, for the ingot 
sample of Experiment 4 is given by the following equation.

$$
\Delta C=\Delta C_{R E G}+\Delta C_{R E A D}
$$

where $\quad \Delta \mathrm{C}_{\mathrm{REG}}$ : Error in concentration from errors in the calibration surve

$\Delta C_{R E A D}:$ Error in concentration from variance in the readings

thus,

$$
0.028+0.001=0.029 \mathrm{ppm} \mathrm{Sr}
$$

The relative error is then obtained as

$$
(0.029 / 1.26) \times 100=2.3 \% \text { of the reading }
$$

and represents the error in the strontium reading for Experiment 4. Other sources of error such as mass and volume measurements were considered to have less impact on the relative error. 


\section{DISCUSSION}

\section{VIII.1 INTRODUCTION}

Experimental results obtained from the reduction experiments have shown various levels of istrontium extraction. The objectives of the discussion are to comment on the following:
a) Experimental Program
b) Experimental Procedures
c) Comparison of Ingot Assay Results with those of an Outside Laboratory
d) Mass Balances for $\mathrm{Sr}, \mathrm{Mg}$ and $\mathrm{Bi}$
e) Effects of $\mathrm{Mg}$ and Bi Additions on Sr Recovery to Dross and Powder
f) Influence of $\mathrm{Mg}$ and $\mathrm{Bi}$ on the Strontium Recovery from $\mathrm{SrCO}_{3}$
g) Strontium, Magnesium and Bismuth Distribution to Reaction Products
h) XRD Results
i) Kinetics of the Reduction Process
j) Vacuum Distillation of Strontium from Aluminum
k) Thermodynamic Simulation vs. Experimental Results

Discussion of some of the possible physical and/or chemical phenomena involved is also presented. 


\section{VIII.1.2 DISCUSSION OF THE EXPERIMENTAL PROGRAM AS PERFORMED}

The experimental program aimed to determine the extent of strontium extraction from $\mathrm{SrCO}_{3}$ by contacting the $\mathrm{SrCO}_{3}$ with molten aluminum. The program also aimed to determine the effect of $\mathrm{Mg}$ and $\mathrm{Bi}$ additions on the extent of strontium extraction. The experimental results were found to agree with those predicted. However, $\mathrm{Mg}: \mathrm{Sr}$ molar ratios greater than those used were predicted to yield greater strontium extraction. Therefore experiments with higher $\mathrm{Mg}: \mathrm{Sr}$ molar ratios would have been useful. In the case of bismuth addition, the experimental results were similar to those predicted thermodynamically and there was no suggestion that higher extractions were possible.

\section{VIII.1.3 DISCUSSION OF THE EXPERIMENTAL PROCEDURE}

The experimental procedures employed are directly and indirectly responsible for various side effects such as a) Oxygen Contamination, b) Temperature Fluctuation, c) Metal loss by Vaporization and d) Heterogeneous Mixing. The reactor design was the major factor of concern to minimize these side effects. A reactor design which permited heating the impeller and the molten bath simultaneously would minimize air contamination and temperature fluctuation during introduction of the mixing device. A better design could also provide better condenser and seals to prevent the escape of metal vapour. Poor mixing created a dead zone of unreacted material in the upper part of the crucible (Figure 47). Better mixing would certainiy improve strontium recovery for the same conditions of temperature (1273 K) and pressure (1 atm). 


\section{VIII.2 COMPARISON OF INGOT ASSAYS}

The chemical assays of the metal ingot were compared with an outside laboratory. The ingot samples analyzed by Metriclab Inc.' and at McGill University are shown in Table XXXVIII.

Table XXXVIII Comparison of assay results

\begin{tabular}{|c|c|c|c|c|c|c|}
\hline & \multicolumn{3}{|c|}{ STRONTIUM (Wt\%) } & \multicolumn{3}{c|}{ MAGNESIUM (Wt\%) } \\
\hline Exp. \# & McGill & METRIC. & Diff. (\%) & McGill & METRIC. & Diff. (\%) \\
\hline 1 & 0.53 & 0.16 & 69.8 & 1.24 & 1.34 & -8.1 \\
\hline 2 & 0.93 & 0.77 & 17.2 & 2.79 & 2.38 & 14.7 \\
\hline 3 & 1.09 & 0.97 & 11.0 & 4.46 & 4.12 & 7.6 \\
\hline 4 & 1.26 & 1.14 & 9.5 & 5.33 & 5.30 & 0.6 \\
\hline 5 & 1.97 & 2.5 & -26.9 & 7.49 & 6.34 & 15.3 \\
\hline
\end{tabular}

It can be seen that the results are similar. The average difference for strontium and magnesium assays are $16.1 \%$ and $6 \%$ respectively. Experiment 1 shows a big difference between results from McGill and Metriclab (69.8\%). Considering Experiment 2 to 5, the average difference for the strontium assays would be $2.7 \%$. Nevertheless the average results (Experiment 1 to 5) are acceptable taking into account the segregation in samples and between samples and also the difference between laboratory performances.

1 METRICLAB (1980) Inc. Ste-Marthe-du-Lac, Qc (514) 473-0902 


\section{VIII.3 MASS BALANCES}

Mass balances were performed for strontium, magnesium and bismuth. The total masses of $\mathrm{Sr}, \mathrm{Mg}$ and $\mathrm{Bi}$ contained in the reaction products were determined by multiplying their respective assays by the masses of each reaction product. The masses of $\mathrm{Sr}, \mathrm{Mg}$ and $\mathrm{Bi}$ contained in the reaction products were compared with the masses contained in the reactants. The difference between the mass for a specific element present in the reactant and the mass in the reaction products is indicated as a percentage of the amount in the reactant. The mass of individual element contained in the reactants (Mass In) and in the products (Mass Out) is shown in Tables XXXIX to XLI. The initial mass of strontium was obtained by multiplying the mass of $\mathrm{SrCO}_{3}$ by the strontium mass fraction, $\mathrm{X}_{\mathrm{Sr}}$, in $\mathrm{SrCO}_{3}$ (e.g., $\mathrm{SrCO}_{3}: \mathrm{X}_{\mathrm{Sr}}=87.62 / 147.62$ ).

Table XXXIX Mass Balance for Strontium

\begin{tabular}{||c|c|c|c|}
\hline Experiment \# & Mass In (g) & Mass Out (g) & Difference (\%) \\
\hline 0 & 29.68 & 27.32 & -7.95 \\
1 & 29.68 & 31.18 & 5.05 \\
2 & 29.68 & 32.38 & 9.08 \\
3 & 29.68 & 30.48 & 2.68 \\
4 & 29.68 & 32.10 & 8.15 \\
5 & 29.68 & 31.90 & 7.48 \\
6 & 29.68 & 27.20 & -8.35 \\
7 & 29.68 & 25.38 & -14.49 \\
8 & 29.68 & 24.64 & -17.0 \\
\hline
\end{tabular}


The mass balance for strontium indicates an average difference of $1.79 \%$ between the strontium contained in the reactants and that contained in the products. The low average difference is because of the large gap between the positive (Experiment 1 to 5) and the negative values (Experiment 6 to 8). However, the largest difference was obtained in Experiment 8 and reached the value of $17 \%$ which was acceptable considering the segregation in samples and between samples. The sources of strontium discrepancy include analytical error and material loss through the off-gas. The strontium difference appears to be positive for Experiments 1 to 5 containing magnesium. As mentioned in Section VI.3, magnesium is known to have positive matrix effect ${ }^{(41)}$ on the strontium absorbance during chemical assaying and may have positively influenced the assay results. The strontium difference for Experiment 6 to 8 is negative and increasing with the bismuth addition. The bismuth precipitate observed in the assay solutions (milky appearance) could have negatively influenced the strontium assay. The strontium loss could also be related to mass diffusion through the crucible and the impeller material.

Table XL Mass Balance for Magnesium

\begin{tabular}{|c|c|c|c|}
\hline Experiment \# & Mass In $(\mathrm{g})$ & Mass Out $(\mathrm{g})$ & Difference (\%) \\
\hline 0 & - & - & - \\
1 & 16.53 & 16.28 & -1.49 \\
2 & 32.86 & 29.94 & -8.89 \\
3 & 49.39 & 43.19 & -12.55 \\
4 & 65.98 & 54.27 & -17.74 \\
5 & 82.37 & 71.51 & -13.19 \\
6 & - & - & - \\
7 & - & - & - \\
8 & - & - & - \\
\hline
\end{tabular}


The strontium diffusion could have been possible due to the concentration gradient and low surface tension of the molten alloy. The mass balance for magnesium indicates an average difference of $-10.8 \%$. It can be seen that the magnesium loss increased with the increasing amount of magnesium added as reactant. A certain amount of magnesium have been loss through the white off-gas. Part of this vapour was recuperated as condensate. However, a significant amount could have escaped through the impeller shaft hole and the utility hole. The off-gas was driven out of the crucible by the positive pressure created inside the crucible by the argon flushing. Analytical error could have been the other source of error contributing to magnesium losses.

Table XLI Mass Balance for Bismuth

\begin{tabular}{|c|c|c|c|}
\hline \hline Experiment \# & Mass In (g) & Mass Out (g) & Difference (\%) \\
\hline 0 & - & - & - \\
1 & - & - & - \\
2 & - & - & - \\
3 & - & - & - \\
4 & - & - & - \\
5 & - & 8.18 & -10.76 \\
6 & 9.17 & 23.80 & -14.12 \\
7 & 27.72 & 48.05 & -13.23 \\
8 & 55.38 & - \\
\hline
\end{tabular}

The mass balance for bismuth indicates an average difference of $-12.7 \%$. Small quantities of bismuth vaporized and condensed on the crucible cap (condenser). However, a certain amount of off-gas containing bismuth escaped which contributed to bismuth loss. Another source of bismuth loss was attributed to the assays where a white precipitate formed in the solution to be 
analyzed. The solution contained more precipitate as the bismuth addition to the melt was increased. 


\section{VII.4 THE EFFECT OF METAL SOLUTE ADDITIONS ON THE DROSS AND POWDER PRODUCT ASSAYS}

This section is concerned on the strontium content of the dross and powder residue as a function of the magnesium and bismuth additions. The magnesium and the bismuth content of the ingots is also discussed. The effects of $\mathrm{Mg}$ and $\mathrm{Bi}$ on the strontium recovery to the ingot are presented in the next section.

\section{VIII.4.1 Effect of Magnesium Addition}

The effect of magnesium additions on the strontium content of the powder residue and dross is shown in Figure 39. The strontium concentration in the powder residue increases from $40.8 \%$ to $50.8 \%$ (Mg:Sr molar ratio range of 0 to 6 ) then decreases from $6 \mathrm{Mg}: \mathrm{Sr}$ to $10 \mathrm{Mg}: \mathrm{Sr}$ molar ratio. The strontium concentration in the powder residue at $10 \mathrm{Mg}: \mathrm{Sr}$ is $33.3 \%$.

It can also be seen in Figure 39 that the strontium concentration in the dross stayed almost constant over the experiments with or without magnesium or bismuth addition. The concentration ranged from $5.2 \%$ when no magnesium was present to $7.4 \%$ at a $\mathrm{Mg}: \mathrm{Sr}$ molar ratio of $10: 1$. The small increase in strontium content of the dross could have been due to the lower surface tension of the melt with increasing magnesium addition. As magnesium content in the melt increased, the surface tension of the meit was lowered which improved solid/liquid contact. Solids could have been trapped in liquid aluminum rendering it more viscous. The viscous aluminum rested on top of the melt which became part of the dross product. The increase in strontium content 
in the dross at $10 \mathrm{Mg}: \mathrm{Sr}$ could have possibly been the result of larger amount of strontium compounds trapped in the dross product.

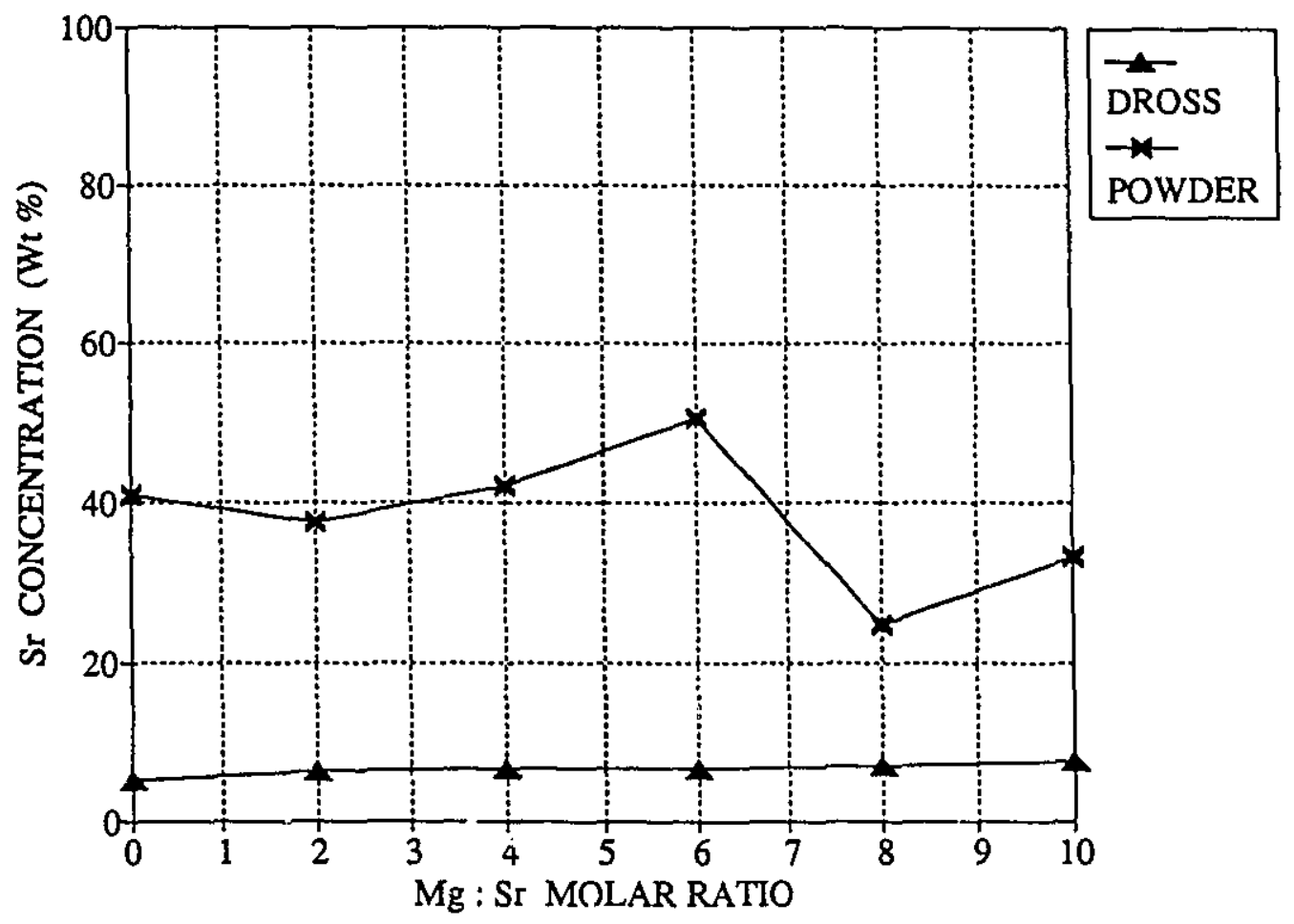

Figure 39 Strontium Concentration in Dross and Powder (Mg Addition)

Figure 40 shows the increase in strontium concentration in dross with bismuth addition. Bismuth addition also lowered the surface tension of the melt. The equivalent surface tensions of the melt with magnesium or bismuth addition were given in Table IX. The strontium content of the dross, varied from $5.3 \%$ to $12.4 \%$ with the addition of 1 to 6 wt $\%$ bismuth respectively. In the powder residue, the strontium content increased from 21.7 to $37.9 \%$ as bismuth increased from 1 to $6 \mathrm{wt} \%$.

The magnesium concentration in the reaction products, Figure 41 , increased steadily with the increase in the Mg:Sr molar ratio. The increase in ragnesium concentration was to be expected since magnesium was added increasingly to the system. However, the concentrations 


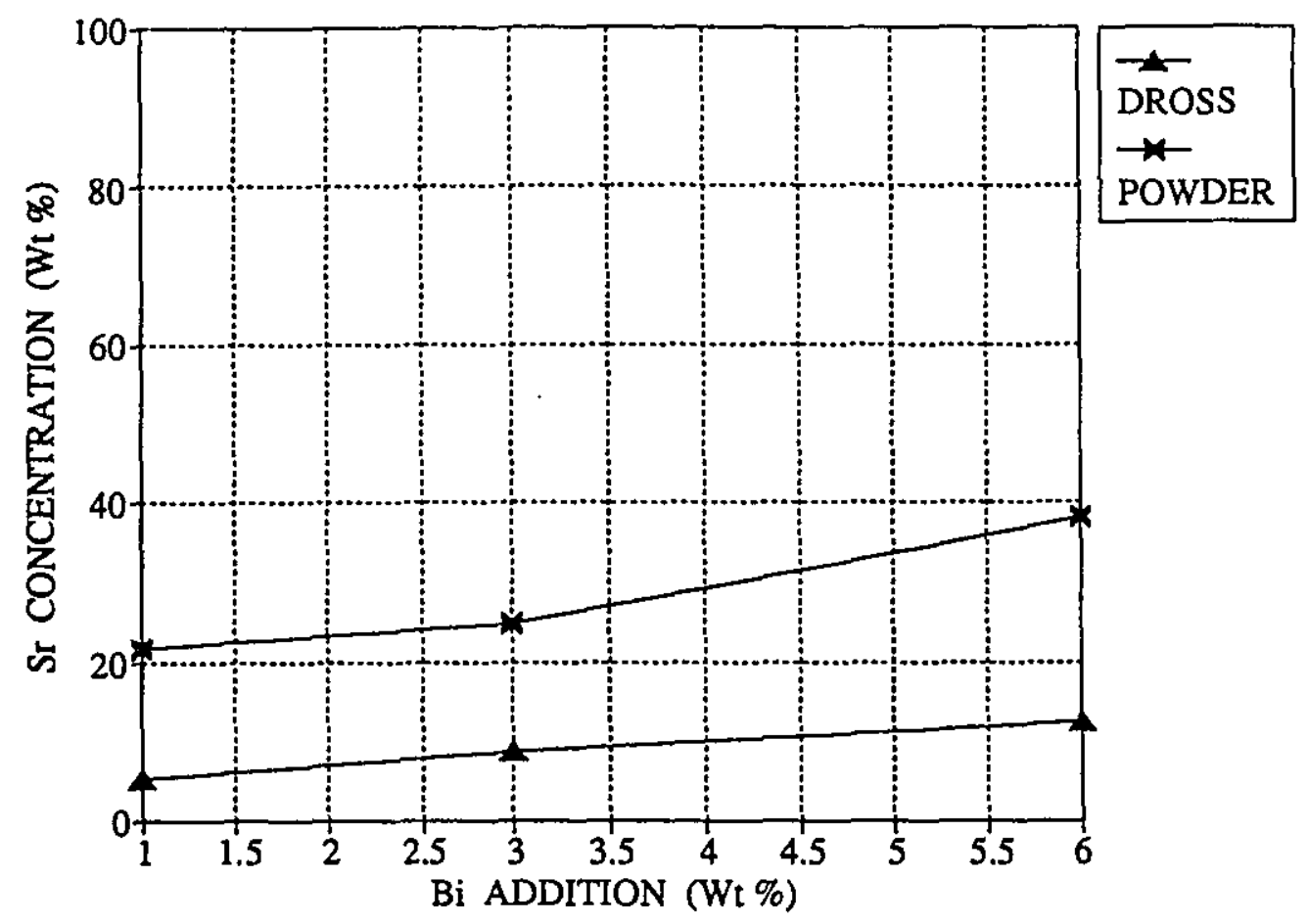

Figure 40 Strontium Concentration in Dross and Powder (Bi Addition)

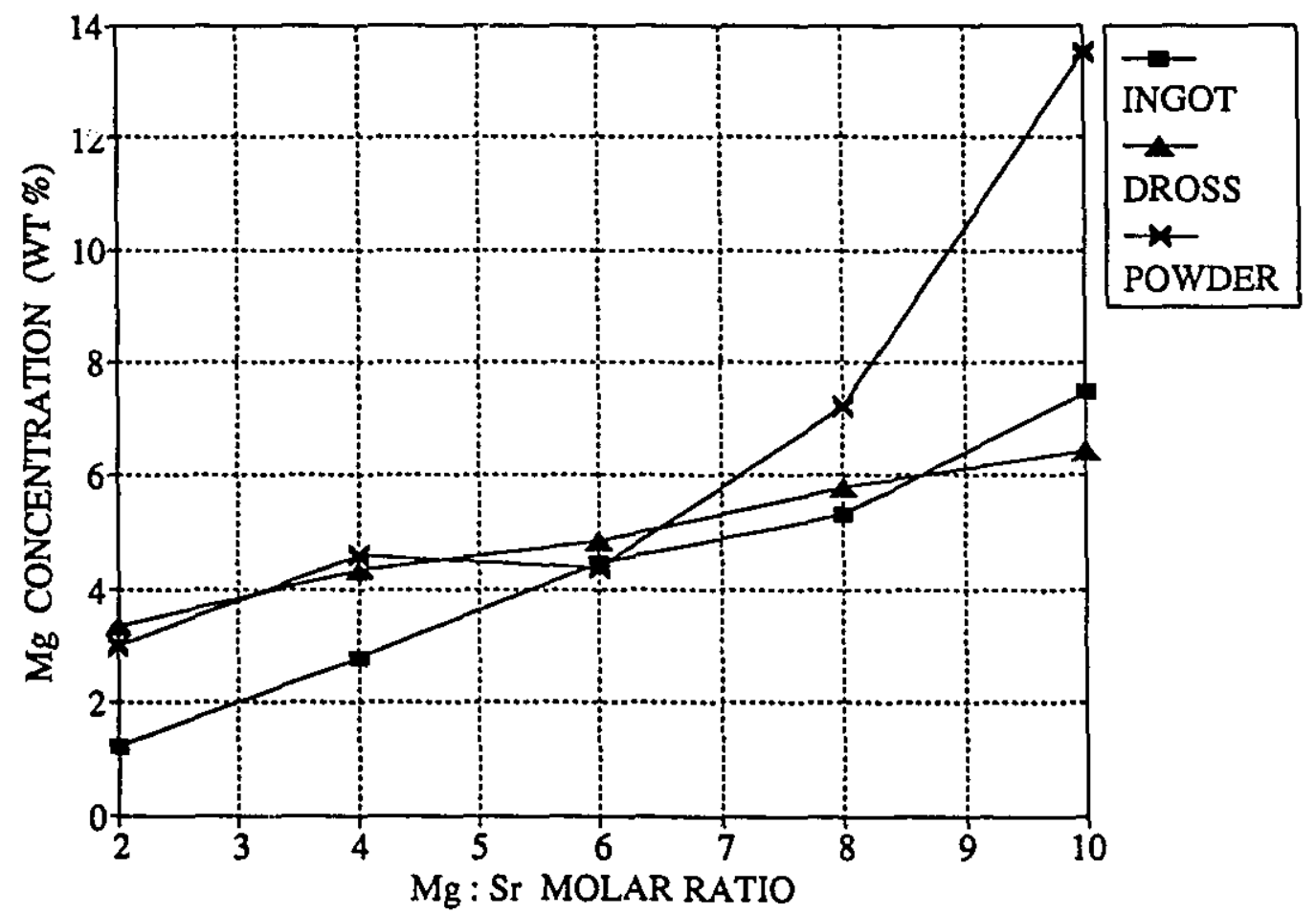

Figure 41 Magnesium Concentration in Reaction Products 
of magnesium were less than the weight percent which was theoretically expected according to the stoichiometric amounts of the reactants. It can also be observed that the magnesium concentration in the dross and powder are almost similar and increased as more magnesium was added to the system. Since the condensate was almost entirely magnesium in the form of $\mathrm{MgO}$, a considerable amount of magnesium could have been lossed through evaporation. Other losses were attributed to oxidation and reaction from the alloy.

Figure $4 \hat{z}$, shows that bismuth concentrations increased for the ingot and the powder residue while it remained almost constant in the dross. As for magnesium, the bismuth concentrations were less than the stoichiometric amounts of the reactants. Bismuth was found in the condensate in the form of oxide which implied a loss by evaporation. Other forms of losses included oxidation and other side reactions.

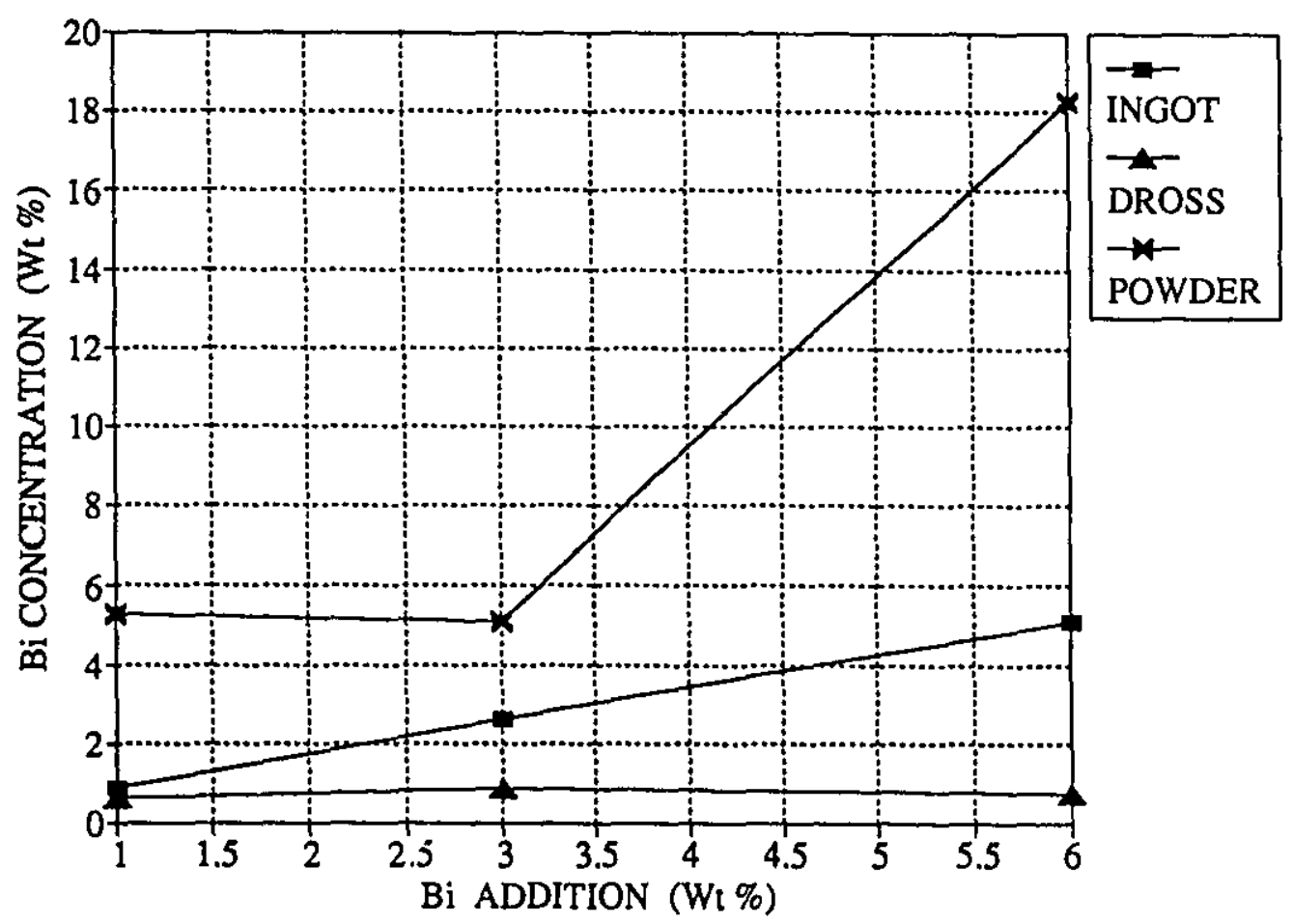

Figure 42 Bismuth Concentration in Reaction Products 


\section{VIII.5 STRONTIUM RECOVERY FROM $\mathrm{SrCO}_{3}$ VS. $\mathrm{Mg}$ and Bi ADDITION}

Figure 43 shows the strontium recovery to the metal ingot with magnesium additions. The strontium recovery was determined by the following equation.

$$
\text { Sr Rec. (\%) }=\frac{\text { Mass of Strontium in Ingot }}{\text { Mass of Strontium Charged }} \times 100
$$

The mass of strontium was obtained by multiplying the wt\% of strontium in the ingot by the ingot mass. The mass of strontium charged represented the strontium contained initially in the starting material, $\mathrm{SrCO}_{3}$. It can be observed that the strontium recovery increased with the $\mathrm{Mg}: \mathrm{Sr}$ molar ratio. It reaches a maximum of $51.3 \%$ for a $\mathrm{Mg}: \mathrm{Sr}$ molar ratio of $10: 1$. Figure 44 shows the strontium recovery to the metal ingot where the additive metal was bismuth. It can be observed that the strontium recovery was improved for one wt\% bismuth addition. However, the strontium recovery stays almost unchanged up to $6 \mathrm{wt} \%$ bismuth addition. Generally, the strontium recovery was not improved significantly with bismuth addition over the renge one to six weight percent. However, strontium recovery was greatly improved by increasing the $\mathrm{Mg}: \mathrm{Sr}$ molar ratio and could be explained by the following:
a) Lower melt surface tension
b) Higher oxygen affinity of the melt
c) Lower activity coefficient of strontium
d) Lower activity of $\mathrm{Al}_{2} \mathrm{O}_{3}$ in the reaction products due to spinel formation. 


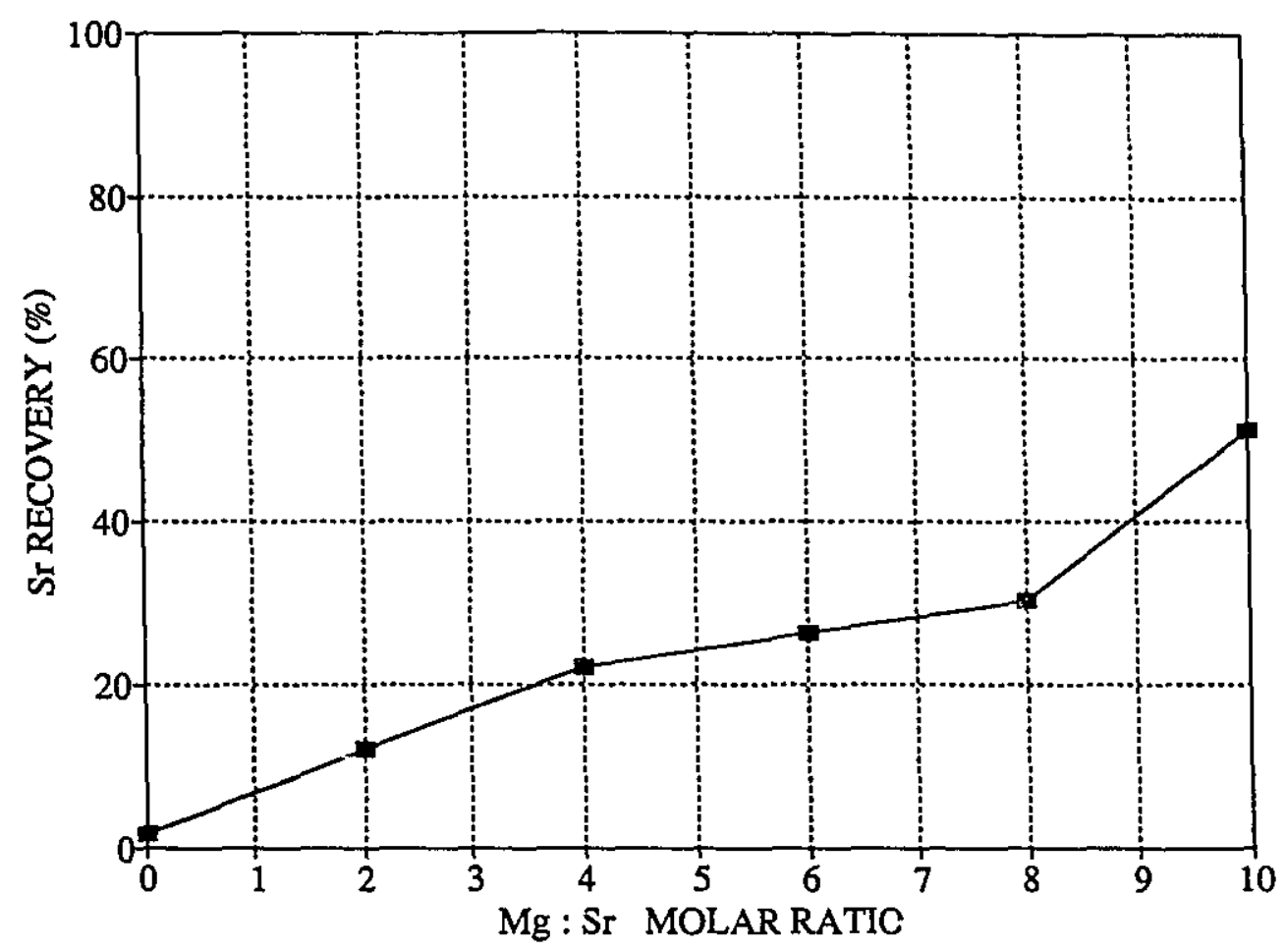

Figure 43 Strontium Recovery vs. Mg:Sr Molar Ratio

By increasing the amount of magnesium (solute metal), the surface tension of the melt (solvent metal) was lowered significantly, Figure 8 , and it can be summised that the lower surface tension favoured wetting and so improved the solid/liquid contact and enhanced reactions taking place at the interface and increased the amount of strontium dissolved into the excess molten reductant. However, Figure 44 shows that no significant improvement in strontium recovery was obtained for a bismuth addition above one wt\%. Table IX showed that a lower melt surface tension was obtained with bismuth content of $6 \mathrm{wt} \%$ than with a $\mathrm{Mg}: \mathrm{Sr}$ molar ratio of 10:1. Therefore, the surface tension was not the only factor responsible for the improvement in strontium recovery with magnesium addition.

The magnesium dissolved in the melt had a greater affinity for oxygen than aluminum while the oxygen affinity for bismuth was very low according to the following reactions ${ }^{(34)}$. 


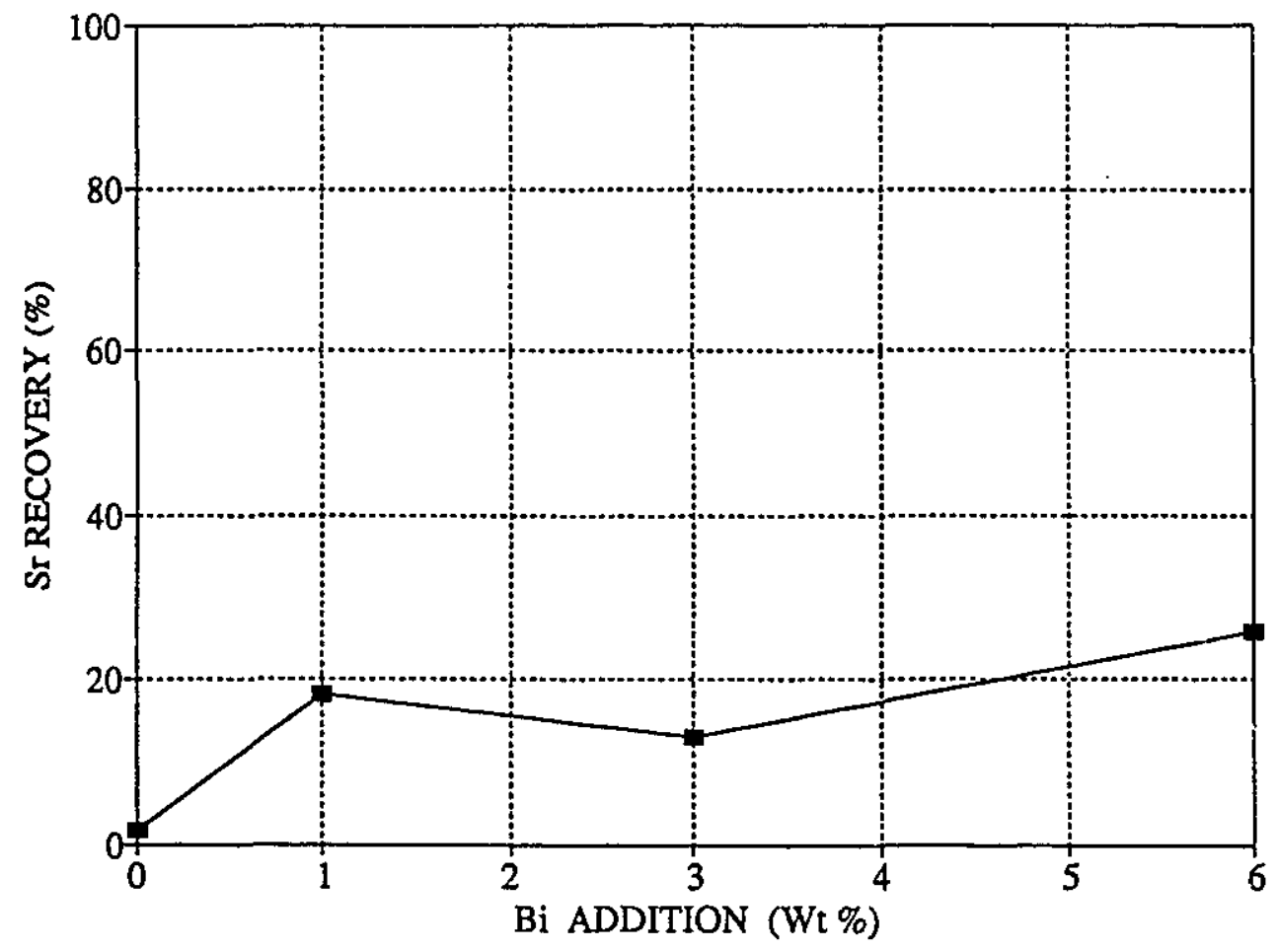

Figure 44 Strontium Recovery with Bismuth Addition

$$
\begin{array}{ll}
2 \mathrm{Mg}+\mathrm{O}_{2}=2 \mathrm{MgO} & \Delta G=-923 \mathrm{~kJ} @ 1000{ }^{\circ} \mathrm{C} \\
\frac{4}{3} \mathrm{Al}+\mathrm{O}_{2}=\frac{2}{3} \mathrm{Al}_{2} \mathrm{O}_{3} & \Delta G=-847 \mathrm{~kJ} @ 100{ }^{\circ} \mathrm{C} \\
\frac{4}{3} \mathrm{Bi}+\mathrm{O}_{2}=\frac{2}{3} \mathrm{Bi}_{2} \mathrm{O}_{3} & \Delta G=-161 \mathrm{~kJ} @ 1000^{\circ} \mathrm{C}
\end{array}
$$

Therefore, the reaction mechanism with magnesium in the melt might involve the reduction of the impervious aluminum oxide film (Figure 9) which would accelerate the wetting of the strontium oxide. Although bismuth lowereci the surface tension of the melt, it would not reduce the aluminum oxide film present in the system. In addition, a larger amount of aluminum oxide is more likely to be present in the melt toward the end of an experiment than at the 
beginning due to oxygen contamination. This could explain the increase in strontium recovery, promoted by the addition of bismuth which resulted in a lower surface tension, at the beginning of the experiment. But after the first twenty minutes, the reaction rate diminished to a plateau value due to the aluminum oxide film on the liquid surface, impossible to be reduced by bismuth, preventing further reaction to take place.

Magnesium could have also reduced some strontium compounds present in the system which contributed to the final strontium recovery at $10 \mathrm{Mg}: \mathrm{Sr}$ molar ratio.

Another consideration was the activity of strontium which was lowered by the excess of aluminum reductant (dilution effect) and the presence of a solute metal (interaction effect). The dilution effect would be simple to verify e.g., change the amount of excess $\mathrm{Al}$, but it would be more difficult to verify the interaction effect since no data are available for the following interaction coefficients, $\varepsilon_{s r}^{M g}$ or $\varepsilon_{s r}^{B 1}$, with aluminum as the solvent. The Strontium-Aluminum system $^{(54)(55)(57)}$ was found to show large deviations from ideality which suggested a considerable stability of the intermetallic compour.ủs formed in solid and liquid state. Experimental evidence $^{(57)}$ shows that the Al-Sr system exhibits negative deviations from ideality which imply that $\gamma_{S r}^{A 1} \ll 1$. The following basic equation for aluminothermic reduction presents briefly the role of the activity coefficient on the overall reaction Gibbs free energy.

$$
\begin{gathered}
3 S r O+2 A l-3 S r+A_{2} O_{3} \\
\Delta G=\Delta G^{0}+R T \ln \frac{a_{S r}^{3}}{a_{A l}^{2}}
\end{gathered}
$$


According to thermodynamic definitions for the activity, and considering that $\mathrm{Al}$ may behave ideally, $\gamma_{\mathrm{Al}} \approx 1$, at equilibrium the Equation 41 may be rewritten,

$$
\Delta G^{0}--R T \ln \frac{\gamma_{s r}^{3}[S r]^{3}}{[A l]^{2}}
$$

Here, the activity of the aluminum is approximately equal to its concentration. Thus, an increase of the strontium activity coefficient, $\gamma_{S r}$, would offset the reaction to the right ( $\Delta \mathrm{G}$ becoming more positive). Furthermore, the addition of a solute metal such as magnesium or bismuth would affect the equilibrium by changing the activity coefficient of Sr. A knowledge on the interaction parameter values would give further information on the behaviour of the strontium activity coefficient in presence of solute metals. A positive value for $\varepsilon_{s r}^{\mathrm{Mg}}$ implies an increase in $\gamma_{S \mathrm{r}}$ which would not be favourable, while a negative value for $\varepsilon_{S r}^{\mathrm{Mg}}$ implies a decrease in $\gamma_{\mathrm{sr}}$ which would be favourable for the reaction.

\section{VIII.5.1 Distribution to Reaction Products}

The mass balances for strontium, magnesium and bismuth are presented as: percentage distributed to the various reaction products. Figures 45 to 47 show respectively, the distribution of strontium, magnesium and bismuth in the reaction products for each experiment. The figures present a visual approach which facilitates comparison and relationship between reaction products described in the previous section.

Figure 45 shows that the percentage of strontium present in the ingot increased as the 
$\mathrm{Mg}: \mathrm{Sr}$ molar ratio was increased (Experiments 0 to 5). It can also be observed that the percentage of strontium with bismuth addition (Experiments 6 to 8) slightly increases to reach a plateau value around $20 \% \mathrm{Sr}$ extraction. The distribution of strontium to the dross is similar for all experiments. However, the percentage of strontium reporting to the dross diminishes as the magnesium to strontium molar ratio was increased. Experiments with bismuth addition also showed a tendency for the strontium percentage reporting to the dross to decrease with increasing the bismuth content of the melt. The distribution plots show that the strontium content of the ingot increased with a decrease in the theoretical strontium content of the powder while the strontium content of the dross demonstrated no such dependence. There was no evidence of strontium in the condensate phase although it has been specified in the legend to Figure 44.

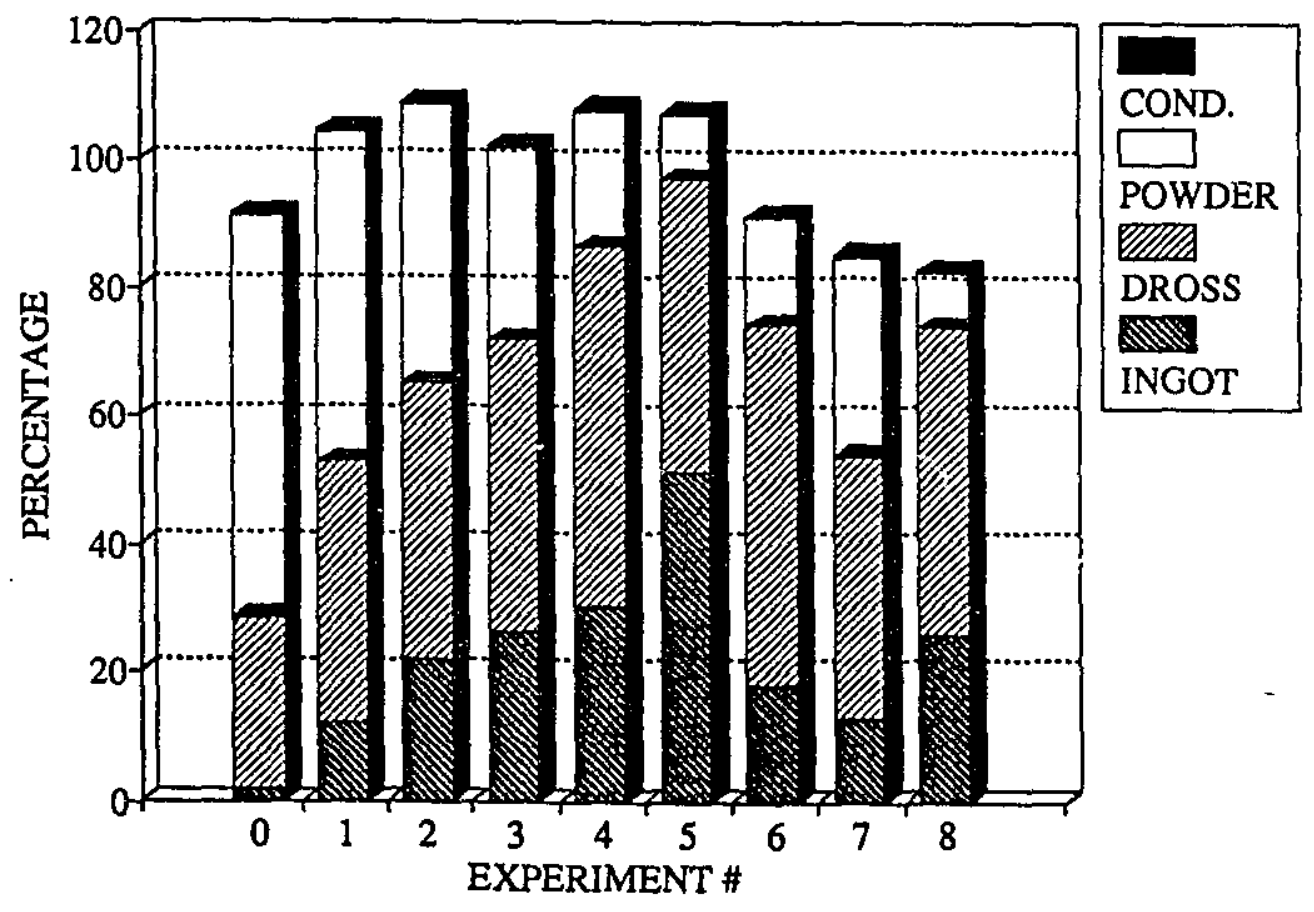

Figure 45 Strontium Distribution to Reaction Products 
The magnesium distribution to reaction products, Figure 46, indicates that the percentage of magnesium in the ingot increased as the $\mathrm{Mg}: \mathrm{Sr}$ molar ratio was increased. Conversely, the percentage of magnesium contained in the dross and powder decreased with increasing the $\mathrm{Mg}: \mathrm{Sr}$ molar ratio. The amount of magnesium contained in the condensate was almost constant. It can be seen that the magnesium content diminished from Experiments 1 to 5 . This meant that adding more magnesium promoted reactions which resulted in a larger amount of strontium to be recovered as $\mathrm{Mg}: \mathrm{Sr}$ molar ratio was increased. Losses of material were imputed to oxidation, vaporization and side reactions within the system (e.g., Spinel formation, $\mathrm{MgO} \cdot \mathrm{Al}_{2} \mathrm{O}_{3}$ ).

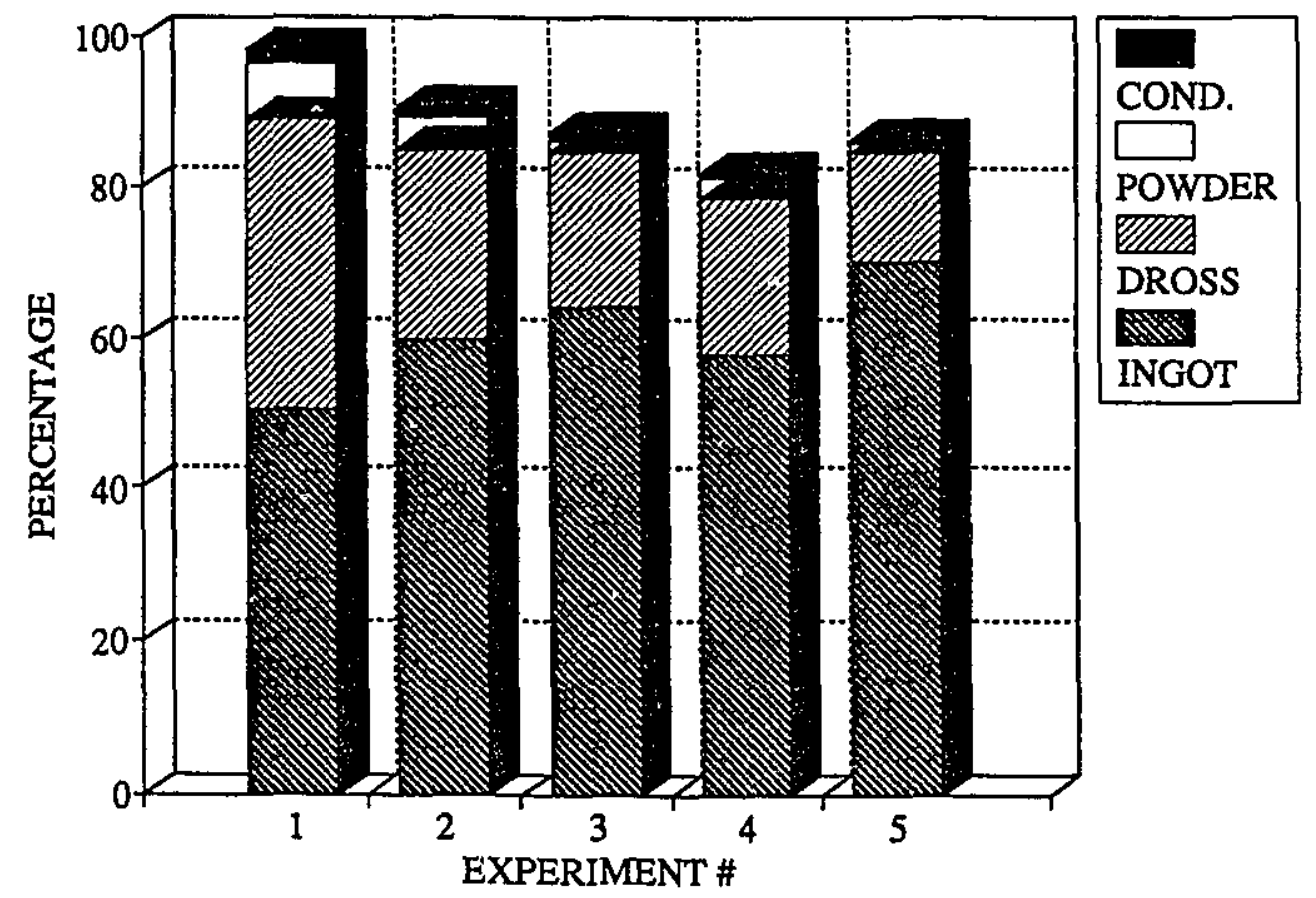

Figure 46 Magnesium Distribution to Reaction Products

The bismuth distribution to reaction products, Figure 47, shows an increase in bismuth content of the ingots with increasing $\mathrm{Bi}$ additions. However, the percentage of bismuth in the 
dross and powder diminished. The percentage of bismuth in the condensate was very small due to the small quantity of condensate recuperated on the condenser. Losses of bismuth were imputed to the oxidation and vaporization.

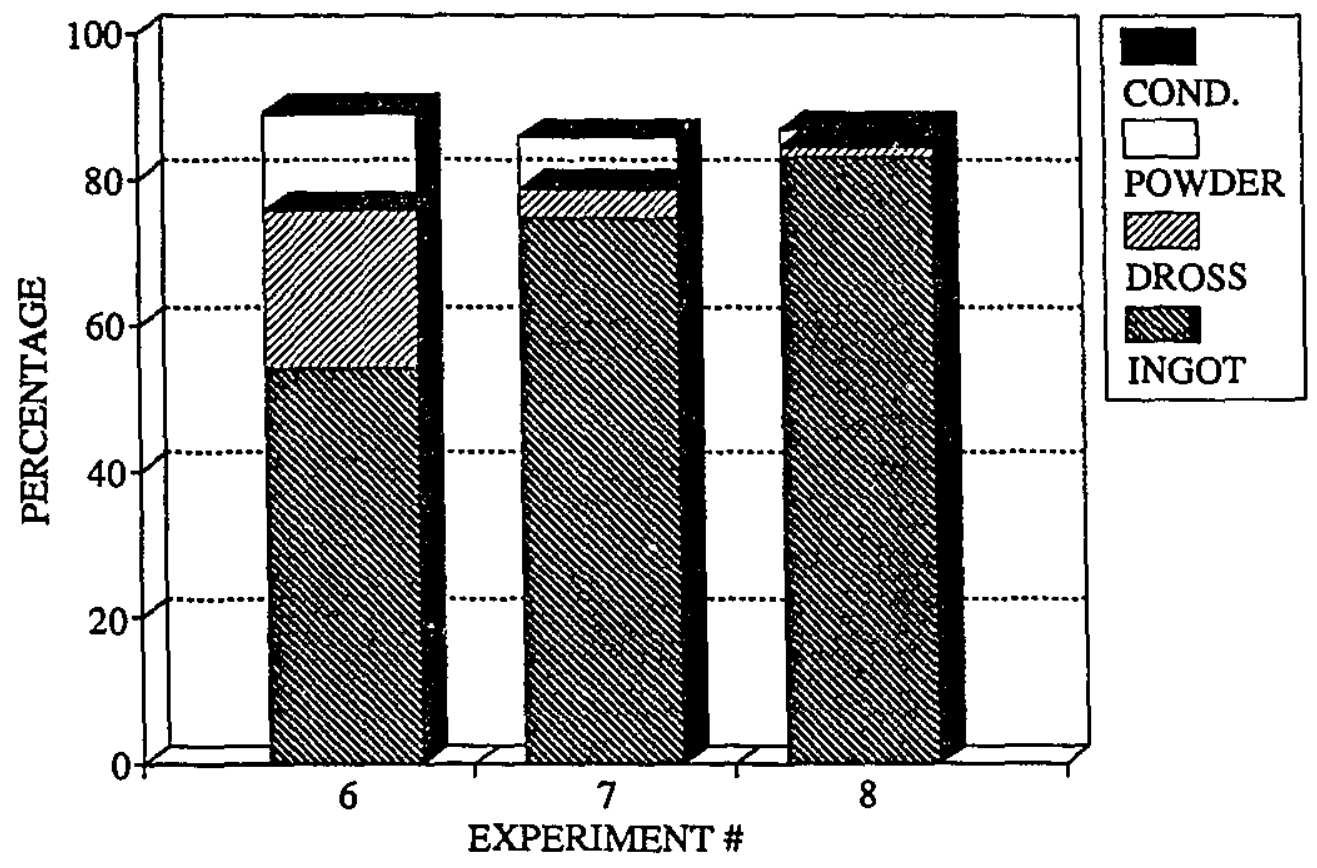

Figure 47 Bismuth Distribution to Reaction Products 


\section{VIII.6 DISCUSSION OF XRD RESULTS}

As mentioned in Section VI.2, the powder residue was composed of a variety of compounds. The nature of the compounds formed gave an indication about the physical and/or chemical mechanisms involved in the reduction process.

The species identified in the powder residue were; Strontium Carbonate, Aluminum, Corundum, Aluminum Carbide, Spinel, Strontium Oxide, Periclase and Bismuth Oxide. The strontium carbonate was the starting material which has been consequently found in the powder residue. The reason strontium carbonate did not completely dissociate to give strontium oxide and carbon dioxide could be the result of poor mixing. The mixing was provided by an impeller which pushed the solids toward the crucible wall. At the end of an experiment, a bed of solid including unreacted $\mathrm{SrCO}_{3}$ was packed on the crucible wall, Figure 48. This $\mathrm{SrCO}_{3}$ clearly did not dissociate and react with the molten reductant.

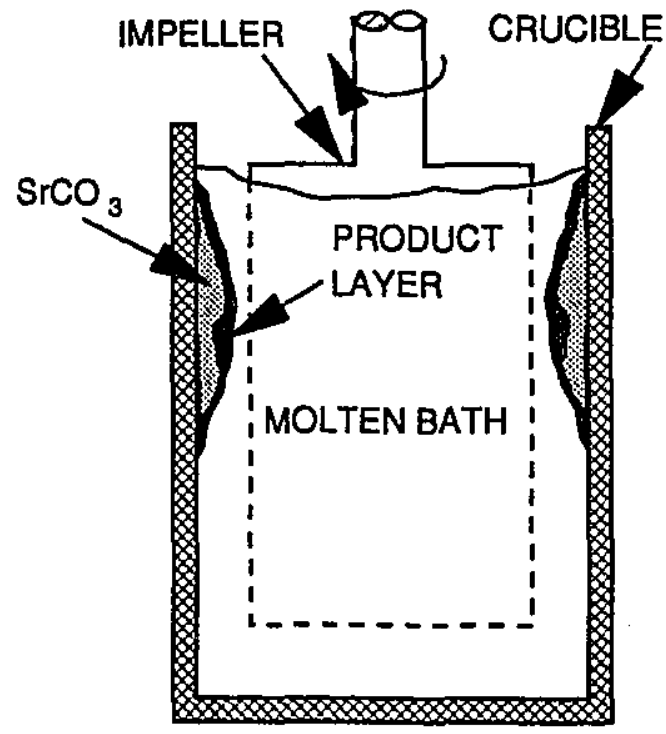

Figure 48 Schematic Representation Stagnant Zone of $\mathrm{SrCO}_{3}$ 
Aluminum was also entrained in the powder residue as droplets or nodules which were found on the dross surface. The oxygen present in the system induced the formation of aluminum oxide, magnesium oxide and bismuth oxide. The magnesium oxide and the aluminum oxide have resulted in synthetic spinel formation, $\mathrm{MgO} \cdot \mathrm{Al}_{2} \mathrm{O}_{3}$. Aluminum Carbide could have been produced by a reaction involving carbon from $\mathrm{SrCO}_{3}$ dissociation or from the carbon steel shaft of the impeller.

Strontium Oxide was the dissociation product of the carbonate. Some SrO could have been trapped in the stagnant zone which was not reduced. Moreover, the SrO could have been the result of oxidation prior to dissolution into the molten reductant and it could also be possible that it was also the product of the reduction of alumina by strontium metal in the system.

The condensates with magnesium and bismuth addition contained mainly synthetic periclase, $\mathrm{MgO}$ and bismuth oxide, $\mathrm{Bi}_{2} \mathrm{O}_{3}$, respectively. These oxides formed via vapourization of the mevilic element from the molten bath and subsequent oxidation. 


\section{VIII.7 KINETICS OF STRONTIUM REDUCTION}

The kinetics of the reactions were determined by plotting the strontium recovery in the kinetic samples versus the time at which they were withdrawn from the melt. The strontium recovery to the kinetic samples was determined by the following equation:

$$
\text { REC. of } S r \text { in KIN. (\%) }=\frac{K I N \cdot{ }_{S r}}{\left(\text { Mass }_{S r} / \text { Mass }_{m}\right)} \times 100
$$

where $\mathrm{KIN}_{\mathrm{Sr}}$ : Strontium contained in the kinetic sample

Mass $_{\mathrm{Sr}}$ : Initial mass of strontium from reactant

Mass $_{\mathrm{m}}$ : Mass of the melt

Figure 49 , indicates that the rates of strontium recovery to the melt with magnesium additions increased steadily with time for the Experiments 2 to 5 . It can also be observed that the rate of extraction increased with increasing the $\mathrm{Mg}$ :Sr molar ratio. Experiment 0 showed that the rate of extraction diminished with time. The extraction in Experiment 0 could have been constrained by the formation of an impervious aluminum oxide film already discussed in a previous section. For Experiment 1, it can be seen that the rate of extraction reached a plateau after 40 minutes. Magnesium depletion could be the cause for the reaction to stop around the $40^{\text {th }}$ minute for Experiments 0 and 1.

The Figure 50 shows that the rate of extraction did not increase significantly with bismuth additions. After 40 minutes, it can be seen that there is no or little increase in the rate of extraction. 


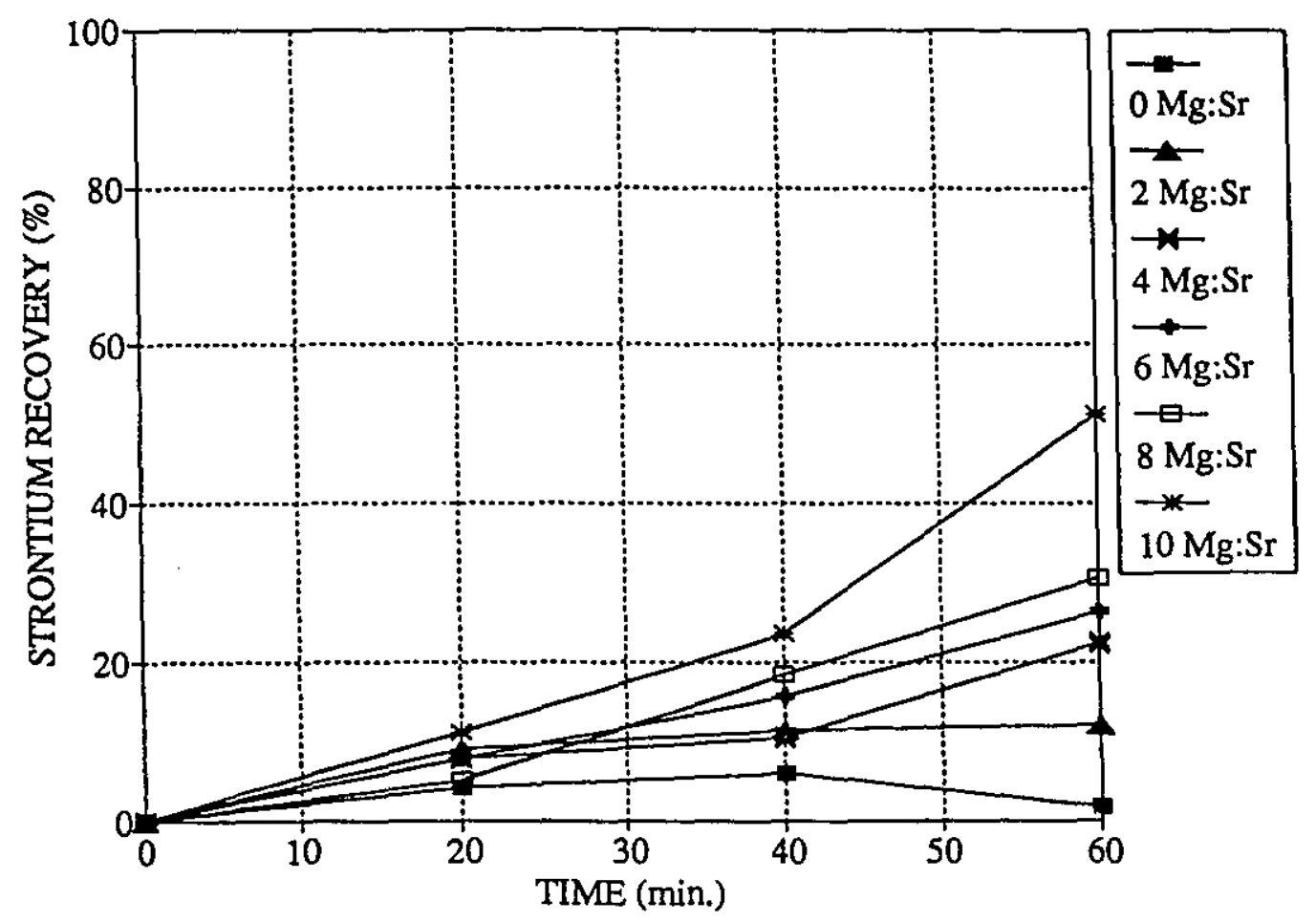

Figure 49 Strontium Recovery to the Melt as a function of Time and Mg Additions

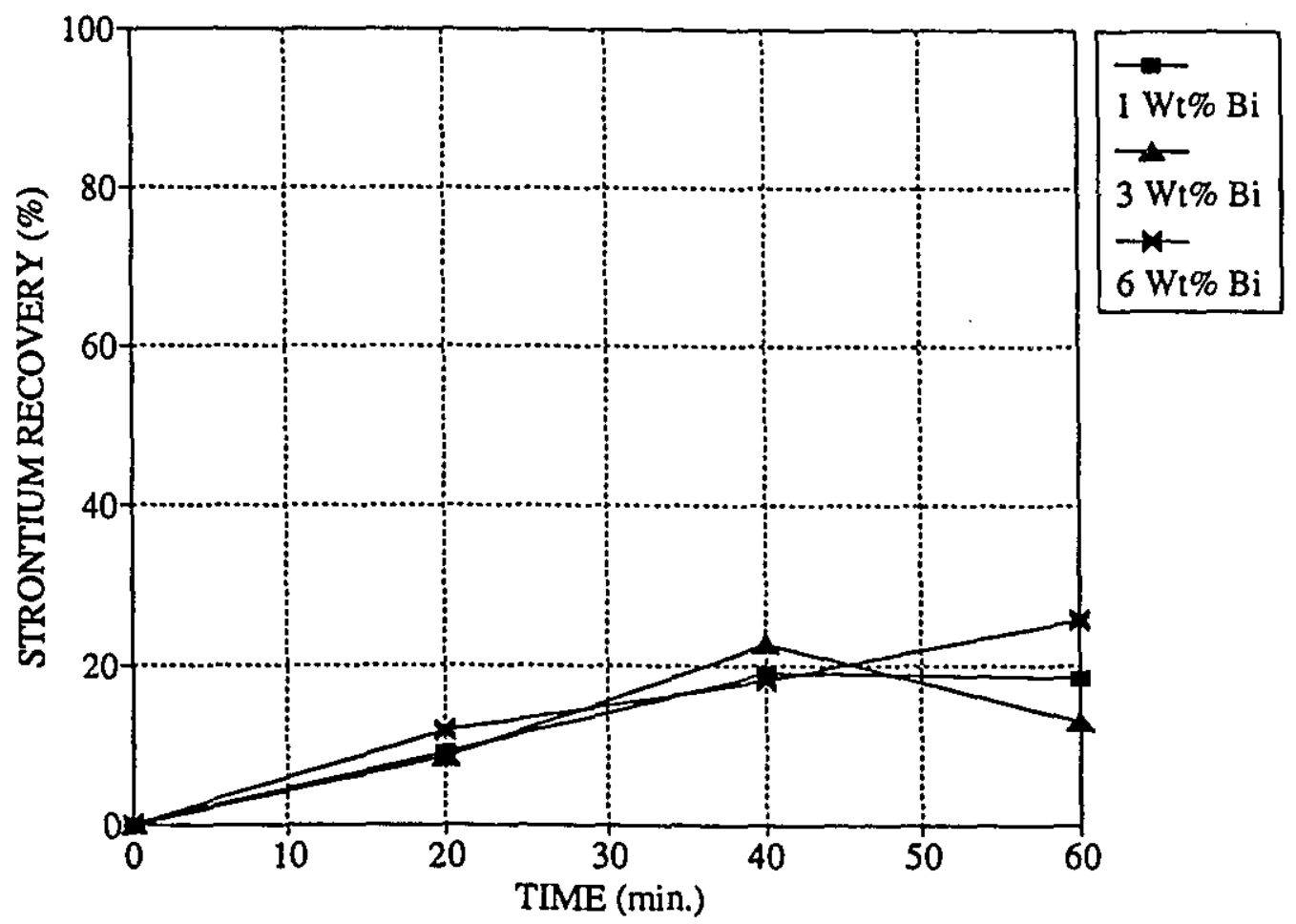

Figure 50 Stontium Recovery to the Melt as a function of Time and Bismuth Additions 
The determination of the factors which are responsible for the change in the strontium extraction rate is beyond the scope of this thesis. However, the decrease in the rate of extraction after 40 minutes could have been the result of the following:
a) Equilibrium of the system is reached
b) A rate limiting step has been reached
c) Depletion of strontium from the material source
d) Depietion of magnesium 


\section{VIII.8 VACUUM DISTILLATION OF STRONTIUM FROM ALUMINUM ALLOYS}

The MLE process involves recovery of the metal of interest firom the excess liquid metal reductant by vacuum distillation. In this thesis, the reduction step and dissolutinn step has been investigated. In practice the strontium would be recovered by vacuum distillation of the melted ingot. In this section, basic vicuum distillation principles are introduced as well as the theoretical approach to determine the feasibility of strontium distillation from aluminum.

In essence, the vacuum distillation technique is based on the difference in vapour pressure between the metals present in the melt. Metals more volatile than aluminum (the solvent metal) are removed by preferential evaporation when the melt is subjected to reduced pressures.

The theoretical background on vacuum distillation (vacuum refining) can be found in many publications (References 2 to 7 ). In general, the feasibility of removing a volatile solute, $i$, from a less volatile solvent, $b$, via vacuum distillation can be predicted by the volatility coefficient, $\Phi_{i}$, as defined by Olette ${ }^{(4)}$, Equation 44 .

$$
\Phi_{i}=\gamma_{i}^{o} \frac{P_{i}^{o}}{P_{i}^{o}}\left[\frac{M_{b}}{M_{i}}\right]^{1 / 2}
$$

where $\gamma_{i}^{0} \quad$ : Activity coefficient of solute $i$, in the melt

$P^{\circ} \quad$ : Equilibrium vapour pressure of pure species, $(\mathrm{Pa})$

$M \quad:$ Molecular mass, $(\mathrm{kg} / \mathrm{kgmole})$

$i, b \quad$ : Solute $\mathrm{i}$ and solvent $\mathrm{b}$, respectively 
In order for solute removal to occur via vacuum distillation, the value of the volatility coefficient of the solute must be greater than unity. The volatility coefficient, at different temperatures, of various solutes in molten aluminum are listed in Table XIII.

Table XIII shows that the volatility coefficient for strontium, magnesium and bismuth are all greater than unity at all specified temperatures. However, the literature ${ }^{(3)}$ indicates that if evaporation is rate-controlling, the values of the volatility coefficients for different species indicates the relative rates of removal of these solute metals from the aluminum melt. Therefore, the rate of removal for magnesium would be faster than strontium which suggests that a final product from fractional condensation could possibly be obtained with little $\mathrm{Mg}$ contamination. Details concerning the interaction between magnesium and strontium during vacuum distillation are not of concern in this work but information on the subject are available in Reference 56.

The vapour pressures of strontium over the intermetallics with aluminum $\left(\mathrm{Al}_{4} \mathrm{Sr}\right.$ and $\mathrm{Al}_{2} \mathrm{Sr}$ ) have been measured experimentally by Burylev et al. ${ }^{(57)}$ using the Knudsen's method. The temperature variation of the vapour pressure of strontium in the range $850-1100{ }^{\circ} \mathrm{C}$ was represented by the following equations:

$$
\begin{aligned}
& \log P(m m H g)=-\frac{12000}{T}+8.12 \\
& \log P(m m ~ H g)=-\frac{12000}{T}+9.36
\end{aligned}
$$


Table XLII Volatility Coefficient for Various Solute Metals, $\Phi_{1}$

\begin{tabular}{|c|llll|}
\hline & \multicolumn{4}{|c|}{ Volatility Coefficient, $\Phi_{\mathrm{i}}$} \\
\hline Solute, $\mathrm{i}$ & $\mathrm{T}=973 \mathrm{~K}$ & $\mathrm{~T}=1073 \mathrm{~K}$ & $\mathrm{~T}=1173 \mathrm{~K}$ & $\mathrm{~T}=1273 \mathrm{~K}$ \\
\hline $\mathrm{Li}$ & $8.89 \mathrm{E}+06$ & $2.03 \mathrm{E}+06$ & $5.96 \mathrm{E}+05$ & $2.12 \mathrm{E}+05$ \\
$\mathrm{Na}$ & $1.78 \mathrm{E}+12$ & $1.13 \mathrm{E}+11$ & $1.15 \mathrm{E}+10$ & $1.68 \mathrm{E}+09$ \\
$\mathrm{Be}$ & $2.45 \mathrm{E}+01$ & $1.82 \mathrm{E}+01$ & $1.43 \mathrm{E}+01$ & $1.17 \mathrm{E}+01$ \\
$\mathrm{Mg}$ & $3.43 \mathrm{E}+07$ & $5.51 \mathrm{E}+06$ & $1.21 \mathrm{E}+06$ & $3.34 \mathrm{E}+05$ \\
$\mathrm{Ca}$ & $7.94 \mathrm{E}+05$ & $1.69 \mathrm{E}+05$ & $4.69 \mathrm{E}+04$ & $1.58 \mathrm{E}+04$ \\
$\mathrm{Sr}$ & $2.21 \mathrm{E}+01$ & $1.33 \mathrm{E}+01$ & $8.73 \mathrm{E}+00$ & $6.10 \mathrm{E}+00$ \\
$\mathrm{Ba}$ & $7.23 \mathrm{E}-01$ & $5.05 \mathrm{E}-01$ & $3.79 \mathrm{E}-01$ & $2.99 \mathrm{E}-01$ \\
$\mathrm{Al}$ & $1.00 \mathrm{E}+00$ & $1.00 \mathrm{E}+00$ & $1.00 \mathrm{E}+00$ & $1.00 \mathrm{E}+00$ \\
$\mathrm{Si}$ & $4.42 \mathrm{E}-07$ & $1.40 \mathrm{E}-06$ & $3.67 \mathrm{E}-06$ & $8.29 \mathrm{E}-06$ \\
$\mathrm{Bi}$ & $3.02 \mathrm{E}+06$ & $6.10 \mathrm{E}+05$ & $1.61 \mathrm{E}+05$ & $5.25 \mathrm{E}+04$ \\
\hline
\end{tabular}




\section{VIII.9 DISCUSSION OF THE THERMODYNAMIC SIMULATION OF THE EXPERIMENTS}

The strontium recovery obtained in the experiments and that predicted by the thermodynamic simulations are presented in Figure 51 and 52 for $\mathrm{Mg}$ and $\mathrm{Bi}$ addition, respectively. The thermodynamic calculations ( $\mathrm{Mg}$ and $\mathrm{Bi}$ addition) were obtained on the basis of the following inputs to the EQULIB routine of the $\mathrm{F}^{*} \mathrm{~A}^{*} \mathrm{C}^{*} \mathrm{~T}$ thermodynamic database:

$$
\begin{aligned}
& \mathrm{SrCO}_{3}+100 \mathrm{Al}+\angle \mathrm{A}>\mathrm{Mg}= \\
& \mathrm{SrCO}_{3}+100 \mathrm{Al}+\angle \mathrm{A}>\mathrm{Bi}=
\end{aligned}
$$

Figure 51 shows that the experimental results are in good agreement with the predicted values calculated with $F^{*} A^{*} C * T$. In the same manner, Figure 52 shows good agreement between predicted and experimental values. The experimental curve indicates a sharp increase in $\mathrm{Sr}$ recovery for $\mathrm{Bi}$ addition between 0 and $1 \mathrm{wt} \%$. However, addition of more than $1 \mathrm{wt} \%$ of $\mathrm{Bi}$ does not indicate a major improvement in strontium recovery to the ingot.

The experimental measured strontium recoveries are lower than results obtained with the thermodynamic simulation. Thermodynamic simulations dealt with ideal systems which implied; no heat loss, no pressure change, perfect mixing, no material losses and no side reactions between the reactants and the media (impeller and crucible). These conditions are far from those achieved during the experimental works. 


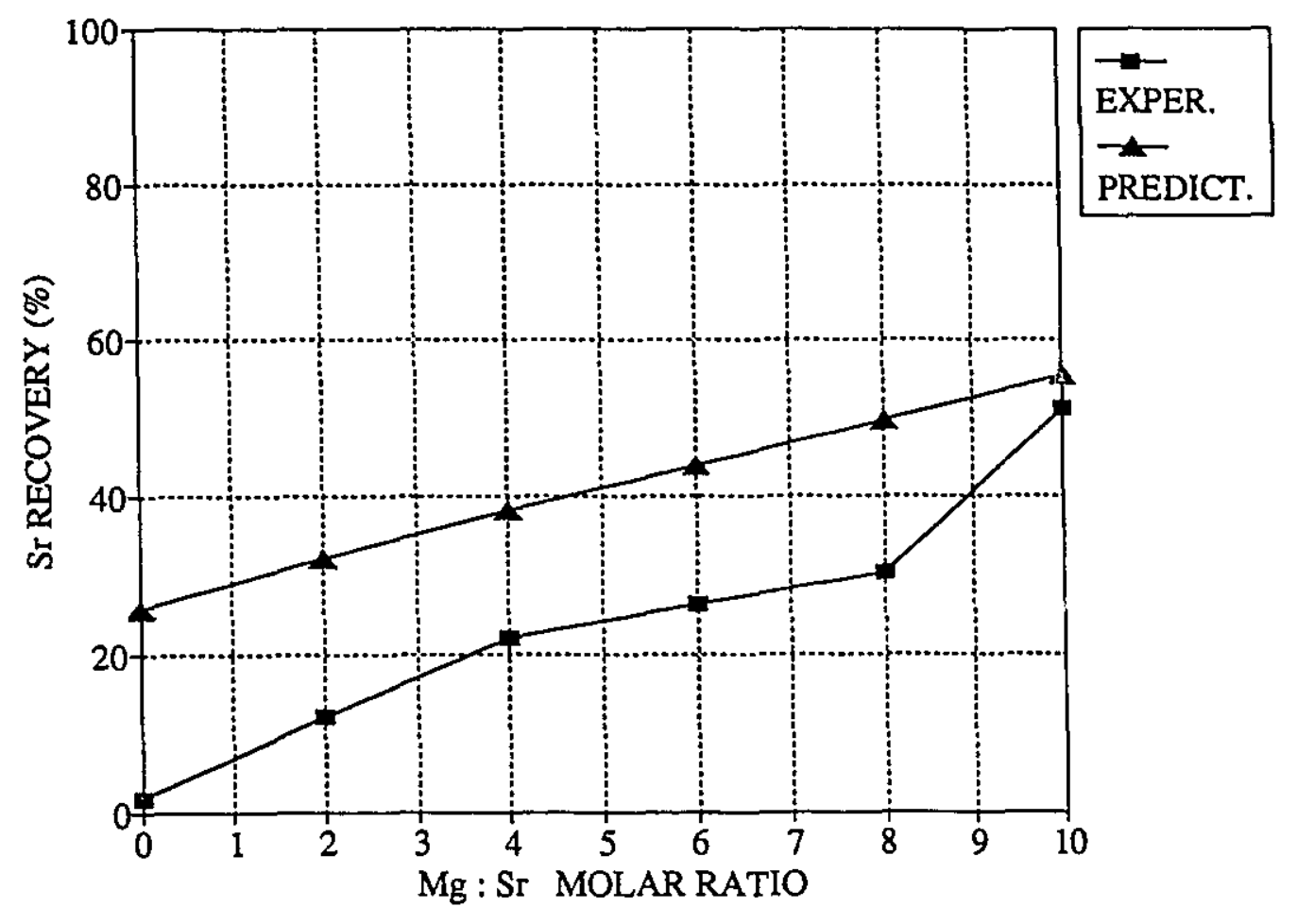

Figure 51 Experimental and Predicted $\mathrm{Sr}$ Recovery from $\mathrm{SrCO}_{3}$ (Magnesium Addition)

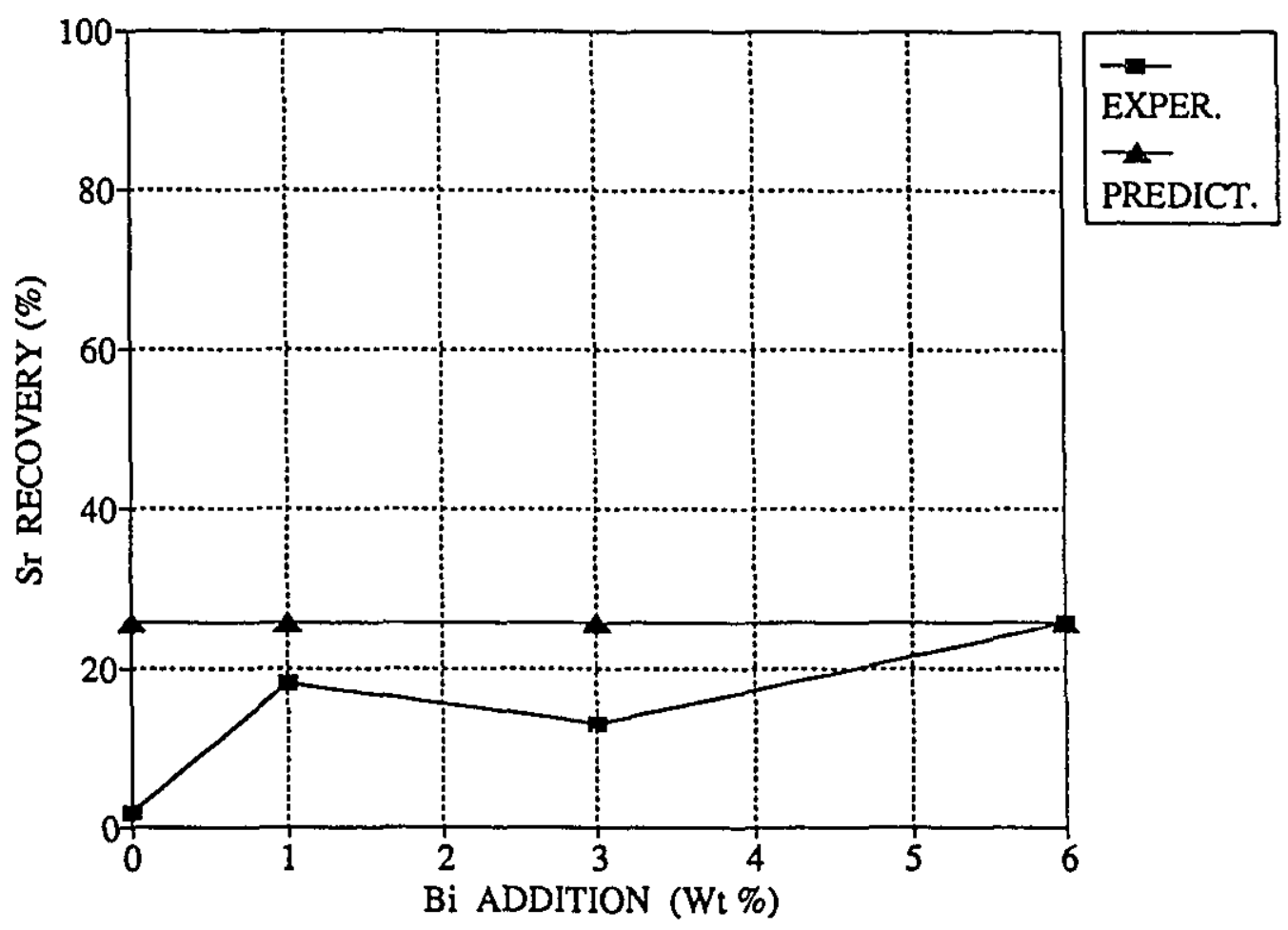

Figure 52 Experimental and Predicted Sr Recovery (Bismuth Addition) 
Thermodynamic simulation permits to perform many calculations by changing various parameters such as: temperature, pressure and reactant. Thermodynamic results can then be used as guideline for experimental work. The difference between the results obtained theoretically and experimentally could be attributed to a large number of parameters. The major factor, in this study, which greatly influenced the final experimental results was undoubtly the mixing. Poor mixing has resulted in bad solid/liquid contact imperative for reduction process to occur.

The other parameters responsible for the differences observed between the thermodynamic and the experimental results are listed below:
a) Temperature Fluctuation
b) Miscellaneous Material Losses
c) Analytical Errors
d) Unknown Wetting Characteristics of $\mathrm{SrCO}_{3}$
e) Scarcity of Data on Dissolved Species

Thermodynamic simulation showed direct relation between the temperature and the extraction. The temperature fluctuation during the experiments could have influenced the final results. Miscellaneous material losses and analytical errors have contributed to a certain extent the mass balance calculations. Better knowledge on the wetting behaviour of $\mathrm{SrCO}_{3}$ could be useful to develop optimum aluminum reductant containing additives. Finally, more information on the dissolved species in aluminum could be helpful for the understanding of complex mechanisms involved during the reduction process. 


\section{THERMODYNAMIC EVALUATION OF THE MLE PROCESS INVOLVING ALUMINOTHERMIC REDUCTION OF $\mathrm{SrCO}_{3}$}

This chapter presents a simulation of the aluminothermic reduction of strontium carbonate using the sub-routine EQUILIB in the $\mathrm{F}^{*} \mathrm{~A} * \mathrm{C} * \mathrm{~T}$ thermodynamic database. This simulation was performed by varying parameters such as temperature, pressure and the amount of excess molten reductant $(\mathrm{Al})$ and solute metal addition such as $\mathrm{Mg}$. The objective of the simulation was to observe the influence of these parameters on the strontium extraction.

Thermodynamic prediction of aluminothermic reduction of strontium carbonate was performed with five simulations:
a) Temperature Simulation
b) Pressure Simulation
c) Temperature and Pressure Dependence at $100 \%$ Strontium Extraction
d) Excess Aluminum Reductant Simulation
e) Strontium Extraction with Mg Addition and Temperature Variation

The first simulation consisted of varying the temperature from 800 to $1600{ }^{\circ} \mathrm{C}$ by increments of $100^{\circ} \mathrm{C}$ at a pressure of 1 atm. The inputs used for the simulation were

$$
\mathrm{SrCO}_{3}+100 \mathrm{Al}=
$$


The second simulation dealt with the pressure variation versus the strontium extraction. The pressure was varied from $1 \mathrm{E}-07$ atmosphere to 1 atmosphere by increments of $1 \mathrm{E}-1$ atmosphere while the temperature was kept constant at $1273 \mathrm{~K}$. The input, Equation 51, was used for this simulation also.

The third simulation was designed to show the pressure and the temperature dependence at $100 \%$ strontium extraction.

The fourth simulation examined the variation of the amount of the aluminum molten reductant on the strontium extraction. The temperature and pressure was set at $1273 \mathrm{~K}$ and 1 atmosphere, respectively. The input was:

$$
\mathrm{SrCO}_{3}+<\mathrm{A}>\mathrm{Al}-
$$

where $<A>$ was the number of mole of aluminum in the system which was increased from 1 to 5000 by increments of 500 .

The last simulation changed two parameters, the $\mathrm{Mg}: \mathrm{Sr}$ molar ratio which was increased from 0 to 30 by increments of 5 and the temperature which was changed from 800 to $1100^{\circ} \mathrm{C}$ by increments of $100^{\circ} \mathrm{C}$ for each of the $\mathrm{Mg}: \mathrm{Sr}$ ratios.

The results of the thermodynamic simulations are presented in Figures 53 to 57 . The first simulation is shown in Figure 53. The total amount of strontium extracted was determined by the total number of moles of free strontium calculated by the EQUILIB sub-routine. Other compounds containing strontium were not taken into account in the strontium extraction calculation. The simulations did not deal with gas phase dilution. It can be observed that the strontium extraction from $\mathrm{SrCO}_{3}$ increased exponentially as the temperature was increased. At a temperature of $1600^{\circ} \mathrm{C}, 100 \%$ strontium extraction was predicted. However, this is not a 


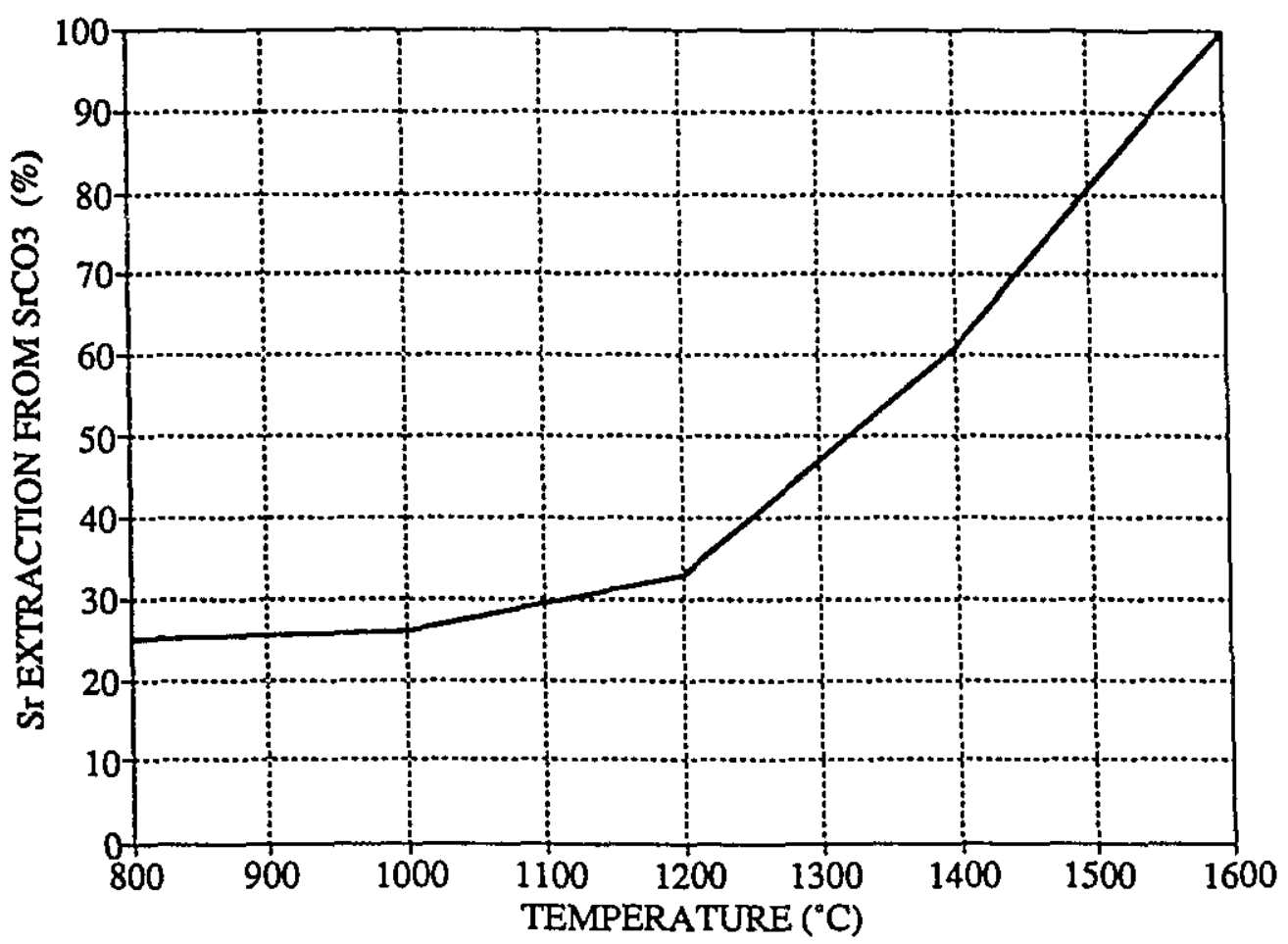

Figure $53 \mathrm{Sr}$ Extraction from $\mathrm{SrCO}_{3}$ vs. Temperature

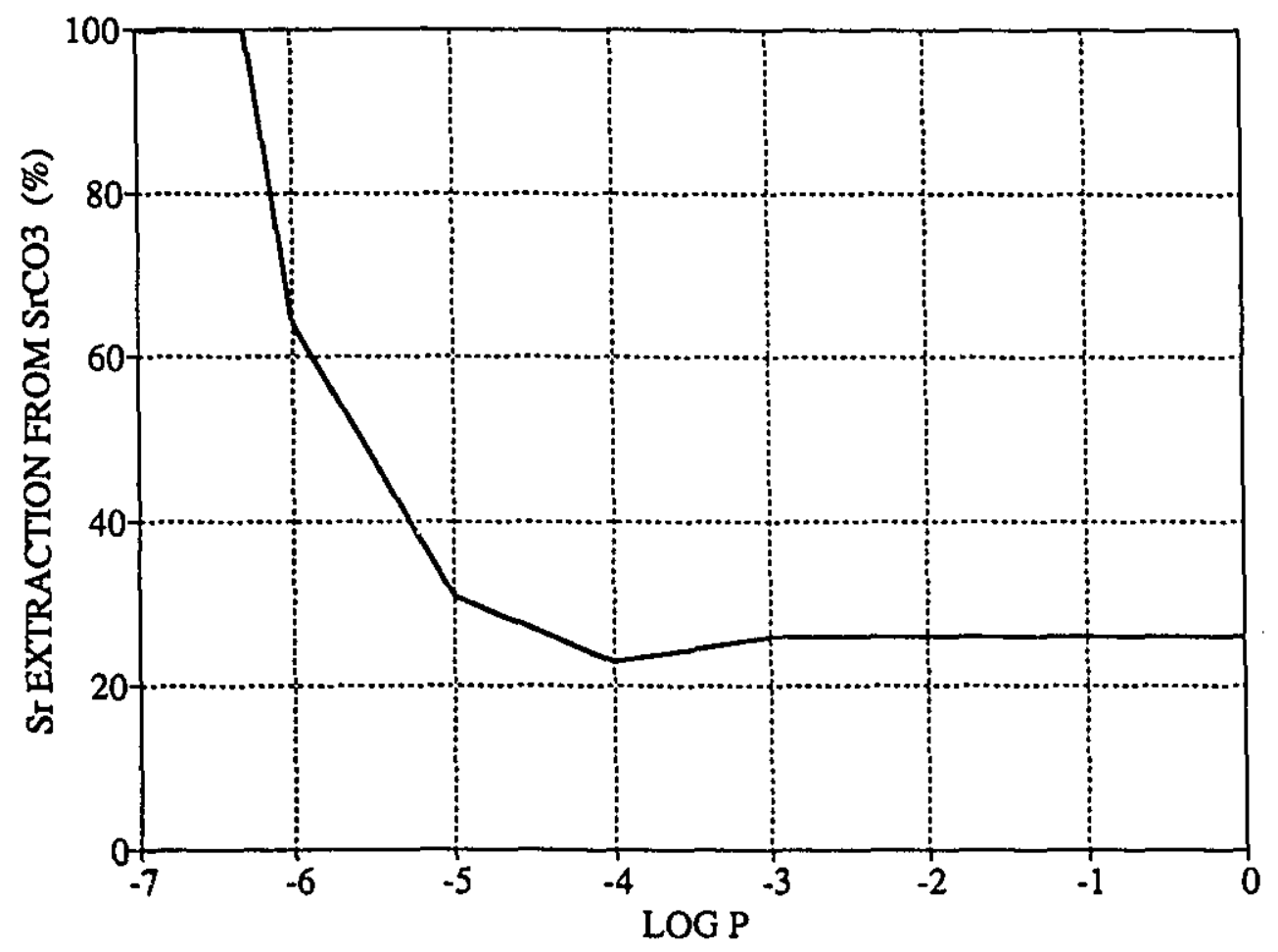

Figure $54 \mathrm{Sr}$ Extraction from $\mathrm{SrCO}_{3}$ vs. $\mathrm{Log} \mathrm{P}$ 
practical operating temperature since aluminum which fumedwould enter the vapour phase and contaminate the strontium condensate in a real process. Moreover, the reactor would be subjected to intense temperature resulting in short component life and high operating costs.

Figure 54 shows the pressure simulation results. It can be observed that the strontium extraction increased exponentially as the pressure decreased. At $6.3 \mathrm{E}-07$ atmosphere, 100\% strontium would enter the vapour phase. The temperature was $1273 \mathrm{~K}$ with an excess of aluminum reductant of 100 (100Al:Sr molar ratio).

Figure 56 presents the pressure and temperature dependence resulting for $100 \% \mathrm{Sr}$ extraction. This shows that the pressure required for $100 \%$ extraction can be increased by increasing the temperature of the system.

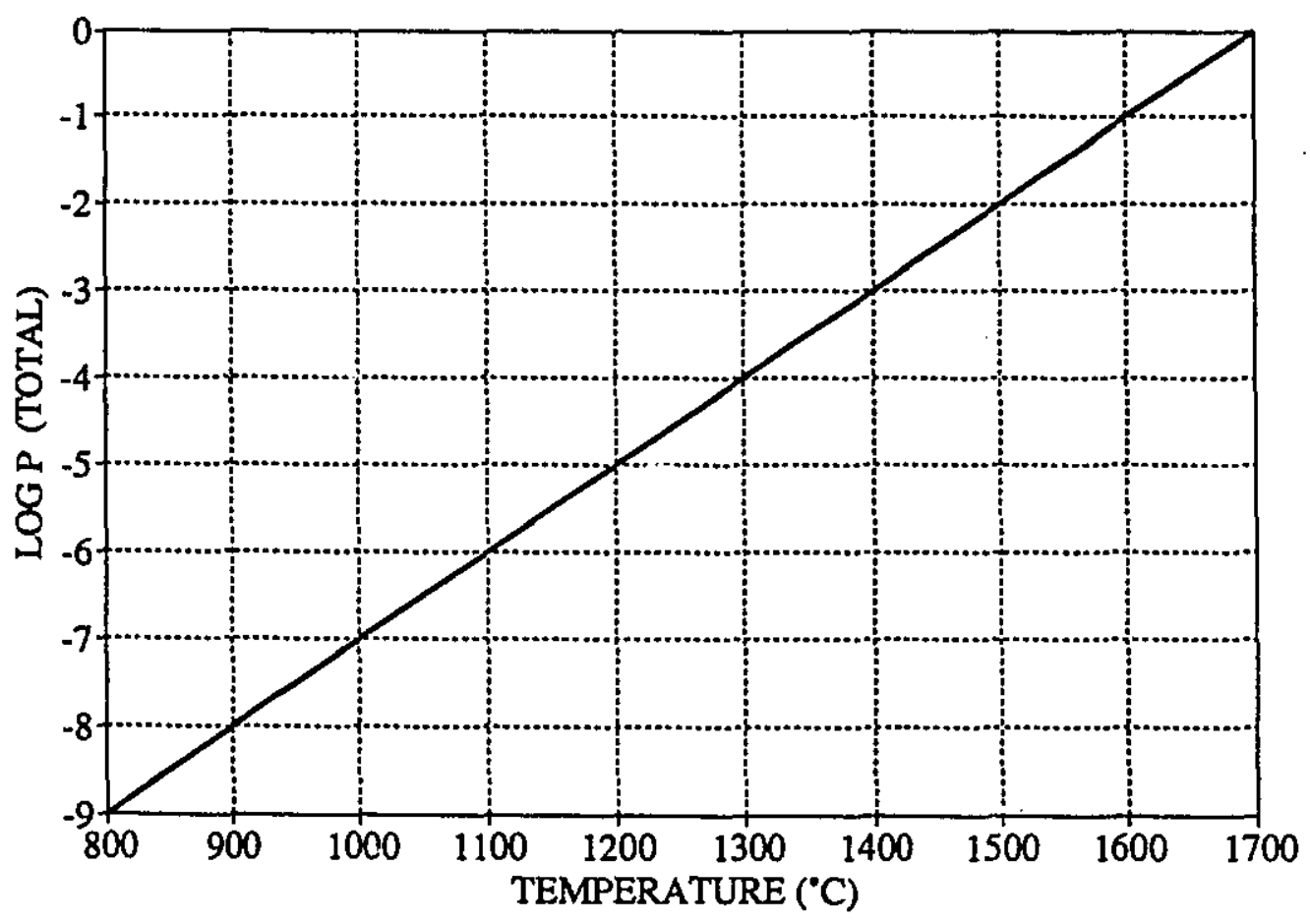

Figure 55 Pressure and Temperature Dependence at 100\% Sr Extraction 
Figure 55 shows that the extraction increased linearly with increasing the excess molten aluminum reductant. The simulation shows that $100 \%$ Sr extraction occurred when the moles of excess molten aluminum reductant was equal 2250 (2250Al:Sr molsr ratio). The last simulation is presented in Figure 57. By varying the Mg:Sr molar ratio and the temperature simultaneously, it can be seen that $100 \%$ strontium extraction can be obtained at $25 \mathrm{Mg}: \mathrm{Sr}$ molar

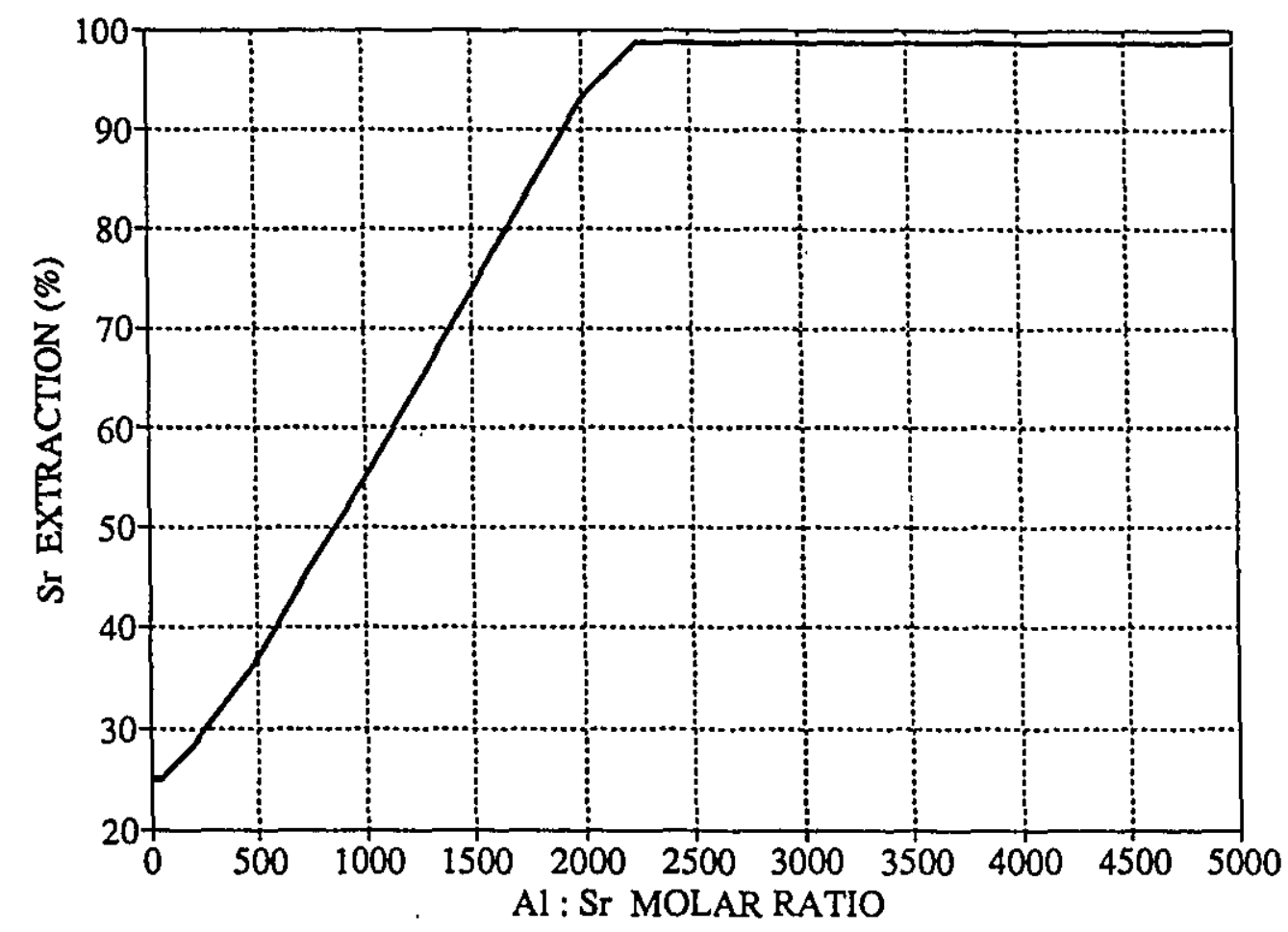

Figure 56 Sr Extraction vs. Al:Sr Molar Ratio

ratio. The extraction increases almost linearly for temperatures equal to $900^{\circ} \mathrm{C}, 1000^{\circ} \mathrm{C}$ and $1100^{\circ} \mathrm{C}$. There is an abrupt change in strontium extraction at $15 \mathrm{Mg}: \mathrm{Sr}$ molar ratio and $800^{\circ} \mathrm{C}$. This point could be interesting to examine experimentally since almost $85 \%$ extraction is predicted at atmospheric pressure and a relatively low temperature. The reason for this change could be the result of an optimum (e.g., minimum temperature and maximum pressure) 


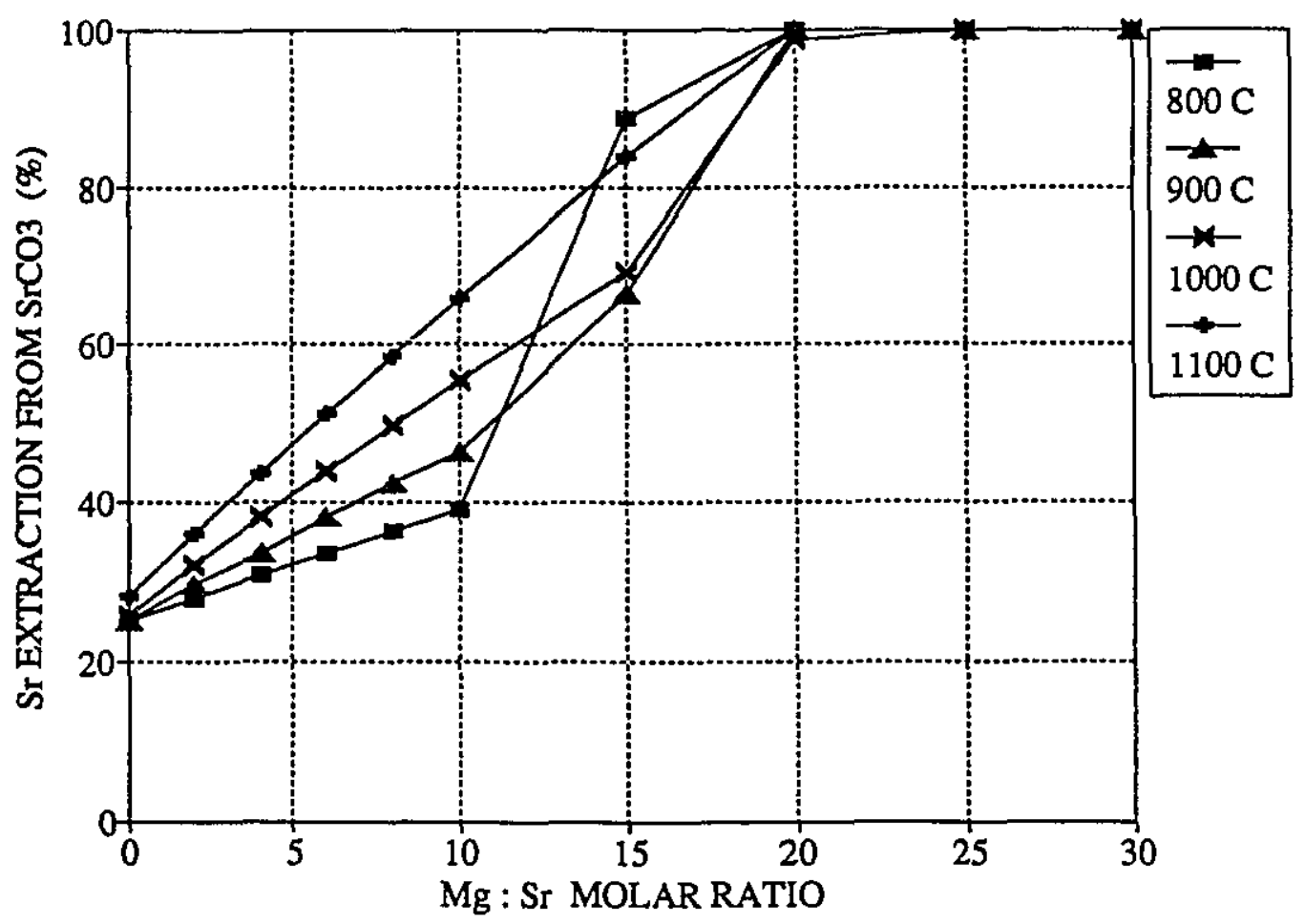

Figure $57 \mathrm{Sr}$ Extraction from $\mathrm{SrCO}_{3}$ vs. $\mathrm{Mg}: \mathrm{Sr}$ Molar Ratio and Temperature Variation

combination of temperature, pressure, amount of reactant and thermodynamic data used for the calculations.

The $\mathrm{F}^{*} \mathrm{~A}{ }^{*} \mathrm{C} * \mathrm{~T}$ simulation of the aluminothermic reduction of $\mathrm{SrCO}_{3}$ shows that $100 \%$ extraction can be achieved by increasing the temperature, the amount of excess reductant, by lowering the pressure of the system or by adding solute metal such as magnesium. Optimum behaviour can be determined by simulating many combinations of parameters which could be of great importance for the experimental program. Behaviour of complicated systems can be analyzed advantageously by thermodynamic simulation to predict parameters inherent to the feisibility and to contribute in time, effort and money savings. 


\section{CONCLUSIONS AND SUGGESTIONS FOR FUTURE WORKS}

\section{X.1 CONCLUSIONS}

In this work the extraction of strontium from strontium carbonate by metallothermic reduction using an excess of molten aluminum reductant has been investigated. The effects of magnesium and bismuth additions to the molten aluminum have also been studied. Magnesium was added to the melt to lower the surface tension of aluminum and to increase the oxygen affinity of the melt. Bismuth was added to the melt to lower the surface tension without increasing the oxygen affinity.

The conclusions drawn from the investigation are outlined below.

1. The main finding was that magnesium addition to the molten aluminothermic reduction process improves the strontium extraction from $\mathrm{SrCO}_{3}$.

2. The addition of bismuth did not improve significantly the strontium extraction.

3. The effect of magnesium and bismuth addition on the strontium extraction obtained experimentally was similar with the thermodynamic predictions using $F^{*} A^{*} C^{*} T$.

4. Magnesium and bismuth addition lowered the surface tension of the melt which improved the solid/liquid contact (wetting). 
5. The surface tension was not the only factor responsible for the improvement in strontium extraction from $\mathrm{SrCO}_{3}$ with magnesium addition.

6. The wetting process with magnesium could have involved the reduction of an impervious aluminum oxide film (aluminum oxide film reduction not possible with bismuth) improving the solid/liquid contact (indispensable for reduction and dissolution process).

7. Strontium was not found in the condensate. This suggests that lower pressure would be required to volatilize strontium at the temperature of the experiments $(1273 \mathrm{~K})$. It also suggests that magnesium and strontiurn can be preferentially recovered.

8. $\quad \mathrm{F} * \mathrm{~A} * \mathrm{C} * \mathrm{~T}$ simulation predicted $100 \%$ strontium extraction without magnesium addition by changing and combining thermodynamic parameters of the system such as: the amount of excess aluminitu, the temperature and pressure to obtain ideal conditions.

9. The rate of reaction increased with increasing the $\mathrm{Mg}: \mathrm{Sr}$ molar ratio. 


\section{X.2 FUTELE WORK}

The results suggest great potential to develop the full MLE process commercially for the production of strontium. It is evident, however, that more work is necessary to elaborate a fully developed process. In this section, some projects and tasks which could be useful for the complete elaboration of this unfamiliar process are proposed below:

a) A study, based on the MLE process, concerning the condensation of pure metal vapours to the liquid phase.

b) The study of the surface chemistry between $\mathrm{SrCO}_{3}$ and liquid metals involved in the aluminothermic reduction process.

c) The vacuum distillation of strontium from molten aluminum in presence of other solute metals.

d) The complete kinetics including mathematical modelling of the metallothermic reduction of $\mathrm{SrCO}_{3}$.

e) Study of the reaction mechanisms at the oxide particles and liquid metal interfaces. 
f) Experimental study of the aluminothermic reduction of $\mathrm{SrCO}_{3}$ under condition specified by $\mathrm{F}^{*} \mathrm{~A} * \mathrm{C} * \mathrm{~T}$ for $100 \%$ strontium extraction without metal solute addition.

g) The construction of a better reactor for future experimentation.

The reactor must be constructed in a way to; a) permit material addition or sampling under inert atmosphere or vacuum, b) to have intense agitation to insure full mixing of the reactants, c) to minimize material losses, d) to permit solid product residue remeval from the melt, e) to have a close control on the operating temperature and f) to condense metal vapours. These proposals would lead eventually to the development of a continuous process for the strontium production based on the MLE process. 


\section{X.3 CONTRIBUTION TO KNOWLEDGE}

The results of this research demonstrated that the surface tension was not the only factor responsible for the improvement in strontium recovery with magnesium addition. This informatior will contribute greatly to subsequent research concerning the study of the full mechanism governing the aluminothermic reduction of Group IA or IIA metals with solute metal additions. 


\section{REFERENCES}

1. R. Harris, A.E. Wraith and J. Toguri, Producing Volatile Metals, Canadian Patent Application, Ser. No.: 539,058, June 8, 1987, USA Patent Application, Ser. No.: 201,446, June 2, 1988

2. Harris, R.L., Vacuum Refining of Molten Steel, Ph.D. Thesis, McGill University, 1980

3. Dimayuga, F., Vacuum Refining of Molten Aluminum, Ph.D. Thesis, mcGill University, 1980

4. Olette, M., Vacuum Distillation of Minor Elements from Liquid Ferrous Alloys, Physical Chemistry of Process Metallurgy, Part 2, Ed. by G. St-Pierre, Interscience, N.Y., 1961, pp. 1065-87

5. Werner, E., Materials of High Vacuum Technology, Vol. 1, Metals and Metalloids, Pergamon Press, 1966, pp. 576-90

6. Volsky, A.N. et al., Refining of Strontium, Barium, Magnesium and Calcium, Session C9, P/2050, USSR

7. Ward, A.G., The Purification of Lithium by Vacuum Distillation, J. Appl. Chem., 13, August 1963, pp. 329-34

8. Albert, E., Strontium: A Materials Survey, Information Circulaire 7933, USA, Washington, 1959, 45p.

9. Caldwell Jr., H.S., Gas Fired Vacuum Retort for Distilling Metal, U.S. Dept. of the Int. Bur. of Mines, Report No. 5764, 1961

10. Periodic Table of the Elements, Sargent-Welch Scientific Company, Catalog No. S-18806, 1980

11. Cameron, A.E., J. Am. Chem. Soc., 84 (1962), p. 4182

12. Annual Review of Physical Chemistry, H. Eyring Ed., Vol. 12, 1961, p. 32

13. American Ceramic Society Bulletin, Vol.68, No.5, 1989, p. 1068

14. Minerals Yearbook, U.S. Department of the Interior, Bureau of Mines, Vol. III, 1987

15. Industrial Mineral and Rocks (Nonmetallics other than Fuels), Fifth Edition, Vol. 2, 1983 
16. Mineral Yearbook, Bureau of Mines, Vol. 1, 1987, pp. 967-9

17. Trutman-Dickenson A.F., Comprehensive Inorganic Chemistry, Pergamon Press, Oxford, 1973, p. 592

18. Handbook of Preparative Inorganic Chemistry, Vol. 1, Second Ed., Academic Press, NY, 1963, pp. 922-33

19. Guntz, A., Les Sous-Sels Alcalino-Terreux, Bulletin de la Société Chimique, $4^{\circ}$ Ser., Tome 35, 1924, pp. 709-28

20. Guntz, M.A., Annales de Chimie et de Physique, Série 8, Tome 10, 1907, pp. 437-50

21. Guntz, A., Comptes Rendus des Scéances de l'Académie des Sciences, Tome 151, 1910, p. 813

22. Gvalesian, G.G., Works of the Institut of Metallurgy, CCCP, Vol. 12, 1961, pp. 103-18

23. Habashi, F., Principles of Extractive Metallurgy, Vol. 3 Pyrometallurgy, Gordon and Breach Science Publishers, 1986

24. Production and Electrolysis of Light Metals, Ed. by Bernard Closset, Proceedings of the International Symposium, August 20-24, 1989, pp. 249-56

25. The Extraction of Strontium from the Mineral Celestite, Dept. of Energy, Mines \& Resources, Canada, Research Report M38-1/R223, April 1970, 32p.

26. Carbonates: Mineralogy and Chemistry, Reeder, Richard J., Ed. Reviews in Mineralogy, Vol. 11, ISBN 0-939950-15-4, OMSA 1983, pp. 145-190

27. Pauling, L., The Nature of the Chemical Bond, Cornell Univ. Press, Ithaca, N.Y., Third ed., 1960 , pp. $282-3$

28. Richardson, F.D., Physical Chemistry of the Melts in Metallurgy, Vol. 2, @1974 Academic Press, London

29. Aluminum, Properties and Physical Metallurgy, Ed. John E. Hatch, 1984, ASM, pp. 14-19

30. Smithells, C.J., Ed, Metals Reference Book, Fifth Ed., Butterworths, London, UK, 1967

31. Bohdansky, J., Surface Tension and density of the Liquid Earth Alkaline Metals Mg, Ca, Sr, Ba, J. Inorg. Nucl. Chem., 1968, Vol. 30, pp. 2331-7 
32. McGonical, P.J., J. Phys. Chem., Vol. 66, 1962, p. 737-40

33. Gilchrist, J.D., Eantraction Metallurgy, $2^{\text {nd }}$ Ed., Pergamon Press, 1980

34. $F^{*} A^{*} C^{*} T$ (Facility for the Analysis of Chemical Thermodynamics), W.T. Thompson, A.D. Pelton and C.W. Bale, CRCT, Ecole Polytechnique, Montréal, 1988

35. Hultgren, R., Selected Values of Thermodynamic Properties of Metals and Alloys, ASM, 1973

36. Alcock, C.B., The Al-Sr System, Bulletin of Alloy and Phase Diagrams, Vol. 10, No. 6, 1989, pp.624-30

37. Sigworth, G.K., Scandinavian Journal of Metallurgy, 11 (1982), pp. 143-9

38. Holland, F.A., Kirid Flow for the Chemical Engineers, E. Arnold (Publishers) Ltd., London, 1973, pp. 103-5

39. APD (Automated Powder Diffraction) 1700, Operation Manual, First ed., Phillips Corp., Netherlands, 1984

40. Chemical Analysis, Vol. 25, @John Wiley \& Sons, 1968, pp. 164-72

41. Intonti, R., Spectrochimica Acta, Vol. 23B, 1968, pp. 437-42

42. Condylis, A., Fourth International Conference on Atomic Spectroscopy, Toronto, Ont., 1973 , p. 64 , p. 115

43. Heffernan, B.J., Laboratory Methods, Vol. 83, No. 500, 1971, pp. 205-7

44. Soters, J., Atomic Absorption Method Manual, Vol.1, Instr. Lab. Inc., Washington, Ma., 1979

45. A.A. Model IL357, Instrumentation Laboratory Manual

46. JEOL (U.S.A) Inc. 11 Dearbon Rd., Peabody, Mass., 01960

47. Tracor Northern, 2551 W. Beltline, Middleton, Wis., 1985

48. Scanning Electron Microscope Analysis of Materials, Professional Development Seminars, McGill University, Dept. of Mining and Metallurgical Engineering, 1990

49. Havner, S.H., Introduction to Physical Metallurgy, Second Edition, McGraw-Hill, 1974, pp. $15-24$ 
50. Carnahan, R.D., Some Observations on the Wetting of $\mathrm{Al}_{2} \mathrm{O}_{3}$ by Aluminum, Journ. Amer. Cer. Soc., Vol. 41, No. 9, 1958, pp. 343-7

51. QUATTRO PRO, Release 1.0, Borland International, Scotts Valley, CA

52. Gary, D.C., Analytical Chemistry, Second ed., John Wiley \& Sons, 1971, 1977, pp. 59-76

53. Harris, Daniel C., Quantitative Chemical Analysis, Second Edition, (C1987 W.H. Freeman, USA, pp. 1-113, pp. 572-89

54. Closset, B., Metall. Trans. A, 1986, vol. 17A, pp. 1250-3

55. Sommer, F., Z. Metallkde, Bd. 74 (1983) H.2, pp. 100-4

56. Evers, J., Preparation and Characterization of High Purity Calcium, Strontium and Barium, J. of Less-Common Metals, 81 (1981), pp. 15-31

57. Burylev, B.P., Russian Journal of Physical Chemistry, 48 (6), 1974, pp. 809-11

58. Makhmudov, M.M., Bodak, O.I., Phase Equilibria in the Mg-Al-Sr System, UDC 669.721.71.892, pp. 209-12

59. The Al-Mg System by J.L. Murray, Bulletin of Alloy Phase Diagrams, Vol. 3, No. 1, 1982 , p. 108

60. The Al-Sr System by C.B. Alcock and V.P. Itkin, Bulletin of Alloy Phase Diagrams, Vol. 10, No. 6,1989 , p. 684

61. The Al-Bi System by A.J. McAlister, Bulletin of Alloy Phase Diagrams, Vol. 5, No. 3, 1984, p. 302

62. The Mg-Sr System by A.A. Nayeb-Hashemi and J.B. Clark, Bulletin of Alloy Phase Diagrams, Vol. 7, No. 2, 1986, p. 178

63. The Bi-Sr System by R.P. Elliot, Constitution of Binary Alloys, First Supplement, (C1965 McGraw-Hill, p. 199 


\section{APPENDIX A}

The $\mathrm{F}^{*} \mathrm{~A} * \mathrm{C}^{*} \mathrm{~T}$ simulation of the aluminothermic reduction of $\mathrm{SrCO}_{3}$ with magnesium and bismuth addition is shown below.

The species identified with " $<---"$ have been drawn from the private data collection created for dissolved species in molten aluminum. Product species identified with " $T$ " have been extrapolated from its normal temperature range. The cutoff concentration was set at $1 \times 10^{-5}$. Product species with a concentration or activity less than the cutoff value were not listed.

\section{MAGNESIUM ADDITION}

SR1C1O3+100AL+<A $>\mathrm{MG}=$

$$
\begin{aligned}
& 0.00000 \mathrm{E}+00 \\
& \text { ( } 0.11150 \mathrm{E}-03 \text { Sr } \\
& \text { ( } 1273.0,1.00 \text {,G ,0.112E-03 } \\
& +97.432 \quad(0.99721 \quad \mathrm{Al} \\
& +0.26306 \mathrm{E}-02 \quad \mathrm{Sr} \\
& +0.12595 \mathrm{E}-03 \quad \mathrm{Al} 2 \mathrm{O} 3
\end{aligned}
$$

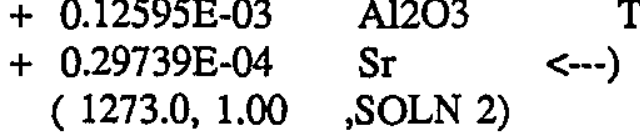

$$
\begin{aligned}
& +0.74080 \quad \text { (SrO)(A12O3) } \\
& \text { (1273.0, } 1.00 \quad, \mathrm{~S} 2,1.0000) \\
& +0.33333 \quad \text { Al4C3 } \\
& (1273.0,1.00 \quad, \mathrm{~S} 1,1.0000)
\end{aligned}
$$$$
\text { T) }
$$

where ' $\mathrm{A}$ ' on the reactant side is $0.0000 \mathrm{E}+00 \mathrm{Mg}: \mathrm{Sr}$ molar ratio $=0$

$\mathrm{SR} 1 \mathrm{ClO}+100 \mathrm{AL}+<\mathrm{A}>\mathrm{MG}=$

$0.00000 \mathrm{E}+00$

$(0.36240 \mathrm{E}-02 \quad \mathrm{Mg}$

$\mathrm{T}$ 


$$
\begin{aligned}
& +0.12370 \mathrm{E}-03 \quad \mathrm{Sr} \quad \mathrm{T}) \\
& \text { (1273.0, } 1.00, G, 0.375 \mathrm{E}-02 \text { ) } \\
& +98.528
\end{aligned}
$$

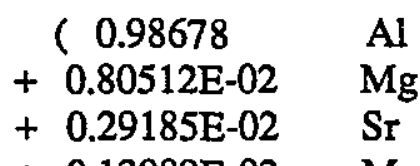

$$
\begin{aligned}
& +0.13089 \mathrm{E}-02 \quad \mathrm{MgO} \quad \mathrm{T} \\
& \begin{array}{rlr}
+0.78931 \mathrm{E}-03 & \mathrm{Mg} & <-- \\
+0.11590 \mathrm{E}-03 & \mathrm{Al} 2 \mathrm{O} & \mathrm{T}
\end{array} \\
& +0.32993 \mathrm{E}-04 \text { Sr }<--) \\
& \text { (1273.0, } 1.00 \text {,SOLN 2) } \\
& +0.70920 \quad(\mathrm{SrO})(\mathrm{Al2O} 3) \\
& \text { (1273.0, } 1.00 \text {,S2, } 1.0000 \text { ) } \\
& +0.33333 \quad \mathrm{Al} 4 \mathrm{C} 3 \\
& (1273.0,1.00 \quad \mathrm{~S} 1,1.0000)
\end{aligned}
$$

where ' $A$ ' on the reactant side is $1.000 \mathrm{Mg}: \mathrm{Sr}$ molar ratio $=1$

SR1C1O3+100AL $+<A>M G=$

$$
\begin{aligned}
& 0.00000 \mathrm{E}+00 \\
& \text { ( 0.71843E-02 } \mathrm{Mg} \\
& +0.13529 \mathrm{E}-03 \text { Sr } \\
& \text { ( 1273.0, } 1.00 \text {,G ,0.732E-02 } \\
& +99.621
\end{aligned}
$$

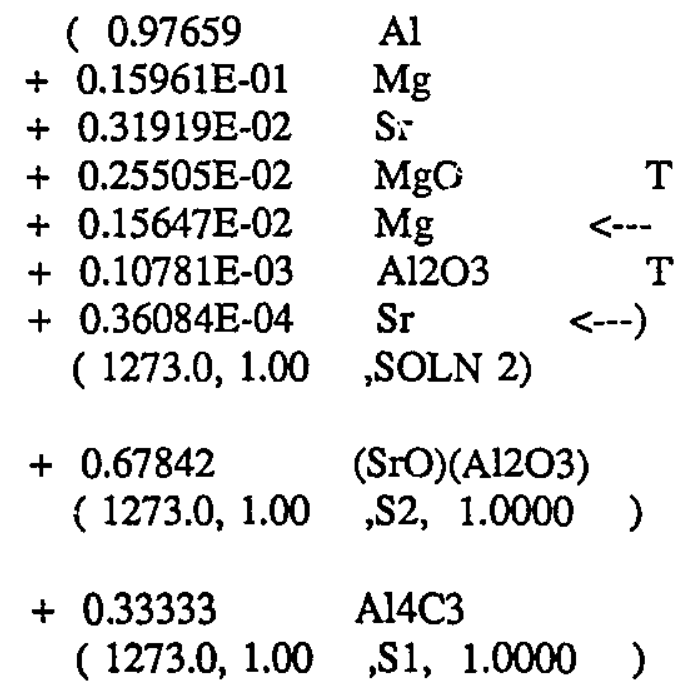$$
\mathrm{T}
$$$$
\text { T) }
$$$$
\text { ) }
$$

where ' $\mathrm{A}$ ' on the reactant side is $2.000 \mathrm{Mg}: \mathrm{Sr}$ molar ratio $=2$ 
SR1C1O3+100AL $+<A>M G=$

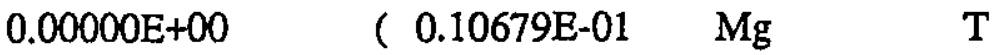

$$
\begin{aligned}
& +0.14637 \mathrm{E}-03 \text { Sr } \quad \mathrm{T}) \\
& \text { ( } 1273.0,1.00, \mathrm{G}, 0.108 \mathrm{E}-01) \\
& +100.71
\end{aligned}
$$

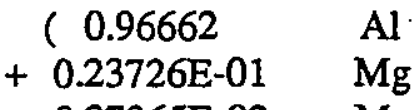

$$
\begin{aligned}
& +0.37365 \mathrm{E}-02 \quad \mathrm{MgO} \quad \mathrm{T} \\
& +0.34533 \mathrm{E}-02 \quad \mathrm{Sr} \\
& \begin{array}{rlr}
+0.23260 \mathrm{E}-02 & \mathrm{Mg} & <-- \\
+ & 0.10111 \mathrm{E}-03 & \mathrm{Al} 2 \mathrm{O} 3
\end{array} \\
& \text { ( } 1273.0,1.00 \text {,SOLN 2) } \\
& +0.64828 \quad(\mathrm{SrO})(\mathrm{Al} 2 \mathrm{O} 3) \\
& (1273.0,1.00 \quad, \mathrm{~S} 2,1.0000) \\
& +0.33333 \quad \mathrm{Al} 4 \mathrm{C3} \\
& (1273.0,1.00 \quad, S 1,1.0000)
\end{aligned}
$$

where ' $\mathrm{A}$ ' on the reactant side is $3.000 \mathrm{Mg}: \mathrm{Sr}$ molar ratio $=3$

SR1C1O3+100AL $+<A>M G=$

$$
\begin{aligned}
& 0.00000 \mathrm{E}+00 \\
& \text { ( 0.14109E-01 M } \\
& +0.15701 \mathrm{E}-03 \quad \mathrm{Sr} \\
& \text { ( } 1273.0,1.00 \text {,G ,0.143E-01 } \\
& \mathrm{T} \\
& \text { T) } \\
& +101.80
\end{aligned}
$$

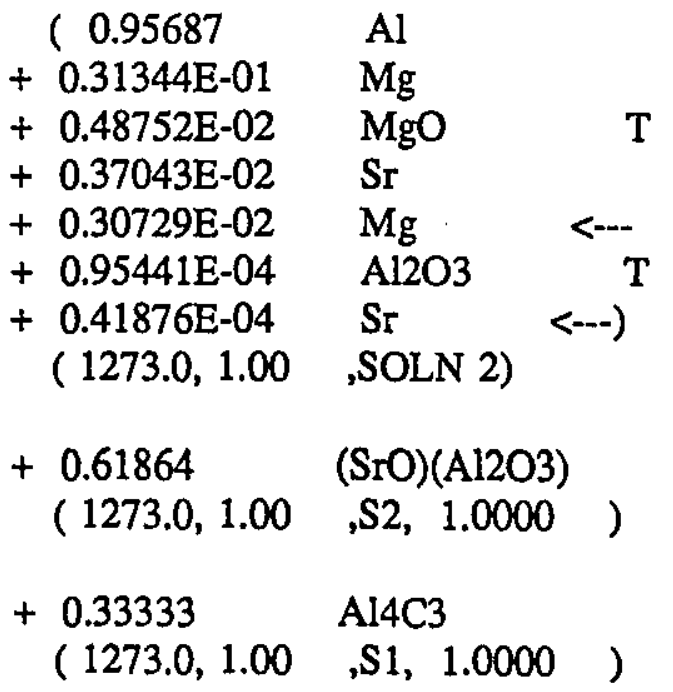


where ' $\mathrm{A}$ ' on the reactant side is $4.000 \mathrm{Mg}: \mathrm{Sr}$ molar ratio $=4$

SR1C1O3+100AL $+<A>M G=$

$$
\begin{aligned}
& 0.00000 \mathrm{E}+00 \\
& \text { ( 0.17473E-01 } \mathrm{Mg} \\
& +0.16726 \mathrm{E}-03 \quad \mathrm{Sr} \\
& \text { (1273.0,1.00 ,G ,0.176E-01 ) } \\
& +102.89
\end{aligned}
$$

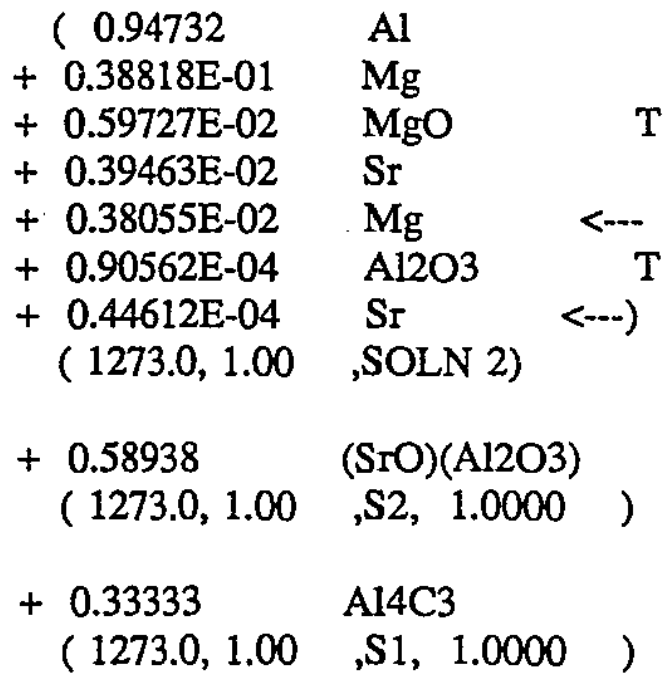

where ' $\mathrm{A}$ ' on the reactant side is $5.000 \mathrm{Mg}: \mathrm{Sr}$ molar ratio $=5$

$$
\begin{aligned}
& \text { SR1C1O3+100AL }+<A>M G= \\
& 0.00000 \mathrm{E}+00 \\
& \text { ( } 0.20772 \mathrm{E}-01 \quad \mathrm{Mg} \quad \mathrm{T} \\
& +0.17718 \mathrm{E}-03 \quad \mathrm{Sr} \quad \mathrm{T}) \\
& \text { (1273.0, } 1.00 \text {, G ,0.209E-01 ) } \\
& +103.98
\end{aligned}
$$

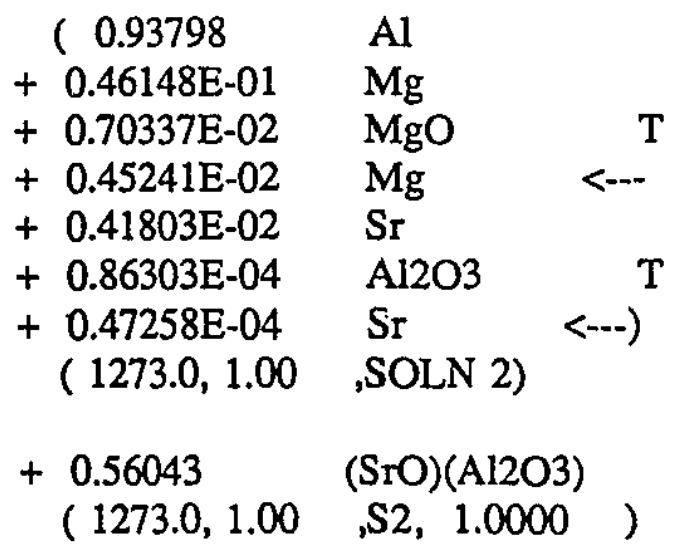




$$
\begin{array}{ll}
0.33333 & \text { Al4C3 } \\
(1273.0,1.00 \quad \text { S } 1,1.0000)
\end{array}
$$

where ' $\mathrm{A}$ ' on the reactant side is $6.000 \mathrm{Mg}: \mathrm{Sr}$ molar ratio $=6$

SR1C1O3+100AL+ $\angle A>M G=$

$$
\begin{aligned}
& 0.00000 \mathrm{E}+00 \\
& \text { ( 0.24008 }-01 \quad \mathrm{Mg} \\
& +0.18650 \mathrm{E}-03 \mathrm{Sr} \\
& \text { (12.3.0, } 1.00 \text {,G ,0.242E-01 ) } \\
& +105.06
\end{aligned}
$$

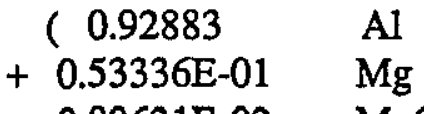

$$
\begin{aligned}
& +0.80621 \mathrm{E}-02 \quad \mathrm{MgO} \\
& +0.52288 \mathrm{E}-02 \quad \mathrm{Mg} \quad<-- \\
& +0.44071 \mathrm{E}-02 \quad \mathrm{Sr} \\
& +0.82544 \mathrm{E}-04 \quad \mathrm{Al} 2 \mathrm{O} 3 \mathrm{~T} \\
& +0.49822 \mathrm{E}-04 \quad \mathrm{Sr} \quad<--) \\
& \text { (1273.0, } 1.00 \text {,SOLN 2) } \\
& +0.53174 \quad \text { (SrO)(Al2O3) } \\
& \text { (1273.0, } 1.00 \quad, \mathrm{~S} 2,1.0000) \\
& +0.33333 \quad \mathrm{Al} 14 \mathrm{C} 3 \\
& (1273.0,1.00 \quad, S 1,1.0000)
\end{aligned}
$$

where ' $\mathrm{A}$ ' on the reactant side is $7.000 \mathrm{Mg}: \mathrm{Sr}$ molar ratio $=7$

SR1C1O3+100AL $+<A>M G=$

$$
\begin{aligned}
& 0.00000 \mathrm{E}+00 \\
& \text { ( 0.27181E-01 M } \\
& +0.19614 \mathrm{E}-03 \quad \mathrm{Sr} \\
& (1273.0,1.00, \mathrm{G}, 0.274 \mathrm{E}-01) \\
& +106.15 \\
& \text { ( } 0.91987 \\
& +0.60385 \mathrm{E}-01 \\
& +0.90608 \mathrm{E}-02 \\
& +0.59199 \mathrm{E}-02 \\
& +0.46275 \mathrm{E}-02 \\
& +0.79194 \mathrm{E}-04 \\
& +0.52313 \mathrm{E}-04 \\
& \text { (1273.0, } 1.00 \\
& \mathrm{Al} \\
& \mathrm{Mg} \\
& \mathrm{MgO} \\
& \mathrm{Mg} \\
& \mathrm{Sr} \\
& \mathrm{Al} 2 \mathrm{O} 3 \mathrm{~T} \\
& \text { Sr <--) } \\
& \text {,SOLN 2) }
\end{aligned}
$$

T)

.




$$
\begin{aligned}
& \left.+\begin{array}{ll}
0.50325 & (\mathrm{STO})(\mathrm{Al} 2 \mathrm{O} 3) \\
(1273.0,1.00 & , \mathrm{S} 2,1.0000
\end{array}\right) \\
& \left.+\begin{array}{ll}
0.33333 & \mathrm{Al} 4 \mathrm{C} 3 \\
(1273.0,1.00 & , \mathrm{S} 1,1.0000
\end{array}\right)
\end{aligned}
$$

where ' $A$ ' on the reactant side is $8.000 \mathrm{Mg}: \mathrm{Sr}$ molar ratio $=8$

SR1C1O3+100AL $+<A>M G=$

$$
\begin{aligned}
& 0.00000 \mathrm{E}+00 \\
& \text { ( } 0.30293 \mathrm{E}-01 \quad \mathrm{Mg} \\
& +0.20522 \mathrm{E}-03 \mathrm{Sr} \\
& \text { (1273.0, } 1.00 \text {,G ,0.305E-01) } \\
& +107.23 \\
& \text { ( } 0.91110 \\
& +0.67299 \mathrm{E}-01 \\
& +0.10032 \mathrm{E}-01 \\
& +0.65977 \mathrm{E}-02 \\
& +0.48419 \mathrm{E}-02 \\
& +0.76183 \mathrm{E}-04 \\
& +0.54737 \mathrm{E}-04 \\
& \text { (1273.0, } 1.00 \\
& \text { Al } \\
& \mathrm{Mg} \\
& \mathrm{MgO} \\
& \text { T } \\
& \mathrm{ST} \\
& \mathrm{Al} 2 \mathrm{O} 3 \\
& \mathrm{Sr} \\
& \text {,SOLN 2) } \\
& +0.47492 \\
& \text { (1273.0, } 1.00 \\
& \text { (SrO)(Al2O3) } \\
& +0.33333 \\
& \mathrm{Al} 4 \mathrm{C} 3 \\
& \text { (1273.0, } 1.00 \\
& \text {,S2, } 1.0000 \text { ) } \\
& \text {,S1, } 1.0000 \text { ) }
\end{aligned}
$$

where ' $\mathrm{A}$ ' on the reactant side is $9.000 \mathrm{Mg}: \mathrm{Sr}$ molar ratio $=9$

$\mathrm{SR} 1 \mathrm{C} 1 \mathrm{O} 3+100 \mathrm{AL}+<\mathrm{A}>\mathrm{MG}=$

$$
\begin{aligned}
& 0.00000 \mathrm{E}+00 \\
& \text { ( 0.33344E-01 } \mathrm{Mg} \\
& +0.21408 \mathrm{E}-03 \mathrm{Sr} \\
& (1273.0,1.00, G, 0.336 \mathrm{E}-01) \\
& +108.32 \\
& \text { ( } 0.90250 \\
& +0.74079 \mathrm{E}-01 \\
& +0.10979 \mathrm{E}-01 \\
& +0.72624 \mathrm{E}-02 \\
& +0.50508 \mathrm{E}-02 \\
& \mathrm{Al} \\
& \mathrm{Mg} \\
& \mathrm{MgO} \\
& \mathrm{Mg}<-- \\
& \mathrm{Sr}
\end{aligned}
$$

)




$$
\begin{aligned}
& +0.73458 \mathrm{E}-04 \quad \mathrm{Al} 2 \mathrm{O} 3 \mathrm{~T} \\
& +0.57098 \mathrm{E}-04 \text { Sr <---) } \\
& \text { (1273.0, } 1.00 \text {,SOLN 2) } \\
& +0.44672 \quad(\mathrm{SrO})(\mathrm{Al} 2 \mathrm{O} 3) \\
& (1273.0,1.00 \quad \mathrm{~S} 2,1.0000) \\
& \begin{array}{ll}
0.33333 & \mathrm{Al} 4 \mathrm{C} 3 \\
(1273.0,1.00 & , \mathrm{S} 1,1.0000)
\end{array}
\end{aligned}
$$

where ' $\mathrm{A}$ ' on the reactant side is $10.00 \mathrm{Mg}: \mathrm{Sr}$ molar ratio $=10$ 


\section{BISMUTH ADDITION}

$\mathrm{SR} 1 \mathrm{C} 1 \mathrm{O} 3+100 \mathrm{AL}+\angle \mathrm{A}>\mathrm{BI}=$

$$
\begin{aligned}
& 0.00000 \mathrm{E}+00 \\
& \text { ( } 0.11150 \mathrm{E}-03 \quad \mathrm{Sr} \\
& \text { ( 1273.0, } 1.00, \mathrm{G}, 0.112 \mathrm{E}-03 \text { ) } \\
& +97.432 \\
& \begin{array}{rr}
(0.99721 & \mathrm{Al} \\
+0.26306 \mathrm{E}-02 & \mathrm{St}
\end{array} \\
& +0.12595 \mathrm{E}-03 \quad \mathrm{Al} 2 \mathrm{O} 3
\end{aligned}
$$

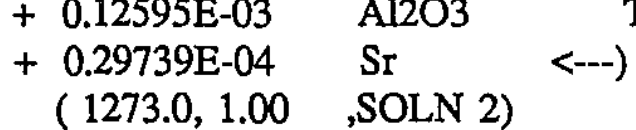

$$
\begin{aligned}
& +0.74080 \quad \text { (StO)(Al2O3) } \\
& (1273.0,1.00 \quad, \mathrm{~S} 2,1.0000) \\
& +0.33333 \quad \mathrm{Al} 4 \mathrm{C} 3 \\
& \text { (1273.0, } 1.00 \quad, \mathrm{~S} 1,1.0000)
\end{aligned}
$$

where' 'A' on the reactant side is $0.0000 \mathrm{E}+00$

$\mathrm{SR} 1 \mathrm{C} 1 \mathrm{O} 3+100 \mathrm{AL}+\angle \mathrm{A}>\mathrm{BI}=$

$$
\begin{aligned}
& 0.00000 \mathrm{E}+00 \\
& \text { ( 0.11144E-03 Sr } \\
& (1273.0,1.00, \mathrm{G}, 0.113 \mathrm{E}-03) \\
& +97.482 \\
& \begin{aligned}
& (0.99670 \\
+ & 0.26293 \mathrm{E}-02 \\
+ & 0.51291 \mathrm{E}-03 \\
+ & 0.12596 \mathrm{E}-03 \\
+ & 0.29724 \mathrm{E}-04 \\
& (1273.0,1.00
\end{aligned} \\
& \text { Al } \\
& \text { Sr } \\
& \mathrm{Bi} \\
& \mathrm{Al2O} 3 \mathrm{~T} \\
& \mathrm{Sr} \quad<--) \\
& \text {,SOLN 2) } \\
& +0.74079 \quad(\mathrm{SrO})(\mathrm{Al} 2 \mathrm{O} 3) \\
& (1273.0,1.00 \quad, \mathrm{~S} 2,1.0000) \\
& +0.33333 \quad \mathrm{Al} 4 \mathrm{C} 3 \\
& (1273.0,1.00 \quad, S 1,1.0000)
\end{aligned}
$$

where ' $\mathrm{A}$ ' on the reactant side is $0.5000 \mathrm{E}-01$ 


$$
\begin{aligned}
& \mathrm{SR} 1 \mathrm{C} 1 \mathrm{O} 3+100 \mathrm{AL}+<\mathrm{A}>\mathrm{BI}= \\
& 0.00000 \mathrm{E}+00 \quad(0.11139 \mathrm{E}-03) \mathrm{St} \\
& \text { ( } 1273.0,1.00, G, 0.114 \mathrm{E}-03 \text { ) } \\
& +97.532
\end{aligned}
$$

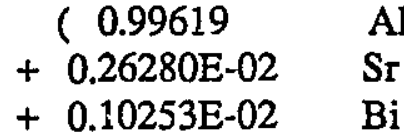

$$
\begin{aligned}
& +0.12598 \mathrm{E}-03 \quad \mathrm{Al} 2 \mathrm{O} 3 \\
& +\begin{array}{cc}
0.29710 \mathrm{E}-04 & \text { Sr } \\
(1273.0,1.00 & \text {,SOLN 2) }
\end{array} \\
& +0.74079 \quad \text { (SrO)(Al2O3) } \\
& (1273.0,1.00 \quad, \mathrm{~S} 2,1.0000) \\
& +0.33333 \quad \mathrm{Al} 4 \mathrm{C} 3 \\
& (1273.0,1.00 \quad, \mathrm{~S} 1,1.0000)
\end{aligned}
$$

where ' $\mathrm{A}$ ' on the reactant side is $0.1000 \mathrm{E}+00$

SR1C1O3+100AL $+<A>B I=$

$$
\begin{aligned}
& 0.00000 \mathrm{E}+00 \\
& \text { ( } 0.11133 \mathrm{E}-03 \quad \mathrm{Sr} \\
& (1273.0,1.00, \mathrm{G}, 0.115 \mathrm{E}-03) \\
& +97.582 \\
& \text { ( } 0.99568 \\
& +0.26267 \mathrm{E}-02 \quad \mathrm{Sr} \\
& +0.15371 \mathrm{E}-02 \quad \mathrm{Bi} \\
& +0.12599 \mathrm{E}-03 \quad \mathrm{Al} 2 \mathrm{O} 3 \mathrm{~T} \\
& +0.29695 \mathrm{E}-04 \quad \mathrm{Sr} \quad<--) \\
& \text { (1273.0, } 1.00 \text {,SOLN 2) } \\
& +0.74078 \quad(\mathrm{SrO})(\mathrm{Al} 2 \mathrm{O} 3) \\
& (1273.0,1.00 \quad, \mathrm{~S} 2,1.0000) \\
& +0.33333 \quad \mathrm{Al} 4 \mathrm{C} 3 \\
& (1273.0,1.00 \quad, \mathrm{~S} 1,1.0000)
\end{aligned}
$$

where ' $A$ ' on the reactant side is 0.1500

SR1C1O3+100AL+ $<A>B I=$

$0.00000 \mathrm{E}+00 \quad\left(\begin{array}{llll}0.11128 \mathrm{E}-03 & \mathrm{Sr} & \mathrm{T}\end{array}\right)$




$$
(1273.0,1.00, \mathrm{G}, 0.115 \mathrm{E}-03 \quad)
$$

$$
\begin{aligned}
& +97.632 \quad\left(\begin{array}{lll}
0.99517 & \mathrm{Al}
\end{array}\right. \\
& +0.26255 \mathrm{E}-02 \quad \mathrm{Sr} \\
& +0.20485 \mathrm{E}-02 \quad \mathrm{Bi} \\
& +0.12600 \mathrm{E}-03 \quad \mathrm{Al} 2 \mathrm{O} 3 \mathrm{~T} \\
& +0.29680 \mathrm{E}-04 \quad \mathrm{Sr}<--) \\
& \text { (1273.0, } 1.00 \text {,SOLN 2) } \\
& +0.74077 \quad(\mathrm{SrO})(\mathrm{Al} 2 \mathrm{O} 3) \\
& (1273.0,1.00 \quad, \text { S2, } 1.0000) \\
& +0.33333 \quad \mathrm{Al} 4 \mathrm{C} 3 \\
& (1273.0,1.00 \quad, S 1,1.0000)
\end{aligned}
$$

where ' $A$ ' on the reactant side is 0.2000

SR1C1O3+100AL $+<A>B I=$

$$
\begin{aligned}
& 0.00000 \mathrm{~F}+00 \\
& \text { ( } 0.11117 \mathrm{E}-03 \quad \mathrm{Sr} \\
& (1273.0,1.00, \mathrm{G}, 0.117 \mathrm{E}-03) \\
& +97.732
\end{aligned}
$$

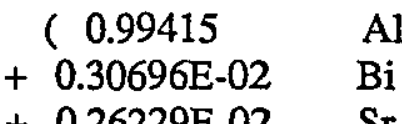

$$
\begin{aligned}
& +0.26229 \mathrm{E}-02 \mathrm{Sr} \\
& \begin{array}{ccc}
+0.12603 \mathrm{E}-03 & \mathrm{Al} 2 \mathrm{O} 3 & \mathrm{~T} \\
+0.29651 \mathrm{E}-04 & \mathrm{Sr} & <--) \\
(1273.0,1.00 & \text {,SOLN 2) } &
\end{array} \\
& +0.74076 \quad \text { (SrO)(Al2O3) } \\
& (1273.0,1.00 \quad, \mathrm{~S} 2,1.0000) \\
& +0.33333 \quad \mathrm{Al} 4 \mathrm{C} 3 \\
& \text { (1273.0, } 1.00 \quad, S 1,1.0000 \quad)
\end{aligned}
$$

where ' $A$ ' on the reactant side is 0.3000

$\mathrm{SR} 1 \mathrm{C} 103+100 \mathrm{AL}+\angle \mathrm{A}>\mathrm{BI}=$

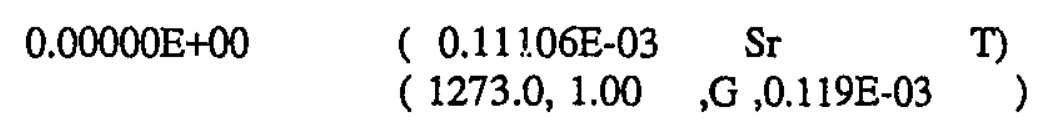




$$
\begin{aligned}
& +97.832 \quad\left(\begin{array}{lll}
0.99314 & \mathrm{Al}
\end{array}\right. \\
& +0.40886 \mathrm{E}-02 \quad \mathrm{Bi} \\
& +0.26203 \mathrm{E}-02 \quad \mathrm{Sr} \\
& +0.12606 \mathrm{E}-03 \text { Al2O3 T } \\
& +0.29622 \mathrm{E}-04 \quad \text { Sr }<---) \\
& \left.\begin{array}{ll}
0.74075 & (\mathrm{SrO})(\mathrm{Al} 2 \mathrm{O} 3) \\
(1273.0,1.00 & , \mathrm{S} 2,1.0000
\end{array}\right) \\
& +0.33333 \quad \mathrm{Al} 4 \mathrm{C} 3 \\
& (1273.0,1.00 \quad, S 1,1.0000)
\end{aligned}
$$

where ' $\mathrm{A}$ ' on the reactant side is 0.4000

\section{$\mathrm{SR} 1 \mathrm{ClO} 3+100 \mathrm{AL}+<\mathrm{A}>\mathrm{BI}=$}

$$
\begin{aligned}
& \begin{array}{llll}
0.00000 \mathrm{E}+00 & \left(\begin{array}{ccc}
0.11095 \mathrm{E}-03 & \mathrm{Sr} & \mathrm{T}
\end{array}\right) \\
& (1273.0,1.00, \mathrm{G}, 0.121 \mathrm{E}-03 &
\end{array} \\
& +97.932 \quad\left(\begin{array}{ll}
0.99212 & \mathrm{Al}
\end{array}\right. \\
& +0.51055 \mathrm{E}-02 \quad \mathrm{Bi} \\
& +0.26178 \mathrm{E}-02 \quad \mathrm{Sr} \\
& +0.12609 \mathrm{E}-03 \text { Al2O3 } \mathrm{T}
\end{aligned}
$$

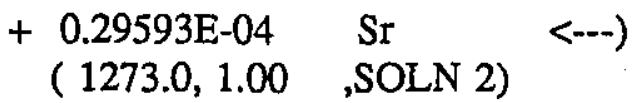

$$
\begin{aligned}
& +0.74074 \quad(\mathrm{SrO})(\mathrm{Al} 2 \mathrm{O} 3) \\
& (1273.0,1.00 \quad, S 2,1.0000) \\
& +0.33333 \quad \text { Al4C3 } \\
& \text { (1273.0, } 1.00 \quad, \mathrm{~S} 1,1.0000)
\end{aligned}
$$

where ' $\mathrm{A}$ ' on the reactant side is 0.5000

SR1C1O3+100AL $+\angle A>B I=$

$\left.\begin{array}{cccc}0.00000 \mathrm{E}+00 & (0.11085 \mathrm{E}-03 & \mathrm{Sr} & \mathrm{T} \\ & +0.11710 \mathrm{E}-04 & \mathrm{Bi}) & \\ & (1273.0,1.00, \mathrm{G}, 0.123 \mathrm{E}-03 \quad\end{array}\right)$




$$
\begin{aligned}
& +0.61204 \mathrm{E}-02 \quad \mathrm{Bi} \\
& +0.26152 \mathrm{E}-02 \quad \mathrm{Sr} \\
& +0.12612 \mathrm{E}-03 \quad \mathrm{Al} 2 \mathrm{O} 3 \mathrm{~T} \\
& +0.29565 \mathrm{E}-04 \text { Sr }<--) \\
& \text { ( } 1273.0,1.00 \text {,SOLN 2) } \\
& +0.74073 \quad(\mathrm{SrO})(\mathrm{Al} 2 \mathrm{O} 3) \\
& (1273.0,1.00 \quad, \mathrm{~S} 2,1.0000) \\
& +0.33333 \quad \mathrm{Al} 4 \mathrm{C} 3 \\
& (1273.0,1.00 \quad, S 1,1.0000)
\end{aligned}
$$

where ' $A$ ' on the reactant side is $0.60 \% 0$

$$
\begin{aligned}
& \text { SR1C1O3+100AL }+<A>B I= \\
& 0.00000 \mathrm{E}+00 \\
& \text { ( } 0.11074 \mathrm{E}-03 \quad \mathrm{Sr} \\
& +0.13648 \mathrm{E}-04 \quad \mathrm{Bi}) \\
& (1273.0,1.00, \mathrm{G}, 0.125 \mathrm{E}-03 \text { ) } \\
& +98.132
\end{aligned}
$$

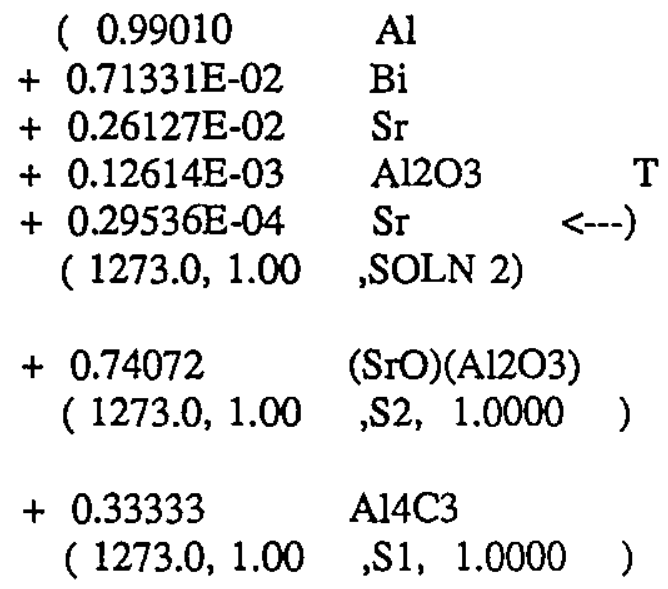

where ' $\mathrm{A}$ ' on the reactant side is 0.7000

$\mathrm{SR} 1 \mathrm{C1O} 3+100 \mathrm{AL}+<\mathrm{A}>\mathrm{BI}=$

$\left.\begin{array}{cccc}0.00000 \mathrm{E}+00 & (0.11063 \mathrm{E}-03 & \mathrm{Sr} & \mathrm{T} \\ & +0.15582 \mathrm{E}-04 & \mathrm{Bi}) & \\ & (1273.0,1.00 & , \mathrm{G}, 0.127 \mathrm{E}-03\end{array}\right)$




$$
\begin{aligned}
& +0.81439 \mathrm{E}-02 \quad \mathrm{Bi} \\
& +0.26101 \mathrm{E}-02 \text { Sr } \\
& +0.12617 \mathrm{E}-03 \quad \mathrm{Al} 2 \mathrm{O} 3 \mathrm{~T} \\
& +0.29507 \mathrm{E}-04 \text { Sr <---) } \\
& \text { (1273.0, } 1.00 \text {,SOLN 2) } \\
& +0.74070 \quad \text { (SrO)(Al2O3) } \\
& (1273.0,1.00 \text {,S2, } 1.0000 \text {; } \\
& +0.33333 \quad \mathrm{Al} 4 \mathrm{C} 3 \\
& (1273.0,1.00 \quad, \mathrm{~S} 1,1.0000)
\end{aligned}
$$

where ' $\mathrm{A}$ ' on the reactant side is 0.8000

$\mathrm{SR} 1 \mathrm{C} 103+100 \mathrm{AL}+\angle \mathrm{A}>\mathrm{BI}=$

$$
\begin{aligned}
& 0.00000 \mathrm{E}+00 \\
& \text { ( } 0.11052 \mathrm{E}-03 \quad \mathrm{Sr} \\
& +0.17511 \mathrm{E}-04 \quad \mathrm{Bi}) \\
& \text { (1273.0, } 1.00 \text {,G ,0.128E-03 ) } \\
& +98.332
\end{aligned}
$$

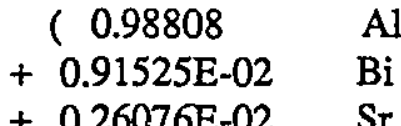

$$
\begin{aligned}
& +0.12620 \mathrm{E}-03 \quad \mathrm{~A} 12 \mathrm{O} 3 \\
& \begin{array}{rll}
+ & 0.12620 \mathrm{E}-03 & \mathrm{Al} 2 \mathrm{O} 3 \\
+0.29478 \mathrm{E}-04 & \mathrm{Sr} & \mathrm{T} \\
(1273.0,1.00 & , \mathrm{SOLN} 2)
\end{array} \\
& +0.74069 \quad \text { (SrO)(Al2O3) } \\
& (1273.0,1.00 \quad, S 2,1.0000) \\
& +0.33333 \quad \mathrm{Al} 4 \mathrm{C} 3 \\
& (1273.0,1.00 \quad, S 1,1.0000)
\end{aligned}
$$

where ' $A$ ' on the reactant side is 0.9000

$\mathrm{SRIC1O} 3+100 \mathrm{AL}+<\mathrm{A}>\mathrm{BI}=$

$\left.\begin{array}{cccc}0.00000 \mathrm{E}+00 & (0.11041 \mathrm{E}-03 & \mathrm{Sr} & \mathrm{T} \\ & +0.19437 \mathrm{E}-04 & \mathrm{Bi}) & \\ & (1273.0,1.00, \mathrm{G}, 0.130 \mathrm{E}-03 \quad\end{array}\right)$




$$
\begin{aligned}
& +0.10159 \mathrm{E}-01 \quad \mathrm{Bi} \\
& +0.26050 \mathrm{E}-02 \quad \mathrm{Sr} \\
& +0.12623 \mathrm{E}-03 \quad \mathrm{Al} 2 \mathrm{O} 3 \quad \mathrm{~T} \\
& +0.29450 \mathrm{E}-04 \quad \mathrm{Sr} \quad<---) \\
& \text { (1273.0, } 1.00 \text {,SOLN 2) } \\
& +0.74068 \quad(\mathrm{SrO})(\mathrm{Al} 2 \mathrm{O} 3) \\
& (1273.0,1.00 \quad, \mathrm{~S} 2,1.0000) \\
& +0.33333 \quad \mathrm{Al} 4 \mathrm{C} 3 \\
& \text { (1273.0, } 1.00 \text {,S1, } 1.0000 \text { ) }
\end{aligned}
$$

where ' $\mathrm{A}$ ' on the reactant side is 1.000 


\section{APPENDIX B}

This study dealt with four major metallic species, aluminum, magnesium, bismuth and strontium. Figures B.1 to B.6 show the ternary phase diagram for Al-Mg-Sr and the binary phase diagrams for $\mathrm{Al}-\mathrm{Mg}, \mathrm{Al}-\mathrm{Sr}, \mathrm{Mg}-\mathrm{Sr}, \mathrm{Al}-\mathrm{Bi}$, and $\mathrm{Bi}-\mathrm{Sr}$. There was no evidence of ternary phase diagram for $\mathrm{Al}-\mathrm{Bi}-\mathrm{Sr}$. It can be observed that no precipitation of intermetallics species would occur at the weight percents incurred and at the temperature of $1000^{\circ} \mathrm{C}$.

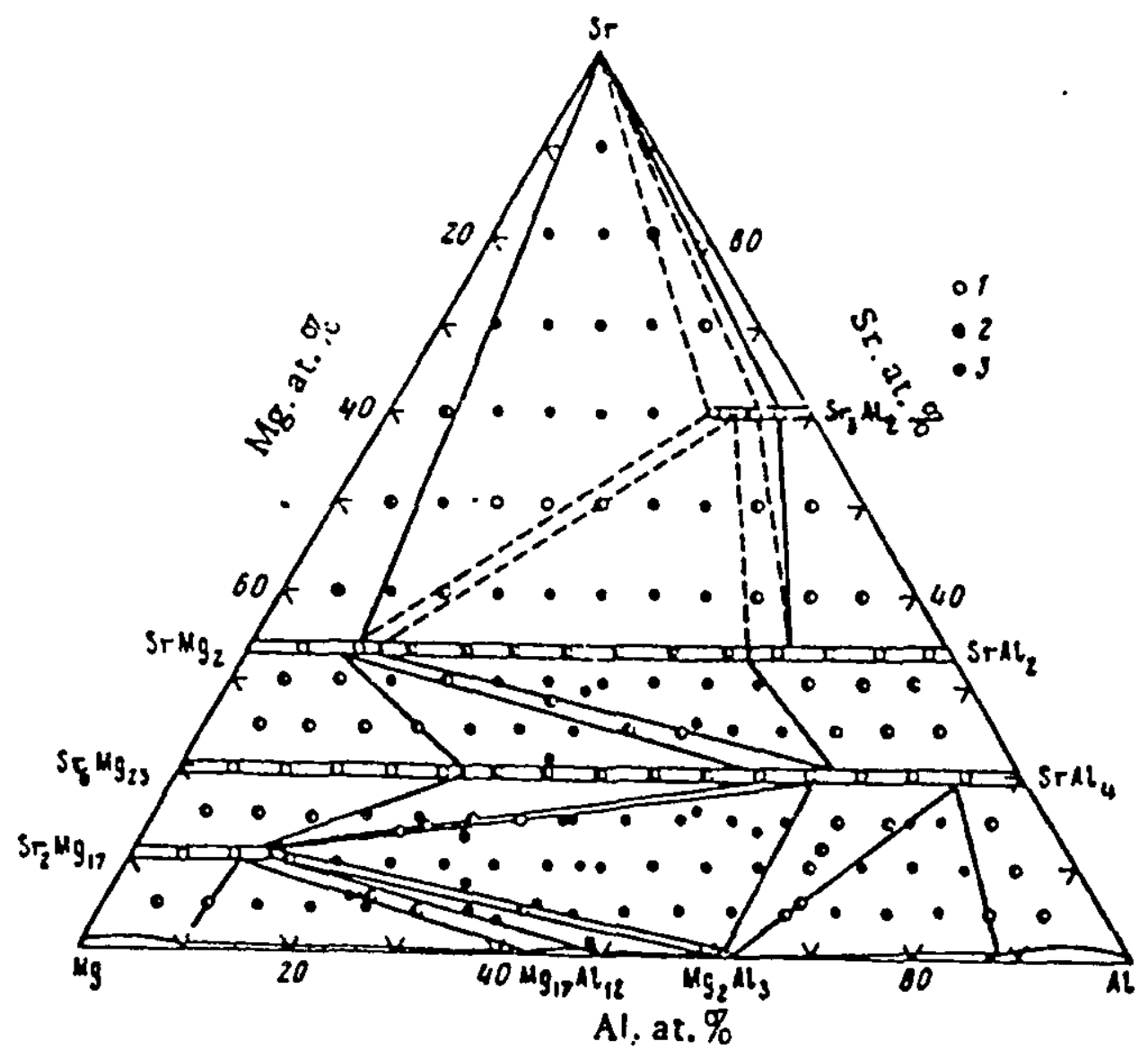

Figure B.1 Phase diagram of Al-Mg-Sr Alloys at $673 \mathrm{~K}^{(58)}$

1- Single-phase; 2- two-phase; 3- three-phase 


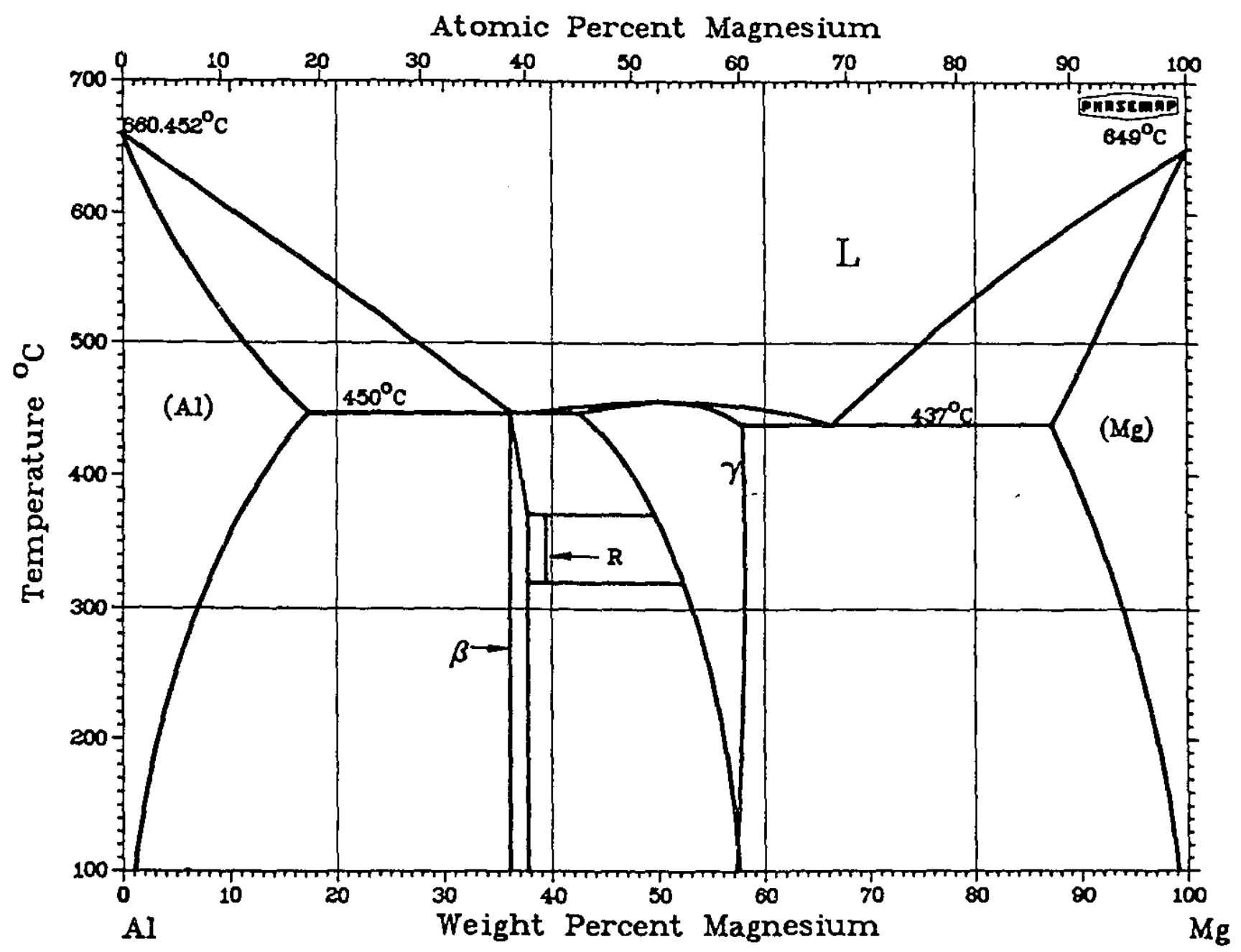

Figure B.2 Al-Mg Binary Phase Diagram ${ }^{(59)}$ 


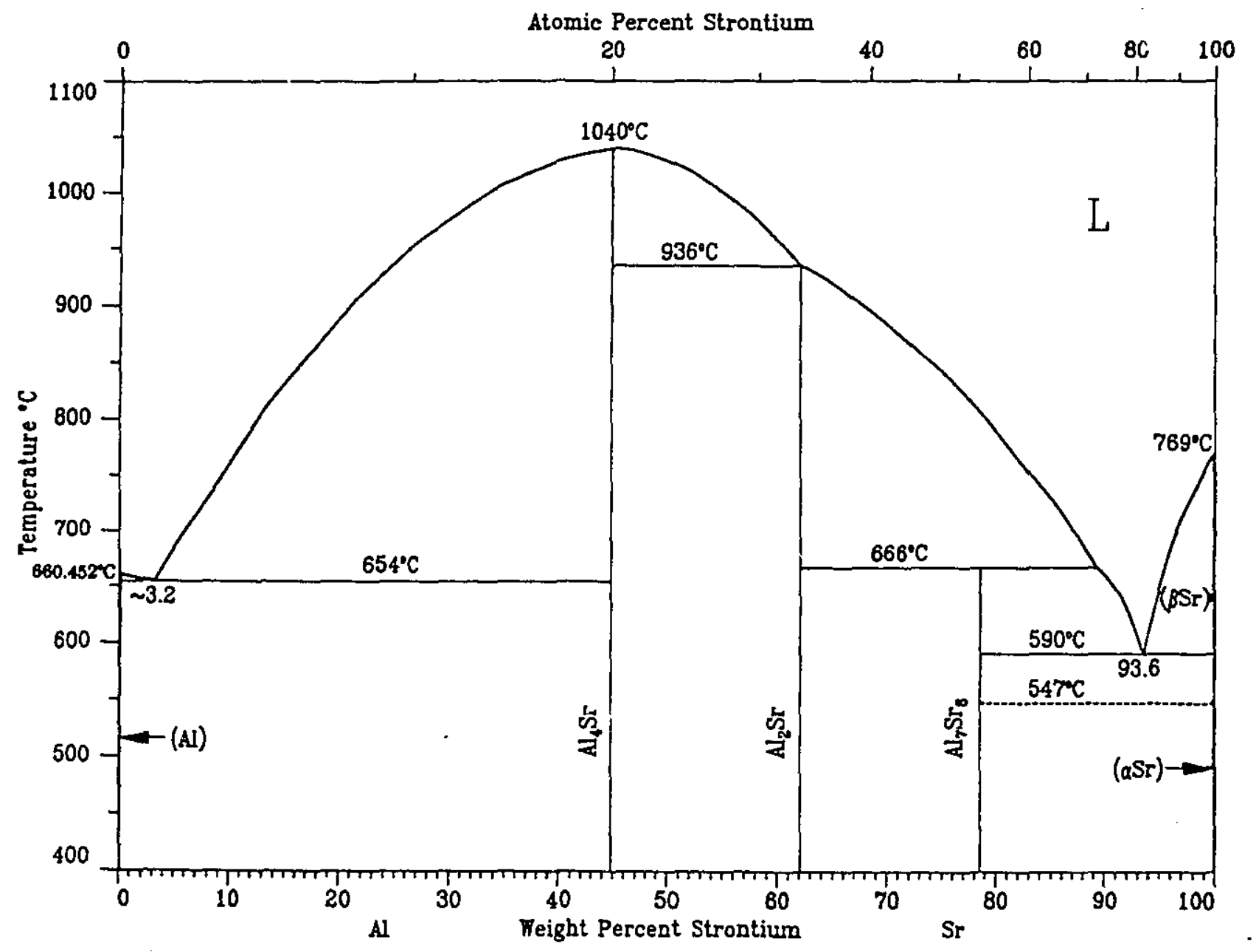

Figure B.3 Al-Sr Binary Phase Diagram ${ }^{(60)}$ 


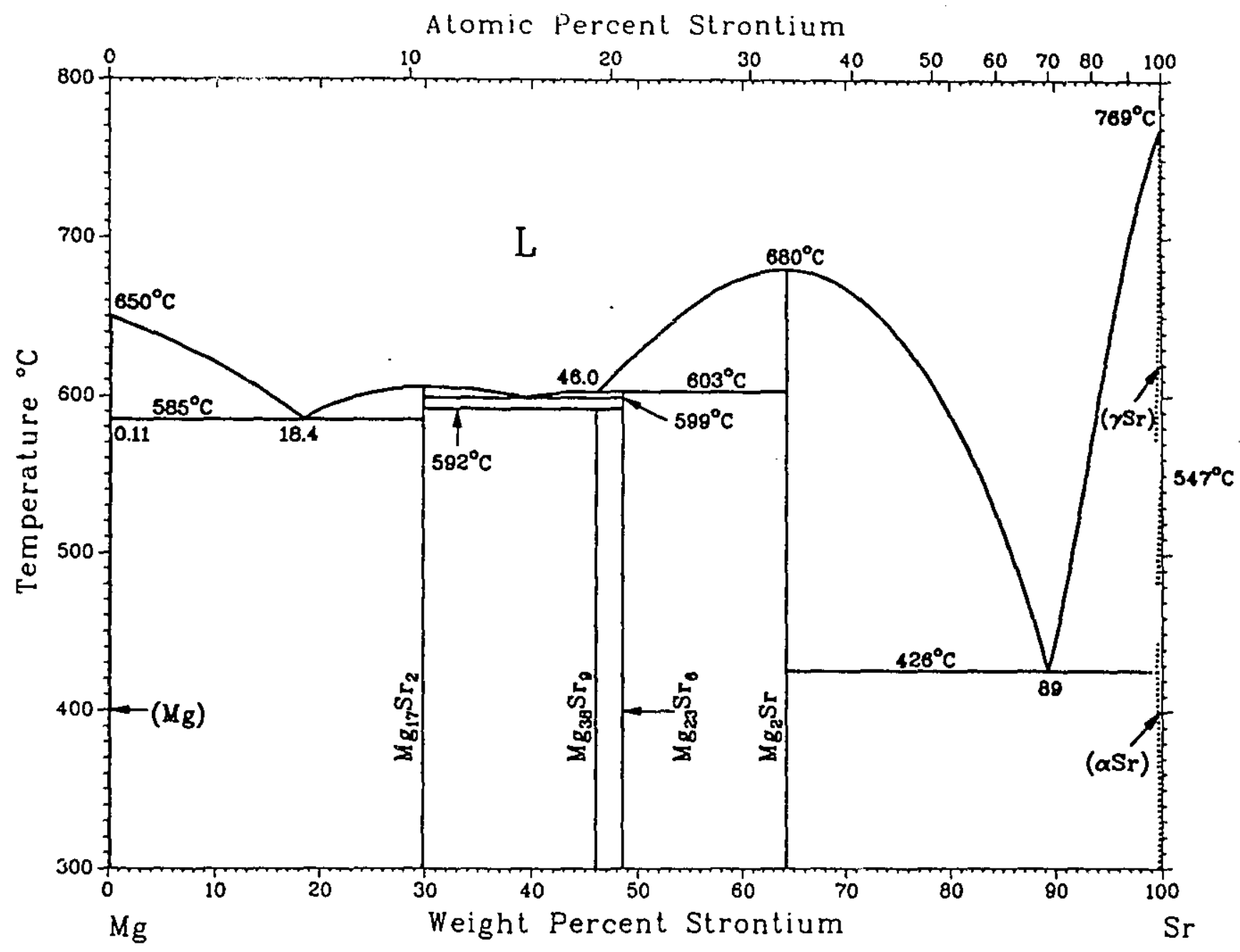

Figure B.4 Mg-Sr Binary Phase Diagram ${ }^{(61)}$ 


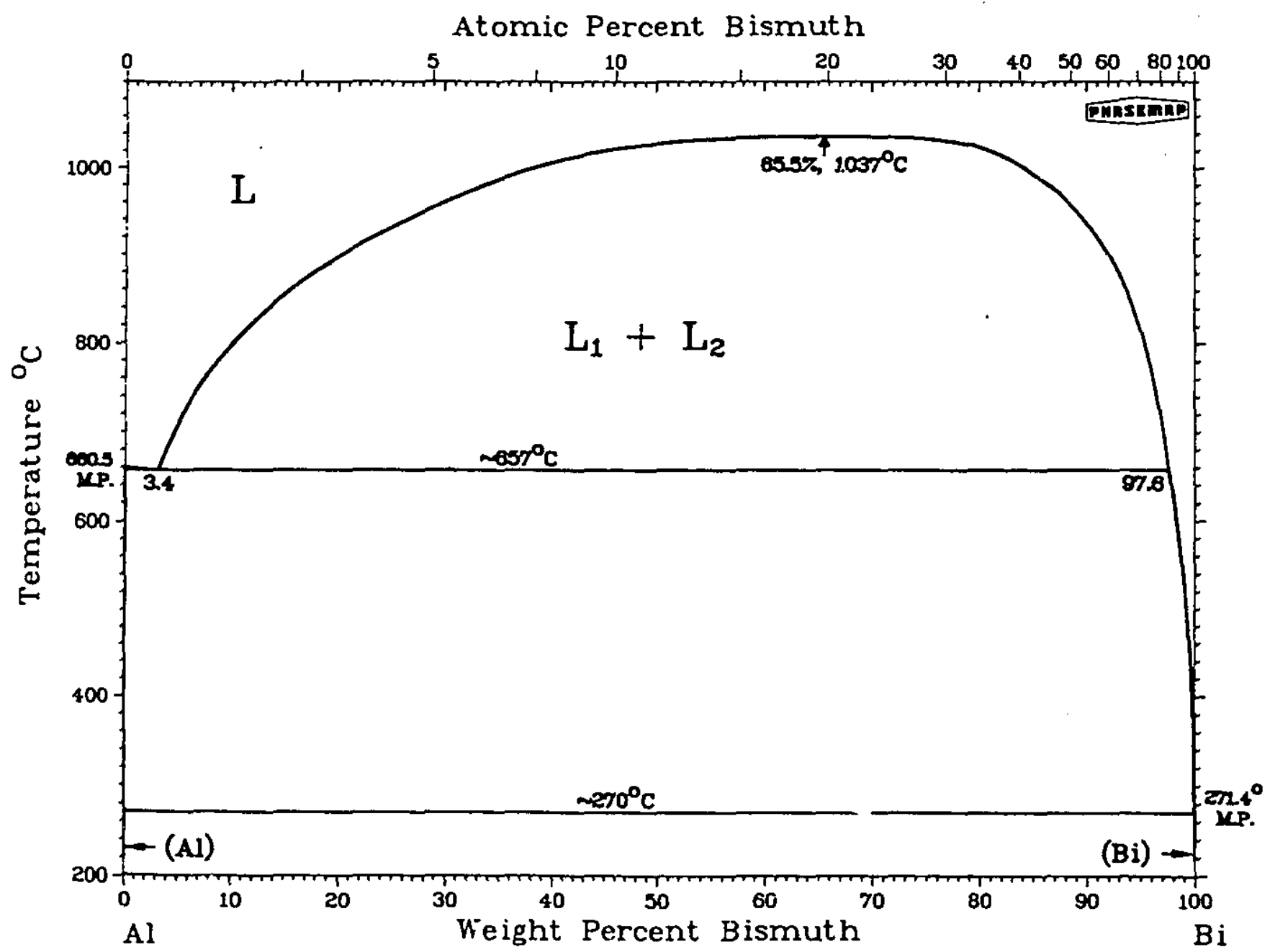

Figure B.5 Al-Bi Binary Phase Diagram ${ }^{(62)}$ 


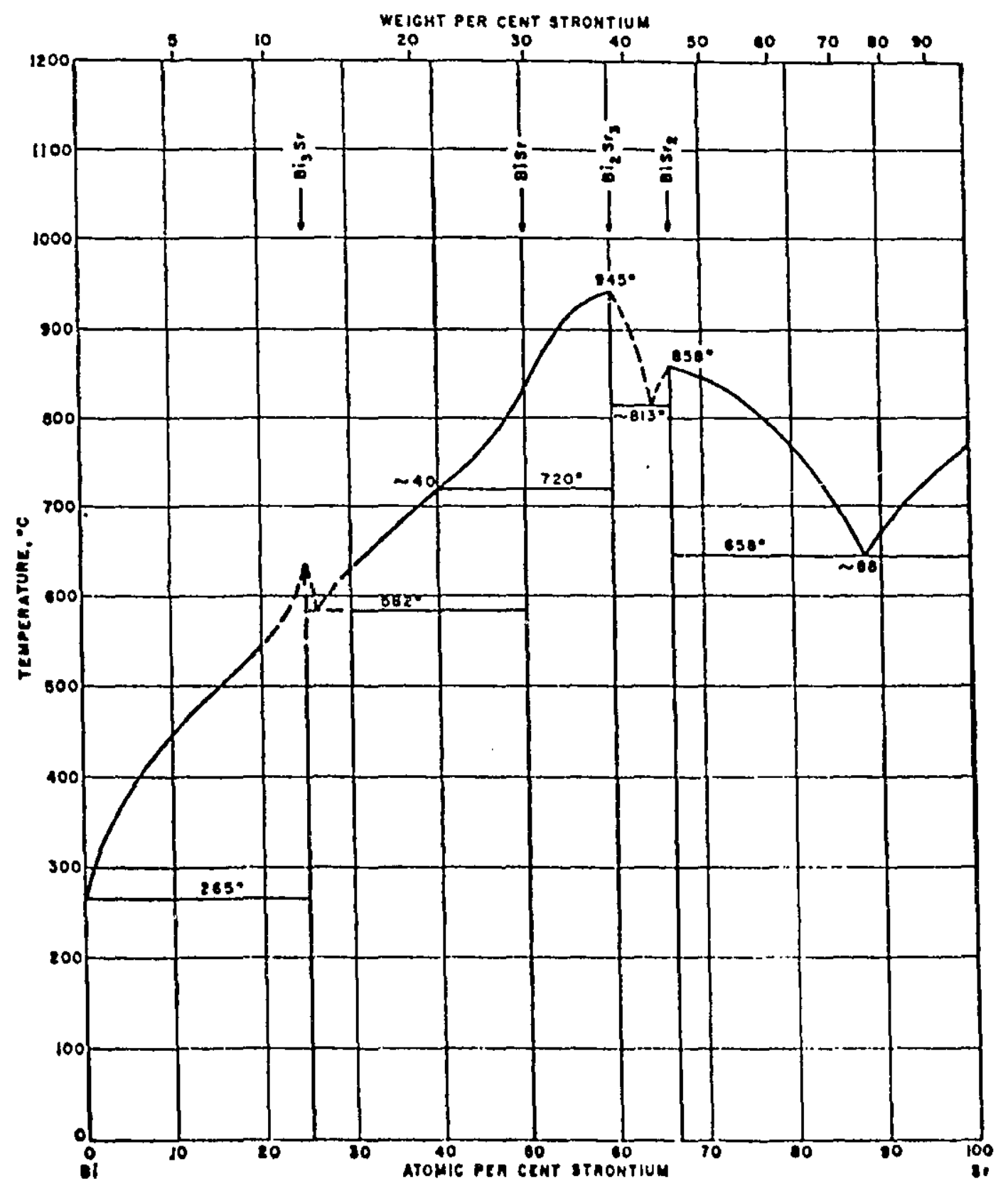

Figure B.6 Bi-Sr Binary Phase Diagram ${ }^{(63)}$ 